FELIPE MARTINS DOS SANTOS

\title{
Possiveis efeitos antineoplásicos e mieloprotetores da Ipomoea carnea e de seu princípio ativo, a suainsonina, em camundongos
}




\section{FELIPE MARTINS DOS SANTOS}

\section{Possíveis efeitos antineoplásicos e mieloprotetores da Ipomoea carnea e de seu princípio ativo, a suainsonina, em camundongos}

Dissertação apresentada ao Programa de Pós-Graduação em Patologia Experimental e Comparada da Faculdade de Medicina Veterinária e Zootecnia da Universidade de São Paulo para obtenção do título de Mestre em Ciências

\section{Departamento:}

Patologia

Área de concentração:

Patologia Experimental e Comparada

\section{Orientadora:}

Profa. Dra. Helenice de Souza Spinosa 
Autorizo a reprodução parcial ou total desta obra, para fins acadêmicos, desde que citada a fonte.

DADOS INTERNACIONAIS DE CATALOGAÇÃO-NA-PUBLICAÇÃO

(Biblioteca Virginie Buff D’Ápice da Faculdade de Medicina Veterinária e Zootecnia da Universidade de São Paulo)

T.2165 Santos, Felipe Martins dos

Possíveis efeitos antineoplásicos e mieloprotetores da Ipomoea carnea e de seu princípio ativo, a suainsonina, em camundongos / Felipe Martins dos Santos. - São Paulo : F. M. Santos, 2009.

$185 \mathrm{f}$. : il.

Dissertação (mestrado) - Universidade de São Paulo. Faculdade de Medicina Veterinária e Zootecnia. Departamento de Patologia, 2009.

Programa de Pós-Graduação: Patologia Experimental e Comparada.

Área de concentração: Patologia Experimental e Comparada.

Orientador: Profa. Dra. Helenice de Souza Spinosa.

1. Ipomoea cárnea. 2. Neoplasias. 3. Medula óssea. 4. Tumor de Ehrlich. 5. Camundongo. I. Título. 


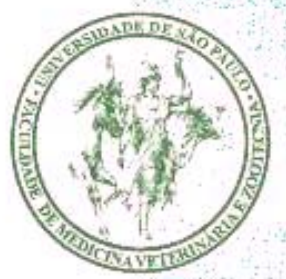

\section{UNIVERSIDADE DE SÃO PAULO \\ Faculdade de Medicina Veterinária e Zootecnia}

Comissão Bioética

\section{CERTIFICADO}

Certificamos que o Projeto intitulado "Avaliação dos possíveis efeitos antineoplástico e antimetastáticos da Ipomoea carnea e do seu princípio ativo, suainsonina em camundongos", protocolado sob o ${ }^{\circ} 1161 / 2007$, utilizando 80 (oitenta) camundongos, sob responsabilidade da Profa. Dra. Helenice de Souza Spinosa, está de acordo com os princípios éticos de experimentação animal da Comissão de Bioética da Faculdade de Medicina Veterinária e Zootecnia da Universidade de São Paulo e foi aprovado em reunião de 22/08/07.

(We certify that the Research "Evaluation of possible antineoplasic and antimetastatix effects of Ipomoea carnea and the active principle swainsonine in mice", protocol number 1161/2007, utilizing 80 (eighty) mice, under the responsibility Profa. Dra. Helenice de Souza Spinosa, agree with Ethical Principles in Animal Research adopted by Bioethic Commission of the School of Veterinary Medicine and Zootechny of University of São Paulo and was approved in the meeting of day $08 / 22 / 07$.

São Paulo, 22 de agosto de 2007

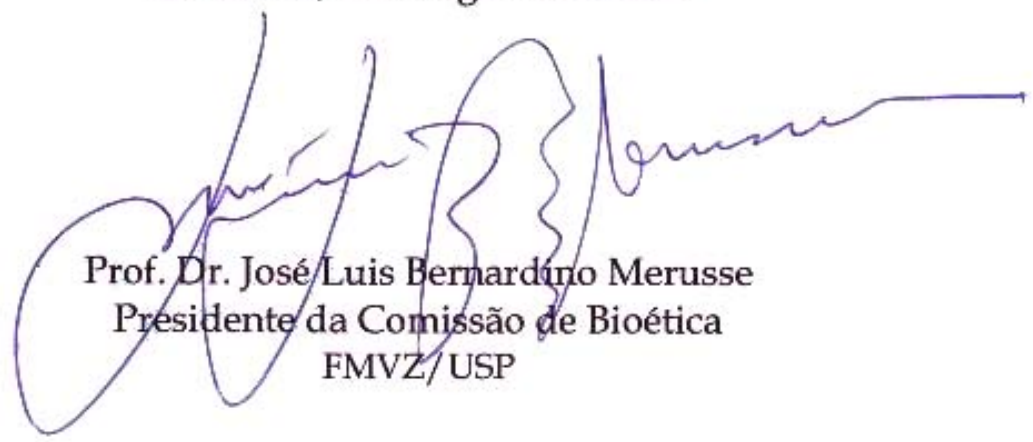

Av. Prof. Dr. Orlando Marques de Paiva, n 87 - 05508-270 - Cidade Universitária "Armando de Salles Oliveira". Fax: (11) 3032-2224 - fones: (11) 309107676/7671 - e-mail: fmvz@edu.usp.br 


\section{FOLHA DE AVALIAÇÃO}

Nome: SANTOS, Felipe Martins dos

Título: Possíveis efeitos antineoplásicos e mieloprotetores da Ipomoea carnea e de seu princípio ativo, a suainsonina, em camundongos

Dissertação apresentada ao Programa de PósGraduação em Patologia Experimental e Comparada da Faculdade de Medicina Veterinária e Zootecnia da Universidade de São Paulo para obtenção do título de Mestre em Ciências

Data:

\section{Banca Examinadora}

Prof. Dr.

Assinatura:

Prof. Dr.

Assinatura:

Prof. Dr.

Assinatura:
Instituição:

Julgamento:

Instituição:

Julgamento:

Instituição:

Julgamento: 
Esta dissertação foi realizada no Laboratório de Farmacologia Aplicada $e$ Toxicologia do Departamento de Patologia da Faculdade de Medicina Veterinária e Zootecnia da Universidade de São Paulo, com bolsa de mestrado concedida pela Fundação de Amparo à Pesquisa do Estado de São Paulo (FAPESP), Processo $n^{\circ}$. $07 / 52117-8$ 
"I have a dream that my four little children will one day live in a nation where they will not be judged by the color of their skin, but by the content of their character."

Martin Luther King, Jr.

28 de agosto de 1963

"Yes we can."

Barack Hussein Obama II

20 de janeiro de 2009

Sem apologias aos Estados Unidos 


\section{Agradecimentos}

Aos meus pais Sueli e Ari, pelo amor, paciência, apoio, fé, carinho e compreensão em todos os momentos da realização deste trabalho, principalmente durante os últimos meses. Preço desculpas por todos os dias em que me ausentei, e de maneira mais enfática peço desculpas por todas as vezes que fui impaciente e ríspido.

À minha irmã Raquel por estreitar os nossos lados fraternos a cada ano.

Ao meu irmão Thiago por tentar me ensinar algo que ainda não consigo aprender.

À minha orientadora Profa. Dra. Helenice de Souza Spinosa, pelos conhecimentos transmitidos, pela amizade, confiança, paciência, apoio e exemplo. E principalmente por ser transparente, calma, compreensiva e por todo apoio que forneceu para o meu crescimento profissional. Obrigado!

À Dra. Isis Machado Hueza pelos conhecimentos, amizade sincera, confiança, paciência, apoio. Pelas boas idéias, por toda ajuda com as análises dos meus resultados, e principalmente nos meus relatórios FAPESP. Gostaria de te dizer que você foi responsável por dar firmeza aos meus primeiros passos na pós-graduação.

À Andréia Latorre e Heidge Fukumasu. À Andréia por ser um exemplo de pósgraduanda, competente, disposta, comprometida, brilhante, etc, etc, etc. Gostaria de elogiar ainda, sua disposição em ajudar, dar boas idéias, discutir resultados, gráficos, dados, protocolos, etc, etc, etc. Além disso, é uma amiga muito carinhosa. Ao Heidge por todo o suporte dado durante o mestrado, principalmente no começo. Obrigado! 
Aos colegas Daniel Soares Sanches e Carolina Gonçalves Pires por toda ajuda desprendida em minhas laminas histológicas. Pelas dicas, ensinamentos e especialmente pela disposição em me ajudar.

À Profa. Dra. Lílian Rose Marques de Sá do Departamento de Patologia (VPT) da FMVZ-USP, pelos ensinamentos transmitidos e por toda paciência e tempo dispensado na análise histopatológica. Aos professores João Palermo Neto e Luiz Carlos de Sá Rocha, por permitirem a utilização do citômetro de fluxo. Aos demais professores do VPT, especialmente Jorge Camilo Flório, Paulo César Maiorka, Maria Lúcia Zaidan Dagli e Silvana Lima Górniak pelas idéias e pelo auxílio quando necessário.

À Luciana Lippi... O que poderia dizer de uma pessoa tão especial? A Lu é mais do que uma colega, é uma amiga fantástica! Sempre pronta para ajudar, foi uma das pessoas mais comprometidas com o meu trabalho, sempre esteve presente nos meus experimentos, do começo ao fim, em todos os dias intermináveis. Foi fundamental para a realização deste trabalho, não só pela ajuda intelectual ou pela "mão de obra barata", mas principalmente pela alegria que sempre trouxe ao ambiente, pelas boas risadas, e músicas de péssima qualidade... Obrigado!

À Camila Lima (Camilinha) por dividir comigo bons momentos, pelas risadas, conversas, congressos, festas, etc. Por toda força dada durante a fase do concurso, pelas conversas filosóficas (não importa qual a teoria discutida) e pelos laços de amizade! 
Aos colegas Wanderley e Silvia por dividirem comigo momentos únicos durante todo - mestrado, pelas risadas, conversas de corredor, congressos, etc. E principalmente pela amizade confiada!

À Fabiana Xavier, por ter sido a primeira pessoa que acreditou no meu potencial, por ter me dado todo apoio e estímulo durante toda a fase inicial do mestrado, ter me apresentado para professora Helenice. E principalmente por ter me apresentado a Camila....

Aos amigos de faculdade Cleber, Marcio, Carolinne, Huber, Otávio, Fernanda, Juliana, Bruno e Debora. Por terem me apoiado durante todo o mestrado, de maneira especial durante o começo que, sem dúvida, foi extremante difícil. Por serem amigos sempre presentes, mesmo longe. Valeu!

Aos companheiros de OUTBACK Ana Helena, Guto, Fabi, Marcio (!?!), Fred, Dani, Claudia, e principalmente Marinózes. Por toda amizade e confidência, por terem me ajudado muito durante uma fase difícil.

Pelos "parceiros" da Policia Técnico-Científica Felipe, Caio, Guilherme, Andrézinho, Alexandre, Vicent, Antonio, José Roberto, Alisson, André, Ana, Érica, Priscila, e Carla. Por estarem do meu lado nesta nova etapa da minha vida, por acreditarem em um futuro melhor e justo, e principalmente por me sustentarem nestes meses "prédissertação". 
Aos demais familiares, avós, primos, tios e tias, por sempre acreditarem mais em mim do que eu mesmo. À Maria Amélia, Virgilio e Conrado por me "emprestarem" a Camila Obrigado.

Aos colegas de república Luciana Cunha, Alisson, Viviane, e Karen, por terem dividido o teto comigo, as contas e as "condições precárias de higiene", pelas risadas e boa convivência "familiar".

Aos funcionários do biotério do VPT Claudia, Herculano, Mauro, Nelson e Rosiris, pelos cuidados dispensados aos animais utilizados nos experimentos, por todo auxílio e ótima convivência. Principalmente à Dona Idalina, por inundar o biotério com charme, beleza e sensualidade, e especialmente por me descontrair durante os dias de experimento. Te adoro!

Aos técnicos do Laboratório de Farmacologia Aplicada e Toxicologia do VPT Ricardo e Magali, pela paciência, auxílio nos experimentos e amizade. Principalmente à Priscila, pela competência, por sempre ser prestativa, pela amizade e pelo carinho.

Às secretárias do VPT, da pós-graduação da FMVZ e da pós-graduação do VPT Cláudia, Cristina, Cláudia, Deise, Joana e Sílvia, pelo auxílio sempre que preciso.

A todas as "meninas" e "meninos" da biblioteca da FMVZ, pelo auxílio sempre que necessário.

Aos colegas da pós-graduação do VPT: Alexandre, Aline, Altamir, Beatriz, Camila Lima, Daniel Cohn, Denise, Dudu, Domênica (obrigado por toda ajuda com as 
medulas!), Fernando, Karin, Lucas, Luciana Vismari, Milena, Mônica, Ricardo Garé, Ricardo Lazzarini, Thiago (obrigado por me deprimir com sua pontualidade!).

Ao Leo e a Lola, pelas noites mal-dormidas, pelas correrias pelo meio da sala, quarto, cozinha, banheiro, etc, etc. Por tornar nossa casa um ambiente mais feliz e principalmente mais peludo.

E a todos aqueles que, apesar de não terem sido mencionados individualmente, contribuíram para a realização deste trabalho, materialmente

A todos os animais usados nestes experimentos. 


\begin{abstract}
À minha "quase" esposa Camila... Não posso deixar de agradecer por todo o apoio que você me deu durante o mestrado, de maneira mais relevante na parte final... Obrigado por ter agüentado o meu mau-humor, ter lido meu trabalho umas 20.000 vezes. Não sei se teria conseguido sem você (e sem o seu lap top!rs).

Por tornar minha vida uma aventura! Por não me deixar ter um dia igual ao outro. Pelos sorrisos, carinhos, abraços e beijos. Pelos bons momentos divididos. Por dividir comigo seus excelentes hábitos alimentares (com direito a muito cachorro quente $e$ pizza). Por acreditar no meu potencial. Pelo convívio que tem com a minha família e por fazer questão que eu participe de sua família.

Por ser uma guerreira, lutar por tudo o que acredita!

E principalmente por querer viver comigo um sonho, correr todos os riscos que uma vida a dois pode ter... Por acreditar que seremos felizes! Por imaginar cada conquista que teremos, cada vitória, cada alegria. Espero ser o melhor marido do mundo. Te amo!
\end{abstract}




\section{RESUMO}

SANTOS, F. M. Possíveis efeitos antineoplásicos e mieloprotetores da Ipomoea carnea e de seu princípio ativo, a suainsonina, em camundongos. [Possible antineoplastic and mieloprotective effects of Ipomoea carnea and its active principle swainsonine in mice] 2009. 185 f. Dissertação (Mestrado em Ciências) Faculdade de Medicina Veterinária e Zootecnia, Universidade de São Paulo, São Paulo, 2009.

A Ipomoea carnea é uma planta tóxica de distribuição nacional e encontrada também em outros países de clima tropical. Possui entre seus princípios ativos um alcalóide indolizidínico chamado suainsonina que, devido à sua ação sobre enzimas intracelulares (a a-manosidase ácida e a manosidase II do Complexo de Golgi), altera receptores de membrana e moléculas de adesão. Acredita-se que a suainsonina possa ter atividades imunomodulatória, mieloprotetora, antineoplásica e antimetastática. Devido ao potencial terapêutico sugerido pela literatura, nesse estudo avaliou-se os possíveis efeitos antineoplásico e mieloprotetor da suainsonina empregada isoladamente ou em associação com um antineoplásico clássico, a cisplatina. Além disso, procurou-se avaliar se a administração do resíduo aquoso final da Ipomoea carnea (RAF), isoladamente ou também associado à cisplatina, possui atividade anitineoplásica. Foram utilizados camundongos C57BI/6, que foram inoculados por via intraperitoneal (ip.) com $2 \times 10^{7}$ células do tumor ascítico de Ehrlich. Os animais foram divididos nos grupos: BRANCO, CONTROLE e tratados com: cisplatina (CIS); cisplatina e suainsonina (CISSW); suainsonina (SW); cisplatina e RAF (CISRAF); e RAF (RAF). A suainsonina foi administrada por via ip. $2 x$ ao dia ( $1 \mathrm{mg} / \mathrm{kg}$ de peso vivo). A cisplatina foi administrada por via ip. em dias alternados $(0,25 \mathrm{mg} / \mathrm{kg})$. A administração do RAF foi realizada por gavage, na dose de $3 \mathrm{~g}$ de folhas secas $/ \mathrm{kg}$ de $\mathrm{I}$. carnea. Foi avaliada a sobrevida, o crescimento tumoral e a celularidade da medula óssea e do baço. Os resultados mostraram que apenas o grupo CISSW apresentou aumento significativo na sobrevida em relação ao grupo CONTROLE (Logrank test, $p<0,05)$. Em relação ao crescimento tumoral, os grupos CIS e CISSW apresentaram diminuições significantes quanto 
comparados ao grupo CONTROLE; porém, o grupo CISSW apresentou melhores resultados (ANOVA com pós teste de Dunn's, $p<0,001$ ) quando comparado ao grupo CONTROLE,enquanto os animais tratados com o RAF não apresentaram diferenças significantes. Dados sobre o ciclo celular (citometria de fluxo) revelaram que todos os animais tratados com a cisplatina (CIS, CISSW e CISRAF) apresentaram aumento significante no número de células tumorais em apoptose, porém o grupo CISSW apresentou melhores resultados, prejudicando de maneira mais eficiente o ciclo celular das células tumorais. As análises referentes à atividade mieloprotetora da suainsonina não apresentou dados relevantes. Estes dados em conjunto indicam efeito antineoplásico sinérgico da suainsonina quando administrada concomitantemente com a cisplatina.

Palavras-chave: Ipomoea carnea, Neoplasias, Medula óssea, Tumor de Ehrlich, Camundongo 


\begin{abstract}
SANTOS, F. M. Possible antineoplastic and mieloprotective effects of Ipomoea carnea and its active principle swainsonine in mice [Possíveis efeitos antineoplásicos e mieloprotetores da Ipomoea carnea e de seu princípio ativo, a suainsonina, em camundongos.]. 2009. 185 f. Dissertação (Mestrado em Ciências) Faculdade de Medicina Veterinária e Zootecnia, Universidade de São Paulo, São Paulo, 2009.
\end{abstract}

Ipomoea carnea is a toxic plant widely distributed in Brazil and other tropical countries. Among its active principles $I$. carnea has the indolizidine alkaloid swainsonine, which inhibits intracellular enzymes (the lysosomal a-mannosidase and the Golgi mannosidase II) and alters membrane receptors and adhesion molecules. It is known that swainsonine presents the following activities: imunommodulatory, bone marrow protective, antineoplastic e antimetastatic. Due to the therapeutical potencial suggested by other authors, the present study was performed to evaluate the antineoplastic and bone marrow protective effects of swainsonine when used alone or in association with a classic chemotherapy agent like cisplatin. Moreover, the antineoplastic effect of the $I$. carnea aqueous fraction (AF), when administered alone or in association with cisplatin, was evaluated. For this, male C57BI/6 mice were randomly assigned to seven groups: UNTREATED; CONTROL; CIS (treated with cisplatin); CIS-SW (treated with cisplatin and swainsonine); SW (treated with swainsonine); CIS-AF (treated with cisplatin and I. carnea aqueous fraction); and AF (treated only with $I$. carnea aqueous fraction). All animals except for those from the untreated group received an intraperitoneal (ip.) inoculation of $2 \times 10^{7}$ viable Ehrlich Ascites Carcinoma cells on day zero. Swainsonine was administered by the ip. route twice a day $(1 \mathrm{mg} / \mathrm{kg}$ of body weight), cisplatin was administered by the ip. route in alternate days $(0.25 \mathrm{mg} / \mathrm{kg}$ ) and AF (3g of $I$. carnea dry leaves $/ \mathrm{kg}$ ) was administered by the oral route (gavage). Survival rate, tumor growth, bone marrow and spleen cellularity were evaluated. The only group that showed a significant increase on the survival rate when compared to CONTROL was CISSW (Logrank test, $p<0.05$ ). 
Considering tumor growth, both CIS e CISSW groups showed significant decreases in this parameter when compared to CONTROL. However, this decrease was better observed in the CISSW group (ANOVA followed by Dunn's test, $p<0,001$ ), when compared to the CONTROL. Treatment with AF did not cause significant differences. The cell cycle results (flow citometry) revealed a significant increase in the number of apoptotic tumor cells in all animals treated with cisplatin (CIS, CISSW e CISRAF), although CISSW showed better results, altering the cycle of the tumor cells more efficiently. Swainsonine did not present any relevant protective activity on the bone marrow. These results suggest the existence of a synergism when swainsonine is administered in association with cisplatin.

Key-words: Ipomoea carnea, Neoplasia, Bone marrow, Ehrlich Tumor, Mice 


\section{LISTA DE TABELAS}

Proporção (em $\mathrm{mg} / \mathrm{kg} / \mathrm{dia}$ ) dos princípios ativos encontrados na

Tabela 1 - dose de $3 \mathrm{~g}$ de folha seca/kg do resíduo aquoso final da Ipomoea cárnea administrado aos camundongos.

Contagem total de células da medula óssea de camundongos que

Tabela 2 - receberam 0,$5 ; 1,0$ ou $1,5 \mathrm{mg} / \mathrm{kg}$ de cisplatina, nos dias experimentais 2, 4, 6, 8 e 10.

Tabela 3 - Valores de hematócrito de camundongos tratados com 0,5; 1,0 e $1,5 \mathrm{mg} / \mathrm{kg}$ de cisplatina, nos dias experimentais $2,4,6$, 8 e 10 .

Tabela 4 - Peso e volume tumoral de camundongos tratados com 0,5; 1,0 e $1,5 \mathrm{mg} / \mathrm{kg}$ de cisplatina, nos dias experimentais $2,4,6$, 8 e 10

Celularidade de medula óssea de camundongos C57BL/6

Tabela 5 - inoculados com tumor ascítico de Ehrlich e tratados e tratados com 1,0; 2,0 e 3,0mg/kg de cisplatina, nos dias 2, 4, 6, 8 e 10.

Volume, número total de células tumorais e número de células Tabela 6 - tumorais por $\mathrm{mL}$ de camundongos inoculados com tumor ascítico de Ehrlich e tratados com 1,0; 2,0 e 3,0mg/kg de cisplatina, nos dias 2, $4,6,8$ e 10

Celularidade de medula óssea de camundongos C57BL/6

Tabela 7 - inoculados com tumor ascítico de Ehrlich e tratados com diferentes doses de cisplatina, nos dias 2, 4, 6, 8 e 10.

Volume, número total de células tumorais e número de células Tabela 8 - tumorais por $\mathrm{mL}$ de camundongos C57BL/6 inoculados com tumor ascítico de Ehrlich e tratados com diferentes doses de cisplatina, nos dias 2, 4, 6, 8 e 10 .

Valores de hematócrito de camundongos C57BL/6 inoculados com

Tabela 9 - tumor ascítico de Ehrlich tratados com diferentes doses de cisplatina, nos dias experimentais 2, 4, 6, 8 e 10. 
Volume tumoral, número de células tumorais por $\mathrm{mL}$, número total de células tumorais e número total de células tumorais viáveis de camundongos C57BL/6 inoculados com tumor ascítico de Ehrlich e

Tabela 10 submetidos a diferentes tratamentos: $\mathrm{Co}=$ controle; $\mathrm{Cis}=$ tratado com cisplatina; CisSW = tratado com cisplatina e suainsonina; SW = tratado com suainsonina; CisRAF = tratado com cisplatina $\mathrm{e}$ fração aquosa de $I$. carnea; RAF = tratado com fração aquosa de $I$. carnea.

Número total de células viáveis, número total de células tumorais inviáveis e porcentagem de células tumorais inviáveis de Tabela 11 - camundongos C57BL/6 inoculados com tumor ascítico de Ehrlich e submetidos a diferentes tratamentos: $\mathrm{Co}=$ controle; $\mathrm{Cis}=$ tratado com cisplatina; CisSW = tratado com cisplatina e suainsonina.

Porcentagem de células tumorais nas fases sub-G1; G0/G1; S e G2/M, obtidas de camundongos C57BL/6 inoculados com tumor ascítico de Ehrlich e submetidos a diferentes tratamentos: Co =

Tabela 12 - controle; Cis = tratado com cisplatina; CisSW = tratado com cisplatina e suainsonina; $\mathrm{SW}=$ tratado com suainsonina; CisRAF = tratado com cisplatina e fração aquosa de $I$. carnea; RAF = tratado com fração aquosa de $I$. carnea.

Creatina, uréia e ALT sérica de camundongos C57BL/6 inoculados com tumor ascítico de Ehrlich e submetidos a diferentes tratamentos: branco (não inoculado); controle; $\mathrm{Cis}=$ tratado com

Tabela 13 - cisplatina; CIS-SW = tratado com cisplatina e suainsonina; SW = tratado com suainsonina; CIS-RAF = tratado com cisplatina e fração aquosa de Ipomoea carnea; RAF = tratado com fração aquosa de l. carnea.

Parâmetros hematológicos de camundongos C57BL/6 inoculados com tumor ascítico de Ehrlich e submetidos a diferentes tratamentos: branco (não inoculado); controle; $\mathrm{Cis}=$ tratado com

Tabela 14 - cisplatina; CIS-SW = tratado com cisplatina e suainsonina; SW = tratado com suainsonina; CIS-RAF = tratado com cisplatina $\mathrm{e}$ fração aquosa de Ipomoea carnea; RAF = tratado com fração aquosa de l. carnea.

Tabela 15 - Celularidade de medula óssea de camundongos de diferentes linhagens 
Volume tumoral, número de células tumorais $/ \mathrm{mL}$, número total de células tumorais e peso esplênico relativo de camundongos

Tabela 16 - C57BL/6 inoculados com tumor ascítico de Ehrlich e submetidos a diferentes tratamentos: branco (não inoculado); controle; Cis = tratado com $5 \mathrm{mg} / \mathrm{kg}$ de cisplatina; CIS-SW = tratado com cisplatina e suainsonina; $\mathrm{SW}=$ tratado com suainsonina.

Número total de células esplênicas de camundongos C57BL/6 inoculados com tumor ascítico de Ehrlich e submetidos a diferentes

Tabela 17 - tratamentos: branco (não inoculado); controle; Cis = tratado com $5 \mathrm{mg} / \mathrm{kg}$ de cisplatina; CIS-SW = tratado com cisplatina $\mathrm{e}$ suainsonina; $\mathrm{SW}=$ tratado com suainsonina.

Número total de células da medula óssea de camundongos C57BL/6 inoculados com tumor ascítico de Ehrlich e submetidos a

Tabela 18 - diferentes tratamentos: branco (não inoculado); controle; Cis = tratado com $5 \mathrm{mg} / \mathrm{kg}$ de cisplatina; CIS-SW = tratado com cisplatina e suainsonina; $\mathrm{SW}=$ tratado com suainsonina. 


\section{LISTA DE QUADROS}

Quadro 1 - grupo controle e dos grupos tratados com 0,5; 1,0 e 1,5mg/kg de cisplatina, nos dias experimentais 2, 4, 6, 8 e 10.

Descrição histopatológica de tecido renal de camundongos do

Quadro 2 - grupo controle e dos grupos tratados com 0,5; 1,0 e 1,5mg/kg de cisplatina, nos dias experimentais 2, 4, 6, 8 e 10.

Descrição histopatológica do tumor sólido de Ehrlich de Quadro 3 - camundongos do grupo controle e dos grupos tratados com 0,5; 1,0 e 1,5mg/kg de cisplatina, nos dias 2, 4, 6, 8 e 10.

Descrição histopatológica de tecido hepático de camundongos

Quadro 4 inoculados com o tumor ascítico de Ehrlich, pertencentes ao grupo controle e aos grupos tratados com 1,0; 2,0 e 3,0mg/kg de cisplatina, nos dias 2, 4, 6, 8 e 10.

Descrição histopatológica de tecido renal de camundongos

Quadro 5 inoculados com o tumor ascítico de Ehrlich, pertencentes ao grupo controle e aos grupos tratados com 1,0; 2,0 e 3,0mg/kg de cisplatina, nos dias 2, 4, 6, 8 e 10.

Descrição histopatológica de tecido hepático de camundongos

Quadro 6 C57BL/6 inoculados com o tumor ascítico de Ehrlich, pertencentes ao grupo controle e aos grupos tratados com 0,25; 0,5 e $0,75 \mathrm{mg} / \mathrm{kg}$ de cisplatina, nos dias 2, 4, 6, 8 e 10.

Descrição histopatológica de tecido renal de camundongos Quadro 7- C57BL/6 inoculados com o tumor ascítico de Ehrlich, pertencentes ao grupo controle e aos grupos tratados com 0,25; 0,5 e $0,75 \mathrm{mg} / \mathrm{kg}$ de cisplatina, nos dias 2, 4, 6, 8 e 10.

Descrição histopatológica de tecido hepático de camundongos C57BL/6 inoculados com o tumor ascítico de Ehrlich e submetidos a diferentes tratamentos: branco (não inoculado);

Quadro 8 - controle; Cis = tratado com cisplatina; CIS-SW = tratado com cisplatina e swainsonina; SW = tratado com suainsonina; CISRAF = tratado com cisplatina e fração aquosa de Ipomoea carnea; RAF = tratado com fração aquosa de l. cárnea 
Descrição histopatológica de tecido renal de camundongos C57BL/6 inoculados com o tumor ascítico de Ehrlich e submetidos a diferentes tratamentos: branco (não inoculado);

Quadro 9 - controle; Cis = tratado com cisplatina; CIS-SW = tratado com cisplatina e swainsonina; SW = tratado com suainsonina; CISRAF = tratado com cisplatina e fração aquosa de Ipomoea carnea; RAF = tratado com fração aquosa de l. cárnea

Descrição histopatológica de tecido esplênico de camundongos C57BL/6 inoculados com o tumor ascítico de Ehrlich e submetidos a diferentes tratamentos: branco (não inoculado);

Quadro 10 - controle; Cis = tratado com cisplatina; CIS-SW = tratado com cisplatina e swainsonina; SW = tratado com suainsonina; CISRAF = tratado com cisplatina e fração aquosa de Ipomoea carnea; RAF = tratado com fração aquosa de I. carnea.

Descrição histopatológica de tecido hepático de camundongos C57BL/6 inoculados com o tumor ascítico de Ehrlich e Quadro 11 - submetidos a diferentes tratamentos: branco (não inoculado); controle; Cis = tratado com cisplatina; $\mathrm{CIS}-\mathrm{SW}=$ tratado com cisplatina e swainsonina; SW = tratado com swainsonina.

Descrição histopatológica de tecido renal de camundongos C57BL/6 inoculados com o tumor ascítico de Ehrlich e

Quadro 12 - submetidos a diferentes tratamentos: branco (não inoculado); controle; Cis = tratado com cisplatina; $\mathrm{CIS}-\mathrm{SW}=$ tratado com cisplatina e swainsonina; SW = tratado com swainsonina.

Descrição histopatológica de tecido esplênico de camundongos C57BL/6 inoculados com o tumor ascítico de Ehrlich e

Quadro 13 - submetidos a diferentes tratamentos: branco (não inoculado); controle; Cis = tratado com cisplatina; CIS-SW = tratado com cisplatina e swainsonina; SW = tratado com suainsonina. 


\section{LISTA DE FIGURAS}

Avaliação do conteúdo de DNA. A - Dot plot com gate

Figura 1 - selecionando o conteúdo de DNA, B - Histograma de FL2-A mostrando as fases do ciclo celular de acordo com o conteúdo de DNA

Esquema de tratamento de camundongos C57Bl/6 inoculados com

Figura 2 - tumor sólido de Ehrlich, que receberam 0,$5 ; 1,0$ ou 1,5mg/kg de cisplatina, nos dias experimentais 4, 6, 8, 10 e 12.

Esquema de tratamento de camundongos C57Bl/6 inoculados com Figura 3 - tumor ascítico de Ehrlich, que receberam 1,0;2,0 ou 3,0mg/kg de cisplatina, nos dias experimentais 2, 4, 6, 8 e 10.

Esquema de tratamento de camundongos C57Bl/6 inoculados com

Figura 4 - tumor ascítico de Ehrlich, que receberam 0,$25 ; 0,5$ ou $0,75 \mathrm{mg} / \mathrm{kg}$ de cisplatina, nos dias experimentais 2, 4, 6, 8 e 10.

Esquema de tratamento de camundongos C57BI/6 inoculados com tumor ascítico de Ehrlich, que receberam diferentes tratamentos:

Figura 5 - Co (controle); CIS (cisplatina na dose de 0,25mg/kg); CISSW (cisplatina e suainsonina); SW (suainsonina na dose de $1 \mathrm{mg} / \mathrm{kg}$ ); CISRAF (cisplatina e RAF) e RAF (resíduo aquoso final da l.carnea).

Esquema de tratamento de camundongos C57BI/6 inoculados com tumor ascítico de Ehrlich, que receberam diferentes tratamentos:

Figura 6 BR (branco); Co (controle); CIS (cisplatina na dose de $0,25 \mathrm{mg} / \mathrm{kg}$ ); CISSW (cisplatina e suainsonina); SW (suainsonina na dose de $1 \mathrm{mg} / \mathrm{kg}$ ); CISRAF (cisplatina e RAF) e RAF (resíduo aquoso final da l.carnea).

Esquema de tratamento de camundongos C57Bl/6 inoculados com tumor ascítico de Ehrlich, que receberam diferentes tratamentos:

Figura 7 - BR (branco); Co (controle); CIS (cisplatina na dose de 0,25mg/kg); CISSW (cisplatina e suainsonina); SW (suainsonina na dose de $1 \mathrm{mg} / \mathrm{kg}$ ).

Contagem total de células da medula óssea de camundongos que receberam 0,$5 ; 1,0$ ou $1,5 \mathrm{mg} / \mathrm{kg}$ de cisplatina, nos dias

Figura 8 - experimentais 2, 4, 6, 8 e 10. São apresentadas as médias e os respectivos erros padrões ( $\mathrm{n}=5$ por grupo) (Kruskal-Wallis, $\mathrm{p}>0,05)$. 
Valores de hematócrito de camundongos tratados com 0,5; 1,0 e $1,5 \mathrm{mg} / \mathrm{kg}$ de cisplatina, nos dias experimentais 2, 4, 6, 8 e 10. São Figura 9 apresentadas as medianas, as médias (traços horizontais dentro das caixas) e os limites superiores e inferiores ( $n=5-6$ por grupo) (Kruskal-Wallis - pós teste de Dunn's * $p<0,05$, quando comparado com o grupo controle).

Peso e volume tumorais de camundongos tratados com 0,5; 1,0 e $1,5 \mathrm{mg} / \mathrm{kg}$ de cisplatina, nos dias experimentais 2, 4, 6, 8 e 10. São

Figura 10 - apresentadas as médias e os respectivos erros padrões $(n=5-9$ por grupo) (ANOVA - pós teste de Dunnett's, p>0,05, quando comparado com o grupo controle).

Fotografias de camundongo do grupo controle $(\boldsymbol{A}$ e $\boldsymbol{C})$ e do grupo Figura 11 - tratado com 1,5mg/kg de cisplatina (B e D). Em A e B nota-se a massa tumoral in situ dos animais, circulada em vermelho. Em C e D nota-se o tumor isolado destes mesmos camundongos.

Curva de sobrevida de camundongos C57BL/6 inoculados com diferentes concentrações de células tumorais de Ehrlich: $1 \times 10^{6}$

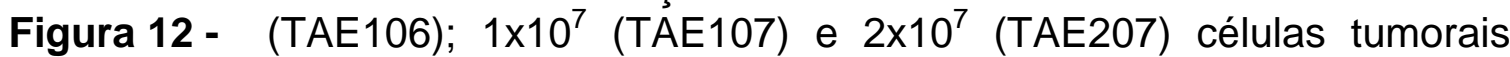
$\left(\mathrm{n}=5\right.$ por grupo). (Teste de Logrank, ${ }^{* \star *} \mathrm{P}<0,001$, quando comparado com o grupo TAE 106).

Curva de sobrevida de camundongos C57BL/6 inoculados com

Figura 13 tumor ascítico de Ehrlich,pertencentes ao grupo controle e tratados com 1,0; 2,0 e $3,0 \mathrm{mg} / \mathrm{kg}$ de cisplatina ( $\mathrm{n}=5$ por grupo). (teste de Logrank, ${ }^{*} \mathrm{p}<0,001$ quando comparado com o grupo controle).

Celularidade de medula óssea de camundongos C57BL/6 inoculados com tumor ascítico de Ehrlich e tratados com diferentes

Figura 14 doses de cisplatina, nos dias 2, 4, 6, 8 e 10. São apresentadas as médias e os respectivos erros padrões ( $n=5-8$ por grupo) (ANOVA - pós teste de Dunnett's - ${ }^{* \star} p<0,01^{\star \star *} p<0,001$, quando commparado com o grupo controle).

Número de células tumorais por $\mathrm{mL}$ de camundongos inoculados com tumor ascítico de Ehrlich e tratados com 1,0; 2,0 e 3,0mg/kg Figura 15 de cisplatina, nos dias 2, 4, 6, 8 e 10. São apresentadas as medias e os respectivos erros padrões ( $\mathrm{n}=7-9$ por grupo) (Kruskal Wallis pós teste de Dunn's * $\mathrm{p}<0,05$, quando comparado com o grupo controle). 
Volume e número total de células tumorais de camundongos inoculados com tumor ascítico de Ehrlich e tratados com 1,0; 2,0 e

Figura 16 - 3,0mg/kg de cisplatina, nos dias 2, 4, 6, 8 e 10. São apresentadas as medias e os respectivos erros padrões ( $n=7-9$ por grupo). (ANOVA - pós teste de Dunnett's ${ }^{\star \star *} p<0,001$, quando comparado com o grupo controle).

Celularidade de medula óssea de camundongos C57BL/6 inoculados com tumor ascítico de Ehrlich e tratados com diferentes

Figura 17 - doses de cisplatina, nos dias 2, 4, 6, 8 e 10. São apresentadas as medias e os respectivos erros padrões ( $n=7-9$ por grupo). (ANOVA $-p<0,05$, quando comparado com o grupo controle).

Número de células tumorais por $\mathrm{mL}$ de camundongos C57BL/6 inoculados com tumor ascítico de Ehrlich tratados com diferentes

Figura 18 - doses de cisplatina, nos dias 2, 4, 6, 8 e 10. São apresentadas as medias e os respectivos erros padrões ( $n=6-9$ por grupo). (ANOVA - $p>0,05$, quando comparado com o grupo controle).

Volume tumoral de camundongos C57BL/6 inoculados com tumor ascítico de Ehrlich tratados com diferentes doses de cisplatina, Figura 19 - nos dias 2, 4, 6, 8 e 10. São apresentadas as medias e os respectivos desvios padrões ( $n=6-9$ por grupo). (ANOVA - pós teste de Dunnett's - ${ }^{\star} \mathrm{p}<0,05 ;{ }^{* \star} \mathrm{p}<0,01$, quando comparado com o grupo controle).

Número total de células tumorais de camundongos C57BL/6 inoculados com tumor ascítico de Ehrlich tratados com diferentes

Figura 20 doses de cisplatina, nos dias 2, 4, 6, 8 e 10. São apresentadas as medias e os respectivos erros padrões ( $n=6-9$ por grupo). (ANOVA - seguida do teste de comparações múltiplas de Dunnett's ${ }^{* *} p<0,01$, quando comparado com o grupo controle).

Valores de hematócrito de camundongos C57BL/6 inoculados com tumor ascítico de Ehrlich tratados com diferentes doses de cisplatina, nos dias 2, 4, 6, 8 e 10. São apresentadas as medianas,

Figura 21 - as médias (traços horizontais dentro das caixas) e os limites superiores e inferiores ( $\mathrm{n}=5-6$ por grupo) (Kruskal-Wallis - pós teste de Dunn's - * $p<0,05$, quando comparado com o grupo controle). 
Curvas de sobrevida de camundongos C57BL/6 inoculados com tumor ascítico de Ehrlich e submetidos a diferentes tratamentos: Co = controle; Cis = tratado com cisplatina; $\mathrm{CisSW}=$ tratado com

Figura 22 - cisplatina e suainsonina; $\mathrm{SW}=$ tratado com suainsonina; CisRAF = tratado com cisplatina e fração aquosa de $I$. carnea; RAF = tratado com fração aquosa de I. carnea. (Logrank test; ${ }^{*}$ p $<0.01$, quando comparado com o grupo controle).

Curva de sobrevida de camundongos C57BL/6 inoculados com

Figura 23 - tumor ascítico de Ehrlich e submetidos a diferentes tratamentos: Co $=$ controle e RAF $=$ tratado com resíduo aquoso final da $l$. carnea. (Logrank test; $p>0,05$ )

Curva de sobrevida de camundongos C57BL/6 inoculados com

Figura 24 - tumor ascítico de Ehrlich e submetidos a diferentes tratamentos:

$\mathrm{Co}=$ controle e $\mathrm{SW}=$ tratado com suainsonina. (Logrank test; $p>0,05)$.

Curva de sobrevida de camundongos C57BL/6 inoculados com

Figura 25 - tumor ascítico de Ehrlich e submetidos a diferentes tratamentos:

$\mathrm{Co}=$ controle e Cis $=$ tratado com cisplatina na dose de $0,25 \mathrm{mg} / \mathrm{kg}$ (Logrank test; $\mathrm{p}=0,0573$ quando comparado com o grupo controle).

Curva de sobrevida de camundongos C57BL/6 inoculados com tumor ascítico de Ehrlich e submetidos a diferentes tratamentos:

Figura 26 - $\mathrm{Co}=$ controle e CisRAF = tratado com cisplatina e com RAF da $I$. carnea (Logrank test; $\mathrm{p}=0,0595$, quando comparado com o grupo controle).

Curva de sobrevida de camundongos C57BL/6 inoculados com

Figura 27 - tumor ascítico de Ehrlich e submetidos a diferentes tratamentos: Co $=$ controle e CisSW $=$ tratado com cisplatina e suainsonina (Logrank test; ${ }^{\star \star} p<0,01$, quando comparado com o grupo controle).

Curva de sobrevida de camundongos C57BL/6 inoculados com tumor ascítico de Ehrlich e submetidos a diferentes tratamentos:

Figura 28 - Cis = tratados com cisplatina e CisSW = tratado com cisplatina e suainsonina (Logrank test; ${ }^{*} \mathrm{p}<0,05$, quando comparado ao grupo Cis). 
Volume tumoral de camundongos C57BL/6 inoculados com tumor ascítico de Ehrlich e submetidos a diferentes tratamentos: Co = controle; Cis = tratado com cisplatina; CisSW = tratado com cisplatina e suainsonina; $\mathrm{SW}=$ tratado com suainsonina; CisRAF =

Figura 29 - tratado com cisplatina e fração aquosa de l. carnea; RAF = tratado com fração aquosa de $I$. carnea. São apresentadas as medias e os respectivos erros padrões ( $n=11-12$ por grupo). ANOVA - pós teste de Dunnett's - ${ }^{\star \star *} p<0,001$, quando comparado com o grupo controle.

Número de células tumorais por $\mathrm{mL}$ de amostras provenientes de camundongos C57BL/6 inoculados com tumor ascítico de Ehrlich e submetidos a diferentes tratamentos: $\mathrm{Co}=$ controle; $\mathrm{Cis}=$ tratado com cisplatina; CisSW = tratado com cisplatina e suainsonina; SW

Figura 30 - = tratado com suainsonina; CisRAF = tratado com cisplatina $\mathrm{e}$ fração aquosa de $I$. carnea; RAF = tratado com fração aquosa de $I$. carnea. São apresentadas as médias e os respectivos erros padrões ( $\mathrm{n}=11-12$ por grupo). (Kruskal-Wallis - pós teste de Dunn's - ${ }^{*} p<0,05$, quando comparado com o grupo controle).

Número total de células tumorais de camundongos C57BL/6 inoculados com tumor ascítico de Ehrlich e submetidos a diferentes tratamentos: $\mathrm{Co}=$ controle; $\mathrm{Cis}=$ tratado com cisplatina; $\mathrm{CisSW}=$ tratado com cisplatina e suainsonina; $\mathrm{SW}=$ tratado com

Figura 31 - suainsonina; CisRAF = tratado com cisplatina e fração aquosa de $I$. carnea; RAF = tratado com fração aquosa de $I$. carnea. São apresentadas as medias e os respectivos erros padrões $(n=11-12$ por grupo). (Kruskal-Wallis - pós teste de Dunn's - **p<0,01; ${ }^{\star \star \star} \mathrm{p}<0,001$, quando comparado com o grupo controle).

Número total de células tumorais viáveis provenientes de camundongos C57BL/6 inoculados com tumor ascítico de Ehrlich e submetidos a diferentes tratamentos: $\mathrm{Co}=$ controle; $\mathrm{Cis}=$ tratado com cisplatina; CisSW = tratado com cisplatina e suainsonina; SW

Figura 32 - = tratado com suainsonina; CisRAF = tratado com cisplatina e fração aquosa de $I$. carnea; RAF = tratado com fração aquosa de $I$. carnea. São apresentadas as médias e os respectivos erros padrões ( $n=11-12$ por grupo). (ANOVA - pós teste de Dunnett's ${ }^{* \star \star} p<0,001$, quando comparado com o grupo controle)

Número total de células tumorais viáveis e inviáveis de Figura 33 camundongos C57BL/6 inoculados com tumor ascítico de Ehrlich e submetidos a diferentes tratamentos: $\mathrm{Co}=$ controle; $\mathrm{Cis}=$ tratado com cisplatina; CisSW = tratado com cisplatina e suainsonina. 
Porcentagem de céluas tumorais inviáveis de camundongos C57BL/6 inoculados com tumor ascítico de Ehrlich e submetidos a diferentes tratamentos: $\mathrm{Co}=$ controle; $\mathrm{Cis}=$ tratado com cisplatina;

Figura 34 - CisSW = tratado com cisplatina e suainsonina. São apresentadas as médias e os respectivos desvios padrões ( $\mathrm{n}=11-12$ por grupo). (Kruskal-Wallis - pós teste de Dunn's - * $\mathrm{p}<0,05$, quando comparado com o grupo controle).

Histogramas de ciclos celulares (avaliados por citometria de fluxo) obtidos de células tumorais provenientes de camundongos C57BL/6 inoculados com tumor ascítico de Ehrlich e submetidos a diferentes tratamentos: Controle; $\mathrm{Cis}=$ tratado com cisplatina; CisSW = tratado com cisplatina e suainsonina; SW = tratado com

Figura 35 - suainsonina; CisRAF = tratado com cisplatina e fração aquosa de $I$. carnea; RAF = tratado com fração aquosa de I carnea. Fase subG1 ou apoptose = pico sem preenchimento; fase G0/G1 = pico de cor verde; fase $S=$ pico de cor marrom; e fase $G 2 / M=$ pico cor azul. As ilustrações mostram dados obtidos de apenas um animal do grupo em questão

Porcentagem de células tumorais, avaliadas por citometria de fluxo, nas diferentes fases do ciclo celular (<G1; G0/G1; S; G2/M), provenientes de camundongos $\mathrm{C} 57 \mathrm{BL} / 6$ inoculados com tumor ascítico de Ehrlich e submetidos a diferentes tratamentos: Co =

Figura 36 - controle; Cis = tratado com cisplatina; CisSW = tratado com cisplatina e suainsonina; $\mathrm{SW}=$ tratado com suainsonina; CisRAF = tratado com cisplatina e fração aquosa de $I$. carnea; RAF = tratado com fração aquosa de $I$. carnea. São apresentadas as médias e os respectivos erros padrões ( $n=7-11$ por grupo).

Porcentagem de células tumorais em apoptose (fase sub-G1) obtidas de camundongos C57BL/6 inoculados com tumor ascítico de Ehrlich e submetidos a diferentes tratamentos: Co = controle; Cis = tratado com cisplatina; CisSW = tratado com cisplatina $\mathrm{e}$ Figura 37 - suainsonina; SW = tratado com suainsonina; CisRAF = tratado com cisplatina e fração aquosa de I. carnea; RAF = tratado com fração 120 aquosa de I. carnea. São apresentadas as médias e os respectivos erros padrões ( $\mathrm{n}=7-11$ por grupo). (Kruskal-Wallis - pós teste de Dunn's - ${ }^{\star} \mathrm{p}<0,05$; ${ }^{* \star *} \mathrm{p}<0,001$, quando comparado com o grupo controle). 
Porcentagem de células tumorais na fase G0/G1 obtidas de camundongos C57BL/6 inoculados com tumor ascítico de Ehrlich e submetidos a diferentes tratamentos: $\mathrm{Co}=$ controle; $\mathrm{Cis}=$ tratado com cisplatina; CisSW = tratado com cisplatina e suainsonina; SW

Figura 38 - = tratado com suainsonina; CisRAF = tratado com cisplatina $\mathrm{e}$ fração aquosa de $I$. carnea; RAF = tratado com fração aquosa de $I$. carnea. São apresentadas as médias e os respectivos erros padrões ( $\mathrm{n}=7-11$ por grupo). (Kruskal-Wallis - pós teste de Dunn's ${ }^{\star} \mathrm{p}<0,05$; ${ }^{\star \star \star} \mathrm{p}<0,001$, quando comparado com o grupo controle)

Porcentagem de células tumorais na fase $S$ obtidas de camundongos C57BL/6 inoculados com tumor ascítico de Ehrlich e submetidos a diferentes tratamentos: $\mathrm{Co}=$ controle; $\mathrm{Cis}=$ tratado com cisplatina; CisSW = tratado com cisplatina e suainsonina; SW

Figura 39 - = tratado com suainsonina; CisRAF = tratado com cisplatina e fração aquosa de $I$. carnea; RAF = tratado com fração aquosa de $I$. carnea. São apresentadas as médias e os respectivos erros padrões ( $\mathrm{n}=7-11$ por grupo). Kruskal-Wallis - pós teste de Dunn's ${ }^{* \star} p<0,01 ;{ }^{* \star *} p<0,001$, quando comparado com o grupo controle).

Porcentagem de céluas na fase $\mathrm{G} 2 / \mathrm{M}$ do ciclo celular, células tumorais de camundongos C57BL/6 inoculados com tumor ascítico de Ehrlich e submetidos a diferentes tratamentos: Co = controle; Cis = tratado com cisplatina; CIS-SW = tratado com cisplatina $\mathrm{e}$

Figura 40 suainsonina; $\mathrm{SW}=$ tratado com suainsonina; CIS-AF = tratado com cisplatina e fração aquosa de Ipomoea carnea; $\mathrm{AF}=$ tratado com fração aquosa de $l$. carnea. São apresentadas as medias e os respectivos erros padrões ( $\mathrm{n}=7-11$ por grupo). (Kruskal-Wallis - pós teste de Dunn's - ${ }^{\star} p<0,05 ;{ }^{\star \star} p<0,01$, quando comparado com o grupo controle)

Uréia sérica de camundongos C57BL/6 inoculados com tumor ascítico de Ehrlich e submetidos a diferentes tratamentos: branco (não inoculado); controle; Cis = tratado com cisplatina; CIS-SW = tratado com cisplatina e swainsonina; $\mathrm{SW}=$ tratado com

Figura 41 - suainsonina; CIS-RAF = tratado com cisplatina e fração aquosa de Ipomoea carnea; RAF = tratado com fração aquosa de $I$. carnea. São apresentadas as medias e os respectivos erros padrões $(n=8-$ 11 por grupo). (ANOVA - pós teste de Dunnett's - ${ }^{*} p<0,05$, quando comparado com o grupo controle). 
ALT sérica de camundongos C57BL/6 inoculados com tumor ascítico de Ehrlich e submetidos a diferentes tratamentos: branco (não inoculado); controle; $\mathrm{Cis}=$ tratado com cisplatina; CIS-SW = tratado com cisplatina e swainsonina; $\mathrm{SW}=$ tratado com

Figura 42 - suainsonina; CIS-RAF = tratado com cisplatina e fração aquosa de Ipomoea carnea; RAF = tratado com fração aquosa de l. carnea. São apresentadas as medias e os respectivos erros padrões $(n=8-$ 11 por grupo). (ANOVA - pós teste de Dunnett's - ${ }^{\#}<<0,05$, quando comparado com o grupo branco).

Fotomicrografias dos principais achados hepáticos de camundongos C57BL/6 inoculados com o tumor ascítico de Ehrlich e submetidos a diferentes tratamentos: branco (não inoculado); controle; Cis = tratado com cisplatina; $\mathrm{CIS}-\mathrm{SW}=$ tratado com cisplatina e swainsonina; SW = tratado com suainsonina; CIS-RAF = tratado com cisplatina e fração aquosa de Ipomoea carnea; RAF

Figura 43 = tratado com fração aquosa de $I$. carnea. $1 \mathrm{~A}$ células aderidas à cápsula hepática indicadas pelas setas, grupo controle (barra 20 $\mu \mathrm{m})$. 1B hepatócitos binucleados, grupo CIS (barra 20 $\mu \mathrm{m}$ ). 1C hepatócito apresentando cario e citomegalia indicado pela seta, grupo CIS-SW (barra 20 $\mu \mathrm{m}$ ). 1D figuras de mitoses atípicas indicadas pelas setas, grupo CISRAF (barra $20 \mu \mathrm{m}$ ) 1E figuras de mitoses atípicas indicadas pelas setas, grupo CIS (barra 20 $\mu \mathrm{m}$ ). 1F figura de mitose atípica, grupo SW (barra 20 $\mu \mathrm{m})$.

Fotomicrografias dos principais achados renais de camundongos C57BL/6 inoculados com o tumor ascítico de Ehrlich e submetidos a diferentes tratamentos: branco (não inoculado); controle; Cis = tratado com cisplatina; CIS-SW = tratado com cisplatina $\mathrm{e}$ swainsonina; SW = tratado com suainsonina; CIS-RAF = tratado com cisplatina e fração aquosa de Ipomoea carnea; RAF = tratado com fração aquosa de I. carnea. 3A características histológicas

Figura 44 - normais, grupo branco (barra 20 $\mu \mathrm{m}$ ). 3B células neoplásicas aderidas à cápsula renal, grupo controle (barra 40 $\mu \mathrm{m}$ ). 3C presença de proteinúria em túbulos proximais indicada pela seta, grupo CIS-SW (barra 20 $\mu \mathrm{m}$ ). 3D presença de proteinúria em túbulos proximais indicada pela seta, grupo CIS (barra 20 $\mu \mathrm{m}$ ) 3E espessamento da cápsula de Bowman indicado pela seta, grupo CIS-SW (barra 20 $\mu \mathrm{m}$ ). 3F presença de células neoplásicas no interior de vaso renal, grupo CIS (barra $20 \mu \mathrm{m})$. 
Fotomicrografias dos principais achados esplênicos de camundongos C57BL/6 inoculados com o tumor ascítico de Ehrlich e submetidos a diferentes tratamentos: branco (não inoculado); controle; Cis = tratado com cisplatina; $\mathrm{CIS}-\mathrm{SW}=$ tratado com cisplatina e swainsonina; SW = tratado com suainsonina; CIS-RAF = tratado com cisplatina e fração aquosa de Ipomoea carnea; RAF

Figura 45 - = tratado com fração aquosa de l. carnea. 2A características histológicas normais com discreta hemossiderose, grupo branco (barra $100 \mu \mathrm{m})$. 2B megacariócitos indicados pelas setas, grupo controle (barra 20 $\mu \mathrm{m})$. 2C megacariócitos indicados pelas setas, grupo CIS (barra 20 $\mu \mathrm{m}$ ). 2D discreta hemossiderose e megacariócitos indicados pelas setas, grupo CIS (barra 20 $\mu \mathrm{m}$ ) 2E megacariócitos indicados pelas setas, grupo CIS-SW (barra 20 $\mu \mathrm{m}$ ). 2F megacariócitos indicados pelas setas, grupo SW (barra 20 $\mu \mathrm{m}$ ).

Celularidade de medula óssea de camundongos das linhagens Figura 46 - Balb-c; Swiss e C57BL/6. O traço horizontal indica a média do número de células ( $n=9-12$ por grupo). São apresentadas as medias e os respectivos erros padrões. (ANOVA, $p>0,05$ ).

Volume tumoral de camundongos C57BL/6 inoculados com tumor ascítico de Ehrlich e submetidos a diferentes tratamentos: controle; Cis = tratado com $5 \mathrm{mg} / \mathrm{kg}$ de cisplatina; CIS-SW = tratado com

Figura 47 - cisplatina e suainsonina; $S W=$ tratado com suainsonina. São apresentadas as medias e os respectivos erros padrões $(n=5-8$ por grupo). (ANOVA - pós teste de Dunnett's - ${ }^{* \star \star} p>0,05$, quando comparado com o grupo controle). 
Número de células tumorais/mL de camundongos C57BL/6 inoculados com tumor ascítico de Ehrlich e submetidos a diferentes tratamentos: controle; Cis $=$ tratado com $5 \mathrm{mg} / \mathrm{kg}$ de cisplatina; CIS-

Figura 48 - SW = tratado com cisplatina e suainsonina; $S W=$ tratado com suainsonina. São apresentadas as medias e os respectivos erros padrões ( $n=5-8$ por grupo). (ANOVA - pós teste de Dunnett's $\star \star \star x p 0,05$, quando comparado com o grupo controle).

Número de células tumorais/mL de camundongos C57BL/6 inoculados com tumor ascítico de Ehrlich e submetidos a diferentes tratamentos: controle; Cis = tratado com $5 \mathrm{mg} / \mathrm{kg}$ de cisplatina; CIS-

Figura 49 - SW = tratado com cisplatina e suainsonina; $S W=$ tratado com 141 suainsonina. São apresentadas as medias e os respectivos erros padrões ( $n=5-8$ por grupo). (ANOVA, pós teste de Dunnett's $\star \star \star p>0,05$, quando comparado com o grupo controle).

Peso esplênico relativo de camundongos C57BL/6 inoculados com tumor ascítico de Ehrlich e submetidos a diferentes tratamentos: controle; Cis = tratado com $5 \mathrm{mg} / \mathrm{kg}$ de cisplatina; CIS-SW = tratado

Figura 50 - com cisplatina e suainsonina; SW = tratado com suainsonina. São apresentadas as medias e os respectivos erros padrões $(n=5-8$ por grupo). (Kruskal-Wallis - pós teste de Dunn's - \#p>0,05, quando comparado com o grupo branco).

Número total de céluas esplênicas de camundongos C57BL/6 inoculados com tumor ascítico de Ehrlich e submetidos a diferentes tratamentos: controle; Cis = tratado com $5 \mathrm{mg} / \mathrm{kg}$ de cisplatina; CIS-

Figura 51 - SW = tratado com cisplatina e suainsonina; SW = tratado com suainsonina. São apresentadas as medias e os respectivos erros padrões ( $n=5-8$ por grupo). (ANOVA - pós teste de Dunnett's ${ }^{*} p>0,05$, quando comparado com o grupo controle).

Fotomicrografias dos principais achados de camundongos C57BL/6 inoculados com o tumor ascítico de Ehrlich e submetidos a diferentes tratamentos: branco (não inoculado); controle; Cis = tratado com cisplatina; CIS-SW = tratado com cisplatina $\mathrm{e}$ swainsonina; SW = tratado com swainsonina. 4A tecido esplênico

Figura 52 apresentando linfocitólise em centro germinativo da polpa branca, grupo CIS-SW (barra 20 $\mu \mathrm{m}$ ). 4B tecido esplênico apresentando discreta hemossiderose e megacariócitos, grupo CIS (barra 20 $\mu \mathrm{m}$ ). 4C tecido esplênico apresentando megacariócitos, grupo SW (barra 20 $\mu \mathrm{m}$ ). 4D discreto aumento da membrana basal, grupo CIS (barra $20 \mu \mathrm{m})$. 4E proteinúria em túbulos proximais, grupo CIS (barra $20 \mu \mathrm{m})$. 4F tecido hepático apresentando aumento no número de

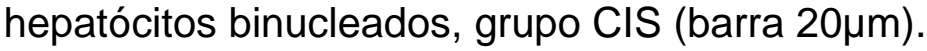




\section{SUMÁRIO}

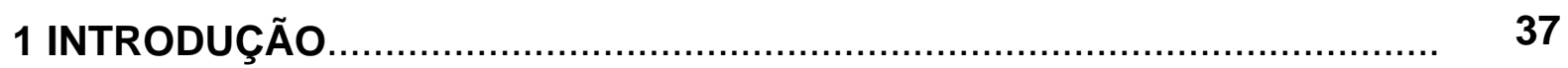

2 OBJETIVOS.

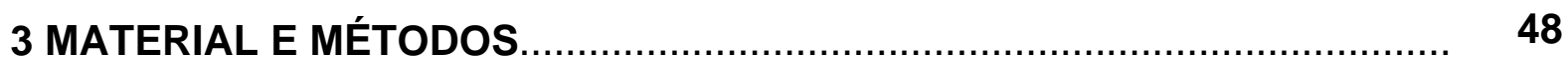

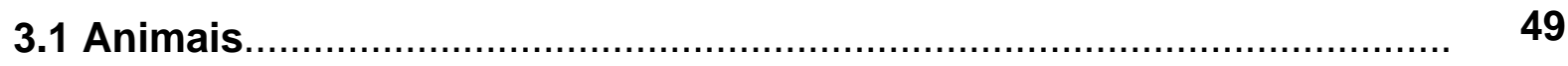

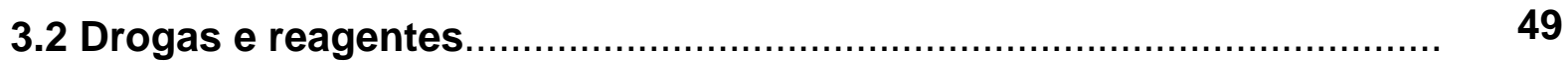

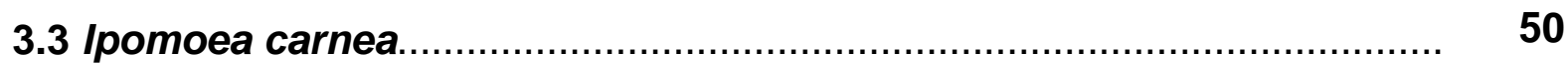

3.4 Procedimentos

3.4.1 Extração de princípios ativos da l.carnea.............................................. 50

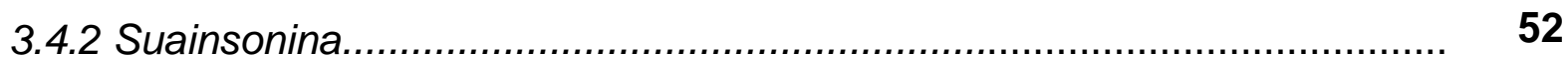

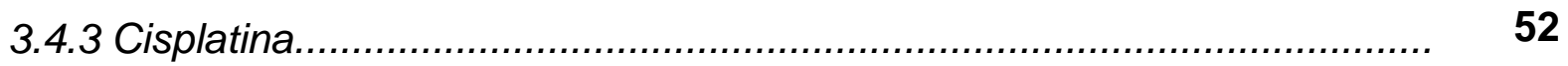

3.4.4 Resíduo Aquoso Final (RAF)...................................................... 52

3.4.5 Indução e manutenção do tumor ascítico de Ehrlich em camundongos da linhagem C57BI/6.

3.4.6 Indução do tumor sólido de Ehrlich em camundongos da linhagem C57BI/6.

3.4.7 Contagem global das células da medula óssea.................................. 54

3.4.8 Coleta de amostra sangüínea e hematócrito........................................... 55

3.4.9 Avaliação histopatológica................................................................. 55

3.4.10 Coleta do tumor sólido de Ehrlich.................................................... 56

3.4.11 Coleta do tumor ascítico de Ehrlich................................................ 56

3.4.12 Avaliação de ciclo celular por citometria de fluxo.................................. 5 
3.5 Delineamentos Experimentais

3.5.1 Experimento 1: Administração de 0,5; 1,0 e 1,5mg/kg de cisplatina em camundongos C57BL/6 inoculados com tumor sólido de Ehrlich (TSE):

60 avaliação das doses de cisplatina e do modelo experimental.

3.5.2 Experimento 2: Inoculação de $1 \times 10^{6} ; 1 \times 10^{7}$ e $2 \times 10^{7}$ células tumorais ascíticas de Ehrlich em camundongos C57BL/6: avaliação da curva de 61 sobrevida

3.5.3 Experimento 3: Administração de 1,0; 2,0 e 3,0 mg/kg de cisplatina em camundongos C57BI/6 inoculados com tumor ascítico de Ehrlich: avaliação de sobrevida, celularidade de medula óssea, volume tumoral e contagem total de células tumorais.

3.5.3.1 Avaliação de sobrevida

3.5.3.2 Celularidade de medula óssea, volume tumoral e contagem total de células tumorais.

3.5.4 Experimento 4: Administração de 0,25; 0,5 e 0,75mg/kg de cisplatina em camundongos C57BI/6 inoculados com o tumor ascítico de Ehrlich: avaliação de celularidade de medula óssea, volume tumoral e contagem total de células tumorais

3.5.5 Experimento 5: Avaliação da sobrevida de camundongos C57BI/6, inoculados com tumor ascítico de Ehrlich, tratados com suainsonina ou RAF (resíduo aquoso final) da l.carnea administrando, concomitantemente ou não, a dose de $0,25 \mathrm{mg} / \mathrm{kg}$ de cisplatina.

3.5.6 Experimento 6: Avaliação do crescimento tumoral de camundongos C57BI/6, inoculados com tumor ascítico de Ehrlich, tratados com suainsonina ou RAF (resíduo aquoso final) da l.carnea administrando, concomitantemente ou não, a dose de 0,25mg/kg de cisplatina 
3.5.7 Experimento 7: Avaliação da celularidade da medula óssea esplênica de camundongos C57BI/6 inoculados com tumor ascítico de Ehrlich tratados com suainsonina administrando, concomitantemente ou não, a dose de $5 \mathrm{mg} / \mathrm{kg}$ de cisplatina......

3.5.7.1 Teste preliminar: avaliação de celularidade da medula óssea de 71 diferentes linhagens de camundongos

3.5.7.2 Avaliação da celularidade da medula óssea e esplênica de camundongos C57BI/6 inoculados com tumor ascítico de Ehrlich tratados com suainsonina administrando, concomitantemente, ou não, a dose de $5 \mathrm{mg} / \mathrm{kg}$ de cisplatina.

3.6 Análise Estatística.

4 RESULTADOS.

4.1 Experimento 1: Administração de 0,5; 1,0 e 1,5mg/kg de cisplatina em camundongos C57BL/6 inoculados com tumor sólido de Ehrlich (TSE): avaliação das doses de cisplatina e do modelo experimental.

4.2 Experimento 2: Inoculação de $1 \times 10^{6} ; 1 \times 10^{7}$ e $2 \times 10^{7}$ células tumorais ascíticas de Ehrlich em camundongos C57BL/6: avaliação da curva de sobrevida.

4.3 Experimento 3: Administração de 1,0; 2,0 e 3,0mg/kg de cisplatina em camundongos C57BI/6 inoculados com tumor ascítico de Ehrlich: avaliação de sobrevida, celularidade de medula óssea, volume tumoral e contagem total de células tumorais.

4.3.1 Avaliação de sobrevida.

4.3.2 Celularidade de medula óssea, volume tumoral e contagem total de 87 células tumorais. 
4.4 Experimento 4: Administração de 0,25; 0,5 e 0,75mg/kg de cisplatina em camundongos C57BI/6 inoculados com o tumor ascítico de Ehrlich: avaliação de celularidade de medula óssea, volume tumoral e contagem total de células tumorais.

4.5 Experimento 5: Avaliação da sobrevida de camundongos C57BI/6, inoculados com tumor ascítico de Ehrlich, tratados com suainsonina ou RAF (resíduo aquoso final) da l. carnea administrando, concomitantemente ou não, a dose de $0,25 \mathrm{mg} / \mathrm{kg}$ de cisplatina.

4.6 Experimento 6: Avaliação do crescimento tumoral de camundongos C57BI/6, inoculados com tumor ascítico de Ehrlich, tratados com suainsonina ou RAF (resíduo aquoso final) da I. carnea administrando, concomitantemente ou não, a dose de $0,25 \mathrm{mg} / \mathrm{kg}$ de cisplatina.

4.6.1 Crescimento tumoral (volume e celularidade)

4.6.2 Citometria de fluxo

4.6.3 Análise Sanguínea.

122

4.6.4 Análise histopatológica

127

4.7 Experimento 7: Avaliação da celularidade da medula óssea esplênica de camundongos C57BI/6 inoculados com tumor ascítico de Ehrlich tratados com suainsonina administrando, concomitantemente ou não, a dose de $5 \mathrm{mg} / \mathrm{kg}$ de cisplatina.

4.7.1 Teste preliminar: avaliação de celularidade da medula óssea de diferentes linhagens de camundongos

4.7.2 Avaliação da celularidade da medula óssea e esplênica de camundongos C57Bl/6 inoculados com tumor ascítico de Ehrlich tratados com suainsonina administrando, concomitantemente, ou não, a dose de $5 \mathrm{mg} / \mathrm{kg}$ de cisplatina

4.7.2.1 Crescimento tumoral (volume e celularidade) 
4.7.2.2 Avaliação esplênica e da celularidade da medula óssea.......................

4.7.2.3 Avaliação histopatológica.............................................................. 144

5 DISCUSSÃO

6 CONCLUSÕES

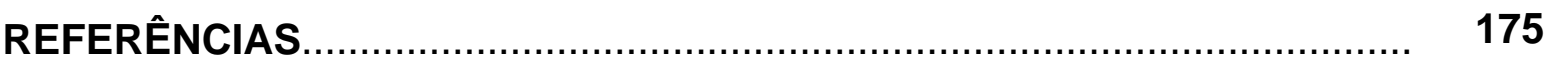


INTRODUÇÃO 


\section{INTRODUÇÃO}

O uso de plantas com fins medicinais acompanha o desenvolvimento da humanidade. De fato, o estudo de pergaminhos suméricos, com datas aproximadas a 5.000 a.C., revelou que este povo já cultivava e fazia uso do ópio, obtido da Papaver somniferum, para minorar e/ou abolir a dor (GORNIAK, 2007).

A indústria farmacêutica vem considerando o uso de plantas na medicina popular e passou a isolar diferentes princípios ativos, visando à obtenção de novos medicamentos. Pode-se citar, entre muitos exemplos, a atropina, isolada partir da Atropa belladona, e os digitálicos, isolados da Digitallis purpurae.

Uma das plantas que tem sido muito estudada em nossos laboratórios é a Ipomoea carnea (I. carnea), que pertence à família das Convolvulaceae, possuindo como características: ser uma planta arbustiva de porte ereto (medindo 1 a 3 metros de altura), caule glabro, oco e pouco ramificado; possuir seiva de aspecto leitoso; apresentar folhas lisas, alternadas, longo-pecioladas (medindo 10 e 30 centímetros de comprimento e entre 5 e 15 centímetros de largura). A sua florescência é axilar, com flores de $5-8 \mathrm{~cm}$ de comprimento e coloração variando entre o rosa e o roxo, sustentadas por longo pedúnculo. Multiplica-se por estacas e, naturalmente, por dispersão de sementes (ovóidescuneiformes, de superfície um pouco áspera e medindo entre $8 \mathrm{~mm}$ e $10 \mathrm{~mm}$ de comprimento), intensamente recobertas por pêlos ferrugíneos (HOEHNE, 1939; LORENZI, 1991). 
Além do Brasil, a I. carnea pode ser encontrada em outros países sulamericanos, como: México, Bolívia, Colômbia, Peru, Venezuela, entre outros (AUSTIN; HUAMAN, 1996). Diversos países de clima tropical possuem esta planta, principalmente países africanos como: Zimbábue, Moçambique, África do Sul e Zâmbia (GONÇALVES, 1987). Ainda, há relatos de que a I. carnea tenha sido encontrada nos Estados Unidos da América, nos estados da Flórida, Texas e Havaí, locais onde foi introduzida artificialmente e quase escapou ao controle local (AUSTIN; HUAMAN, 1996).

Esta planta propaga-se rapidamente, inclusive em condições climáticas adversas, devido à sua resistência em ambientes hostis (TIRKEY et al., 1987), e possui, desta forma, ampla distribuição nacional, recebendo diferentes nomenclaturas populares como: "algodão-bravo", no Pará; "canudo-de-lagoa", no Ceará; "algodão-do-pantanal" ou "algodão-do-brejo", no mato Grosso do Sul, entre outros nomes (TOKARNIA; DOBEREINER; PEIXOTO, 2000).

A I. carnea mantém-se verde durante todo o ano, sendo resistente a longos períodos de seca (HOEHNE, 1939). Assim, em épocas de escassez de alimento, esta planta acaba fornecendo matéria verde aos animais de produção; e, sob estas condições, bovinos, ovinos e caprinos podem intoxicar-se (TOKARNIA et al., 1960; TOKARNIA et al., 2000).

A intoxicação natural ocorre quando diferentes espécies animais ingerem a planta de forma crônica, promovendo nestes animais anorexia, perda de peso e dos índices zootécnicos. Os animais apresentam sintomatologia nervosa de origem cerebelar, com paresia de membros posteriores, tremores de cabeça, dismetria, decúbito esternal e, eventualmente, podem chegar à morte por 
inanição (HOEHNE, 1939; TOKARNIA; DOBEREINER; CANELLA, 1960; MATOS, 1983; TIRKEY; YADAVA, 1987; SRILATHA, 1997; SCHUMAHERHENRIQUE et al., 2003).

Os princípios ativos mais importantes da $I$. carnea são dois tipos distintos de alcalóides: o alcalóide indolizidínico suainsonina, e os alcalóides nortropânicos calisteginas B1, B2 e C1.

O mecanismo de ação da suainsonina é conhecido há muito tempo, pois este alcalóide não é exclusivo da I. carnea, sendo encontrado em outras plantas distribuídas pelo mundo, como na planta australiana da família das Leguminoseae Swainsona canescens (DORLING; HUXTABLE; VOGUEL, 1978); em algumas espécies estados-unidenses conhecidas como locoweed do gênero Astragalus e Oxytropis (VAN KAMPEN; JAMES, 1970); além de outras espécies de Ipomoea, como a I. muelleri, comuns no oeste australiano (GARDINER; ROYCE; OLDROY, 1965). A suainsonina pode ser produzida como metabólito secundário por alguns fungos, como aqueles do gênero Metarhizium spp. (TULLOCH, 1976) e Rhizoctonia spp. (SCHNEIDER et al., 1983).

A suainsonina inibe duas enzimas intracelulares: a $\alpha$-manosidase e a $\alpha$ manosidase II do Complexo de Golgi. A enzima a-manosidase (que também pode ser chamada de a-manosidase ácida ou a-manosidase lisossômica) é encontrada confinada no interior de lisossomos e é responsável pelo catabolismo dos N-glicanos. Quando ocorre sua inibição, estes oligossacarídeos (principalmente os ricos em resíduos $\alpha$-manosil e $\beta$ - $N$-acetilglicosamina) não são metabolizados e, consequentemente, acumulam-se no interior desta organela, 
levando a um processo de degeneração vacuolar lisossomal que pode levar à perda de sua função e, finalmente, causar a morte celular (TULSIANI, 1988).

Os sintomas nos animais intoxicados naturalmente com a suainsonina (através da ingestão de plantas que possuem este princípio ativo), geralmente, se apresentam após o contato crônico com a mesma, sendo as principais manifestações de caráter neurológico. Análises histopatológicas do sistema nervoso central de tais animais, principalmente caprinos, revelaram a presença de degeneração vacuolar de neurônios, sendo os neurônios cerebelares os mais acometidos (DE BALOGH et al., 1999; SCHUMAHER-HENRIQUE et al., 2003).

A a-manosidase II do Complexo de Golgi está envolvida no processo de glicolisação das glicoproteínas, cabendo a esta manosidase remover ou alterar os padrões de resíduos de manose em glicoproteínas ( $N$-glicanos) recém sintetizados no retículo endoplasmático rugoso. Assim, sua inibição promove alterações importantes nestas macromoléculas, resultando na formação de glicoproteínas defeituosas (MOREMEN; ROBBINS, 1991) ou levando a um acúmulo de cadeias pesadas de glicoproteínas na membrana celular (ELBEIN et al., 1989).

É valido ressaltar que muitas macromoléculas de grande importância biológica são glicoproteínas, tais como: hormônios, moléculas de adesão, receptores de membrana, imunoglobulinas, citocinas, entre outras (STEGELMEIER et al., 1998a). As fibronectinas, por exemplo, são importantes glicoproteínas, de alto peso molecular, que participam dos processos de migração e adesão celular (YAMADA, 2000; PANKOV, YAMADA, 2002). 
Estudos mostram a atuação das fibronectinas e das integrinas em processos neoplásicos como: manutenção da integridade da massa tumoral e estimulação da proliferação celular, adesão e migração tumoral. Tais interações, que ocorrem entre as fibronectinas e integrinas, podem ser vistas como um importante ponto na progressão tumoral (HOCKING et al., 1998).

Considerando que a suainsonina pode causar alterações em glicoproteínas de membrana e, conseqüentemente, a participação destas em processos neoplásicos, alguns estudos foram feitos para se avaliar a capacidade desta substância alterar características das células tumorais. Foi observado que a suainsonina inibe o crescimento (em até 50\%) de melanoma humano implantado em camundongos nude (animais deficientes em linfócitos T), exercendo, assim, um efeito antineoplásico (DENNIS et al., 1990). Além disso, Humphries et al. (1986a, 1986b) observaram que células de melanoma murino (B16-F10) tratadas com a suainsonina apresentavam menor atividade metastática.

Tumores transplantáveis são modelos experimentais úteis para a compreensão dos mecanismos envolvidos na proliferação de células tumorais e em processos neoplásicos. O tumor transplantável de Ehrlich é amplamente estudado e empregado em diferentes modelos experimentais que avaliam o desenvolvimento tumoral e as características inerentes da atividade neoplásica. Este tumor é originário de um carcinoma mamário de camundongos fêmeas e foi primeiramente descrito por Ehrlich em 1906. Pode se desenvolver de duas maneiras, dependendo do local onde é implantado: na forma ascítica, quando a inoculação é feita na cavidade peritoneal, e na forma sólida, quando inoculado no 
interstício da musculatura esquelética (EHRLICH, 1906; GUERRA, 1983). Este modelo tem sido empregado no estudo da ação de componentes químicos, físicos e biológicos sobre o crescimento, patogênese, imunologia, citogenética e terapêutica de células tumorais (SEGURA et al., 2000; MADY, 2002; PALERMONETO et al., 2003; SILVA, 2003). A vantagem da utilização de modelos tumorais transplantáveis, em comparação aos demais modelos experimentais, recai sobre o conhecimento prévio da quantidade e das características iniciais das células tumorais a serem inoculadas e sobre o desenvolvimento rápido da neoplasia, que diminui a duração experimental (STEWART et al., 1959).

Achados de literatura mostram que a suainsonina, quando administrada a camundongos, promove aumento na atividade proliferativa de células da medula óssea (OLDEN et al., 1991; OREDIPE et al., 2003a, 2003b), mesmo durante o uso de quimioterápicos citotóxicos (OREDIPE et al., 1991). Estes dados sugerem que este alcalóide poderia ser útil como protetor da medula óssea se usado juntamente com radioterapia ou quimioterapia.

Um medicamento usado na quimioterapia de alguns tipos de câncer é a cisplatina, composto inorgânico que possui platina em sua molécula, que se intercala no interior e entre as fitas do DNA, interagindo principalmente com o nitrogênio sete da guanina e da adenosina, formando ligações que, em última análise, impedem as funções de transcrição e replicação, inativando o DNA da célula. Após a aplicação intravenosa, a cisplatina rapidamente se distribui para fígado, rins e intestinos, e sua excreção é diretamente dependente da função renal; apenas uma pequena porcentagem dos metabólitos é eliminada pela bile (SRIGANTH, PREMALATHA, 1999; LUCAS, DAGLI, 2007). 
A maior limitação do uso da cisplatina é a sua ação tóxica em tecidos normais, possuindo efeitos adversos em rins, trato gastrintestinal, nervos periféricos e na medula óssea (VON HOFF et al., 1979; HARRAP et al., 1980; ROSE et al., 1982). A mielossupressão torna-se particularmente severa em tratamentos com doses mais elevadas de cisplatina, fato que limitou seu uso terapêutico nas últimas décadas (OZOLS et al., 1984; GANDARA et al., 1986; GRINGERI et al., 1988; OGILVIE, 1998; GENTILE et al., 2001; McKNIGHT, 2003).

Considerando os dados aqui expostos, o presente estudo teve como objetivo avaliar os possíveis efeitos antineoplásicos e mieloprotetores da $I$. carnea e de seu princípio ativo, a suainsonina, em camundongos inoculados com Tumor Ascítico de Ehrlich. A cisplatina foi usada como droga de controle positivo (por ser sabidamente um efetivo antineoplásico) e como princípio mieloagressor (OZOLS et al., 1984; GANDARA et al., 1986; GRINGERI et al., 1988). Optou-se pelo uso do resíduo aquoso final (RAF) neste projeto pelo fato desta preparação (na qual a suainsonina foi identificada e quantificada) ter sido empregada em vários outros estudos realizados em nossos laboratórios (SCHWARZ et al, 2003, 2004; HUEZA et al, 2003a, 2003b, 2005; LATORRE et al, 2007). 
OBJETIVOS 


\section{OBJETIVOS}

\subsection{Objetivo geral}

Avaliar os possíveis efeitos antineoplásicos e mieloprotetores da l. carnea e de seu princípio ativo, a suainsonina, em camundongos inoculados com o tumor de Ehrlich.

\subsection{Objetivos específicos}

Definir a dose de cisplatina a ser empregada em camundongos inoculados com o tumor sólido e ascítico de Ehrlich;

$>$ Estabelecer as condições da inoculação do tumor ascítico de Ehrlich em camundongos C57BL/6;

Avaliar os efeitos da suainsonina ou do RAF da l. carnea administrados isoladamente ou em associação com a cisplatina na sobrevida de camundongos inoculados com tumor ascítico de Ehrlich;

Verificar os efeitos da suainsonina ou do RAF da I. carnea administrados isoladamente ou em associação com a cisplatina no crescimento tumoral de camundongos inoculados com o tumor ascítico de Ehrlich; 
Avaliar os efeitos da suainsonina administrada isoladamente ou em associação com a cisplatina na celularidade da medula óssea e esplênica de camundongos inoculados com o tumor ascítico de Ehrlich. 


\section{MATERIAIS \& MÉTODOS}




\section{MATERIAIS E MÉTODOS}

\subsection{Animais}

Foram utilizados camundongos machos da linhagem C57BI/6, com aproximadamente 60 dias de vida, todos provenientes do biotério do Departamento de Patologia da Faculdade de Medicina Veterinária e Zootecnia da Universidade de São Paulo (FMVZ/USP). Os animais foram alojados em caixas de plástico fosco de cor branca, medindo $19,5 \times 29,5 \times 13,0 \mathrm{~cm}$, fechadas com tampas de tela metálica. As caixas foram mantidas em salas com temperatura e umidade controladas $\left(21-24^{\circ} \mathrm{C}\right.$ e $65-70 \%$, respectivamente). O presente projeto foi aprovado pelo comitê de Bioética da Faculdade de Medicina Veterinária e Zootecnia - USP (protocolo número 1161).

\subsection{Drogas e reagentes}

Os principais reagentes e drogas utilizadas durante esse trabalho foram: ácido acético (Synth), azul de Trypan (Gibco), cloreto de sódio (Nuclear), cisplatina (Platistine®-Pfizer), clorofórmio (Nuclear), EDTA 1mM (Sigma), meio RPMI (Gibco), metanol (Synth), penicilina e estreptomicina (Gibco), solução de 
formalina a 4\%, soluções de PBS e PBS glicosado (Sigma), solução de $\mathrm{NaCl}$ a $0,9 \%$, tripsina (Life Technologies), soro bovino fetal (Gibco), suainsonina (gentilmente cedida pelo Dr. Dale Gardner do Poisonous Plant Research Laboratory - United States Department of Agricultural (USDA) - EUA), xilazina (Anasedan®-Vetbrands) e cetamina. (Dopalen®-Vetbrands).

\subsection{Ipomoea carnea}

As folhas frescas da I.carnea foram colhidas, entre os meses de julho e agosto de 2007, na plantação existente no Centro de Pesquisas em Toxicologia Veterinária (CEPTOX), pertencente ao Departamento de Patologia da FMVZ/USP, situado no Campus de Pirassununga-SP.

\subsection{Procedimentos}

\subsubsection{Extração de princípios ativos da l.carnea}

As folhas frescas de l.carnea foram trituradas em um liquidificador e maceradas a frio com álcool etílico $95 \%$ durante três dias. O extrato etanólico obtido foi filtrado e o resíduo vegetal voltou para um recipiente de vidro para uma nova extração com álcool etílico $95 \%$; este processo foi repetido por quatro 
vezes, sempre utilizando o mesmo resíduo vegetal obtidos das folhas maceradas.

Os extratos foram reunidos e concentrados através de um rota-evaporador sob pressão reduzida à $50^{\circ} \mathrm{C}$ para eliminar o solvente (álcool etílico $95 \%$ ), sendo em seguida dissolvidos em água destilada e filtrados em papel de filtro pregueado para separar a porção insolúvel da porção solúvel.

A porção solúvel foi fracionada por partição com solvente imiscível, butanol saturado com água, até a porção butanólica ficar com coloração clara. A solução aquosa final deste fracionamento foi concentrada totalmente para obtenção do resíduo aquoso final (RAF), sendo este administrado aos animais.

A quantificação dos princípios ativos contidos no RAF da l.carnea foi feita pelo Prof. Dr. Dale R. Gardner do Poisonous Plant Research Laboratory, USDA Agricultural Research Service (Logan, Utah, EUA). Foi empregada cromatografia líquida de alta eficiência (HPLC) acoplada a espectrômetro de massas (MS), sendo constatada a presença de $0,14 \%$ de suainsonina, $0,07 \%$ de calistegina $B 2$, 0,03 de calistegina B1 e 0,03\% de calistegina C1.

A partir dos valores percentuais encontrados, e levando-se em consideração que as folhas da l.cárnea possuem $75 \%$ de umidade, encontrou-se, como mostra a tabela 1, a real concentração, em miligramas da fração aquosa por quilo de peso corpóreo do animal, dos alcalóides suainsonina e calisteginas $\mathrm{B} 1, \mathrm{~B} 2$ e C1, na dose de 3,0g de folha seca/ $\mathrm{kg} / \mathrm{dia}$. 
Tabela 1: Proporção (em $\mathrm{mg} / \mathrm{kg} / \mathrm{dia}$ ) dos princípios ativos encontrados na dose de $3 \mathrm{~g}$ de folha seca $/ \mathrm{kg}$ do resíduo aquoso final da Ipomoea cárnea administrado aos camundongos

\begin{tabular}{cc}
\hline Princípios ativos & $\mathbf{m g} / \mathbf{k g} / \mathbf{d i a *}$ \\
Calistegina B1 & 0,84 \\
Calistegina B2 & 0,24 \\
Calistegina C1 & 0,63 \\
\end{tabular}

*Estes valores foram calculados a partir da matéria seca proveniente das folhas frescas da planta.

\subsubsection{Suainsonina}

A suainsonina foi diluída em água destilada estéril e administrada por via intraperitoneal, na dose de $1 \mathrm{mg} / \mathrm{kg}$ de peso vivo (OREDIPE et al., 2003).

\subsubsection{Cisplatina}

A cisplatina foi diluída em água estéril, a fim de permitir a administração de diferentes doses deste fármaco. Os animais foram tratados por via intraperitoneal.

\subsubsection{Resíduo Aquoso Final (RAF)}

A administração do RAF da l.carnea foi realizada por via oral (gavage), na dose de $3 \mathrm{~g}$ de folhas secas de l.carnea por quilo de peso vivo; tal dose equivale 
aproximadamente à concentração de $0,84 \mathrm{mg} / \mathrm{dia}$ de suainsonina existente no RAF, administrado por via oral (HUEZA et al., 2003; LATORRE et al., 2007).

3.4.5 Indução e manutenção do tumor ascítico de Ehrlich em camundongos da linhagem C57BI/6

Em nossos laboratórios, as células ascíticas do tumor de Ehrlich são mantidas in vivo em camundongos da linhagem Balb-c. Para o emprego destas células em outras linhagens de camundongos (por exemplo, C57bl/6, Swiss e outras), é necessário que estas células tumorais adquiram características pertinentes a nova linhagem animal. Assim, foi estabelecido em nosso laboratório que o tumor deve ser transplantado no peritônio da linhagem experimental desejada, por pelo menos 12 vezes. Este protocolo foi seguido, e o tumor ascítico de Ehrlich foi perpetuado em camundongos da linhagem C57BI/6, obtendo assim células tumorais adaptadas à linhagem estudada neste trabalho.

Para tal, após submeter o camundongo portador da ascite tumoral à eutanásia, as células tumorais foram coletadas da cavidade peritoneal com uma seringa $(5 \mathrm{~mL})$ e uma agulha $(0,55 \times 20 \mathrm{~mm})$, acondicionadas em tubo falcon $(50 \mathrm{~mL})$ e mantidas a uma temperatura de $4^{\circ} \mathrm{C}$. Após a hemólise de eritrócitos, (que podem estar presentes no líquido tumoral), as células de Ehrlich foram mantidas em PBS e contadas em uma câmara de Newbauer, aceitando-se no mínimo 95\% de viabilidade (observada pela coloração com azul de Trypan). Para a linhagem C57BI/6, estipulou-se a concentração a ser inoculada de $2 \times 10^{7}$ células tumorais/animal em $200 \mu$ l. 
3.4.6 Indução do tumor sólido de Ehrlich em camundongos da linhagem C57BI/6

As células tumorais ascíticas perpetuadas em camundongos C57BI/6 foram ajustadas para a concentração de $1 \times 10^{6}$ cél/animal em $100 \mu$ l e foram administradas, por via intramuscular, na região inguinal esquerda dos camundongos (GHOSH, MAITY; 2006).

\subsubsection{Contagem global das células da medula óssea}

As células da medula óssea foram obtidas da cavidade femoral de cada animal, após a lavagem da mesma com $5,0 \mathrm{~mL}$ de solução resfriada de RPMI (ajustada no $\mathrm{pH}$ de 7,4 ). As células foram acondicionadas em tubos falcon de $15 \mathrm{~mL}$ e dispersas com auxílio de pipeta tipo Pasteur até se obter uma suspensão celular homogênea. Posteriormente, $10 \mu \mathrm{l}$ desta amostra foram colhidos e diluídos na razão de 1:100 em Azul de Trypan (diluído 6x em PBS). A viabilidade e contagem global das células nucleadas foram realizadas em câmara de Newbauer; as células foram contadas nos quatro quadrantes externos da câmara, em aumento de dez vezes. 


\subsubsection{Coleta de amostra sangüínea e hematócrito}

Os animais foram anestesiados com xilazina e cetamina, por via intraperitoneal ou intramuscular; as cavidades abdominais e torácicas foram abertas e amostras de sangue foram coletadas com anticoagulante (EDTA 10\%) por punção cardíaca. O hemograma foi realizado logo após a coleta do sangue com anticoagulante em contador automático de células (Vet ABC Animal Blood Counter - Horiba ABX Diagnostics). Os seguintes parâmentros foram obtidos automaticamente: número de glóbulos brancos (leucócitos); número de glóbulos vermelhos (hemácias); número de plaquetas, quantidade de hemoglobina; hematócrito; volume corpuscular médio (VCM); hemoglobina corpuscular média (HCM) e concentração de hemoglobina corpuscular média ( $\mathrm{CHCM})$.

O sangue coletado sem anticoagulante foi mantido em temperatura ambiente até a formação de coágulo (aproximadamente 45 minutos) e então centrifugado (Centrífuga Sanyo-Harrier 18/80, 4000rpm, por 10 minutos). Em seguida, o soro obtido foi armazenado a $-80^{\circ} \mathrm{C}$ até o momento da análise por meio do autoanalizador CELM SBA-200® utilizando kits comerciais CELM®. Foram determinados os níveis séricos de creatina, uréia, alanina aminotransferase (ALT) e aspatato aminotransferase (AST).

\subsubsection{Avaliação histopatológica}

Após o período experimental, os animais foram submetidos à eutanásia (através de aprofundamento de anestesia com xilazina e cetamina), para 
avaliação macroscópica de possíveis lesões e para coleta dos seguintes órgãos: fígado, baço e rins. Estes tecidos foram fixados em formol (10\%) e emblocados em parafina e, posteriormente, as lâminas foram coradas pela técnica de hematoxilina e eosina $(\mathrm{HE})$.

Estas lâminas histopatológicas foram observadas em microscópio de luz, acoplado com a máquina fotográfica Nikon DXM 1200c; para análise das imagens foi usado o programa IMAGEN PRO PLUS.

\subsubsection{Coleta do tumor sólido de Ehrlich}

Os animais foram anestesiados com xilazina e cetamina, por via intraperitoneal. A porção interna dos membros posteriores esquerdos foi borrifada com etanol $(70 \%)$ e o tecido epidérmico foi rebatido para expor a região onde ocorreu o crescimento da massa tumoral (item 3.4.6). A massa tumoral foi isolada com assistência de bisturi e pinça, posteriormente foi pesada (em balança analítica) e medida com um paquímetro digital.

\subsubsection{Coleta do tumor ascítico de Ehrlich}

Os animais foram anestesiados com xilazina e cetamina, por via intramuscular, e a epiderme da região abdominal foi rebatida, para expor assim o peritônio destes animais. Com auxílio de agulha $(0,55 \times 20 \mathrm{~mm})$ e seringa $(3 \mathrm{~mL}) \circ$ líquido tumoral foi colhido da cavidade abdominal. A seguir, essa amostra foi 
acondicionada em tubos falcons de $50 \mathrm{~mL}$, para análises posteriores, tais como: mensuração do volume tumoral; celularidade tumoral total; celularidade por $\mathrm{mL}$; leitura das células tumorais em citômetro de fluxo; bem como a avaliação da população de células viáveis e inviáveis, por meio da contagem de células em câmara de Neubauer coradas, ou não, com Azul de Trypan (as células inviáveis se coram em azul). Estes procedimentos estão de acordo com os propostos por Dagli, 1989.

\subsubsection{Avaliação de ciclo celular por citometria de fluxo}

Os procedimentos seguiram a metodologia proposta por Spector et al. (1998) com algumas alterações. Após a coleta do líquido ascítico tumoral, as células foram contadas e ajustadas para $1 \times 10^{6}$ células em $1 \mathrm{~mL}$ de etanol $70 \%$ a $4^{\circ} \mathrm{C}$ para fixação, sendo mantidas a $-20^{\circ} \mathrm{C}$ até 0 momento da análise por

citometria de fluxo. As amostras foram centrifugadas a $1800 \mathrm{rpm}$ durante 10 minutos, o sobrenadante foi desprezado e estas foram "lavadas" três vezes em $1 \mathrm{~mL}$ de PBS, ressuspendidas em $200 \mu \mathrm{L}$ de solução de iodeto de propídeo $(20 \mathrm{~mL}$ de PBS, $20 \mu \mathrm{L}$ de triton $100[0,1 \% \mathrm{v} / \mathrm{v}], 200 \mu \mathrm{L}$ de RNase $A[20 \mathrm{mg} / \mathrm{mL}]$ e $80 \mu \mathrm{L}$ de iodeto de propídeo $[5 \mathrm{mg} / \mathrm{mL}])$. As células foram incubadas nesta solução por 15 minutos, ao abrigo da luz, a $37^{\circ} \mathrm{C}$ e, em seguida procedeu-se a leitura em citômetro de fluxo.

Foi utilizado um citômetro de fluxo (Becton Dickison Immunocytometry System, San Jose, CA, USA) conectado a um computador (Machintosh Apple, 
CA, USA), sendo os eventos adquiridos por meio de um programa denominado Cell Quest Pro® (Becton Dickison Immunocytometry System, San Jose, CA, USA).

Foram adquiridos 10.000 eventos por amostra a uma velocidade máxima de 200 eventos por segundo no filtro FL2-A (585nm). Para análise do conteúdo de DNA fez-se a eliminação dos eventos duplicados (doublets) por meio de gate no gráfico de FL2-AxFL2-W e, em seguida, a análise em histograma de FL-2a, conforme ilustrado na figura 1 . Todos os dados foram analisados através do programa FlowJo 7.2.2® (Tree Star Inc, Ashland, USA), e os resultados expressos em procentagem para cada fase do ciclo celular (DNA CELL CYCLE ANALYSIS).
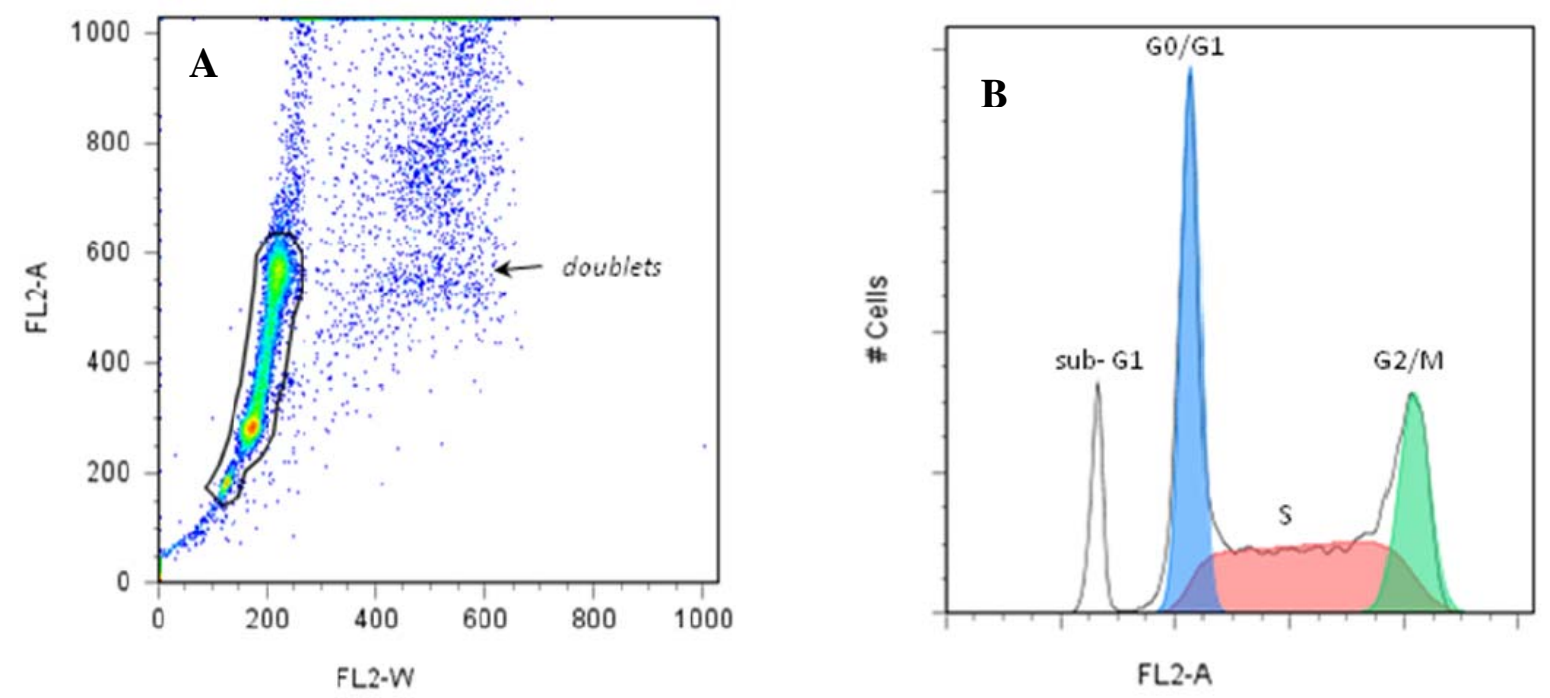

Figura 1: Avaliação do conteúdo de DNA. A - Dot plot com gate selecionando o conteúdo de DNA, B - Histograma de FL2-A mostrando as fases do ciclo celular de acordo com o conteúdo de DNA 
Por meio do citômetro de fluxo pode-se detectar a incorporação de iodeto de propídeo ao DNA e dessa maneira, determinar a fase do ciclo mitótico ou divisão celular, no qual uma célula "mãe" gera duas células "filhas" idênticas a partir da duplicação e posterior divisão de seu material genético. Este processo é cíclico e composto de cinco fases distintas: G0, G1 (gap-1), S (síntese), G2 (gap2) e M (mitose) - MALUMBRES; BARBACID, 2001. Durante a fase G0 as células se encontram em equilíbrio, mantendo seu metabolismo normal. Na fase G1 as células respondem a estímulos proliferativos que dão início ao processo de divisão celular; é uma fase de crescimento citoplasmático. Na fase $S$ ocorre a duplicação do material genético. Durante a fase G2 há a conferência do material genético e uma nova fase de crescimento citoplasmático. Na fase $\mathrm{M}$ ocorre a divisão de todos os componentes celulares e a formação de duas células "filhas" idênticas.

Quando ocorrem danos ao material genético, mecanismos de checkpoints da proliferação celular são ativados e levam à parada do ciclo celular. A impossibilidade de reparo deste material genético pode levar a célula a diferentes processos de morte celular, sendo o mais comum o processo apoptótico. Este processo é caracterizado pelo encolhimento celular, bem como pela condensação da cromatina nuclear. Nos estágios mais adiantados, o núcleo celular se condesa e se rompe (esse fenômeno é chamado de cariorrexia) e, posteriormente, ocorre à formação de corpúsculos apoptóticos repletos de organelas e fragmentos de material genético (SARASTE; PULKKI, 2000). Desse modo, a análise do ciclo celular por incorporação de iodeto de propídeo ao DNA permite verificar os efeitos de um determinado tratamento no crescimetno 
tumoral, pois é possível identificar "paradas" no ciclo celular, que é observada como um acúmulo de células em uma das fases do ciclo e, além disso, também é possível identificar a apoptose celular, que se caracteriza pelo surgimento de um pico sub-G1.

\subsection{Delineamentos Experimentais}

3.5.1 Experimento 1: Administração de 0,5; 1,0 e 1,5mg/kg de cisplatina em camundongos C57BL/6 inoculados com tumor sólido de Ehrlich (TSE): avaliação das doses de cisplatina e do modelo experimental

Trinta e três camundongos da linhagem C57BI/6 receberam, por via intramuscular, na região inguinal do membro esquerdo, $1 \times 10^{6}$ células tumorais para indução do tumor sólido de Ehrlich, conforme descrito no item 3.4.6. O dia da inoculação foi considerado o dia 0 (zero) experimental. A seguir, os animais foram distribuídos em quatro grupos, um controle e três experimentais $(n=8-9)$. Os animais dos grupos experimentais receberam, por via intraperitoneal, as seguintes doses de cisplatina: 0,$5 ; 1,0$ ou $1,5 \mathrm{mg} / \mathrm{kg}$ (item 3.4.3) em dias alternados, ou seja, durante os dias experimentais $04,06,08 ; 10$ e 12 . Os camundongos do grupo controle receberam, pela mesma via e nos mesmos dias, $10 \mathrm{ml} / \mathrm{kg}$ de água destilada.

No 14。 dia experimental todos os camundongos foram submetidos à eutanásia. Foi avaliada a celularidade da medula óssea (3.4.7), e o hematócrito 
dos animais (3.4.8). O peso e o volume tumoral foram mensurados (item 3.4.10), também foi realizado o estudo histopatológico deste tecido (item 3.4.9). A figura 2 representa o esquema de tratamento deste experimento.

\begin{tabular}{|c|c|c|c|c|c|c|c|c|}
\hline Animais & Dia 0 & Grupos & $\begin{array}{c}\text { Dia } \\
04 \\
\end{array}$ & $\begin{array}{l}\text { Dia } \\
06\end{array}$ & $\begin{array}{l}\text { Dia } \\
08 \\
\end{array}$ & $\begin{array}{l}\text { Dia } \\
10 \\
\end{array}$ & $\begin{array}{l}\text { Dia } \\
12 \\
\end{array}$ & $\begin{array}{l}\text { Dia } \\
14 \\
\end{array}$ \\
\hline & \multirow{4}{*}{ 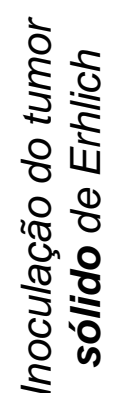 } & Controle & & & & & & tro \\
\hline & & CIS 0,5mg/kg & $\not \subset$ & $\not$ & $\not$ & $\not$ & $\not \subset$ & $\not x$ \\
\hline & & CIS 1,0mg/kg & $\not$ & $\not$ & $\not$ & $\phi$ & $\not \varnothing$ & $\not 2$ \\
\hline & & CIS 1,5mg/kg & $\not \varnothing$ & $\not$ & $\phi$ & $\not \subset$ & $\phi$ & $\not R$ \\
\hline
\end{tabular}

Figura 2: Esquema de tratamento de camundongos C57BI/6 inoculados com tumor sólido de Ehrlich, que receberam 0,$5 ; 1,0$ ou 1,5mg/kg de cisplatina, nos dias experimentais $4,6,8,10$ e 12. Os locais marcados com " $\phi$ " representam os dias em que os animais receberam os diferentes tratamentos de cisplatina. Os símbolos " $\mathrm{\alpha}$ " representam a eutanásia dos animais

3.5.2 Experimento 2: Inoculação de $1 \times 10^{6} ; 1 \times 10^{7}$ e $2 \times 10^{7}$ células tumorais ascíticas de Ehrlich em camundongos C57BL/6: avaliação da curva de sobrevida

Foram empregados 15 camundongos da linhagem C57BI/6, que foram divididos em três grupos $(n=5)$, denominados TAE106; TAE107 e TAE207 de acordo com o número de células tumorais inoculadas, ou seja, os grupos receberam as seguintes concentrações de células tumorais: $1 \times 10^{6} ; 1 \times 10^{7}$ e $2 \times 10^{7}$

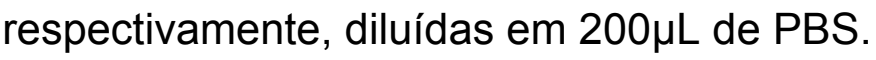

As células foram inoculadas por via intraperitoneal (item 3.4.5). O dia da inoculação tumoral foi considerado o dia 0 (zero) do período experimental. Os 
camundongos foram acompanhados diariamente para avaliação da evolução da ascite tumoral e das eventuais mortes, sendo estas contabilizadas para a análise estatística da curva de sobrevida dos animais.

3.5.3 Experimento 3: Administração de 1,0; 2,0 e 3,0mg/kg de cisplatina em camundongos C57BI/6 inoculados com tumor ascítico de Ehrlich: avaliação de sobrevida, celularidade de medula óssea, volume tumoral e contagem total de células tumorais

\subsubsection{Avaliação de sobrevida}

Vinte camundongos $\mathrm{C} 57 \mathrm{BI} / 6$ receberam por via intraperitoneal $2 \times 10^{7}$ células tumorais de Ehrlich, conforme descrito no item 3.4.5. O dia da inoculação tumoral foi considerado como o dia 0 (zero) experimental. Os animais foram distribuídos em quatro grupos, um controle e três experimentais $(n=5)$. Os camundongos do grupo experimental receberam por via intraperitoneal doses de 1,$0 ; 2,0$ e $3,0 \mathrm{mg} / \mathrm{kg}$ de cisplatina (item 3.4.3) em dias alternados, ou seja, durante os dias experimentais $02 ; 04,06,08$ e 10 . Os animais do grupo controle receberam, nestes mesmos dias, $10 \mathrm{~mL} / \mathrm{kg}$ de água destilada, pela mesma via de administração.

Após o término do tratamento os animais foram acompanhados diariamente para avaliação da evolução da ascite e das eventuais mortes, sendo 
estas contabilizadas para a análise estatística da curva de sobrevida dos camundongos.

3.5.3.2 Celularidade de medula óssea, volume tumoral e contagem total de células tumorais

Trinta e dois camundongos $\mathrm{C} 57 \mathrm{BI} / 6$ receberam por via intraperitoneal $2 \times 10^{7}$ células tumorais de Ehrlich, conforme descrito no item 3.4.5. O dia da inoculação tumoral foi considerado como o dia 0 (zero) do período experimental. Os animais foram distribuídos em quatro grupos, um controle e três experimentais $(n=7-9)$. Os animais dos grupos experimentais receberam cisplatina, por via intraperitoneal, nas doses de 1,0;2,0 e 3,0mg/kg (item 3.4.3) em dias alternados, ou seja, durante os dias experimentais 02; 04, 06, 08 e 10. Os animais do grupo controle receberam, nos mesmos dias e pela mesma via, $10 \mathrm{~mL} / \mathrm{kg}$ de água destilada.

No $12^{\circ}$ dia os animais foram sacrificados, foi colhido o tumor ascítico para mensuração de seu volume e contagem celular em câmara de Newbauer (item 3.4.11); realizou-se também a contagem das células medulares (item 3.4.7) e foi coletado material para histopatologia (fígado e rim), conforme descrito no item 3.4.9. A figura 3 representa o esquema de tratamento destes animais. 


\begin{tabular}{|c|c|c|c|c|c|c|c|c|}
\hline Animais & Dia 0 & Grupos & $\begin{array}{c}\text { Dia } \\
02\end{array}$ & $\begin{array}{c}\text { Dia } \\
04\end{array}$ & $\begin{array}{l}\text { Dia } \\
06\end{array}$ & $\begin{array}{c}\text { Dia } \\
08\end{array}$ & $\begin{array}{c}\text { Dia } \\
10\end{array}$ & $\begin{array}{c}\text { Dia } \\
12\end{array}$ \\
\hline & \multirow{4}{*}{ 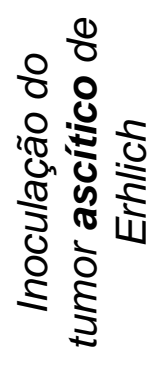 } & Controle & & & & & & $\not z$ \\
\hline & & $\begin{array}{c}\text { CIS } \\
1,0 \mathrm{mg} / \mathrm{kg}\end{array}$ & $\not$ & $\not$ & $\not$ & $\not$ & $\not$ & ar \\
\hline & & $\begin{array}{c}\text { CIS } \\
2,0 \mathrm{mg} / \mathrm{kg}\end{array}$ & $\phi$ & $\not$ & $\not$ & $\not$ & $\not$ & $\not 2$ \\
\hline & & $\begin{array}{c}\text { CIS } \\
3,0 \mathrm{mg} / \mathrm{kg}\end{array}$ & $\not$ & $\not$ & $\not$ & $\not$ & $\not$ & $\not 8$ \\
\hline
\end{tabular}

Figura 3: Esquema de tratamento de camundongos C57BI/6 inoculados com tumor ascítico de Ehrlich, que receberam 1,0;2,0 ou 3,0 $\mathrm{mg} / \mathrm{kg}$ de cisplatina, nos dias experimentais 2, 4, 6, 8 e 10. Os locais marcados com " $\phi$ " representam os dias em que os animais receberam os diferentes tratamentos de cisplatina. Os símbolos " $\mathrm{a}$ " representam a eutanásia dos animais

3.5.4 Experimento 4: Administração de 0,25; 0,5 e 0,75mg/kg de cisplatina em camundongos C57BI/6 inoculados com o tumor ascítico de Ehrlich: avaliação de celularidade de medula óssea, volume tumoral e contagem total de células tumorais

Foram empregados 34 animais machos C57BI/6. Inoculou-se nos camundongos, por via intraperitoneal, $2 \times 10^{7}$ células tumorais de Ehrlich (item 3.4.5). O dia da inoculação foi considerado como o dia 0 (zero) experimental; posteriormente, os camundongos foram divididos em quatro grupos, um controle e três grupos experimentais, $(n=7-9)$.

Os animais dos grupos experimentais foram tratados com cisplatina, por via intraperitoneal, nas doses de 0,$25 ; 0,5$ e $0,75 \mathrm{mg} / \mathrm{kg}$ (item 3.4.3) em dias alternados, ou seja, durante os dias experimentais $02 ; 04,06,08$ e 10. Nestes mesmos dias os animais do grupo controle receberam água destilada, pela mesma via, no volume de $10 \mathrm{~mL} / \mathrm{kg}$. 
No $12^{\circ}$ dia os animais foram submetidos à eutanásia, sendo colhido o tumor ascítico para mensuração de seu volume e contagem das células tumorais (item 3.4.11). Realizou-se também a contagem das células medulares (item 3.4.7) e foi coletado material para histopatologia (fígado e rim), como citado no item 3.4.9. A figura 4 representa o esquema de tratamento destes animais.

\begin{tabular}{|c|c|c|c|c|c|c|c|c|}
\hline Animais & Dia 0 & Grupos & $\begin{array}{l}\text { Dia } \\
02 \\
\end{array}$ & $\begin{array}{l}\text { Dia } \\
04 \\
\end{array}$ & $\begin{array}{l}\text { Dia } \\
06 \\
\end{array}$ & $\begin{array}{l}\text { Dia } \\
08 \\
\end{array}$ & $\begin{array}{l}\text { Dia } \\
10 \\
\end{array}$ & $\begin{array}{l}\text { Dia } \\
12 \\
\end{array}$ \\
\hline & \multirow{4}{*}{ 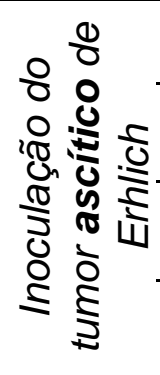 } & Controle & & & & & & $\not x$ \\
\hline & & $\begin{array}{c}\text { CIS } \\
0,25 \mathrm{mg} / \mathrm{kg}\end{array}$ & $\phi$ & $\not$ & $\not \varnothing$ & $\phi$ & $\not$ & $\not$ \\
\hline & & $\begin{array}{c}\text { CIS } \\
0,5 \mathrm{mg} / \mathrm{kg}\end{array}$ & $\phi$ & $\not$ & $\phi$ & $\phi$ & $\phi$ & $\not z$ \\
\hline & & $\begin{array}{c}\text { CIS } \\
0,75 \mathrm{mg} / \mathrm{kg}\end{array}$ & $\phi$ & $\phi$ & $\phi$ & $\phi$ & $\phi$ & $\not z$ \\
\hline
\end{tabular}

Figura 4: Esquema de tratamento de camundongos C57BI/6 inoculados com tumor ascítico de Ehrlich, que receberam 0,$25 ; 0,5$ ou $0,75 \mathrm{mg} / \mathrm{kg}$ de cisplatina, nos dias experimentais 2,4 , 6,8 e 10. Os locais marcados com " $\phi$ " representam os dias em que os animais receberam os diferentes tratamentos de cisplatina. Os símbolos " $\mathrm{a}$ " representam a eutanásia dos animais.

3.5.5 Experimento 5: Avaliação da sobrevida de camundongos C57BI/6, inoculados com tumor ascítico de Ehrlich, tratados com suainsonina ou RAF (resíduo aquoso final) da l.carnea administrando, concomitantemente ou não, a dose de $0,25 \mathrm{mg} / \mathrm{kg}$ de cisplatina

Utilizou-se 45 camundongos $\mathrm{C} 57 \mathrm{BI} / 6$. Os animais receberam por via intraperitoneal $2 \times 10^{7}$ células tumorais de Ehrlich, de acordo com o item 3.4.5. 
O dia 0 (zero) experimental foi considerado o dia da inoculação tumoral. Posteriormente, os animais foram separados em seis grupos, um grupo controle e cinco grupos experimentais, $(n=6-8)$. Os animais do grupo controle receberam água destilada por via intraperitoneal e por gavage (no volume de $10 \mathrm{~mL} / \mathrm{kg}$ ). Os animais dos grupos experimentais receberam os seguintes tratamentos:

> Cisplatina (Cis) por via intraperitoneal, na dose de $0,25 \mathrm{mg} / \mathrm{kg}$ (item 3.4.3) em dias alternados, ou seja, nos dias experimentais 02; 04, 06, 08 e 10;

> Suainsonina (Sw) por via intraperitoneal, na dose de $1 \mathrm{mg} / \mathrm{kg}$, duas vezes ao dia, entre os dias 2 e 11 (item 3.4.2);

RAF da l.carnea (RAF) por via oral, na concentração de $3 \mathrm{~g}$ de folhas secas/kg, entre os dias 2 e 11 (item 3.4.4);

$>$ Cisplatina e suainsonina (CisSw): os camundongos pertencentes a este grupo receberam a combinação dos tratamentos fornecidos aos animais dos grupos CIS e SW; e

Cisplatina e RAF da l.carnea (CisRAF): os camundongos pertencentes a este grupo receberam a combinação dos tratamentos fornecidos aos animais dos grupos CIS e RAF.

Todos os animais compartilharam o mesmo estresse decorrente dos diferentes tratamentos. Portanto, todos os animais receberam água destilada por gavage (à semelhança dos animais tratados com o RAF) e por via intraperitoneal duas ou três vezes ao dia (duas vezes ao dia à semelhança dos animais tratados com a suaninsonina e três vezes ao dia quando coincidiam os tratamentos com a cisplatina e com a suainsonina). 
A partir do $11^{\circ}$ dia não foi administrado nenhum tratamento aos animais; estes foram acompanhados diariamente para avaliação da evolução da ascite e das eventuais mortes, sendo estas contabilizadas para a análise estatística e para verificar a curva de sobrevida de cada animal. O esquema de tratamento esta exposto na figura 5.

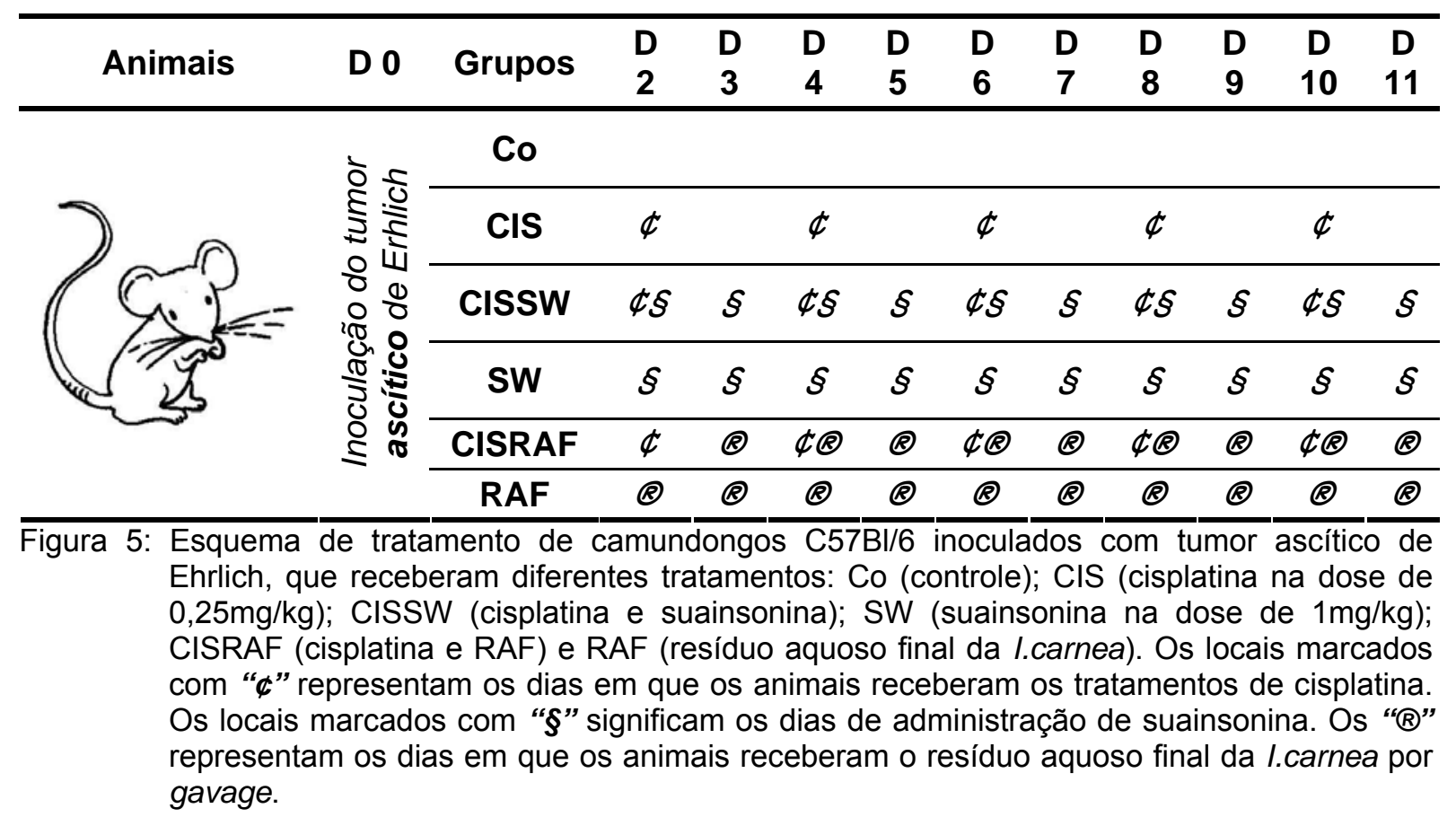


3.5.6 Experimento 6: Avaliação do crescimento tumoral de camundongos C57BI/6, inoculados com tumor ascítico de Ehrlich, tratados com suainsonina ou RAF (resíduo aquoso final) da l.carnea administrando, concomitantemente ou não, a dose de 0,25mg/kg de cisplatina

Foram empregados 81 animais machos C57BI/6. Inoculou-se nos camundongos, por via intraperitoneal, $2 \times 10^{7}$ células tumorais de Ehrlich (item 3.4.5) - com exceção aos animais pertencentes ao grupo branco. O dia da inoculação foi considerado o dia 0 (zero) experimental e, posteriormente, os camundongos foram separados em sete grupos: um branco, um controle e cinco grupos experimentais $(n=11-12)$.

Os animais do grupo controle receberam água destilada ou por via intraperitoneal e por gavage (no volume de $10 \mathrm{~mL} / \mathrm{kg}$ ). Já os camundongos pertencentes ao grupo branco, além de não receberem a inoculação do tumor ascítico de Ehrlich também não receberam qualquer tipo de tratamento.

Os animais dos grupos experimentais receberam os seguintes tratamentos:

Cisplatina (Cis) por via intraperitoneal na dose de $0,25 \mathrm{mg} / \mathrm{kg}$ (item 3.4.3) em dias alternados, ou seja, durante os dias experimentais 02; 04, 06, 08 e 10;

Suainsonina (Sw) por via intraperitoneal, na dose de $1 \mathrm{mg} / \mathrm{kg}$, duas vezes ao dia, entre os dias 2 e 11 (item 3.4.2);

RAF da l.carnea (RAF) na concentração de $3 \mathrm{~g}$ de folhas secas $/ \mathrm{kg}$, por via oral, entre os dias 2 e 11(item 3.4.4); 
Cisplatina e suainsonina (CisSw): os camundongos pertencentes a este grupo receberam a combinação dos tratamentos fornecidos aos animais dos grupos CIS e SW; e

Cisplatina e RAF da l.carnea (CisRAF): os camundongos pertencentes a este grupo receberam a combinação dos tratamentos fornecidos aos animais dos grupos CIS e RAF.

Todos os animais compartilharam o mesmo estresse decorrente dos diferentes tratamentos. Portanto todos os animais receberam água destilada por gavage (a semelhança dos animais tratados com o RAF) e por via intraperitoneal duas ou três vezes ao dia (duas vezes ao dia à semelhança dos animais tratados com a suaninsonina e três vezes ao dia quando coincidiam os tratamentos com a cisplatina e com a suainsonina.

No $12^{\circ}$ primeiro dia os animais foram sacrificados, sendo colhido o tumor ascítico para mensuração de seu volume, contagem das células tumorais e avaliação das células viáveis/inviáveis (item 3.4.11). Realizou-se também a avaliação no citômetro de fluxo, de acordo com o protocolo do item 3.4.12. Coletou-se também material do fígado, rim e baço para histopatologia (item 3.4.9). Além disso, foi realizada a análise sanguínea (avaliação do hemograma e da bioquímica sérica), conforme especificado no item 3.4.8. A figura 6 representa o esquema dde tratamento destes animais. 


\begin{tabular}{|c|c|c|c|c|c|c|c|c|c|c|c|c|c|}
\hline Animais & D 0 & Grupos & $\begin{array}{l}\text { D } \\
2\end{array}$ & $\begin{array}{l}\text { D } \\
3\end{array}$ & $\begin{array}{l}\text { D } \\
4\end{array}$ & $\begin{array}{l}\text { D } \\
5\end{array}$ & $\begin{array}{l}D \\
6\end{array}$ & $\begin{array}{l}\text { D } \\
7\end{array}$ & $\begin{array}{l}D \\
8\end{array}$ & $\begin{array}{l}\text { D } \\
9\end{array}$ & $\begin{array}{c}D \\
10\end{array}$ & $\begin{array}{c}D \\
11\end{array}$ & $\begin{array}{c}D \\
12\end{array}$ \\
\hline \multicolumn{13}{|c|}{$\mathrm{Br}$} & $\not x$ \\
\hline \multirow{6}{*}{2} & \multirow{6}{*}{ 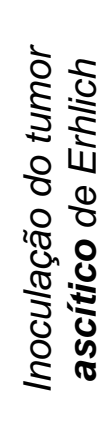 } & Co & & & & & & & & & & & $\not x$ \\
\hline & & CIS & $\phi$ & & $\phi$ & & $\phi$ & & $\not$ & & $\not$ & & tr \\
\hline & & CISSW & $\not \mathcal{S}$ & $\mathcal{S}$ & $\not \subset \mathcal{S}$ & $\mathcal{S}$ & $\not \mathcal{S}$ & $\mathcal{S}$ & $\not \mathcal{S}$ & $\mathcal{S}$ & $\not \mathcal{S}$ & $\mathcal{S}$ & tr \\
\hline & & sw & $\mathcal{S}$ & $\mathcal{S}$ & $\mathcal{S}$ & $\mathcal{S}$ & $\mathcal{S}$ & $\mathcal{S}$ & $\mathcal{S}$ & $\mathcal{S}$ & $\mathcal{S}$ & $\mathcal{S}$ & $\not R$ \\
\hline & & CISRAF & $\not$ & $\mathcal{B}$ & $\not \subset \mathbb{Q}$ & $\mathcal{B}$ & $\not \subset \otimes$ & $\mathcal{A}$ & $\not \subset \otimes$ & $\mathcal{B}$ & $\not \subset \otimes$ & $\mathbb{B}$ & $\not 2$ \\
\hline & & RAF & $\mathcal{A}$ & $\mathcal{Q}$ & $\mathcal{A}$ & $\mathcal{Q}$ & (B) & (Q) & (e) & (A) & (e) & $\mathbb{Q}$ & $\not x$ \\
\hline & $\begin{array}{l}\text { luema } \\
\text { lich, qu } \\
\text { dose de } \\
\text { / } / \mathrm{kg} \text { ); } \\
\text { cados } \\
\text { latina. } \\
\text { insonin } \\
\text { I da I.c }\end{array}$ & $\begin{array}{l}\text { de tratamen } \\
\text { e receberam } \\
\text { e 0,25mg/kg } \\
\text { ISRAF (cisp } \\
\text { com "\$" rep } \\
\text { Os locais } \\
\text { a. Os "®" re } \\
\text { arnea por ga } \\
\text { grupo branc }\end{array}$ & $\begin{array}{l}\text { CISS } \\
\text { ina } \\
\text { sent } \\
\text { arca } \\
\text { eser } \\
\text { age. }\end{array}$ & os & $\begin{array}{l}\text { dong } \\
\text { tame } \\
\text { olatin } \\
\text { e R/ } \\
\text { ias e } \\
\text { m } \\
\text { dias } \\
\text { oolos }\end{array}$ & & $\begin{array}{l}\mathrm{BI} / 6 \\
\mathrm{R} \text { (br } \\
\text { ainso } \\
\text { duo } \\
\text { os an } \\
\text { hifica } \\
\text { os a } \\
\text { prese }\end{array}$ & $\begin{array}{l}\text { locu } \\
\text { nco) } \\
\text { na); } \\
\text { quos } \\
\text { nais } \\
\text { os } \\
\text { imai }\end{array}$ & $\begin{array}{l}\text { ados } \\
\text { Co (c } \\
\text { SW (s } \\
\text { final } \\
\text { receb } \\
\text { dias } \\
\text { recel }\end{array}$ & 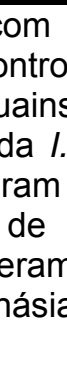 & $\begin{array}{l}\text { umo } \\
\text { e); } \\
\text { onine } \\
\text { arne tr } \\
\text { admi }\end{array}$ & $\begin{array}{l}\text { ascí } \\
\text { (cis } \\
\text { na d } \\
\text { Os } \\
\text { amer } \\
\text { strac } \\
\text { duo }\end{array}$ & $\begin{array}{r}\text { de } \\
\text { tina } \\
\text { de } \\
\text { cais } \\
\text { de } \\
\text { de } \\
\text { oso } \\
\text { Os }\end{array}$ \\
\hline
\end{tabular}


3.5.7 Experimento 7: Avaliação da celularidade da medula óssea esplênica de camundongos C57BI/6 inoculados com tumor ascítico de Ehrlich tratados com suainsonina administrando, concomitantemente ou não, a dose de $5 \mathrm{mg} / \mathrm{kg}$ de cisplatina

3.5.7.1 Teste preliminar: avaliação de celularidade da medula óssea de diferentes linhagens de camundongos

Foram utilizados 31 camundongos machos, livres de qualquer tipo de tratamento, das seguintes linhagens: Balb-c $(n=9)$; Swiss $(n=12)$ e C57BI/6 $(n=10)$. Os animais foram sacrificados, e as células medulares foram obtidas e contadas, conforme descrito no item 3.4.7.

3.5.7.2 Avaliação da celularidade da medula óssea e esplênica de camundongos C57BI/6 inoculados com tumor ascítico de Ehrlich tratados com suainsonina administrando, concomitantemente, ou não, a dose de $5 \mathrm{mg} / \mathrm{kg}$ de cisplatina

Foram utilizados 45 camundongos machos C57BI/6. Inoculou-se nos animais, por via intraperitoneal, $2 \times 10^{7}$ células tumorais de Ehrlich (no item 3.4.5) com exceção daqueles pertencentes ao grupo branco. O dia da inoculação foi considerado o dia 0 (zero) experimental; posteriormente os camundongos foram separados em cinco grupos: um branco, um controle e três grupos experimentais $(n=6-8)$. 
Os animais do grupo controle receberam água destilada ou por via intraperitoneal (no volume de $10 \mathrm{~mL} / \mathrm{kg}$ ). Já os camundongos pertencentes ao grupo branco, além de não receberem a inoculação do tumor ascítico de Ehrlich também não receberam qualquer tipo de tratamento.

Os animais dos grupos experimentais receberam os seguintes tratamentos:

Cisplatina (Cis) por via intraperitoneal na dose de $5,0 \mathrm{mg} / \mathrm{kg}$ (item 3.4.3) em dias alternados, ou seja, durante os dias experimentais 02; 04, 06, 08 e 10;

Suainsonina (Sw) por via intraperitoneal, na dose de $1 \mathrm{mg} / \mathrm{kg}$, duas vezes ao dia, entre os dias 2 e 11 (item 3.4.2); e

Cisplatina e suainsonina (CisSw): os camundongos pertencentes a este grupo receberam a combinação dos tratamentos fornecidos aos animais dos grupos CIS e Sw.

Todos os animais compartilharam o mesmo estresse decorrente dos diferentes tratamentos. Portanto, todos os animais receberam água destilada por via intraperitoneal duas ou três vezes ao dia (duas vezes ao dia à semelhança dos animais tratados com a suaninsonina e três vezes ao dia quando coincidiam os tratamentos com a cisplatina e com a suainsonina).

No $12^{\circ}$ primeiro dia os animais foram sacrificados, sendo colhido o tumor ascítico para mensuração de seu volume e contagem das células tumorais (item 3.4.11). Coletou-se também material do fígado, rim e baço para histopatologia (item 3.4.9). 
O baço dos camundongos foi colhido, pesado e seccionado aproximadamente ao meio. A primeira metade foi conservada em formol a $10 \%$ para avaliação histológica. A segunda metade foi pesada e processada para a contagem total da celularidade do órgão.

O esquema de tratamento destes animais esta exposto na figura 7.

\begin{tabular}{|c|c|c|c|c|c|c|c|c|c|c|c|c|c|}
\hline Animais & D 0 & Grupos & $\begin{array}{l}D \\
2\end{array}$ & $\begin{array}{l}\text { D } \\
3\end{array}$ & $\begin{array}{l}D \\
4\end{array}$ & $\begin{array}{l}D \\
5\end{array}$ & $\begin{array}{l}D \\
6\end{array}$ & $\begin{array}{l}\text { D } \\
7\end{array}$ & $\begin{array}{l}\text { D } \\
8\end{array}$ & $\begin{array}{l}\text { D } \\
9\end{array}$ & $\begin{array}{c}D \\
10\end{array}$ & $\begin{array}{c}D \\
11\end{array}$ & $\begin{array}{c}D \\
12\end{array}$ \\
\hline \multicolumn{13}{|c|}{$\mathrm{Br}$} & $2 x$ \\
\hline \multirow{4}{*}{\multicolumn{2}{|c|}{ 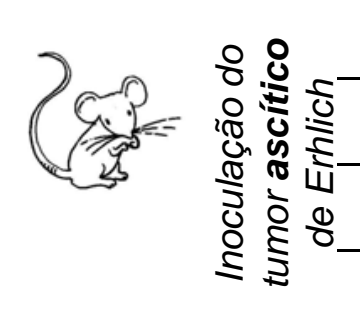 }} & Co & & & & & & & & & & & $2 x$ \\
\hline & & CIS & $\not$ & & $\not$ & & $\phi$ & & $\not$ & & $\not$ & & $\not x$ \\
\hline & & CISSW & $\not \mathcal{S}$ & $\mathcal{S}$ & $\not \mathcal{S}$ & $\mathcal{S}$ & $\not \mathcal{S}$ & $\mathcal{S}$ & $\not \mathcal{S}$ & $\mathcal{S}$ & $\not \mathcal{S}$ & $\mathcal{S}$ & $x$ \\
\hline & & sw & $\mathcal{S}$ & $\mathcal{S}$ & $\mathcal{S}$ & $\mathcal{S}$ & $\mathcal{S}$ & $\mathcal{S}$ & $\mathcal{S}$ & $\mathcal{S}$ & $\mathcal{S}$ & $\mathcal{S}$ & $\not x$ \\
\hline \multicolumn{14}{|c|}{ 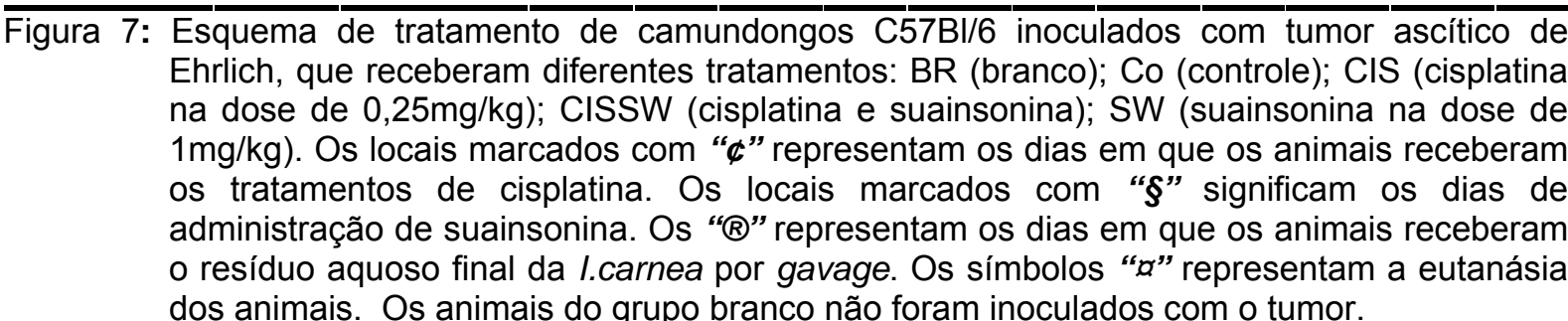 } \\
\hline
\end{tabular}




\subsection{Análise Estatística}

Para análise dos dados foi utilizado o programa estatístico GraphPad Prism 5.00® (GraphPad Software, Inc., San Diego, CA, USA). Para verificar a homocedasticidade dos dados utilizou-se o teste de Bartlet. Para dados paramétricos, foi utilizada a análise de variância ANOVA seguida do teste de Dunnett's para comparação dos grupos experimentais com o grupo controle. Para dados não paramétricos, utilizou-se o teste de Kruskal-Wallis seguido do teste de Dunn's. Nos estudos relacionados à curva de sobrevida foi utilizado o teste de Logrank. Foram consideradas significativas as análises que apresentaram nível de significância $p<0,05$. Os dados estão expressos como média \pm erro padrão e os dados de porcentagem estão expressos como mediana (mínimo - máximo). 


\section{RESULTADOS}




\section{RESULTADOS}

4.1 Experimento 1: Administração de 0,5; 1,0 e 1,5mg/kg de cisplatina em camundongos C57BL/6 inoculados com tumor sólido de Ehrlich (TSE): avaliação das doses de cisplatina e do modelo experimental

Quando se avaliou os dados referentes à contagem total de células medulares dos camundongos tratados com diferentes doses de cisplatina, não foi possível observar diferenças estatísticas entre os grupos (KruskalWallis $-\mathrm{KW}=2,999, \mathrm{p}=0,3918$ - Tabela 2 e figura 8).

Em relação ao hematócrito, observou-se que os animais dos grupos que receberam as doses de $1,0 \mathrm{mg} / \mathrm{kg}$ e $1,5 \mathrm{mg} / \mathrm{kg}$ de cisplatina apresentaram redução significativa deste parâmetro quando comparados ao grupo controle (Kruskal-Wallis - $K W=16,030, p=0,0011$ - pós teste de Dunn's - $p<0,05)$. Os resultados do hematócrito dos diferentes grupos são apresentados na tabela 3 e na figura 9.

Em relação ao peso tumoral (ANOVA, $F=2,289 ; d f=3 / 24 ; p=0,1053$ pós teste de Dunnett's $p<0,05$ ) e volume tumoral (ANOVA, $F=2,920$; $d f=3 / 24 ; p=0,0546$ - pós teste de Dunnett's $p<0,05$ ), foi possível notar reduções significantes destes parâmetros entre o grupo tratado com a cisplatina, na dose de $1,5 \mathrm{mg} / \mathrm{kg}$, quando comparado ao grupo controle. Estes resultados são apresentados na tabela 4 e na figura 10. 
A figura 11 ilustra as diferenças entre as massas tumorais de animais do grupo controle e o grupo tratado com a maior dose de cisplatina $(1,5 \mathrm{mg} / \mathrm{kg})$; é possível notar o tamanho reduzido da massa tumoral do animal tratado quando comparado com o animal do grupo controle.

Os quadros 1, 2 e 3 apresentam as descrições histopatológicas dos tecidos: hepático, renal e da massa tumoral de camundongos do grupo controle e dos grupos tratados com as diferentes doses de cisplatina. Estes dados sugerem a inexistência de diferenças histopatológicas entre os grupos estudados. 
Tabela 2: Contagem total de células da medula óssea de camundongos que receberam 0,5 ; 1,0 ou $1,5 \mathrm{mg} / \mathrm{kg}$ de cisplatina, nos dias experimentais $2,4,6,8$ e 10

\begin{tabular}{|c|c|c|c|c|}
\hline & \multirow{2}{*}{$\begin{array}{c}\text { Controle } \\
(n=5)\end{array}$} & \multicolumn{3}{|c|}{ Cisplatina } \\
\hline & & $\begin{array}{c}0,5 \mathrm{mg} / \mathrm{kg} \\
(\mathrm{n}=5)\end{array}$ & $\begin{array}{c}1,0 \mathrm{mg} / \mathrm{kg} \\
(\mathrm{n}=5)\end{array}$ & $\begin{array}{c}\text { 1,5mg.kg } \\
(n=5)\end{array}$ \\
\hline $\begin{array}{l}\text { Número total de } \\
\text { células da medulla } \\
\text { óssea }\left(10^{6}\right)\end{array}$ & $\begin{array}{r}35,8 \\
\pm 0,39\end{array}$ & $\begin{array}{r}41,8 \\
\pm 1,56 \\
\end{array}$ & $\begin{array}{c}30,1 \\
\pm 1,36\end{array}$ & $\begin{array}{c}31,0 \pm \\
2,24\end{array}$ \\
\hline
\end{tabular}

São apresentadas as médias e os respectivos erros padrões (Kruskal-Wallis, $p>0,05$ quando comparado com o grupo controle).

\section{Contagem total das células da medula óssea}

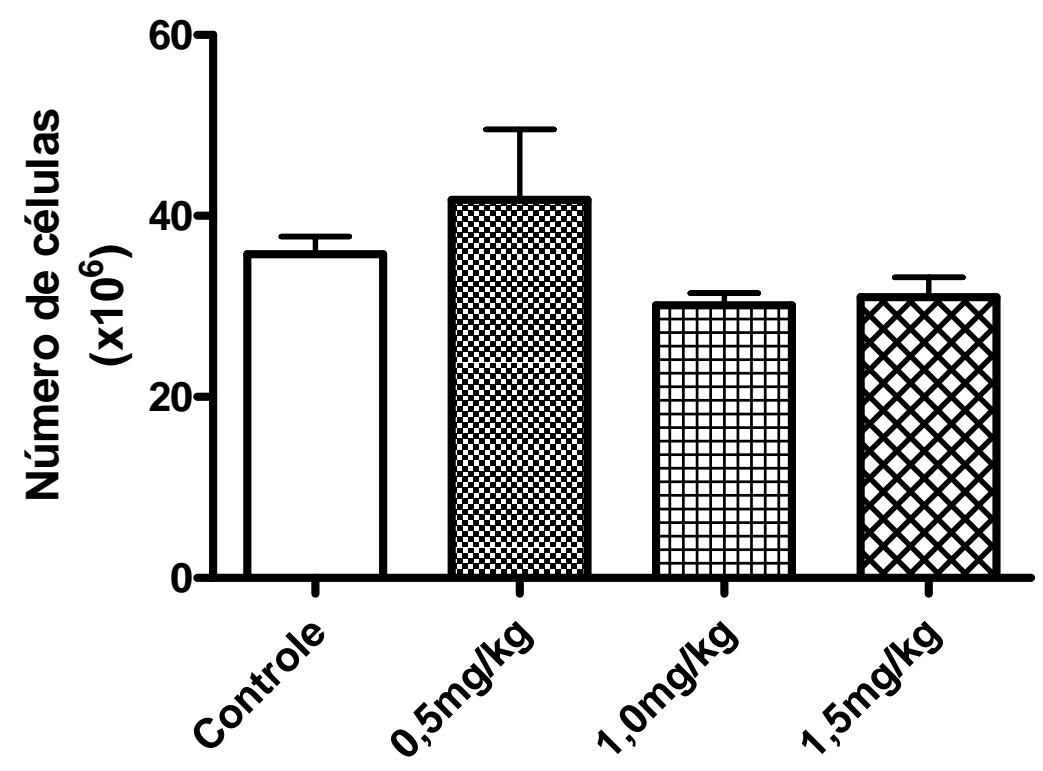

Figura 8: Contagem total de células da medula óssea de camundongos que receberam 0,$5 ; 1,0$ ou 1,5mg/kg de cisplatina, nos dias experimentais 2, 4, 6, 8 e 10. São apresentadas as médias e os respectivos erros padrões ( $n=5$ por grupo) (Kruskal-Wallis, $p>0,05$ ) 
Tabela 3: Valores de hematócrito de camundongos tratados com 0,5; 1,0 e 1,5mg/kg de cisplatina, nos dias experimentais $2,4,6,8$ e 10

\begin{tabular}{|ccccc|}
\hline & \multirow{2}{*}{$\begin{array}{c}\text { Controle } \\
(\mathbf{n}=5)\end{array}$} & $\begin{array}{c}\mathbf{0 , 5 m g / k g} \\
(\mathbf{n}=6)\end{array}$ & $\begin{array}{c}\mathbf{1 , 0 m g / k g} \\
(\mathbf{n}=5)\end{array}$ & $\begin{array}{c}\mathbf{1 , 5} \mathbf{m g} / \mathbf{k g} \\
(\mathbf{n}=6)\end{array}$ \\
\hline $\begin{array}{c}\text { Hematócrito } \\
(\%)\end{array}$ & $47,60 \pm 0,68$ & $47,80 \pm 0,31$ & $44,40 \pm 0,51^{\star}$ & $44,33 \pm 0,33^{\star}$ \\
\hline
\end{tabular}

São apresentadas as médias e os erros padrões (Kruskal-Wallis - pós teste de Dunn's *p<0,05, quando comparado com o grupo controle)

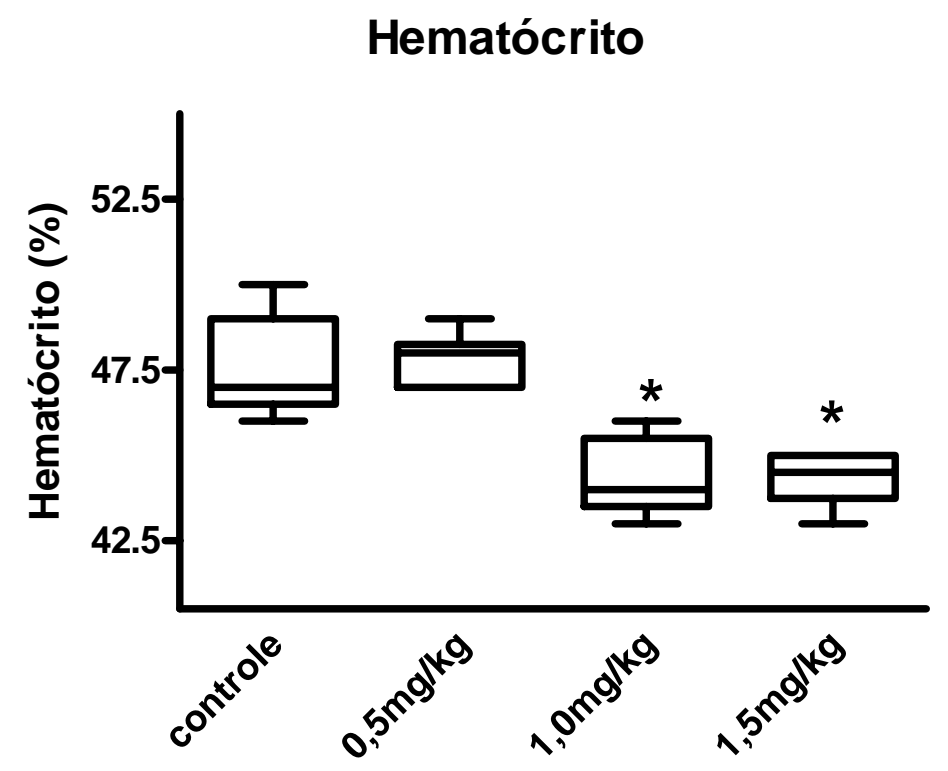

Figura 9: Valores de hematócrito de camundongos tratados com 0,5; 1,0 e 1,5mg/kg de cisplatina, nos dias experimentais 2, 4, 6, 8 e 10. São apresentadas as medianas, as médias (traços horizontais dentro das caixas) e os limites superiores e inferiores ( $\mathrm{n}=5-6$ por grupo) (Kruskal-Wallis - pós teste de Dunn's * $\mathrm{p}<0,05$, quando comparado com o grupo controle)

Tabela 4: Peso e volume tumoral de camundongos tratados com 0,$5 ; 1,0$ e 1,5mg/kg de cisplatina, nos dias experimentais $2,4,6,8$ e 10

\begin{tabular}{|ccccc|}
\hline & $\begin{array}{c}\text { Controle } \\
(\mathbf{n}=\mathbf{9})\end{array}$ & $\begin{array}{c}\mathbf{0 , 5 m g / k g} \\
(\mathbf{n}=6)\end{array}$ & $\begin{array}{c}\mathbf{1 , 0 m g} / \mathbf{k g} \\
(\mathbf{n = 5})\end{array}$ & $\begin{array}{c}\mathbf{1 , 5 m g} / \mathbf{k g} \\
(\mathbf{n}=7)\end{array}$ \\
\hline $\begin{array}{c}\text { Peso tumoral } \\
(\mathbf{g})\end{array}$ & $0,681 \pm 0,088$ & $0,579 \pm 0,105$ & $0,618 \pm 0,071$ & $0,387 \pm 0,071^{*}$ \\
\hline $\begin{array}{c}\text { Volume } \\
\text { tumoral } \\
\left.\mathbf{( m m}^{3}\right)\end{array}$ & $31900 \pm 4711$ & $25494 \pm 5141$ & $29736 \pm 4405$ & $15038 \pm 3950^{*}$ \\
\hline
\end{tabular}

São apresentadas as medias e os respectivos erros padrões (ANOVA - pós teste de Dunnett's, ${ }^{*} \mathrm{p}>0,05$, quando comparado com o grupo controle). 


\section{Peso tumoral}

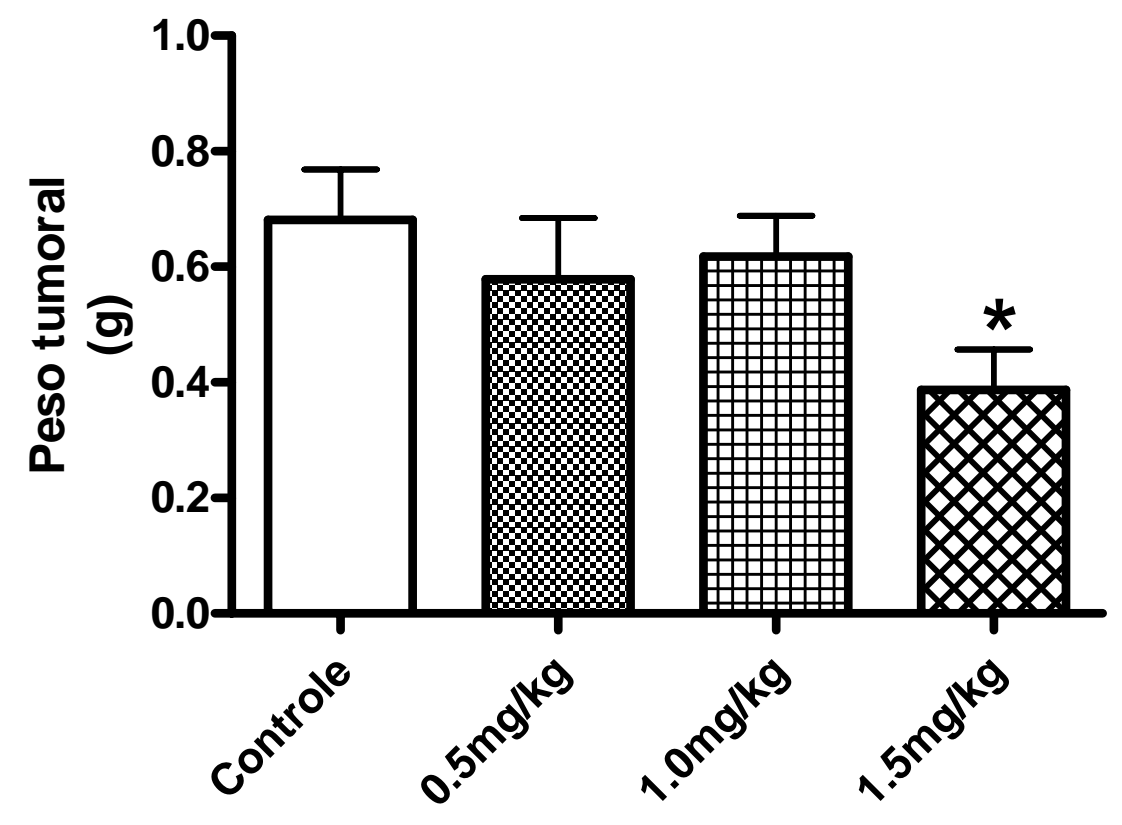

Volume tumoral

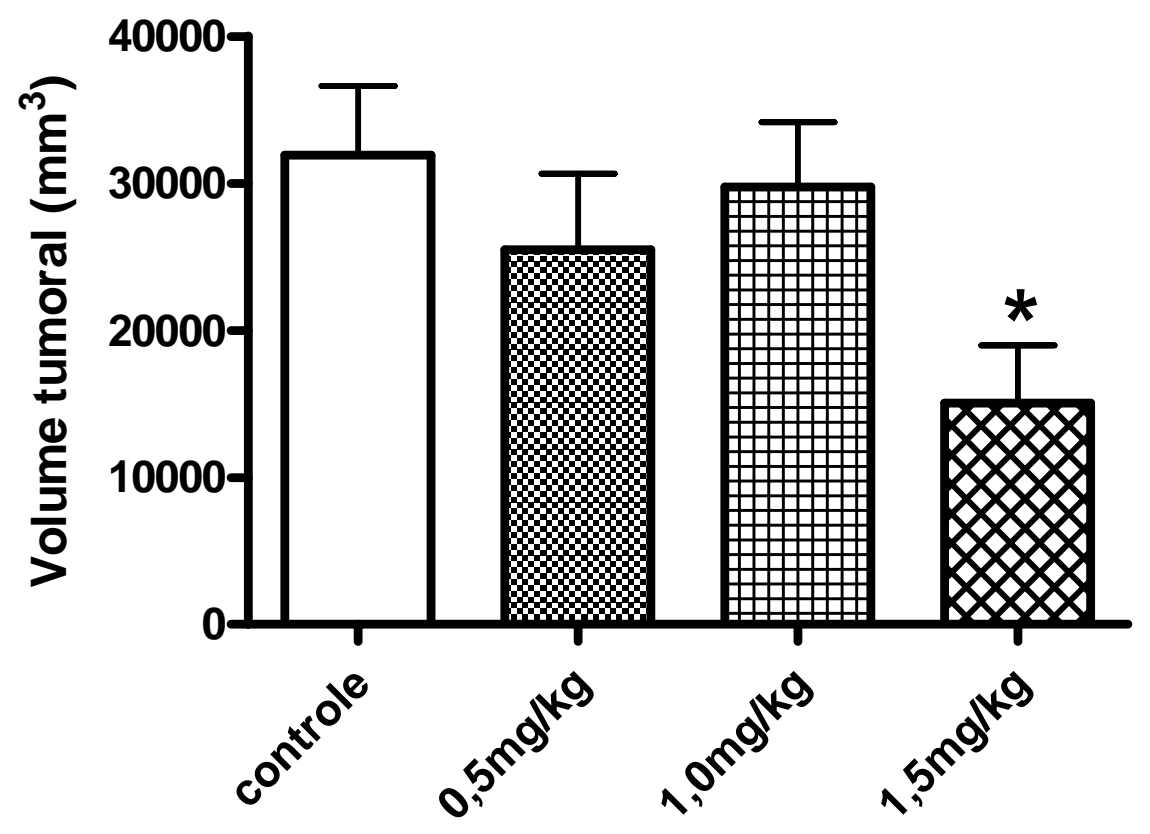

Figura 10: Peso e volume tumorais de camundongos tratados com 0,5; 1,0 e 1,5mg/kg de cisplatina, nos dias experimentais 2, 4, 6, 8 e 10. São apresentadas as médias e os respectivos erros padrões ( $n=5-9$ por grupo) (ANOVA - pós teste de Dunnett's, $p>0,05$, quando comparado com o grupo controle) 

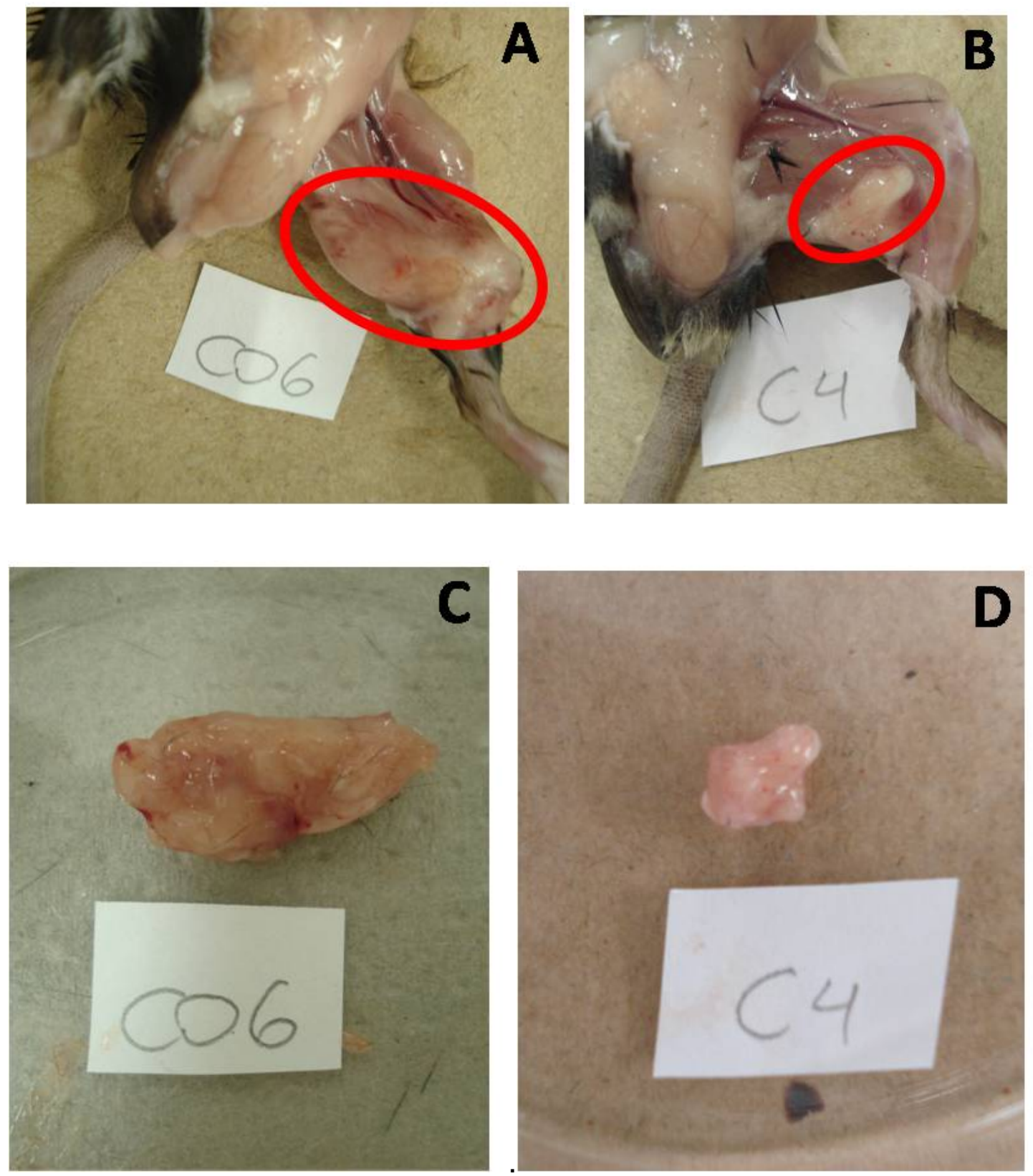

Figura 11: Fotografias de camundongo do grupo controle ( $\boldsymbol{A}$ e $\boldsymbol{C}$ ) e do grupo tratado com $1,5 \mathrm{mg} / \mathrm{kg}$ de cisplatina (B e D). Em A e B nota-se a massa tumoral in situ dos animais, circulada em vermelho. Em C e D nota-se o tumor isolado destes mesmos camundongos 


\begin{tabular}{|c|c|}
\hline Grupos & Descrição histopatológica de tecido hepático \\
\hline Controle & $\begin{array}{l}\text { Quadro histológico dentro do padrão da normalidade; } \\
\text { Discreto infiltrado de células inflamatórias, de caráter } \\
\text { multifocal ( } 3 \text { focos por fragmento histológico); } \\
>\text { Algumas figuras de mitose. }\end{array}$ \\
\hline $\begin{array}{c}0,5 \mathrm{mg} / \mathrm{kg} \\
\text { cisplatina }\end{array}$ & $\begin{array}{l}\text { Histologicamente semelhante ao grupo controle; } \\
\text { Número maior de focos de células inflamatórias (10-15 } \\
\text { focos por fragmento). }\end{array}$ \\
\hline $\begin{array}{l}1,0 \mathrm{mg} / \mathrm{kg} \\
\text { cisplatina }\end{array}$ & $\begin{array}{l}\text { Histologicamente semelhante ao grupo controle; } \\
\text { Maior número de focos de células inflamatórias } \\
\text { (aproximadamente } 15 \text { focos por fragmento). }\end{array}$ \\
\hline $\begin{array}{l}1,5 \mathrm{mg} / \mathrm{kg} \\
\text { cisplatina }\end{array}$ & $\begin{array}{l}>\text { Histologicamente semelhante ao grupo controle; } \\
\text { focos por fragmento); } \\
>\text { Aumento do número de figuras de mitose (0-2 mitoses } \\
\text { por campo em aumento de } 40 \text { vezes); } \\
>\text { Aumento do número de células binucleadas (entre } 3 \text { e } 6 \\
\text { células por campo, em aumento de } 40 \text { vezes). }\end{array}$ \\
\hline
\end{tabular}

Quadro 1: Descrição histopatológica de tecido hepático de camundongos do grupo controle e dos grupos tratados com 0,$5 ; 1,0$ e 1,5mg/kg de cisplatina, nos dias experimentais 2 , $4,6,8$ e 10 


\begin{tabular}{|c|c|}
\hline Grupos & Descr \\
\hline Controle & $\begin{array}{l}\text { Túbulos proximais com discreta degeneração } \\
\text { citoplasmática; } \\
>\text { Discreta nefrose multifocal; } \\
>\text { Preservação da arquitetura histológica e glomérulos } \\
\text { livres de processos patológicos. }\end{array}$ \\
\hline & $\begin{array}{l}>\text { Nefrose discreta; } \\
>\text { Presença de cilindros hialinos em túbulos distais; } \\
>\text { Diminuição da segmentação glomerular; } \\
>\text { Discreto quadro de glomerulonefrite membranoproli- } \\
\text { ferativa multifocal segmentar; } \\
>\text { Demais relações histológicas semelhantes ao grupo } \\
\text { controle. }\end{array}$ \\
\hline & $\begin{array}{l}>\text { Nefrose discreta; } \\
>\text { Presença de cilindros hialinos em túbulos distais; } \\
>\text { Discreto quadro de glomerulonefrite membranoproli- } \\
\text { ferativa multifocal segmentar; } \\
>\text { Demais relações histológicas semelhantes ao grupo } \\
\text { controle. }\end{array}$ \\
\hline $\begin{array}{l}1,5 \mathrm{mg} / \mathrm{kg} \\
\text { cisplatin }\end{array}$ & $\begin{array}{l}\text { Nefrose discreta; } \\
>\text { Rara presença de cilindros hialinos em túbulos distais; } \\
>\text { Discreta nefrite intersticial linfoplasmocítica multifocal; } \\
\text { Discreto quadro de glomerulonefrite membranoproli- } \\
\text { ferativa multifocal segmentar; } \\
>\text { Demais relações histológicas semelhantes ao grupo } \\
\text { controle. }\end{array}$ \\
\hline
\end{tabular}

Quadro 2: Descrição histopatológica de tecido renal de camundongos do grupo controle e dos grupos tratados com 0,$5 ; 1,0$ e 1,5mg/kg de cisplatina, nos dias experimentais 2, 4, 6,8 e 10 


\begin{tabular}{|c|c|}
\hline & Des \\
\hline $\begin{array}{c}\text { Controle } \\
\begin{array}{c}0,5 \mathrm{mg} / \mathrm{kg} \\
\text { cisplatina }\end{array} \\
\begin{array}{c}1,0 \mathrm{mg} / \mathrm{kg} \\
\text { cisplatina }\end{array} \\
\begin{array}{l}1,5 \mathrm{mg} / \mathrm{kg} \\
\text { cisplatina }\end{array}\end{array}$ & $\begin{array}{l}\text { Proliferação sólida de células poligonais basofílicas, em } \\
\text { região muscular; } \\
\text { Células com núcleos ovais/arredondados, } \\
\text { apresentando de } 1 \text { a } 3 \text { nucléolos; } \\
>\text { Pleomorfismo e índice mitótico elevado; } \\
>\text { Crescimento infiltrado nos tecidos musculares; } \\
>\text { Formação de grandes áreas cavitárias, compostas por } \\
\text { células necróticas e degeneradas; } \\
>\text { Na periferia do nódulo neoplásico observa-se infiltrado } \\
\text { inflamatório linfoplasmocitário (de moderado a severo), } \\
\text { associados a focos hemorrágicos. Tumor com estroma } \\
\text { delicado. }\end{array}$ \\
\hline & 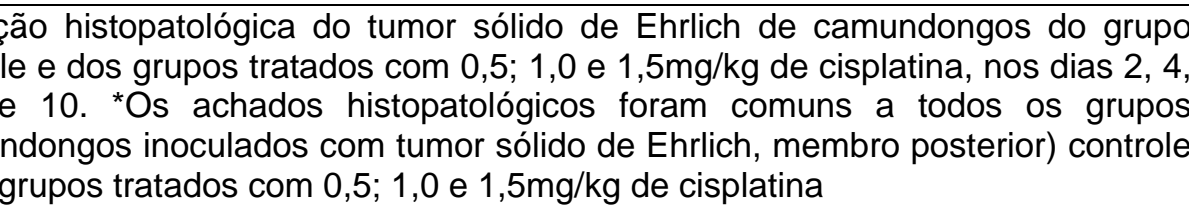 \\
\hline
\end{tabular}


4.2 Experimento 2: Inoculação de $1 \times 10^{6} ; 1 \times 10^{7}$ e $2 \times 10^{7}$ células tumorais ascíticas de Ehrlich em camundongos C57BL/6: avaliação da curva de sobrevida

$\mathrm{Na}$ avaliação da sobrevida de camundongos C57Bl/6 inoculados com diferentes concentrações de células tumorais ascíticas de Ehrlich, o teste de Logrank evidenciou diferenças significantes entre os grupos estudados. Os animais do grupo TAE106, inoculados com $1 \times 10^{6}$ células, sobreviveram por mais tempo, em média 33 dias, apresentando diferença estatística quando comparados com os animais do grupo TAE207, inoculados com $2 \times 10^{7}$ células, que apresentaram uma média 16 dias de sobrevida (Logrank - Qui ${ }^{2}=14,69$; $\mathrm{p}=0,0006)$. Os animais inoculados com a dose intermediária $\left(1 \times 10^{7}\right)$, pertencentes ao grupo TAE107, apresentaram em média uma sobrevida de 22 dias. A figura 12 ilustra esses dados.

\section{Curva de Sobrevida de diferentes doses de TAE}

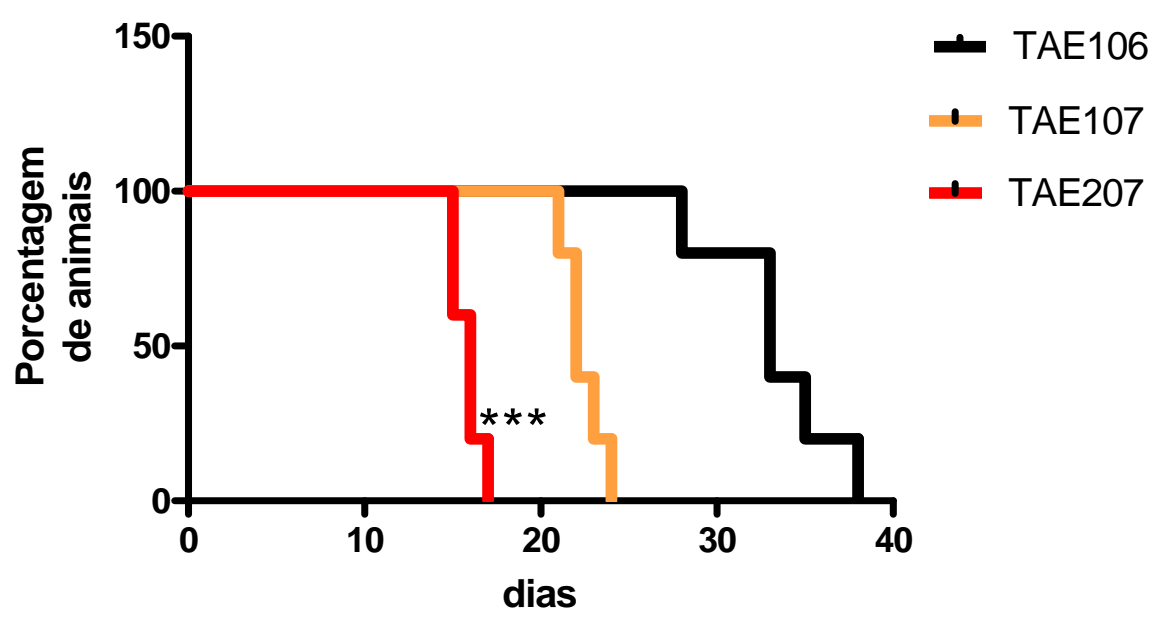

Figura 12: Curva de sobrevida de camundongos C57BL/6 inoculados com diferentes concentrações de células tumorais de Ehrlich: $1 \times 10^{6}$ (TAE106); $1 \times 10^{7}$ (TAE107) e $2 \times 10^{7}$ (TAE207) células tumorais ( $n=5$ por grupo). (Teste de Logrank, ${ }^{\star \star \star} P<0,001$, quando comparado com o grupo TAE 106) 
4.3 Experimento 3: Administração de 1,0; 2,0 e 3,0mg/kg de cisplatina em camundongos C57BI/6 inoculados com tumor ascítico de Ehrlich: avaliação de sobrevida, celularidade de medula óssea, volume tumoral e contagem total de células tumorais

\subsubsection{Avaliação de sobrevida}

$\mathrm{Na}$ análise da curva de sobrevida foi possível evidenciar maior tempo de sobrevida dos animais dos grupos tratados com 1,0mg/kg e 2,0mg/kg de cisplatina, quando comparados àqueles do grupo controle (Logrank, $\mathrm{p}<0,001)$. Por outro lado, os animais do grupo tratado com 3,0mg/kg de cisplatina não apresentaram diferenças estatísticas quando comparados aos animais do grupo controle (Logrank, $\mathrm{p}=0,2226)$. A figura 13 ilustra esses dados.

\section{Curva de sobrevida}

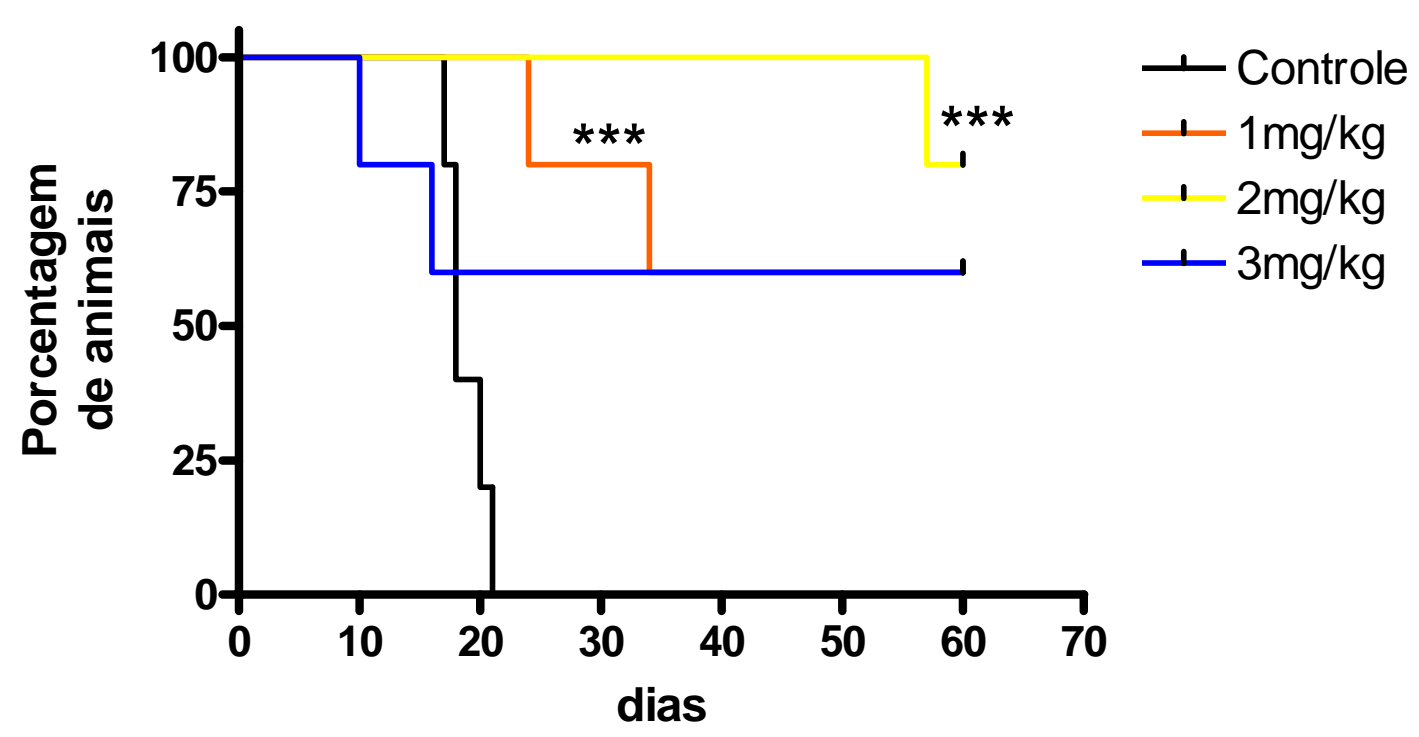

Figura 13: Curva de sobrevida de camundongos C57BL/6 inoculados com tumor ascítico de Ehrlich, pertencentes ao grupo controle e tratados com 1,$0 ; 2,0$ e $3,0 \mathrm{mg} / \mathrm{kg}$ de cisplatina ( $\mathrm{n}=5$ por grupo). (teste de Logrank, ${ }^{\star} \mathrm{p}<0,001$ quando comparado com o grupo controle) 
4.3.2 Celularidade de medula óssea, volume tumoral e contagem total de células tumorais

Em relação à celularidade da medula óssea, observou-se uma diminuição significante deste parâmetro em animais dos grupos experimentais quando comparados àqueles do grupo controle (ANOVA - $F=9,221 ; d f=3 / 23 ; p=0,0003$ pós teste de Dunnett's - $p<0,001)$ - Tabela 5 e figura 14.

Os números de células tumorais por $\mathrm{mL}$ dos animais dos grupos tratados com 1,0 e 2,0mg/kg de cisplatina não mostraram diferenças significantes em relação àqueles do grupo controle (Kruskal-Wallis - KW=10,410; $p=0,0154$ - pós teste de Dunn's $-p<0,05)$. Vale ressaltar que os animais do grupo tratado com $3,0 \mathrm{mg} / \mathrm{kg}$ de cisplatina não desenvolveram o tumor ascítico, portanto, foi impossível mensurar o número de células por mL - Tabela 6 e figura 15.

Em relação ao volume tumoral (ANOVA - $F=108,0 ; d f=3 / 28 ; p<0,0001$. pós teste de Dunnett's - $\mathrm{p}<0,001$ ) e a contagem total destas células (ANOVA $F=15,670 ; d f=3 / 28 ; p<0,0001$ - pós teste de Dunnett's $-p<0,001)$, observou-se redução significante em todos os animais dos grupos experimentais, quando comparados com aqueles do grupo controle. Deve ser salientado que não foi possível a mensuração tanto do volume quanto da contagem total destas células dos camundongos tratados com 3,0mg/kg de cisplatina, uma vez que estes animais não desenvolveram o tumor. A tabela 6 e figura 16 ilustram esses dados.

Os quadros 4 e 5 apresentam as descrições histopatológicas dos tecidos hepático e renal de camundongos inoculados com o tumor ascítico de Ehrlich pertencentes ao grupo controle e aos grupos tratados com as diferentes doses de cisplatina. 
No fígado dos animais do grupo controle foi observada, em torno da cápsula hepática, a presença de células neoplásicas e de infiltrado inflamatório; além de raros focos neoplásicos no parênquima do órgão. Nos animais dos grupos experimentais notou-se redução da ocorrência destes achados na medida em que se aumenta a dose de cisplatina. É importante ressaltar que os animais tratados com 3,0mg/kg de cisplatina não apresentaram células neoplásicas ao redor da cápsula hepática, nem infiltrado inflamatório.

Nos rins dos animais do grupo controle, em torno da cápsula renal, observou-se a presença de células neoplásicas e de infiltrado inflamatório, porém foi mantida a arquitetura histológica do órgão e os glomérulos mostravam-se livres de processos patológicos, caracterizando um tecido dentro do padrão da normalidade. Nos animais dos grupos experimentais, na medida em que se aumentou a dose de cisplatina, observou-se redução da ocorrência das células neoplásicas aderidas à cápsula renal, porém, notou-se um aumento gradativo da presença de lesões renais, como, por exemplo, congestão, focos hemorrágicos, nefrose, cilindros hialinos, proteinúria em túbulos proximais, células mesoteliais reativas, diminuição da segmentação glomerular e discreto quadro de glomerulonefrite membranoproliferativa multifocal segmentar. 
Tabela 5: Celularidade de medula óssea de camundongos C57BL/6 inoculados com tumor ascítico de Ehrlich e tratados e tratados com 1,0; 2,0 e 3,0 mg/kg de cisplatina, nos dias 2, 4, 6, 8 e 10

\begin{tabular}{|c|c|c|c|c|}
\hline & \multirow{2}{*}{$\begin{array}{c}\text { Controle } \\
(n=7)\end{array}$} & \multicolumn{3}{|c|}{ Cisplatina } \\
\hline & & $\underset{(\mathrm{n}=7)}{1,0 \mathrm{mg} / \mathrm{kg}}$ & $\underset{(n=8)}{2,0 \mathrm{mg} / \mathrm{kg}}$ & $\begin{array}{c}3,0 \mathrm{mg} / \mathrm{kg} \\
(\mathrm{n}=5)\end{array}$ \\
\hline 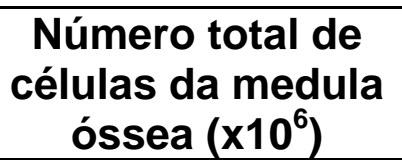 & $\begin{array}{l}50,89 \\
\pm 4,89\end{array}$ & $\begin{array}{c}36,43 \\
\pm 1,80 * \star\end{array}$ & $\begin{array}{c}29,38 \\
\pm 2,35^{\star \star \star}\end{array}$ & $\begin{array}{c}33,25 \\
\pm 2,42^{\star \star}\end{array}$ \\
\hline
\end{tabular}

São apresentadas as médias e os respectivos erros padrões (ANOVA - pós teste de Dunnett's ${ }^{\star \star} p<0,01 \mathrm{e}^{\star \star \star} \mathrm{p}<0,001$, quando comparado com o grupo controle).

Tabela 6: Volume, número total de células tumorais e número de células tumorais por $\mathrm{mL}$ de camundongos inoculados com tumor ascítico de Ehrlich e tratados com 1,0; 2,0 e 3,0mg/kg de cisplatina, nos dias 2, 4, 6, 8 e 10

\begin{tabular}{|c|c|c|c|c|}
\hline & \multirow{2}{*}{$\begin{array}{c}\text { Controle } \\
(n=9)\end{array}$} & \multicolumn{3}{|c|}{ Cisplatina } \\
\hline & & $\underset{(n=6)}{1,0 \mathrm{mg} / \mathrm{kg}}$ & $\begin{array}{c}2,0 \mathrm{mg} / \mathrm{kg} \\
(\mathrm{n}=5)\end{array}$ & $\begin{array}{c}3,0 \mathrm{mg} / \mathrm{kg} \\
(\mathrm{n}=7)\end{array}$ \\
\hline $\begin{array}{c}\text { Número de } \\
\text { células } \\
\text { tumorais por } \mathrm{mL} \\
\left(\times 10^{7}\right) \\
\end{array}$ & $\begin{array}{l}11,86 \\
\pm 2,55\end{array}$ & $\begin{array}{l}12,36 \\
\pm 4,97\end{array}$ & $\begin{array}{c}6,44 \\
\pm 2,83\end{array}$ & $\begin{array}{c}0,0 \\
\pm 0,0^{\#}\end{array}$ \\
\hline $\begin{array}{c}\text { Volume tumoral } \\
(\mathrm{mL})\end{array}$ & $\begin{array}{l}11,89 \\
\pm 0,88 \\
\end{array}$ & $\begin{array}{c}0,94 \\
\pm 0,45^{\star \star \star} \\
\end{array}$ & $\begin{array}{c}0,84 \\
\pm 0,42^{\star \star \star} \\
\end{array}$ & $\begin{array}{c}0,0 \\
\pm 0,00 \text { *** } \\
\end{array}$ \\
\hline $\begin{array}{l}\text { Número total de } \\
\text { células tumorais } \\
\left(\times 10^{7}\right)\end{array}$ & $\begin{array}{c}144,3 \\
\pm 32,84\end{array}$ & $\begin{array}{c}22,19 \\
\pm 12,39^{\star \star \star}\end{array}$ & $\begin{array}{c}11,13 \\
\pm 5,04^{\star \star \star}\end{array}$ & $\begin{array}{c}0,0 \\
\pm 0,0^{\star \star \star *}\end{array}$ \\
\hline
\end{tabular}

São apresentadas as médias e os respectivos erros padrões (ANOVA - pós teste de Dunnett's-*** $p<0,001$, quando comparado com o grupo controle) (Kruskal Wallis - pós teste de de Dunn's ${ }^{\#} p<0,05$, quando comparado com o grupo controle). 


\section{Contagem total das células da medula óssea}

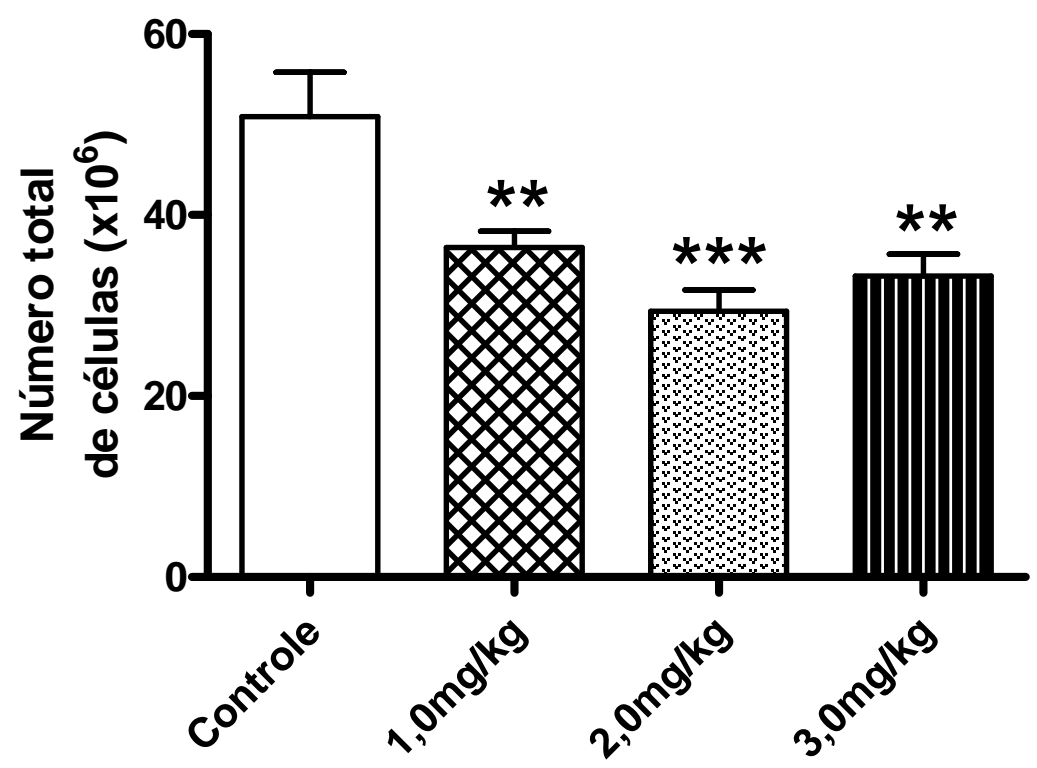

Figura 14: Celularidade de medula óssea de camundongos C57BL/6 inoculados com tumor ascítico de Ehrlich e tratados com diferentes doses de cisplatina, nos dias 2, 4, 6, 8 e 10. São apresentadas as médias e os respectivos erros padrões ( $n=5-8$ por grupo) (ANOVA - pós teste de Dunnett's - ${ }^{* *} \mathrm{p}<0,01^{* \star *} \mathrm{p}<0,001$, quando commparado com o grupo controle)

\section{Número de células tumorais por $\mathrm{mL}$}

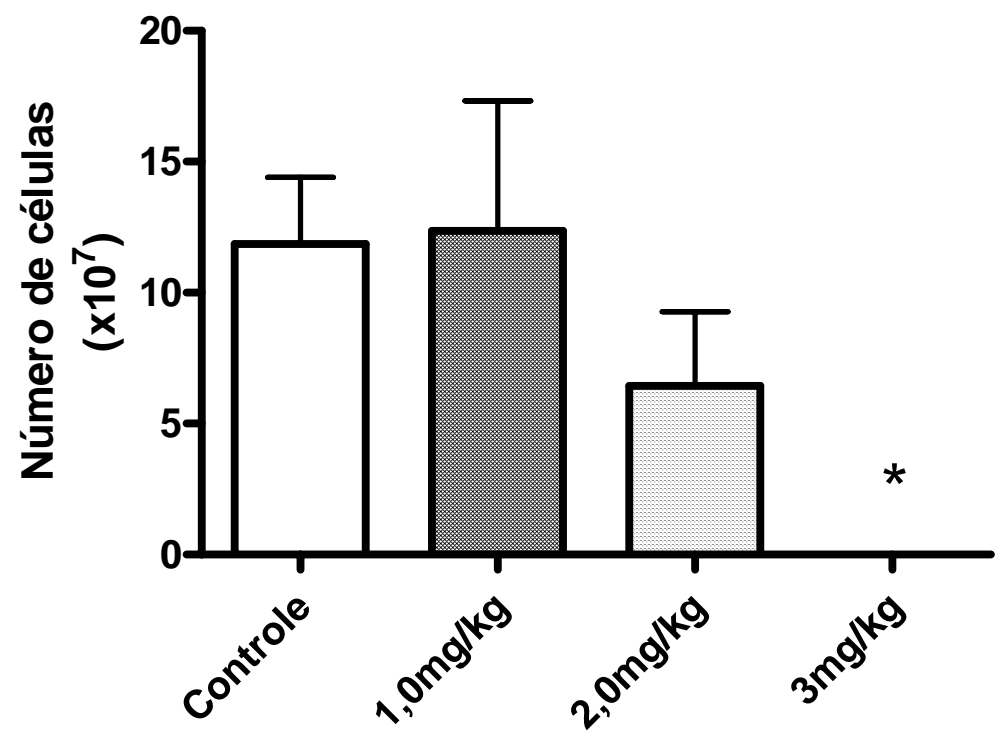

Figura 15: Número de células tumorais por $\mathrm{mL}$ de camundongos inoculados com tumor ascítico de Ehrlich e tratados com 1,0; 2,0 e 3,0mg/kg de cisplatina, nos dias 2, 4, 6, 8 e 10. São apresentadas as medias e os respectivos erros padrões ( $\mathrm{n}=7-9$ por grupo) (Kruskal Wallis - pós teste de Dunn's * $p<0,05$, quando comparado com o grupo controle) 


\section{Volume tumoral}

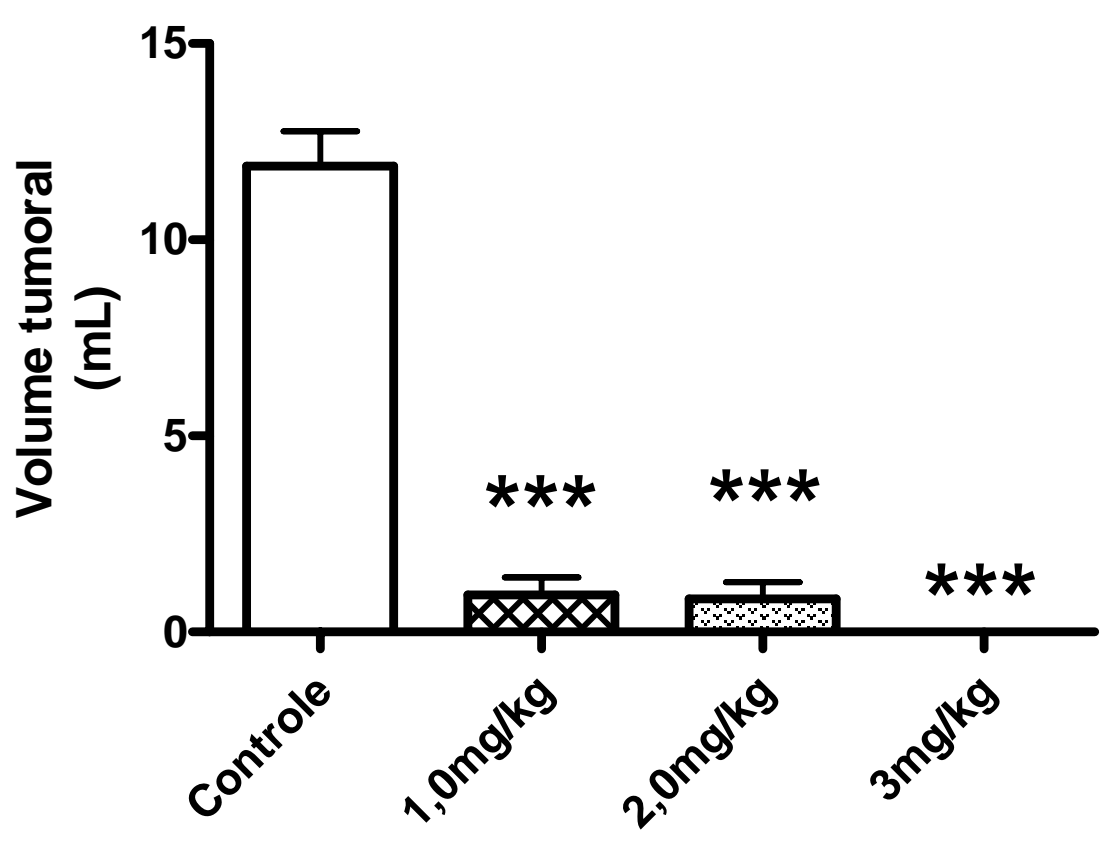

\section{Número total de células tumorais}

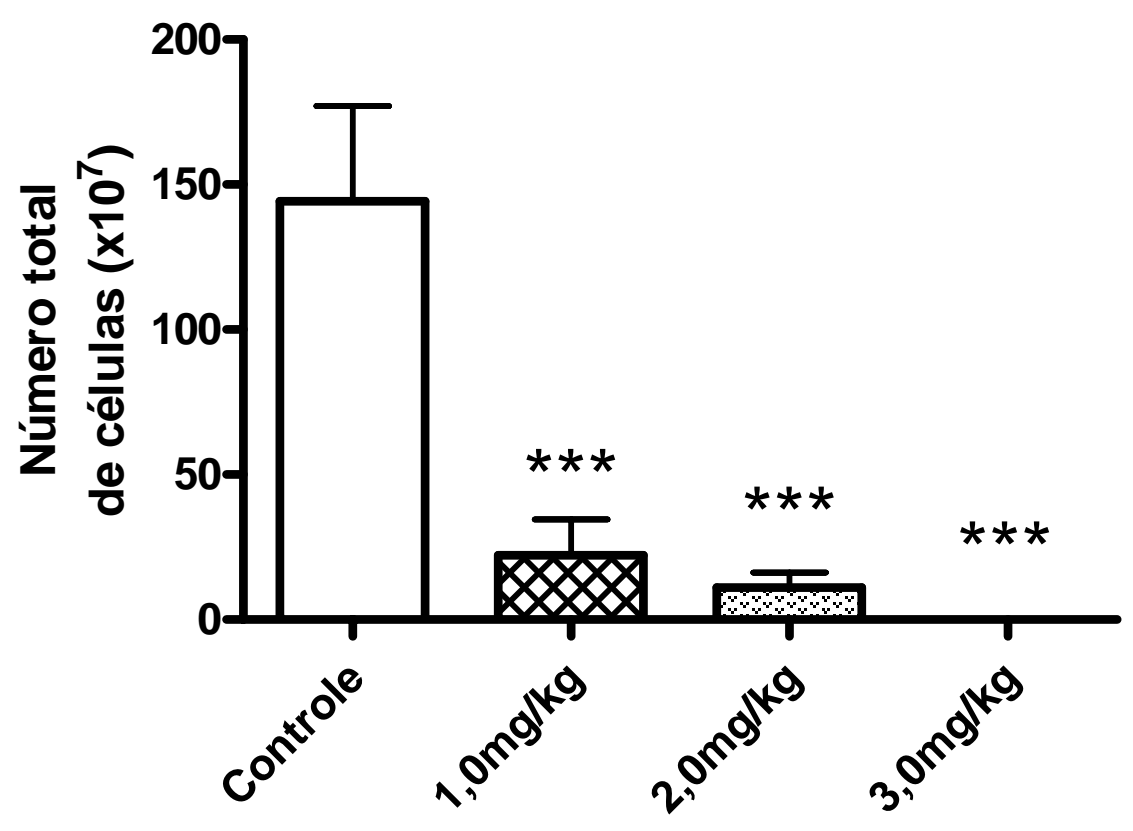

Figura 16: Volume e número total de células tumorais de camundongos inoculados com tumor ascítico de Ehrlich e tratados com 1,0; 2,0 e 3,0mg/kg de cisplatina, nos dias 2, 4, 6, 8 e 10. São apresentadas as medias e os respectivos erros padrões ( $n=7-9$ por grupo). (ANOVA pós teste de Dunnett's ${ }^{\star \star \star} p<0,001$, quando comparado com o grupo controle) 


\begin{tabular}{|c|c|}
\hline Grupos & Descrição dos achados histopatológicos de tecido hepático \\
\hline Controle & $\begin{array}{l}\text { Discreto infiltrado de células inflamatórias, de caráter } \\
\text { multifocal ( } 3 \text { focos por fragmento histológico); } \\
\text { Presença de células neoplásicas e de infiltrado inflamatório } \\
\text { em torno da cápsula hepática; } \\
\text { Presença de raros focos neoplásicos no parênquima } \\
\text { hepático. }\end{array}$ \\
\hline $\begin{array}{l}\text { 1,0mg/kg } \\
\text { cisplatina }\end{array}$ & $\begin{array}{l}\text { Número maior de focos de células inflamatórias (10-15 focos } \\
\text { por fragmento); } \\
\text { Necroses individuais de hepatócitos (presença de linfócitos, } \\
\text { neutrófilos e células de Kupfer); } \\
>\text { Discreta congestão; } \\
\text { Presença de figuras de mitose; } \\
>\text { Presença de células neoplásicas e de infiltrado inflamatório } \\
\text { em torno da cápsula hepática. }\end{array}$ \\
\hline $\begin{array}{l}2,0 \mathrm{mg} / \mathrm{kg} \\
\text { cisplatina }\end{array}$ & $\begin{array}{l}\text { Número maior de focos de células inflamatórias (10-15 focos } \\
\text { por fragmento); } \\
\text { Presença de figuras de mitose atípica; } \\
\text { Diminuição do número de células neoplásicas em torno da } \\
\text { cápsula hepática, redução do infiltrado inflamatório. }\end{array}$ \\
\hline $\begin{array}{l}3,0 \mathrm{mg} / \mathrm{kg} \\
\text { cisplatina }\end{array}$ & $\begin{array}{l}\text { Discreto infiltrado de células inflamatórias, de caráter } \\
\text { multifocal ( } 3 \text { focos por fragmento histológico); } \\
\text { Não foi possível notar a presença de células neoplásicas ao } \\
\text { redor da cápsula hepática, nem de infiltrado inflamatório. }\end{array}$ \\
\hline
\end{tabular}




\begin{tabular}{|c|c|}
\hline Grupos & Descrição dos achados histopatológicos de tecido renal \\
\hline Controle & $\begin{array}{l}\text { Presença de células neoplásicas associadas a infiltrado } \\
\text { inflamatório aderido a cápsula peri-renal; } \\
\text { Discreta congestão; } \\
\text { Preservação da arquitetura histológica e glomérulos livres de } \\
\text { processos patológicos. Tecido dentro do padrão da normalidade. }\end{array}$ \\
\hline $\begin{array}{l}1,0 \mathrm{mg} / \mathrm{kg} \\
\text { cisplatina }\end{array}$ & $\begin{array}{l}\text { Cápsula peri-renal com poucas células neoplásicas e reduzido } \\
\text { infiltrado inflamatório; } \\
>\text { Discreta congestão e presença de alguns focos hemorrágicos; } \\
\text { Diminuição da segmentação glomerular; e discreto quadro de } \\
\text { glomerulonefrite membranoproliferativa multifocal segmentar. }\end{array}$ \\
\hline $\begin{array}{l}2,0 \mathrm{mg} / \mathrm{kg} \\
\text { cisplatina }\end{array}$ & $\begin{array}{l}\text { Cápsula peri-renal com poucas células neoplásicas e reduzido } \\
\text { infiltrado inflamatório; } \\
>\text { Discreta congestão e presença de poucos focos hemorrágicos; } \\
>\text { Discreta nefrose; } \\
>\text { Diminuição da segmentação glomerular; e discreto quadro de } \\
\text { glomerulonefrite membranoproliferativa multifocal segmentar. }\end{array}$ \\
\hline $\begin{array}{l}3,0 \mathrm{mg} / \mathrm{kg} \\
\text { cisplatina }\end{array}$ & $\begin{aligned} & \text { Cápsula peri-renal sem células neoplásicas e apresentando } \\
& \text { reduzido infiltrado inflamatório; } \\
> & \text { Discreta congestão e presença de poucos focos hemorrágicos; } \\
> & \text { Aumento do quadro de nefrose; } \\
> & \text { Presença de cilindros hialinos, e proteinúria em túbulos } \\
& \text { proximais; } \\
> & \text { Células mesoteliais reativas; } \\
> & \text { Diminuição da segmentação glomerular; e discreto quadro de } \\
& \text { glomerulonefrite membranoproliferativa multifocal segmentar. }\end{aligned}$ \\
\hline
\end{tabular}

Quadro 5: Descrição histopatológica de tecido renal de camundongos inoculados com o tumor ascítico de Ehrlich, pertencentes ao grupo controle e aos grupos tratados com 1,0; 2,0 e $3,0 \mathrm{mg} / \mathrm{kg}$ de cisplatina, nos dias 2, 4, 6, 8 e 10 
4.4 Experimento 4: Administração de 0,25; 0,5 e 0,75mg/kg de cisplatina em camundongos C57BI/6 inoculados com o tumor ascítico de Ehrlich: avaliação de celularidade de medula óssea, volume tumoral e contagem total de células tumorais

A contagem total de células medulares de camundongos inoculados com o tumor ascítico de Ehrlich não mostrou diferenças estatísticas entre os grupos tratados ou não com a cisplatina (ANOVA, $F=0,9647 ; d f=3 / 30 ; p=0,4222$ ). A tabela 7 e a figura 17 ilustram esses dados.

Em relação ao número de células tumorais por $\mathrm{mL}$, não foi possível notar qualquer diferença significante entre os grupos (ANOVA, $F=0,3305 ; d f=3 / 25$; $p=0,2464-$ Tabela 8 e figura 18).

Porém, foi observada uma diminuição do volume tumoral dos animais dos grupos experimentais quando comparados àqueles do grupo controle (ANOVA $F=4.944 ; d f=3 / 23 ; p=0,0079$ - pós teste de Dunnett's - $p<0,05)$, conforme mostram a tabela 8 e a figura 19. Quanto ao número total de células tumorais, também se observou uma redução deste parâmetro nos animais de todos os grupos experimentais em relação àqueles do grupo controle (ANOVA, F=12,760; $\mathrm{df}=3 / 25 ; p<0,0001$ - pós teste de Dunnett's - $p<0,001)$, conforme mostram a tabela 8 e a figura 20.

Em relação ao hematócrito, observou-se redução deste parâmetro apenas nos animais no grupo tratado com $0,25 \mathrm{mg} / \mathrm{kg}$ de cisplatina em comparação aos animais do grupo controle (Kruskal-Wallis - KW=9,162; $\mathrm{p}=0,0272$ - pós teste de Dunn's - $p<0,05)$. A tabela 9 mostra e a figura 21 ilustra tais dados. 
Os quadros 6 e 7 apresentam as descrições histopatológicas dos tecidos hepático e renal de camundongos inoculados com o tumor ascítico de Ehrlich pertencentes ao grupo controle e aos grupos tratados com as diferentes doses de cisplatina. Assim, no fígado dos animais do grupo controle nota-se, em torno da cápsula hepática, a presença de células neoplásicas e de infiltrado inflamatório; observa-se também a presença de raros focos neoplásicos no parênquima do órgão. Nos animais dos grupos experimentais observa-se moderada redução da ocorrência destes achados na medida em que se aumenta a dose de cisplatina.

Nos rins dos animais do grupo controle, em torno da cápsula renal, observou-se a presença de células neoplásicas e de infiltrado inflamatório, porém foi mantida a arquitetura histológica do órgão e os glomérulos mostravam-se livres de processos patológicos, caracterizando um tecido dentro do padrão da normalidade. Nos animais dos grupos experimentais, na medida em que se aumentou a dose de cisplatina, observou-se moderada redução da ocorrência das células neoplásicas aderidas à cápsula renal, porém, notou-se um ligeiro aumento gradativo da presença de lesões renais, como, por exemplo, discreta congestão, focos hemorrágicos e nefrose. 
Tabela 7: Celularidade de medula óssea de camundongos C57BL/6 inoculados com tumor ascítico de Ehrlich e tratados com diferentes doses de cisplatina, nos dias 2, 4, 6, 8 e 10

\begin{tabular}{|ccccc|}
\hline & Controle & \multicolumn{3}{c|}{ Cisplatina } \\
\cline { 3 - 5 } & $(\mathbf{n}=7)$ & $\begin{array}{c}\mathbf{0 , 2 5} \mathbf{m g} / \mathbf{k g} \\
(\mathbf{n}=\mathbf{9})\end{array}$ & $\begin{array}{c}\mathbf{0 , 5} \mathbf{m g} / \mathbf{k g} \\
(\mathbf{n}=\mathbf{9})\end{array}$ & $\begin{array}{c}\mathbf{0 , 7 5} \mathbf{m g} / \mathbf{k g} \\
(\mathbf{n}=\mathbf{9})\end{array}$ \\
\hline Número total de células & 72,14 & 64,72 & 69,03 & 61,25 \\
da medula óssea $(\mathbf{1 0})$ & $\pm 6,76$ & $\pm 4,07$ & $\pm 2,56$ & $\pm 5,51$ \\
\hline
\end{tabular}

São apresentadas as medias e os respectivos erros padrões (ANOVA - $p<0,05$ quando comparado com o grupo controle).

\section{Contagem total das células da medula óssea}

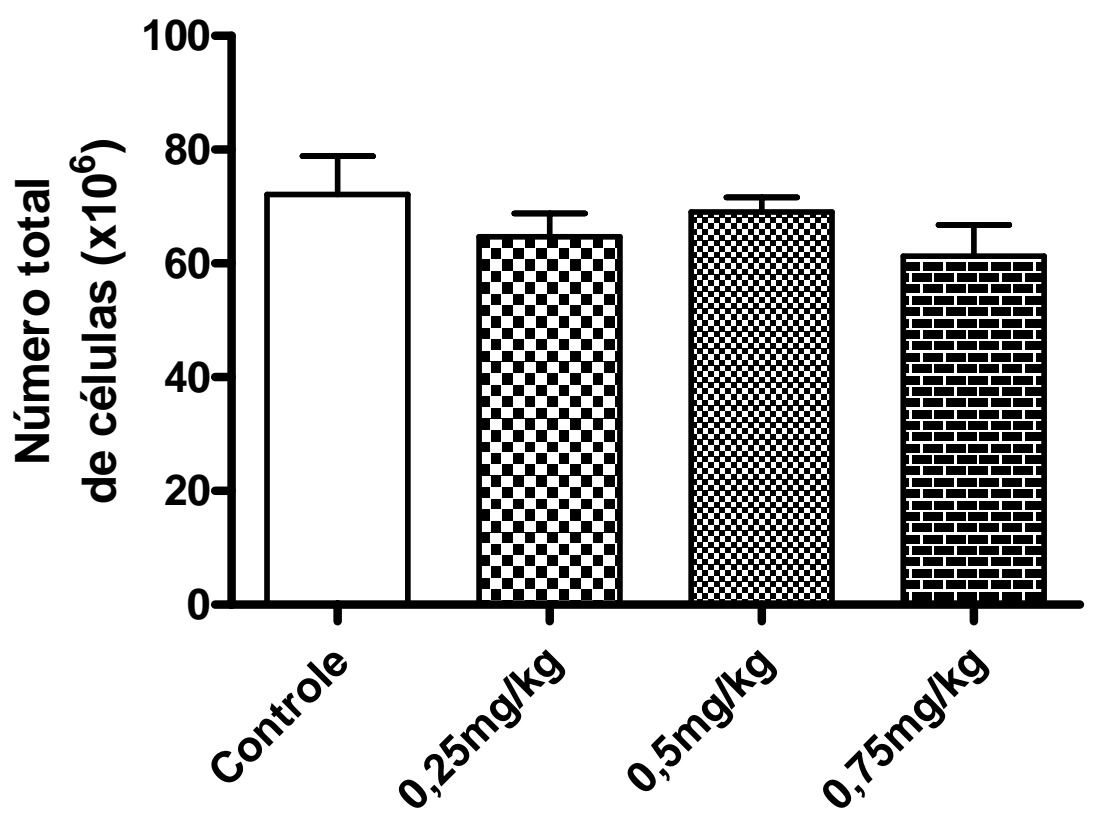

Figura 17: Celularidade de medula óssea de camundongos C57BL/6 inoculados com tumor ascítico de Ehrlich e tratados com diferentes doses de cisplatina, nos dias 2, 4, 6, 8 e 10. São apresentadas as medias e os respectivos erros padrões ( $n=7-9$ por grupo). (ANOVA $p<0,05$, quando comparado com o grupo controle) 
Tabela 8: Volume, número total de células tumorais e número de células tumorais por $\mathrm{mL}$ de camundongos C57BL/6 inoculados com tumor ascítico de Ehrlich e tratados com diferentes doses de cisplatina, nos dias $2,4,6,8$ e 10

\begin{tabular}{|c|c|c|c|c|}
\hline & \multirow{2}{*}{$\begin{array}{c}\text { Controle } \\
(n=6)\end{array}$} & \multicolumn{3}{|c|}{ Cisplatina } \\
\hline & & $\begin{array}{c}0,25 \mathrm{mg} / \mathrm{kg} \\
(\mathrm{n}=7)\end{array}$ & $\begin{array}{c}0,5 \mathrm{mg} / \mathrm{kg} \\
(\mathrm{n}=9)\end{array}$ & $\begin{array}{c}0,75 \mathrm{mg} / \mathrm{kg} \\
(\mathrm{n}=7)\end{array}$ \\
\hline $\begin{array}{c}\text { Número de } \\
\text { células } \\
\text { tumorais por } \\
\text { mL }\left(\times 10^{7}\right)\end{array}$ & $11,67 \pm 1,82$ & $10,00 \pm 1,13$ & $9,75 \pm 1,54$ & $11,75 \pm 2,69$ \\
\hline $\begin{array}{c}\text { Volume } \\
\text { tumoral }(\mathrm{mL})\end{array}$ & $14,78 \pm 0,74$ & $8,44 \pm 1,46^{\star}$ & $6,69 \pm 1,77^{\star \star}$ & $7,84 \pm 1,58^{\star}$ \\
\hline $\begin{array}{c}\text { Número total } \\
\text { de } \\
\text { células } \\
\text { tumorais } \\
\left(\times 10^{7}\right)\end{array}$ & $168,0 \pm 19,31$ & $77,41 \pm 12,73^{\star \star \star}$ & $50,62 \pm 13,37^{\star \star *}$ & $67,98 \pm 10,51^{* \star *}$ \\
\hline
\end{tabular}

São apresentadas as medias e os respectivos erros padrões (ANOVA pós teste de Dunnett's ${ }^{*} p<0,05 ;{ }^{* \star} p<0,01 ;{ }^{* \star} p<0,001$, quando comparado com o grupo controle).

\section{Número de células tumorais por $\mathrm{mL}$}

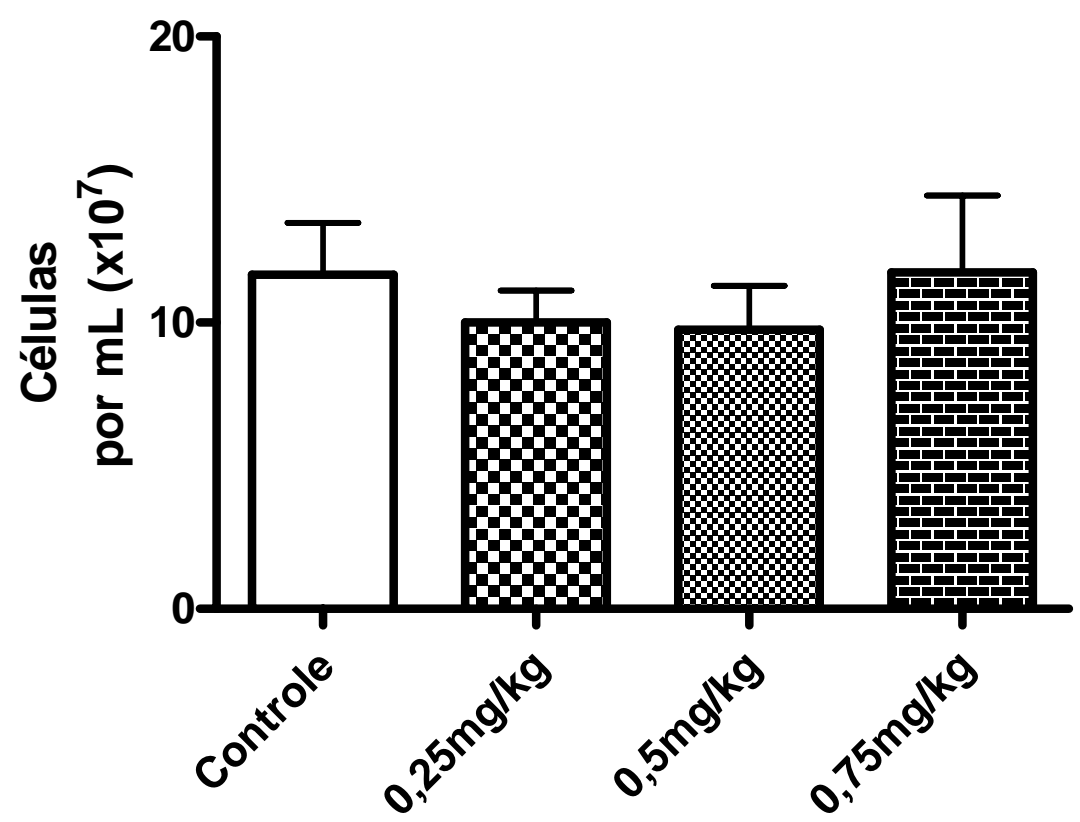

Figura 18: Número de células tumorais por $\mathrm{mL}$ de camundongos C57BL/6 inoculados com tumor ascítico de Ehrlich tratados com diferentes doses de cisplatina, nos dias 2, 4, 6, 8 e 10. São apresentadas as medias e os respectivos erros padrões ( $n=6-9$ por grupo). (ANOVA $p>0,05$, quando comparado com o grupo controle) 


\section{Volume tumoral}

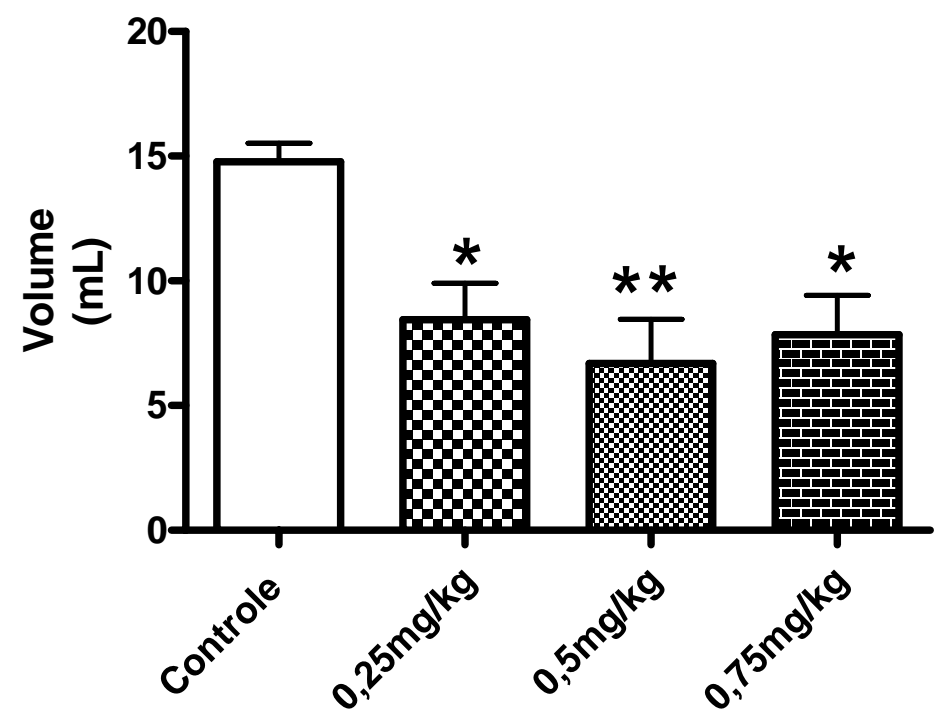

Figura 19: Volume tumoral de camundongos C57BL/6 inoculados com tumor ascítico de Ehrlich tratados com diferentes doses de cisplatina, nos dias 2, 4, 6, 8 e 10. São apresentadas as medias e os respectivos desvios padrões ( $n=6-9$ por grupo). (ANOVA - pós teste de Dunnett's - ${ }^{*} p<0,05 ;{ }^{*} p<0,01$, quando comparado com o grupo controle)

\section{Número total de células tumorais}

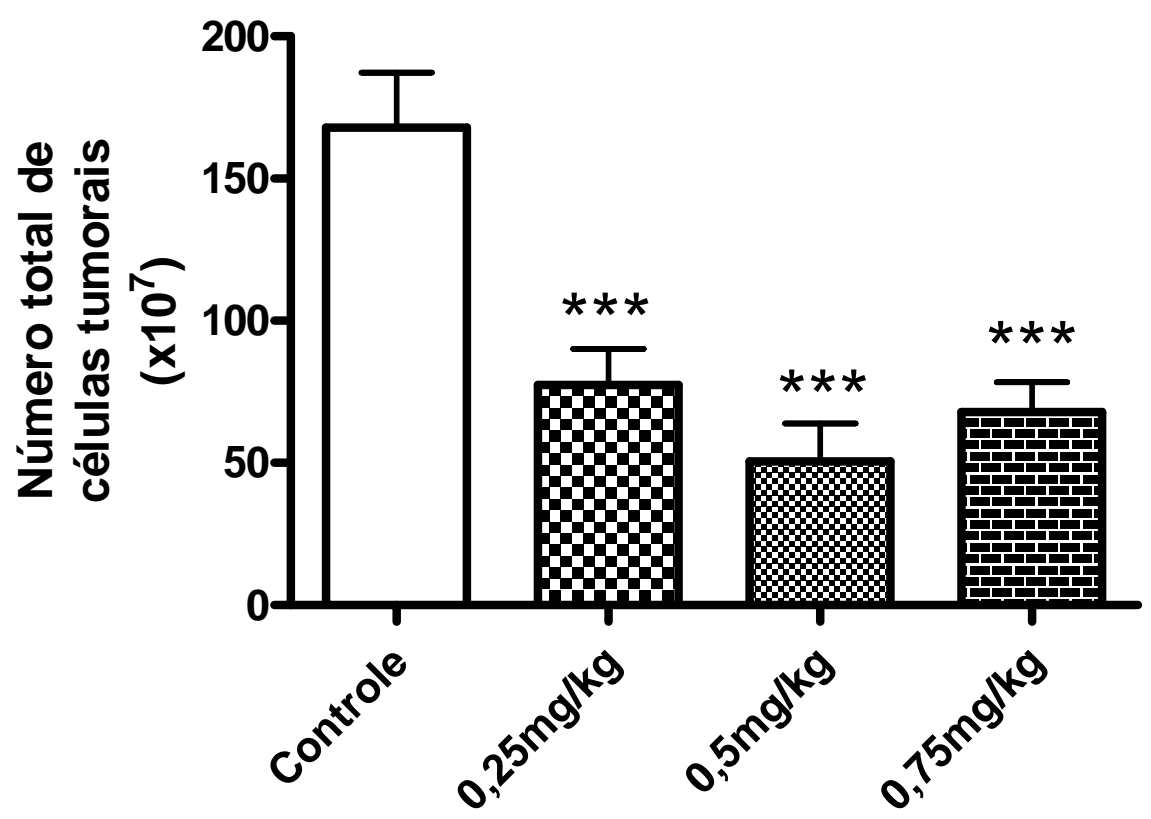

Figura 20: Número total de células tumorais de camundongos C57BL/6 inoculados com tumor ascítico de Ehrlich tratados com diferentes doses de cisplatina, nos dias 2, 4, 6, 8 e 10. São apresentadas as medias e os respectivos erros padrões ( $n=6-9$ por grupo). (ANOVA seguida do teste de comparações múltiplas de Dunnett's - ${ }^{*} p<0,01$, quando comparado com o grupo controle) 
Tabela 9: Valores de hematócrito de camundongos C57BL/6 inoculados com tumor ascítico de Ehrlich tratados com diferentes doses de cisplatina, nos dias experimentais 2, 4, 6, 8 e 10

\begin{tabular}{|c|c|c|c|c|}
\hline & \multirow{2}{*}{$\begin{array}{c}\text { Controle } \\
(n=7)\end{array}$} & \multicolumn{3}{|c|}{ Cisplatina } \\
\hline & & $\begin{array}{c}0,25 \mathrm{mg} / \mathrm{kg} \\
(\mathrm{n}=7)\end{array}$ & $\begin{array}{c}0,5 \mathrm{mg} / \mathrm{kg} \\
(\mathrm{n}=5)\end{array}$ & $\begin{array}{c}0,75 \mathrm{mg} / \mathrm{kg} \\
(\mathrm{n}=8)\end{array}$ \\
\hline $\begin{array}{c}\text { Hematócrito } \\
\text { (\%) }\end{array}$ & $48,14 \pm 1,49$ & $41,00 \pm 1,38 *$ & $42,40 \pm 1,60$ & $42,25 \pm 1,40$ \\
\hline
\end{tabular}

\section{Hematócrito}

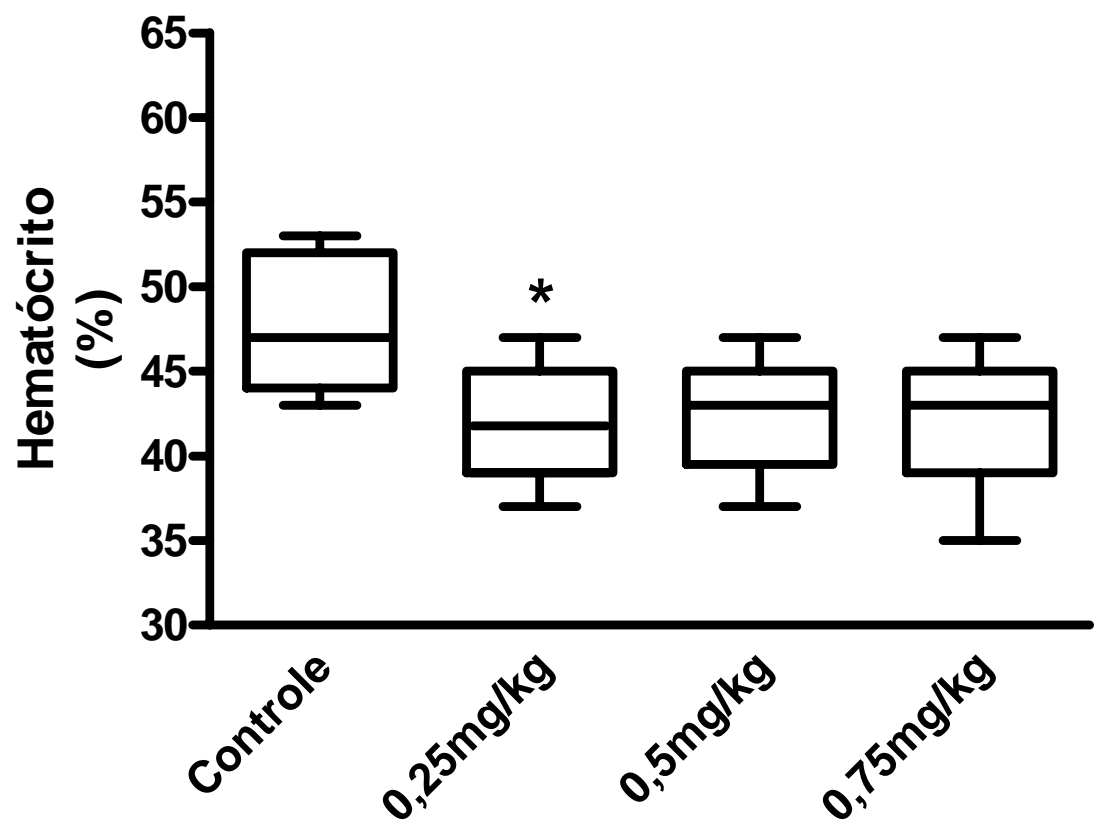

Figura 21: Valores de hematócrito de camundongos C57BL/6 inoculados com tumor ascítico de Ehrlich tratados com diferentes doses de cisplatina, nos dias 2, 4, 6, 8 e 10. São apresentadas as medianas, as médias (traços horizontais dentro das caixas) e os limites superiores e inferiores ( $n=5-6$ por grupo) (Kruskal-Wallis - pós teste de Dunn's - ${ }^{*} p<0,05$, quando comparado com o grupo controle) 


\begin{tabular}{|c|c|}
\hline Grupos & Descrição dos achados histopatológicos de tecido hepático \\
\hline Controle & $\begin{array}{l}\text { Raros infiltrados de células inflamatórias, de caráter } \\
\text { multifocal (2 focos por fragmento histológico); } \\
\text { Em torno da cápsula hepática nota-se a presença de células } \\
\text { neoplásicas e de infiltrado inflamatório; } \\
>\text { Presença de raros focos neoplásicos no parênquima } \\
\text { hepático. }\end{array}$ \\
\hline $\begin{array}{l}0,25 \mathrm{mg} / \mathrm{kg} \\
\text { cisplatina }\end{array}$ & $\begin{array}{l}>\text { Raros focos de células inflamatórias (2 focos por fragmento); } \\
\text { Discreta congestão; } \\
\text { Algumas figuras de mitose; } \\
\text { Presença de poucos focos neoplásicos no parênquima } \\
\text { hepático; } \\
>\text { Presença de células neoplásicas e de infiltrado } \\
\text { inflamatório.em torno da cápsula hepática. }\end{array}$ \\
\hline $\begin{array}{l}0,5 \mathrm{mg} / \mathrm{kg} \\
\text { cisplatina }\end{array}$ & $\begin{array}{l}\text { Poucos focos de células inflamatórias (3 focos por } \\
\text { fragmento); } \\
>\text { Discreta congestão; } \\
>\text { Presença de células neoplásicas na circulação; } \\
\text { D Diminuição do número de células neoplásicas em torno da } \\
\text { cápsula hepática e redução do infiltrado inflamatório. }\end{array}$ \\
\hline $\begin{array}{l}0,75 \mathrm{mg} / \mathrm{kg} \\
\text { cisplatina }\end{array}$ & $\begin{array}{l}\text { Discreto infiltrado de células inflamatórias, de caráter } \\
\text { multifocal ( } 3 \text { focos por fragmento histológico); } \\
\text { Diminuição da presença de células neoplásicas ao redor da } \\
\text { cápsula hepática e de pouco infiltrado inflamatório. }\end{array}$ \\
\hline
\end{tabular}

Quadro 6: Descrição histopatológica de tecido hepático de camundongos C57BL/6 inoculados com o tumor ascítico de Ehrlich, pertencentes ao grupo controle e aos grupos tratados com 0,25; 0,5 e $0,75 \mathrm{mg} / \mathrm{kg}$ de cisplatina, nos dias 2, 4, 6, 8 e 10 


\begin{tabular}{|c|c|}
\hline Grupos & Descrição dos achados histopatológicos em tecido renal \\
\hline Controle & $\begin{array}{l}\text { Presença de células neoplásicas associadas a infiltrado } \\
\text { inflamatório aderido a cápsula peri-renal; } \\
\text { Discreta congestão; } \\
\text { Preservação da arquitetura histológica e glomérulos livres } \\
\text { de processos patológicos. Tecido dentro do padrão da } \\
\text { normalidade. }\end{array}$ \\
\hline $\begin{array}{l}0,25 \mathrm{mg} / \mathrm{kg} \\
\text { cisplatina }\end{array}$ & $\begin{aligned} & \text { Cápsula peri-renal com células neoplásicas e infiltrado } \\
& \text { inflamatório; } \\
& \text { Discreta congestão e presença de alguns focos } \\
& \text { hemorrágicos; } \\
& \text { Pequena diminuição na segmentação glomerular; e quadro } \\
& \text { de glomerulonefrite membranoproliferativa multifocal } \\
& \text { segmentar muito discreto. }\end{aligned}$ \\
\hline $\begin{array}{l}0,5 \mathrm{mg} / \mathrm{kg} \\
\text { cisplatina }\end{array}$ & $\begin{array}{l}\text { C Cápsula peri-renal com poucas células neoplásicas e } \\
\text { reduzido infiltrado inflamatório; } \\
>\text { Discreta congestão e presença de poucos focos } \\
\text { hemorrágicos; } \\
\text { D Discreta nefrose; } \\
\text { D Presença de cilindros hialinos em túbulos proximais. }\end{array}$ \\
\hline $\begin{array}{l}0,75 \mathrm{mg} / \mathrm{kg} \\
\text { cisplatina }\end{array}$ & $\begin{array}{l}\text { Cápsula peri-renal sem células neoplásicas e apresentando } \\
\text { reduzido infiltrado inflamatório; } \\
\text { Discreta congestão e presença de poucos focos } \\
\text { hemorrágicos; } \\
>\text { Aumento do quadro de nefrose. }\end{array}$ \\
\hline
\end{tabular}

Quadro 7: Descrição histopatológica de tecido renal de camundongos C57BL/6 inoculados com o tumor ascítico de Ehrlich, pertencentes ao grupo controle e aos grupos tratados com 0,25; 0,5 e $0,75 \mathrm{mg} / \mathrm{kg}$ de cisplatina, nos dias $2,4,6,8$ e 10 
4.5 Experimento 5: Avaliação da sobrevida de camundongos C57BI/6, inoculados com tumor ascítico de Ehrlich, tratados com suainsonina ou RAF (resíduo aquoso final) da I. carnea administrando, concomitantemente ou não, a dose de $0,25 \mathrm{mg} / \mathrm{kg}$ de cisplatina

A figura 22 ilustra, em conjunto, as curvas de sobrevida dos animais expostos aos diferentes tratamentos (Cis; SW; RAF; CisRAF; CisSW e Controle), como descrito no item 4.6. O teste de Logrank mostrou diferenças significantes entre os grupos, sendo detectado um aumento da sobrevida dos animais do grupo CisSW, isto é, tratados com cisplatina e suainsonina $\left(Q u i^{2}=20,240\right.$ e $\mathrm{p}=0,0011)$

As figuras $23,24,25,26$ e 27 apresentam cada uma das curvas de sobrevida dos animais dos grupos experimentais comparadas com a curva do grupo controle. A média de sobrevida dos animais do grupo controle foi de 12,5 dias. Não foram notadas diferenças estatísticas entre os animais tratados com cisplatina (Cis - Figura 25), suainsonina (SW - Figura 24), o resíduo aquoso final da I. carnea (RAF - Figura 23) ou cisplatina mais RAF da l. carnea (CisRAF Figura 26) quando comparados àqueles do grupo controle. Vale ressaltar que os animais tratados com cisplatina apresentaram tendência de aumento de sobrevida $(p=0,0573)$, por exemplo, considerando o $14^{\circ}$ dia do experimento, em que todos os animais do grupo controle haviam morrido, o grupo tratado com cisplatina apresentava $28,57 \%$ de indivíduos vivos.

No mesmo sentido, comparando-se a curva de sobrevida dos animais do grupo tratado com cisplatina e RAF (CisRAF) com a curva do grupo controle, 
observou-se também tendência de aumento na sobrevida destes animais $(p=0,0595)$. Para exemplificar esta tendência, no $14^{\circ}$ dia do experimento, em que todos os animais do grupo controle haviam morrido, o grupo CisRAF apresentava $37,5 \%$ de indivíduos vivos.

A figura 27 mostra a curva de sobrevida do grupo tratado com cisplatina e suainsonina (CisSW) e a curva do grupo controle. A análise estatística mostrou aumento significante na sobrevida dos animais do grupo CisSW em relação àqueles do grupo controle (teste de Logrank - Qui ${ }^{2}=9,383 ; p=0,0022$ ). Para exemplificar esse aumento, no $14^{\circ}$ dia experimental, em que todos os animais do grupo controle haviam morrido, o grupo CisSW apresentava 71,5\% de indivíduos vivos.

A análise estatística entre os grupos Cis (tratados com cisplatina) e o grupo tratado com a combinação de cisplatina e o princípio ativo da I. carnea, a suainsonina (grupo CisSW), apresentou diferenças significativas. O grupo CisSW apresentou um aumento significante na curva de sobrevida em relação ao grupo Cis (teste de Logrank - Qui ${ }^{2}=4,752 ; \mathrm{p}=0,029$ ). Estes dados estão expostos na figura 28. 


\section{Curva de Sobrevida}

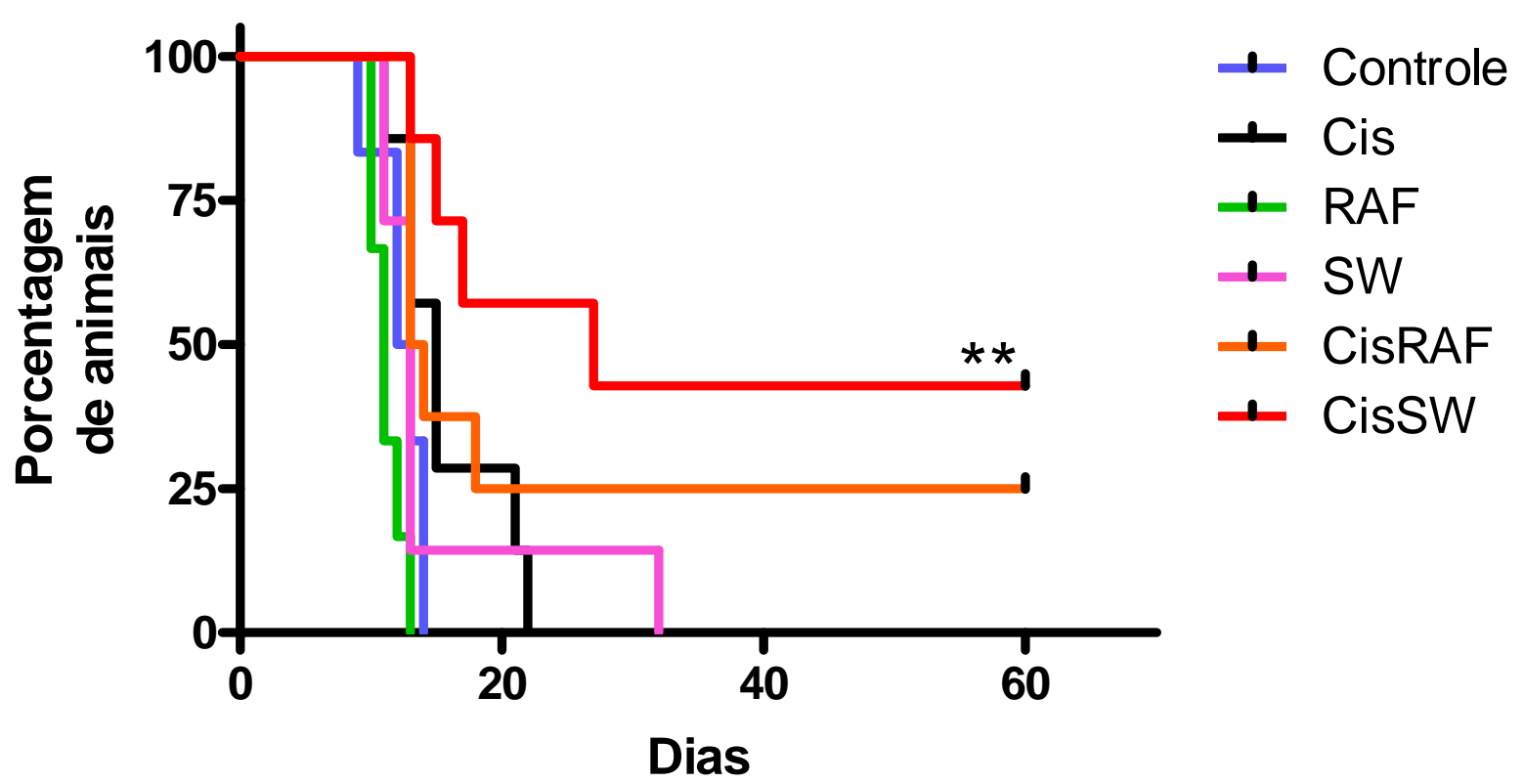

Figura 22: Curvas de sobrevida de camundongos C57BL/6 inoculados com tumor ascítico de Ehrlich e submetidos a diferentes tratamentos: $\mathrm{Co}=$ controle; $\mathrm{Cis}=$ tratado com cisplatina; $\mathrm{CisSW}$ $=$ tratado com cisplatina e suainsonina; $\mathrm{SW}=$ tratado com suainsonina; CisRAF = tratado com cisplatina e fração aquosa de $I$. carnea; RAF = tratado com fração aquosa de $I$. carnea. (Logrank test; ${ }^{\star \star}{ }^{\star}<0.01$, quando comparado com o grupo controle) 


\section{Curva de sobrevida}

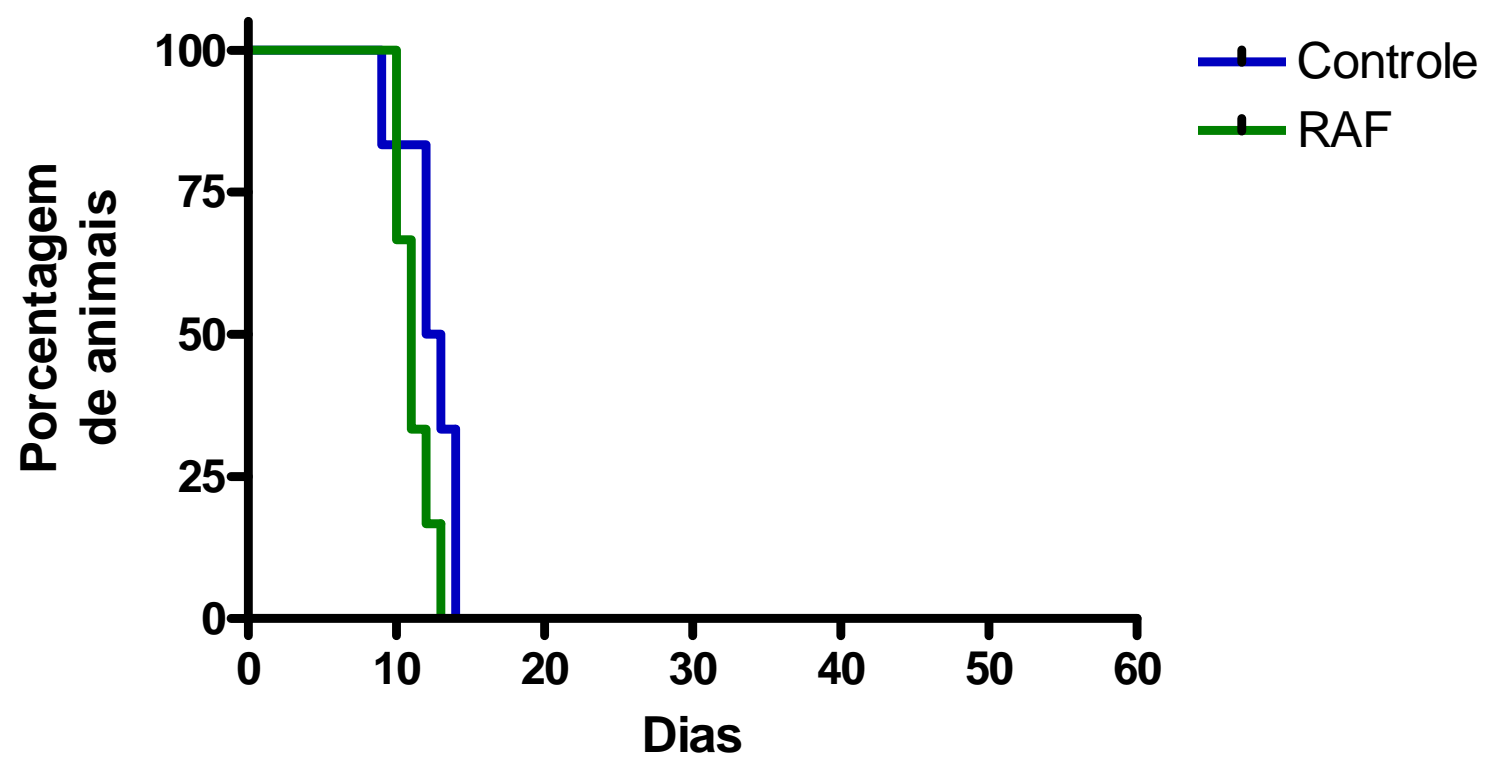

Figura 23: Curva de sobrevida de camundongos C57BL/6 inoculados com tumor ascítico de Ehrlich e submetidos a diferentes tratamentos: $\mathrm{Co}=$ controle e RAF $=$ tratado com resíduo aquoso final da I. carnea. (Logrank test; $p>0,05$ )

\section{Curva de sobrevida}

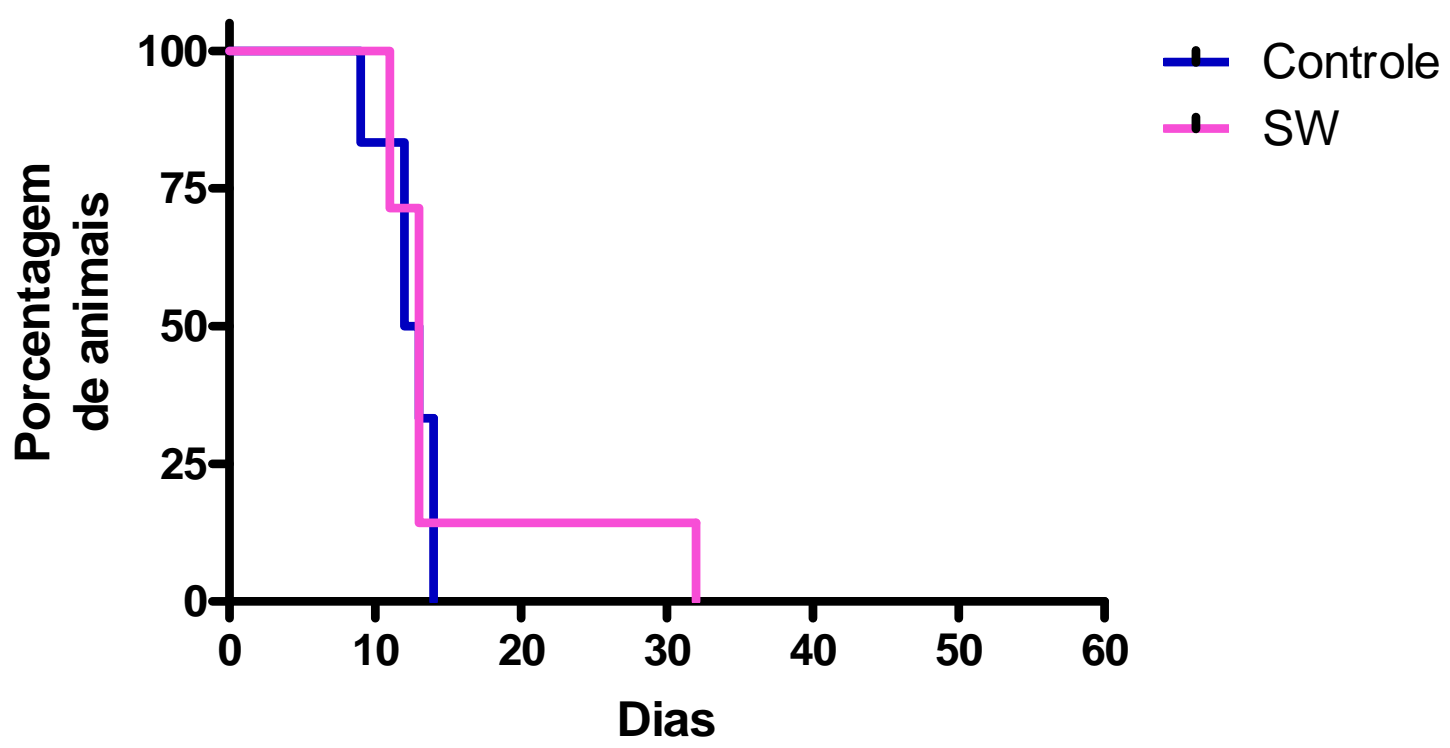

Figura 24: Curva de sobrevida de camundongos C57BL/6 inoculados com tumor ascítico de Ehrlich e submetidos a diferentes tratamentos: $\mathrm{Co}=$ controle e $\mathrm{SW}=$ tratado com suainsonina. (Logrank test; $p>0,05$ ) 


\section{Curva de sobrevida}

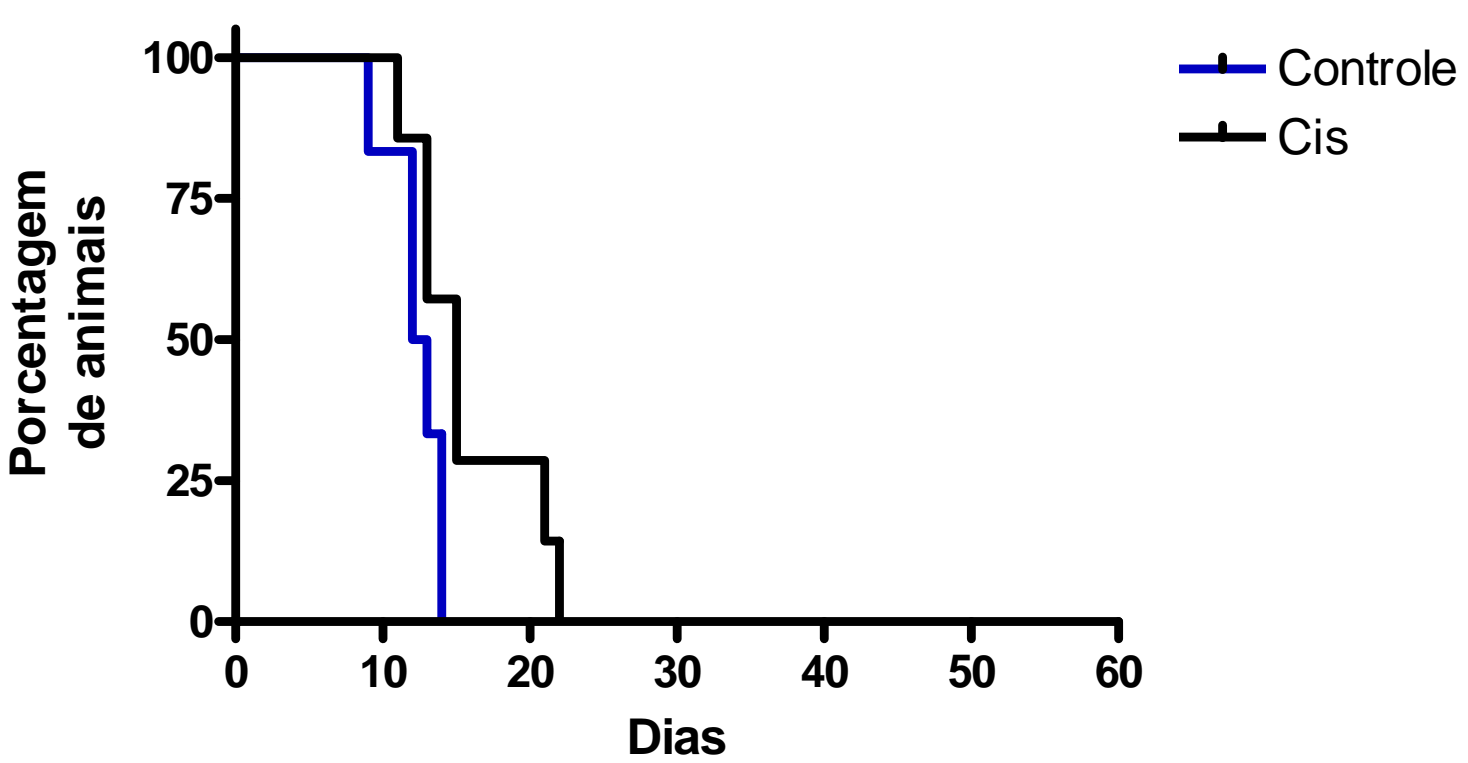

Figura 25: Curva de sobrevida de camundongos C57BL/6 inoculados com tumor ascítico de Ehrlich e submetidos a diferentes tratamentos: $\mathrm{Co}=$ controle e $\mathrm{Cis}=$ tratado com cisplatina na dose de $0,25 \mathrm{mg} / \mathrm{kg}$ (Logrank test; $\mathrm{p}=0,0573$ quando comparado com o grupo controle)

\section{Curva de sobrevida}

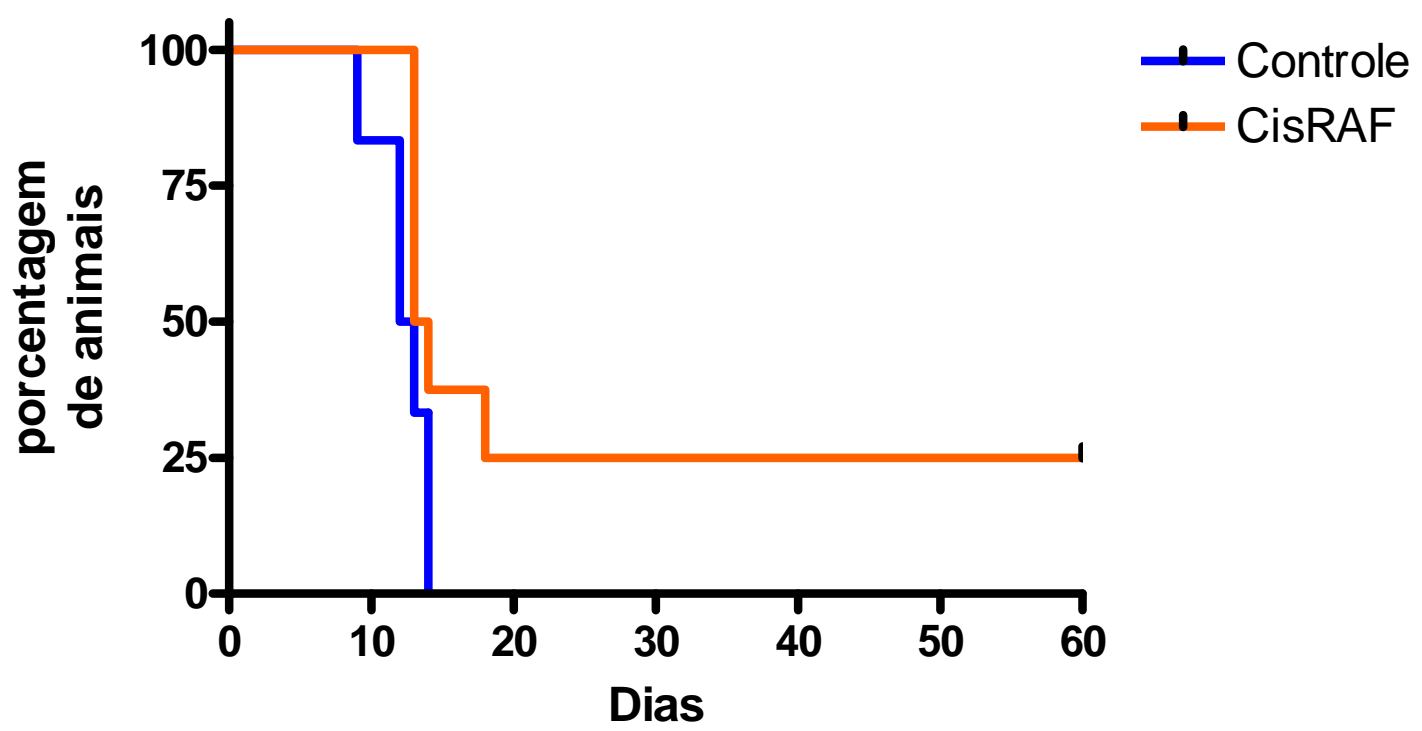

Figura 26: Curva de sobrevida de camundongos C57BL/6 inoculados com tumor ascítico de Ehrlich e submetidos a diferentes tratamentos: $\mathrm{Co}=$ controle e CisRAF $=$ tratado com cisplatina $\mathrm{e}$ com RAF da I. carnea (Logrank test; $p=0,0595$, quando comparado com o grupo controle) 


\section{Curva de sobrevida}

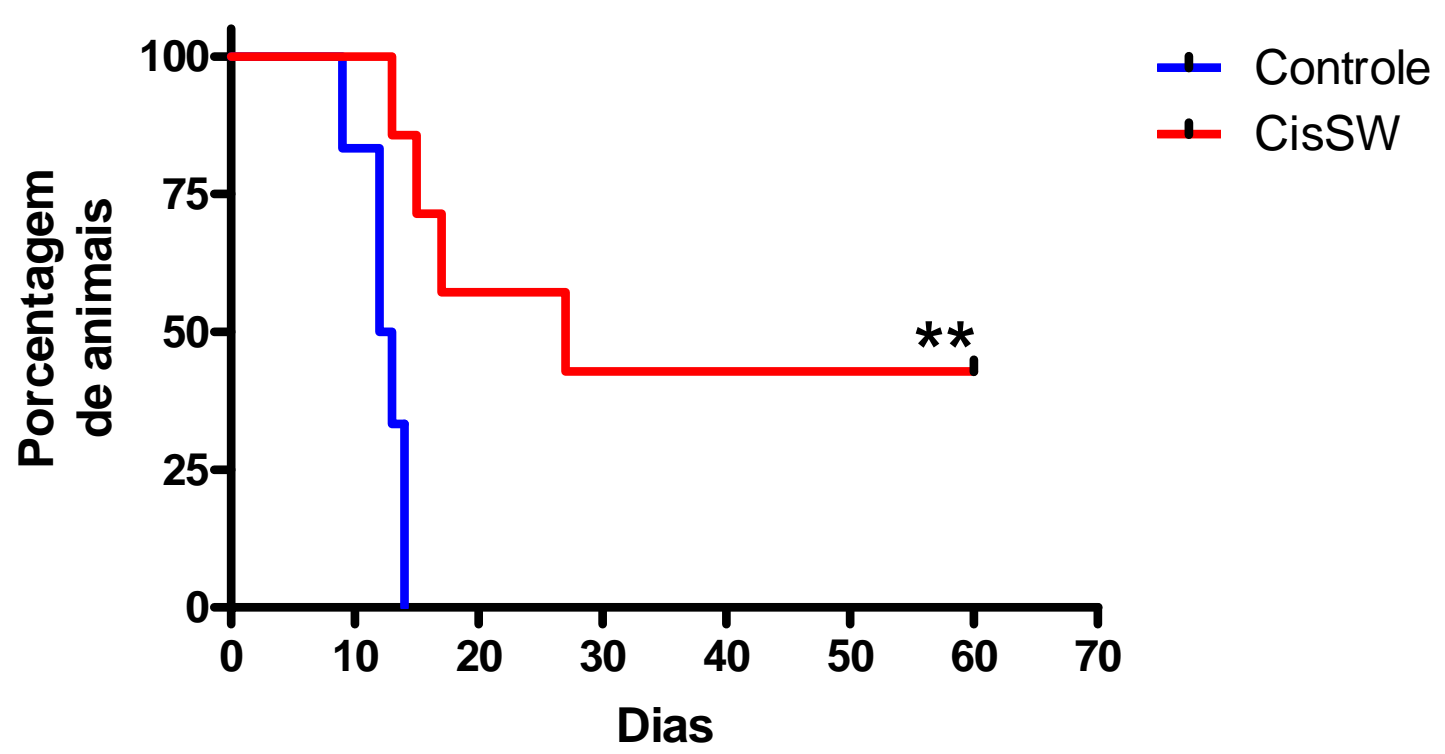

Figura 27: Curva de sobrevida de camundongos C57BL/6 inoculados com tumor ascítico de Ehrlich e submetidos a diferentes tratamentos: $\mathrm{Co}=$ controle e CisSW $=$ tratado com cisplatina e suainsonina (Logrank test; ${ }^{* \star} p<0,01$, quando comparado com o grupo controle)

\section{Curva de sobrevida}

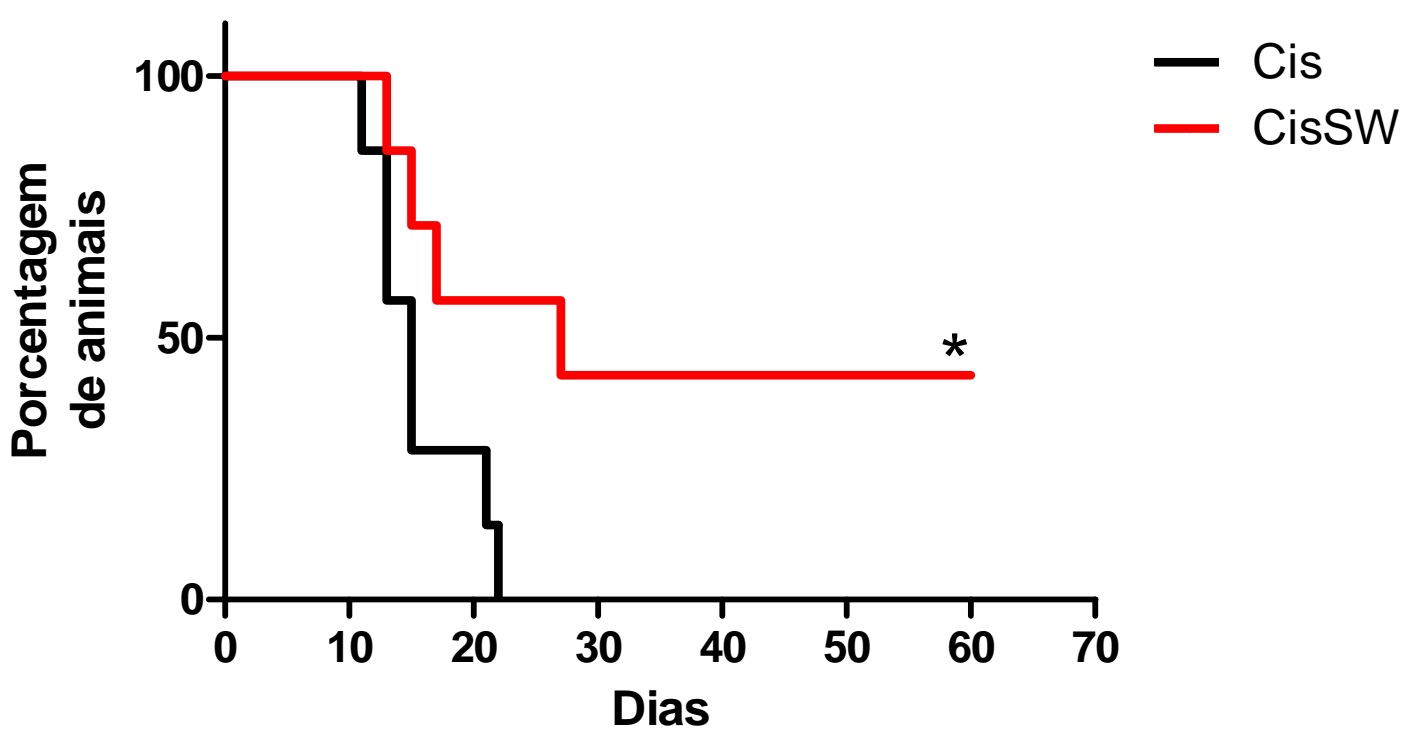

Figura 28: Curva de sobrevida de camundongos C57BL/6 inoculados com tumor ascítico de Ehrlich e submetidos a diferentes tratamentos: $\mathrm{Cis}=$ tratados com cisplatina e CisSW $=$ tratado com cisplatina e suainsonina (Logrank test; ${ }^{\star} p<0,05$, quando comparado ao grupo Cis) 
4.6 Experimento 6: Avaliação do crescimento tumoral de camundongos C57BI/6, inoculados com tumor ascítico de Ehrlich, tratados com suainsonina ou RAF (resíduo aquoso final) da l. carnea administrando, concomitantemente ou não, a dose de $0,25 \mathrm{mg} / \mathrm{kg}$ de cisplatina

\subsubsection{Crescimento tumoral (volume e celularidade):}

Após a retirada do tumor ascítico de Ehrlich dos animais, foi mensurado o volume tumoral obtido, sendo observado que apenas os animais dos grupos Cis e CisSW apresentaram uma redução significativa do volume tumoral quando comparados aos camundongos do grupo controle (ANOVA - F=9,106; $d f=5 / 53$; $p=0,0567$ - pós teste de Dunnett's $-p<0,05)$. Vale ressaltar que a redução do volume tumoral foi maior nos animais pertencentes ao grupo CisSW do que àquela dos camundongos do grupo Cis (tabela 10 e figura 29).

Em relação à celulariedade tumoral, foi avaliada tanto a quantidade de células tumorais $/ \mathrm{mL}$ da amostra, como a celularidade tumoral total. Na contagem de células tumorais/mL de cada amostra, foi possível observar redução significante deste parâmetro apenas nos animais do grupo Cis, quando comparados àqueles do grupo controle (Kruskal-Wallis - KW=14,45 $p<0,05$ - pós teste de Dunn's - $p<0,05)$ - Tabela 10 e figura 30. Observou-se também uma tendência em reduzir o número de células tumorais $/ \mathrm{mL}$ nos camundongos do grupo CisRAF em relação àqueles do grupo controle.

Em relação à celularidade tumoral total, observou-se diminuição do número total de células tumorais em animais dos grupos Cis $(p<0,01)$ e CisSW $(p<0,001)$, quando comparados aos animais pertencentes ao grupo controle 
(Kruskal-Wallis - KW=30,00; $\mathrm{p}<0,0001$ - pós teste de Dunn's - $\mathrm{p}<0,05)$ - Tabela 10 e figura 31. Vale destacar que os animais do grupo experimental CisRAF apresentaram tendência de diminuição deste parâmetro quando comparados aos animais do grupo controle.

A avaliação do número total de células viáveis, presentes no líquido tumoral ascítico dos camundongos, mostrou redução no número destas células em todos os animais tratados com cisplatina (isto é, Cis, CisSW e CisRAF), quando comparado àqueles do grupo controle (ANOVA - $F=14,37 \mathrm{df}=5 / 53$; $p<0,0001$ - pós teste de Dunnett's - $p<0,05)$ - Tabela 10 e figura 32.

A tabela 11 e a figura 33 ilustra a relação entre as o número total de células inviáveis e viáveis nos grupos controle, Cis e CisSW. Vale ressaltar que o menor número de células tumorais viáveis (vivas) foi encontrado no grupo CisSW, seguido do grupo Cis, como pode ser observado.

A tabela 11 e a figura 34 apresentam a porcentagem de células tumorais inviáveis nos grupos Co, Cis e CisSW. Apenas o grupo Cis apresentou redução significativa na porcentagem de células tumorais inviáveis quando comparado aos animais do grupo controle (Kruskal-Wallis - KW=7.406; $\mathrm{p}=0,0247$ - pós teste de Dunn's - $\mathrm{p}<0,05)$. As médias de células inviáveis no grupo Cis foi de 7,11\%; os camundongos do grupo controle apresentaram uma média de 15,88\% de células tumorais inviáveis, enquanto os animais tratados simultaneamente com cisplatina e suainsonina apresentaram uma média de 11,13\% células inviáveis. 
Tabela 10: Volume tumoral, número de células tumorais por $\mathrm{mL}$, número total de células tumorais e número total de células tumorais viáveis de camundongos C57BL/6 inoculados com tumor ascítico de Ehrlich e submetidos a diferentes tratamentos: Co = controle; Cis = tratado com cisplatina; CisSW = tratado com cisplatina e suainsonina; SW = tratado com suainsonina; CisRAF = tratado com cisplatina e fração aquosa de $I$. carnea; RAF = tratado com fração aquosa de l. carnea

\begin{tabular}{|c|c|c|c|c|c|c|}
\hline 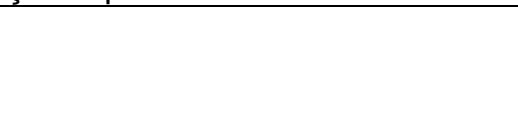 & $\begin{array}{c}\text { Co } \\
(n=10)\end{array}$ & $\begin{array}{c}\text { Cis } \\
(n=11)\end{array}$ & $\begin{array}{l}\text { CisSW } \\
(n=8)\end{array}$ & $\begin{array}{c}\text { Sw } \\
(n=10)\end{array}$ & $\begin{array}{l}\text { CisRAF } \\
(n=10)\end{array}$ & $\begin{array}{c}\text { RAF } \\
(n=10)\end{array}$ \\
\hline Volume & $14,21 \pm$ & $7,70 \pm$ & & & $10,57 \pm$ & $13,73 \pm$ \\
\hline Tumoral (mL) & 0,70 & $1,38 * * *$ & $1,85^{\star * *}$ & 0,66 & 0,99 & 1,11 \\
\hline $\begin{array}{c}\text { Número de células } \\
\text { tumorais por } \mathrm{mL}\left(\times 10^{7}\right)\end{array}$ & $\begin{array}{c}14,82 \pm \\
1,92\end{array}$ & $\begin{array}{c}8,13 \pm \\
0,70^{\#}\end{array}$ & $\begin{array}{c}15,09 \pm \\
4,56\end{array}$ & $\begin{array}{c}13,55 \pm \\
2,00\end{array}$ & $\begin{array}{c}8,63 \pm \\
1,02\end{array}$ & $\begin{array}{c}13,03 \pm \\
2,19\end{array}$ \\
\hline $\begin{array}{l}\text { Número total de células } \\
\text { tumorais }\left(\times 10^{8}\right)\end{array}$ & $\begin{array}{c}17,29 \pm \\
2,16\end{array}$ & $\begin{array}{l}5,86 \pm \\
1,11^{\# \#}\end{array}$ & $\begin{array}{c}3,50 \pm \\
0,77^{\# \# \#}\end{array}$ & $\begin{array}{c}15,98 \pm \\
1,35\end{array}$ & $\begin{array}{c}9,13 \pm \\
1,25\end{array}$ & $\begin{array}{c}13,43 \pm \\
2,42\end{array}$ \\
\hline $\begin{array}{l}\text { Número total de células } \\
\text { tumorais viáveis }\left(\times 10^{7}\right)\end{array}$ & $\begin{array}{c}167,7 \pm \\
16,20\end{array}$ & $\begin{array}{l}52,73 \pm \\
10,21^{* * *}\end{array}$ & $\begin{array}{l}27,53 \pm \\
7,23^{* * *}\end{array}$ & $\begin{array}{c}120,9 \pm \\
14,58\end{array}$ & $\begin{array}{l}89,27 \pm \\
15,00 * * *\end{array}$ & $\begin{array}{c}126,8 \pm \\
12,83\end{array}$ \\
\hline
\end{tabular}




\section{Volume tumoral}

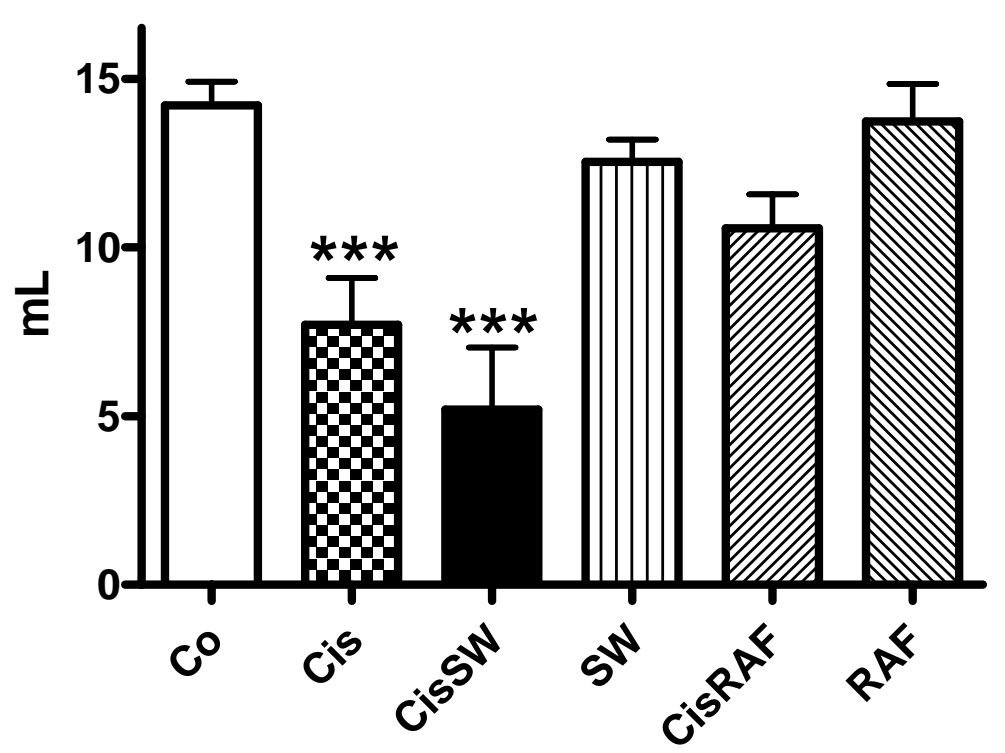

Figura 29: Volume tumoral de camundongos C57BL/6 inoculados com tumor ascítico de Ehrlich e submetidos a diferentes tratamentos: $\mathrm{Co}=$ controle; $\mathrm{Cis}=$ tratado com cisplatina; $\mathrm{CisSW}=$ tratado com cisplatina e suainsonina; SW = tratado com suainsonina; CisRAF = tratado com cisplatina e fração aquosa de $I$. carnea; RAF = tratado com fração aquosa de $I$. carnea. São apresentadas as medias e os respectivos erros padrões ( $n=11-12$ por grupo). ANOVA - pós teste de Dunnett's - *** $<<0,001$, quando comparado com o grupo controle

\section{Número de células tumorais por $\mathrm{mL}$}

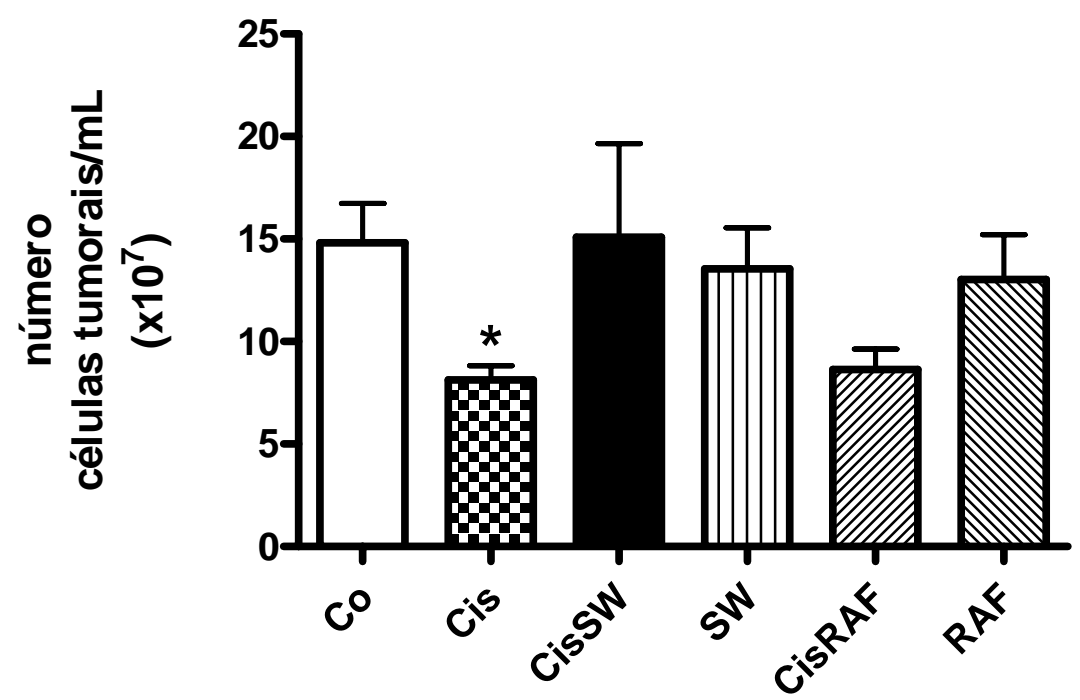

Figura 30: Número de células tumorais por $\mathrm{mL}$ de amostras provenientes de camundongos C57BL/6 inoculados com tumor ascítico de Ehrlich e submetidos a diferentes tratamentos: Co = controle; Cis = tratado com cisplatina; $\mathrm{CisSW}=$ tratado com cisplatina e suainsonina; $\mathrm{SW}=$ tratado com suainsonina; CisRAF = tratado com cisplatina e fração aquosa de I. carnea; RAF = tratado com fração aquosa de $I$. carnea. São apresentadas as médias e os respectivos erros padrões ( $\mathrm{n}=11-12$ por grupo). (Kruskal-Wallis - pós teste de Dunn's ${ }^{*} \mathrm{p}<0,05$, quando comparado com o grupo controle) 
Número total de células tumorais de Ehrlich

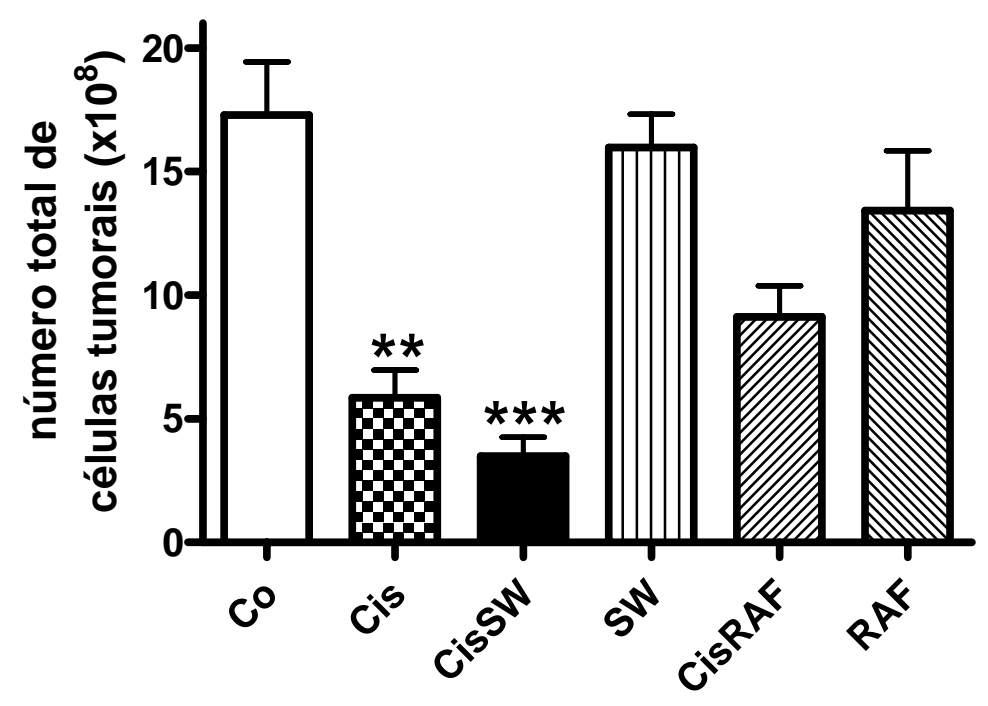

Figura 31: Número total de células tumorais de camundongos C57BL/6 inoculados com tumor ascítico de Ehrlich e submetidos a diferentes tratamentos: $\mathrm{Co}=$ controle; $\mathrm{Cis}=$ tratado com cisplatina; CisSW = tratado com cisplatina e suainsonina; $\mathrm{SW}=$ tratado com suainsonina; CisRAF = tratado com cisplatina e fração aquosa de $I$. carnea; RAF = tratado com fração aquosa de $I$. carnea. São apresentadas as medias e os respectivos erros padrões ( $n=11-12$ por grupo). (Kruskal-Wallis - pós teste de Dunn's - ** $p<0,01 ;{ }^{* \star \star} p<0,001$, quando comparado com o grupo controle)

\section{Número total de células viáveis}

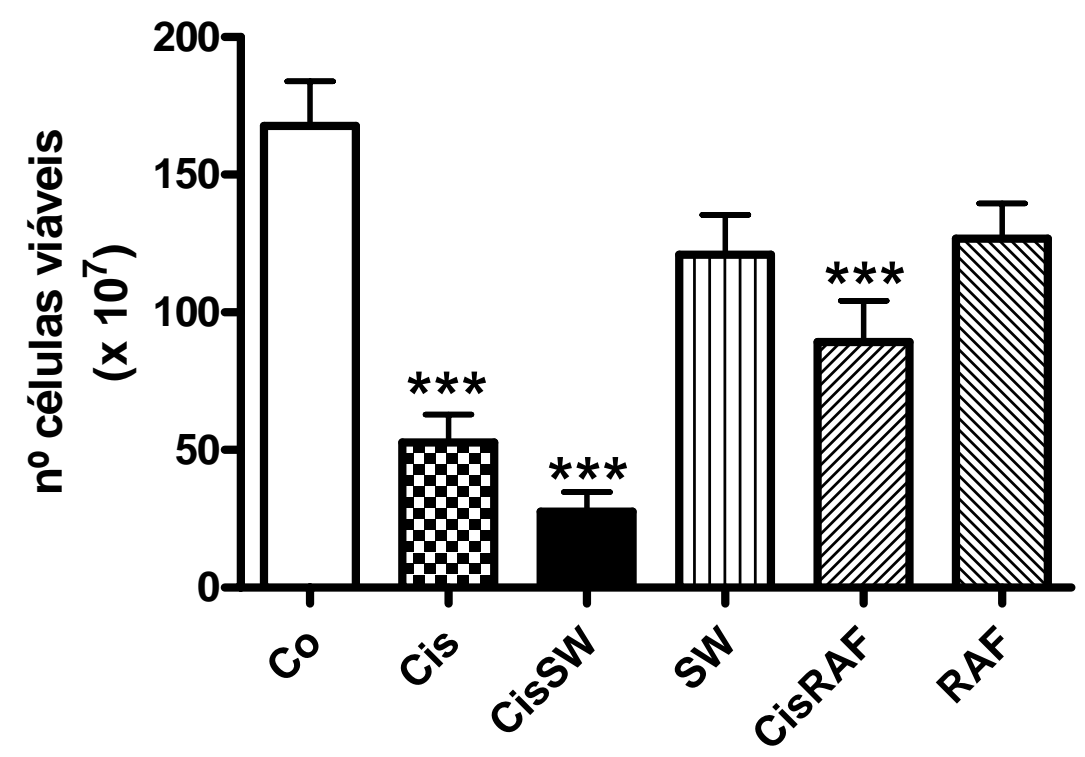

Figura 32: Número total de células tumorais viáveis provenientes de camundongos C57BL/6 inoculados com tumor ascítico de Ehrlich e submetidos a diferentes tratamentos: $\mathrm{Co}=$ controle; $\mathrm{Cis}=$ tratado com cisplatina; $\mathrm{CisSW}=$ tratado com cisplatina e suainsonina; $\mathrm{SW}=$ tratado com suainsonina; CisRAF = tratado com cisplatina e fração aquosa de $I$. carnea; RAF = tratado com fração aquosa de $I$. carnea. São apresentadas as médias e os respectivos erros padrões ( $\mathrm{n}=11-12$ por grupo). (ANOVA - pós teste de Dunnett's ${ }^{* *} p<0,001$, quando comparado com o grupo controle) 
Tabela 11: Número total de células viáveis, número total de células tumorais inviáveis e porcentagem de células tumorais inviáveis de camundongos C57BL/6 inoculados com tumor ascítico de Ehrlich e submetidos a diferentes tratamentos: $\mathrm{Co}=$ controle; $\mathrm{Cis}=$ tratado com cisplatina; $\mathrm{CisSW}=$ tratado com cisplatina e suainsonina

\begin{tabular}{|cccc|}
\hline & $\begin{array}{c}\text { Co } \\
(\mathbf{n}=\mathbf{1 0})\end{array}$ & $\begin{array}{c}\text { Cis } \\
(\mathbf{n}=\mathbf{1 1})\end{array}$ & $\begin{array}{c}\text { CisSW } \\
(\mathbf{n}=\mathbf{8})\end{array}$ \\
\hline $\begin{array}{c}\text { Número total de células } \\
\text { tumorais viáveis }\left(\mathbf{x} \mathbf{1 0}^{\mathbf{7}}\right)\end{array}$ & $167,7 \pm$ & $52,73 \pm$ & $27,53 \pm$ \\
\hline $\begin{array}{c}\text { Número total de células } \\
\text { tumorais inviáveis }\left(\mathbf{x} \mathbf{1 0}^{\mathbf{7}}\right)\end{array}$ & 16,20 & 10,21 & 7,23 \\
\hline $\begin{array}{c}\text { Porcentagem de células } \\
\text { tumorais inviáveis (\%) }\end{array}$ & 11,36 & $4,72 \pm$ & $4,62 \pm$ \\
\hline
\end{tabular}

São apresentadas as medias e os respectivos erros padrões (Kruskal-Wallis - pós teste de Dunn's ${ }^{*} p<0,05$, quando comparado com o grupo controle).

\section{Número total de células tumorais}

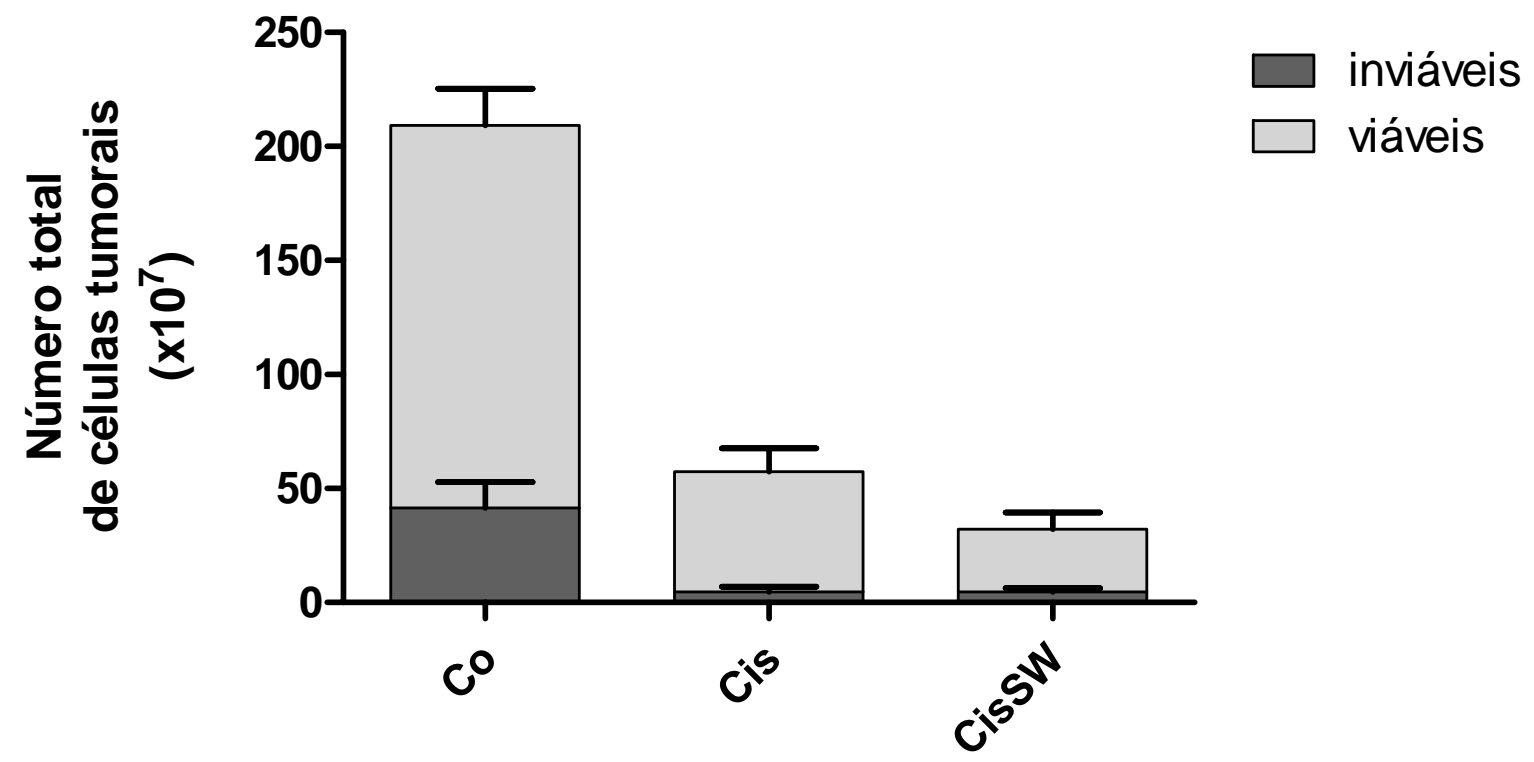

Figura 33: Número total de células tumorais viáveis e inviáveis de camundongos C57BL/6 inoculados com tumor ascítico de Ehrlich e submetidos a diferentes tratamentos: Co = controle; $\mathrm{Cis}=$ tratado com cisplatina; CisSW = tratado com cisplatina e suainsonina 


\section{Porcentagem de células tumorais inviáveis}

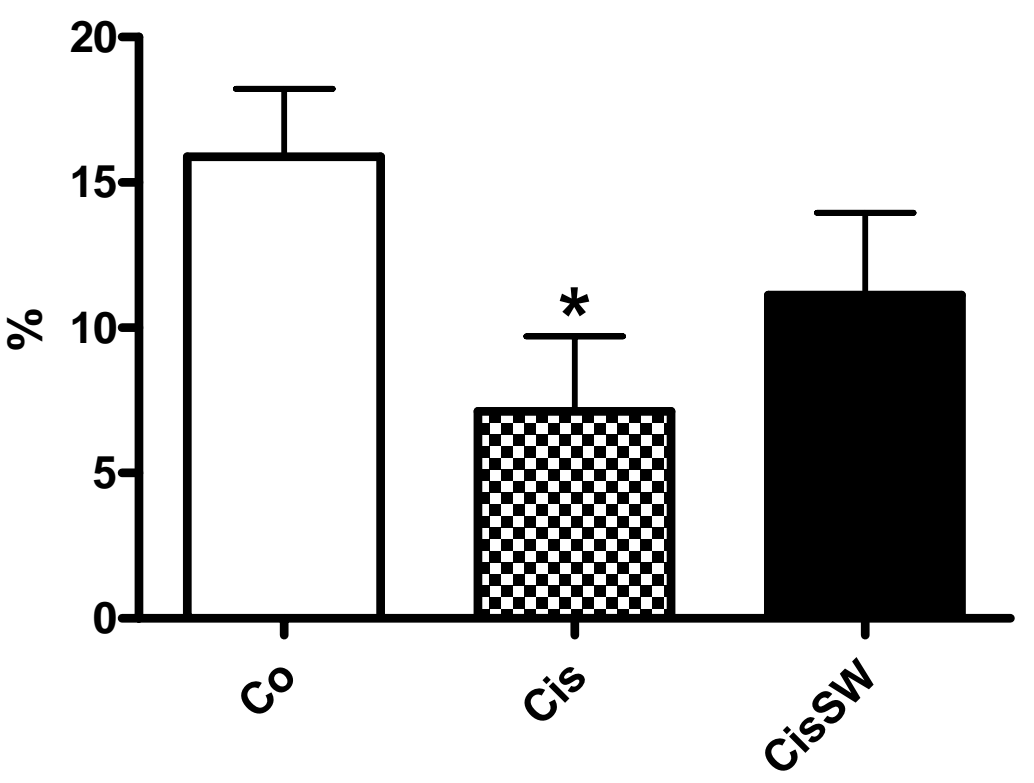

Figura 34: Porcentagem de céluas tumorais inviáveis de camundongos C57BL/6 inoculados com tumor ascítico de Ehrlich e submetidos a diferentes tratamentos: $\mathrm{Co}=$ controle; $\mathrm{Cis}=$ tratado com cisplatina; CisSW = tratado com cisplatina e suainsonina. São apresentadas as médias e os respectivos desvios padrões ( $n=11-12$ por grupo). (Kruskal-Wallis - pós teste de Dunn's - * $p<0,05$, quando comparado com o grupo controle) 


\subsubsection{Citometria de fluxo}

A figura 35 mostra a representação gráfica do ciclo celular de algumas amostras de células tumorais obtidas de camundongos dos diferentes grupos experimentais. Na amostra do grupo controle nota-se que as células em apoptose (sub-G1) apresentam um pico em torno de 200 células; as células em G0/G1 apresentam um pico aproximadamente em 600 células; e as células em G2/M apresentam um pico ao redor de 230 células.

$\mathrm{Na}$ amostra do grupo tratado apenas com a suainsonina (Sw) observou-se que as curva sub-G1 (apoptose) apresentou um pico em torno de 400 células maior que no grupo controle, porém as curvas em G0/G1 e G2/M apresentaram picos semelhantes àquelas do controle, isto é, aproximadamente 600 células na primeira, e em torno de 230 células na fase G2/M.

Na representação gráfica do ciclo celular dos animais tratados apenas com o extrato aquoso da I. carnea (grupo RAF) observou-se que a curva sub-G1 (apoptose) apresentou um pico próximo de 500 células, enquanto as células em G0/G1 apresentam um pico em torno de 700 células, e aquelas na fase G2/M mostraram o pico ao redor de 200 células.

É importante ressaltar que todos os animais dos grupos tratados com a cisplatina (grupos Cis, CisRAF e CisSW) apresentaram pico de células em apoptose maior do que aqueles das demais fases do ciclo celular. No grupo CisRAF (tratado com cisplatina e com o residuo aquoso da l. carnea) observouse grande aumento no número de células em apoptose (se comparado com o grupo controle), chegando a aproximadamente 750 células, enquanto na fase 
G0/G1 notou-se redução do pico (em torno de 500 células), sendo o mesmo achado observado na fase G2/M (ao redor de 200 células).

$\mathrm{Na}$ amostra representativa do ciclo celular do grupo Cis (tratado apesnas com cisplatina) notou-se um pico com mais de 830 células em apoptose, enquanto na curva da fase G0/G1 notou-se um pico de aproximadamente 150 células e em G2/M, pico contendo por volta de 100 células.

A amostra que ilustra o ciclo celular com maiores alterações quando comparado com o grupo controle, foi àquela dos animais do grupo CisSW (tratados simultaneamente com cisplatina e suainsonia). Assim, o pico de células em apoptose (sub-G1) apresentou cerca de 1500 células e, além disso, os picos das curvas das fases G0/G1 e G2/M não ultrapassavam 50 células.

A figura 36 mostra a porcentagem de células do tumor ascítico de Ehrlich em todas as fases do ciclo celular, provenientes de camundongos dos diferentes grupos, enquanto as figuras 37, 38, 39 e 40 ilustram a porcentagem de células em cada uma das fases do ciclo celular dos animais submetidos aos diferentes tratamentos.

Ao avaliar a proporção de células em apoptose (Tabela 12 e Figura 37), ou seja, na fase sub-G1 do ciclo celular, observou-se aumento significante dessa porcentagem em todos os grupos tratados com cisplatina (Cis, CisSW e CisRAF), quando comparados com a proproção de células em apoptose do grupo controle. Vale destacar que os grupos Cis e CisSW apresentaram no pós teste de Dunn's valores de $\mathrm{p}<0,001$, enquanto o grupo tratado com CisRAF, $\mathrm{p}<0,05$ (KruskalWallis - KW=41,85; $p<0,0001$ - pós teste de Dunn's - $p<0,05)$. 
$\mathrm{Na}$ análise da proporção de células na fase G0/G1, fase de crescimento celular, exposta na tabela 12 e na figura 38, observou-se diminuição significante dessa porcentagem em todos os grupos tratados com cisplatina (Cis, CisSW e CisRAF), quando comparados com a proproção de células nesta fase no grupo controle. Vale destacar que os grupos Cis e CisSW apresentaram no pós teste de Dunn's valores de $p<0,001$, enquanto o grupo tratado com CisRAF, $p<0,05$ (Kruskal-Wallis - KW=38,88; $p<0,0001$ - pós teste de Dunn's - $p<0,05$ ).

Quando se avaliou a proporção de células na fase S, fase de duplicação do material genético, (Tabela 12 e na Figura 39) observou-se diminuição significante dessa porcentagem nos grupos Cis e CisSW, quando comparados com a proproção de células na fase $S$ do grupo controle. Vale destacar que os camundongos tratados com cisplatina e suainsonina (CisSW) apresentaram no pós teste de Dunn's valores de $p<0,001$, enquanto o grupo tratado apenas com cisplatina (Cis) apresentaram $\mathrm{p}<0,01$ (Kruskal-Wallis - KW=43,32; $\mathrm{p}<0,0001$ pós teste de Dunn's - $p<0,05)$.

Ao avaliar-se a proporção de células na fase G2 do ciclo celular, ou seja, completando o final da mitose, foi possivel notar a existência de uma diminuição significativa entre a porcentagem de células em G2 dos animais do grupo controle quando comparados aos grupos experimentais Cis e CisSW, porém os animais tratados com cisplatina e suainsonina - CisSW - apresentaram uma diminuição mais significante $(p<0,01)$ do que aqueles tratados apenas com cisplatina - Cis - onde o valor de $p$ foi menor que 0,05. A tabela 12 e a figura 40 (Kruskal-Wallis - KW=28,84; $p<0,0001$ - pós teste de Dunn's - $p<0,05)$ mostram esses dados. 

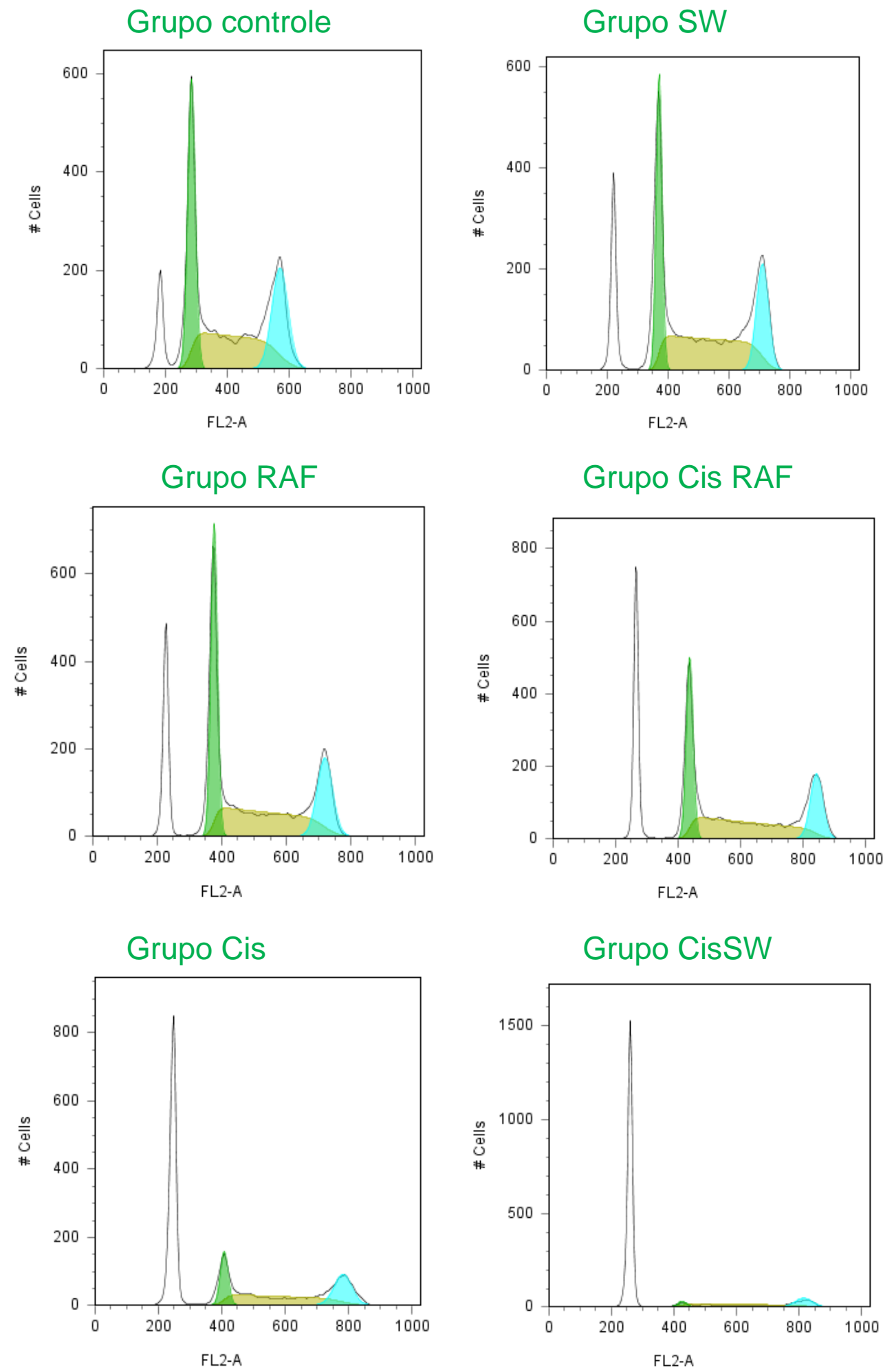

Figura 35: Histogramas de ciclos celulares (avaliados por citometria de fluxo) obtidos de células tumorais provenientes de camundongos C57BL/6 inoculados com tumor ascítico de Ehrlich e submetidos a diferentes tratamentos: Controle; $\mathrm{Cis}=$ tratado com cisplatina; CisSW = tratado com cisplatina e suainsonina; $\mathrm{SW}=$ tratado com suainsonina; CisRAF = tratado com cisplatina e fração aquosa de $I$. carnea; RAF = tratado com fração aquosa de $I$ carnea. Fase sub-G1 ou apoptose = pico sem preenchimento; fase G0/G1 = pico de cor verde; fase $S$ = pico de cor marrom; e fase $\mathrm{G} 2 / \mathrm{M}$ = pico cor azul. As ilustrações mostram dados obtidos de apenas um animal do grupo em questão 


\section{RESULTADOS}

Tabela 12: Porcentagem de células tumorais nas fases sub-G1; G0/G1; S e G2/M, obtidas de camundongos C57BL/6 inoculados com tumor ascítico de Ehrlich e submetidos a diferentes tratamentos: $\mathrm{Co}=$ controle; $\mathrm{Cis}=$ tratado com cisplatina; CisSW = tratado com cisplatina e suainsonina; $\mathrm{SW}=$ tratado com suainsonina; CisRAF = tratado com cisplatina e fração aquosa de $I$. carnea; RAF = tratado com fração aquosa de $I$. carnea

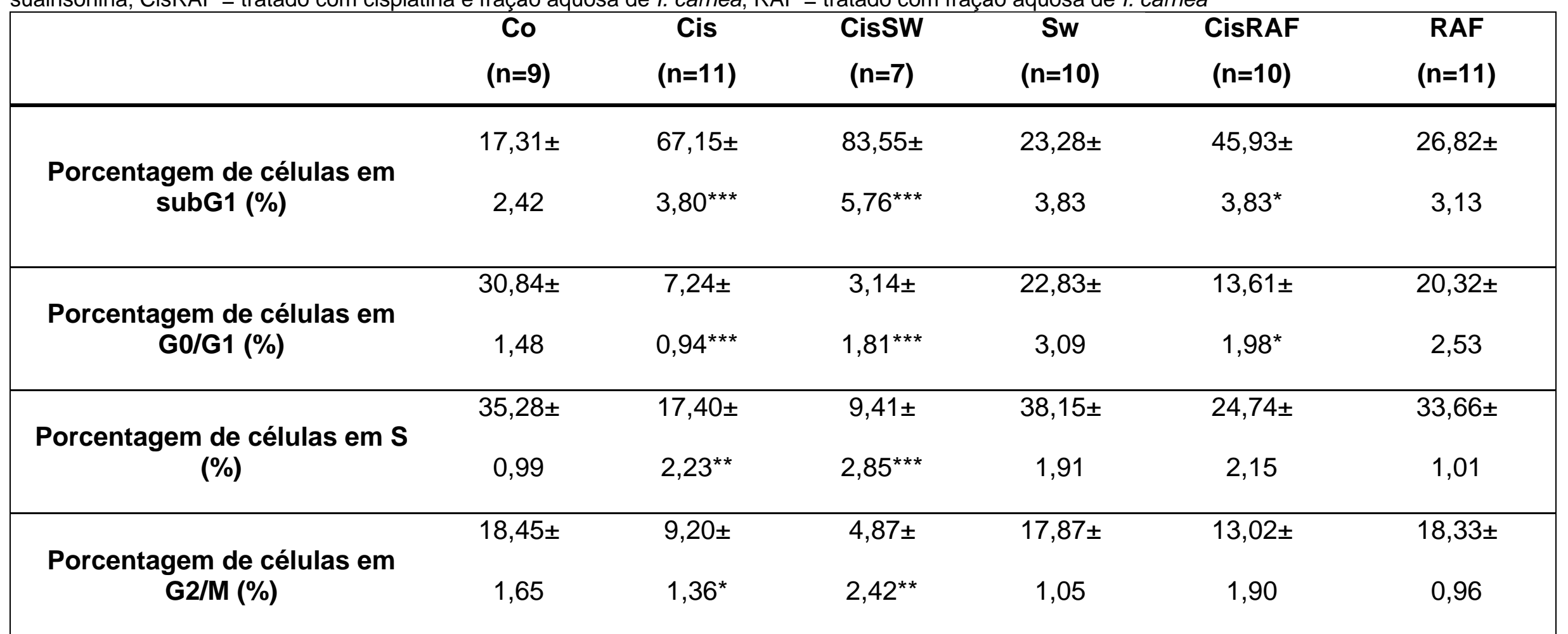

São apresentadas as médias e os respectivos erros padrões (Kruskal-Wallis - pós teste de Dunn's - ${ }^{\star} p<0,05$; ${ }^{* \star} p<0,01 ;{ }^{* * \star} p<0,001$, quando comparado com o grupo controle). 


\section{Ciclo celular}

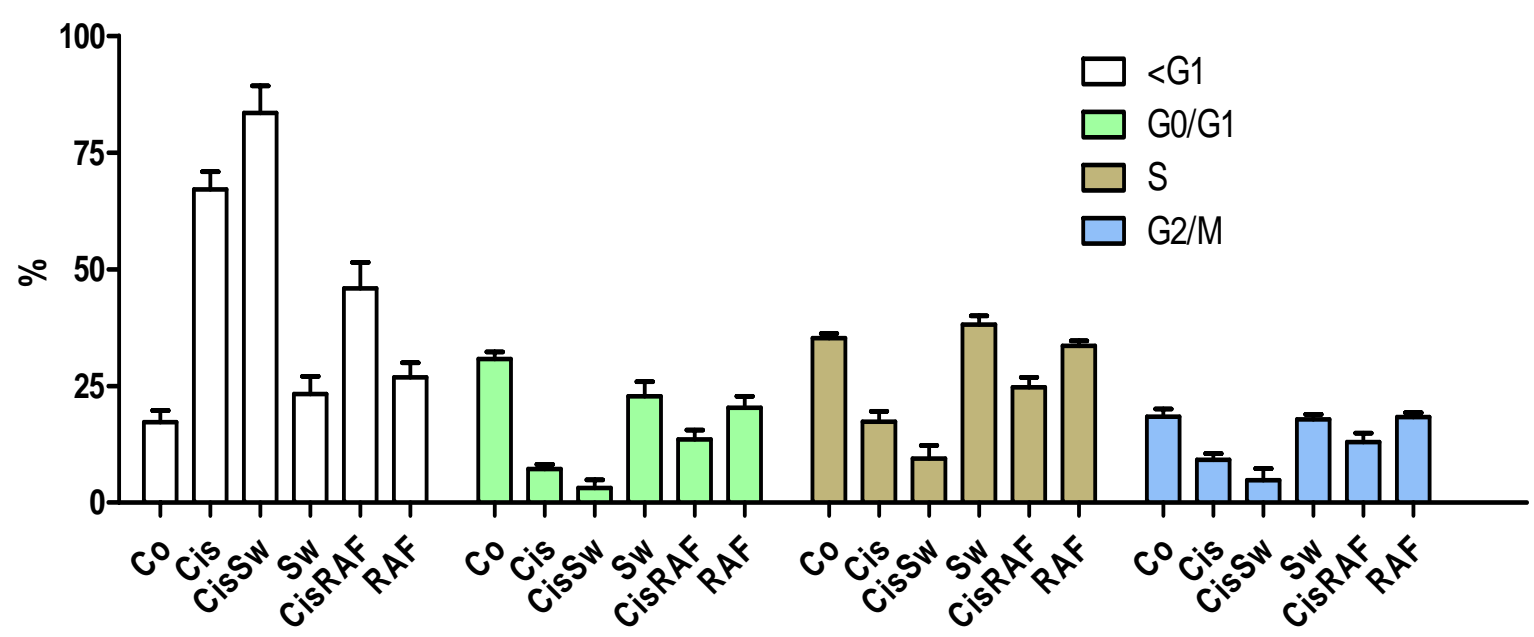

Figura 36: Porcentagem de células tumorais, avaliadas por citometria de fluxo, nas diferentes fases do ciclo celular (<G1; G0/G1; S; G2/M), provenientes de camundongos C57BL/6 inoculados com tumor ascítico de Ehrlich e submetidos a diferentes tratamentos: Co = controle; Cis = tratado com cisplatina; $\mathrm{CisSW}=$ tratado com cisplatina e suainsonina; $\mathrm{SW}=$ tratado com suainsonina; CisRAF = tratado com cisplatina e fração aquosa de $I$. carnea; RAF = tratado com fração aquosa de $I$. carnea. São apresentadas as médias e os respectivos erros padrões ( $n=7-11$ por grupo)

\section{Porcentagem de células tumorais em fase sub-G1 (apoptose)}

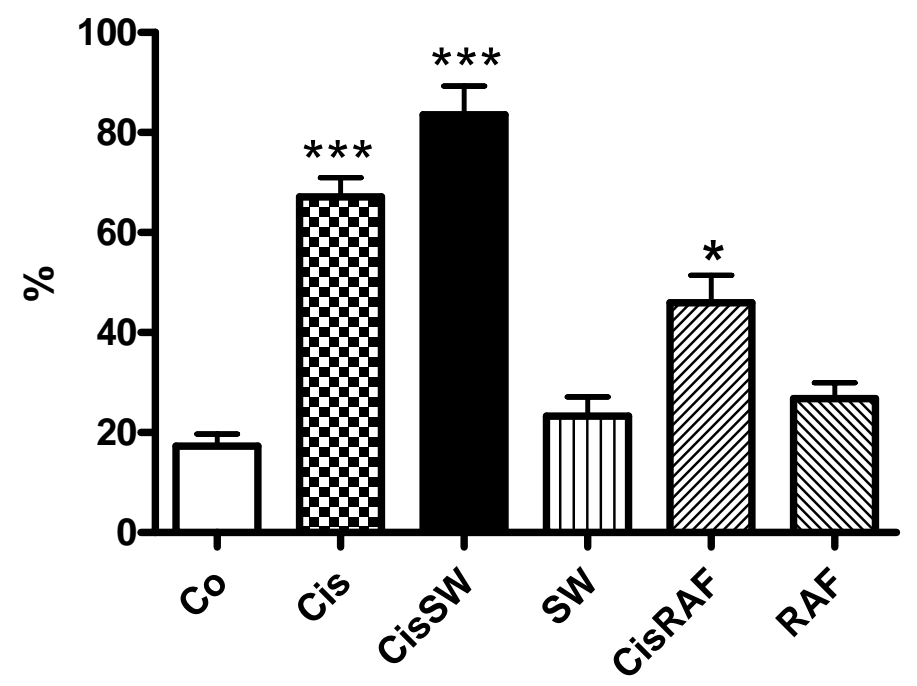

Figura 37: Porcentagem de células tumorais em apoptose (fase sub-G1) obtidas de camundongos C57BL/6 inoculados com tumor ascítico de Ehrlich e submetidos a diferentes tratamentos: $\mathrm{Co}=$ controle; $\mathrm{Cis}=$ tratado com cisplatina; $\mathrm{CisSW}=$ tratado com cisplatina e suainsonina; $\mathrm{SW}=$ tratado com suainsonina; CisRAF = tratado com cisplatina e fração aquosa de $I$. carnea; RAF = tratado com fração aquosa de $I$. carnea. São apresentadas as médias e os respectivos erros padrões ( $\mathrm{n}=7-11$ por grupo). (Kruskal-Wallis - pós teste de Dunn's ${ }^{*} \mathrm{p}<0,05 ;{ }^{* \star} \mathrm{p}<0,001$, quando comparado com o grupo controle) 


\section{Porcentagem de células tumorais em fase G0/G1}

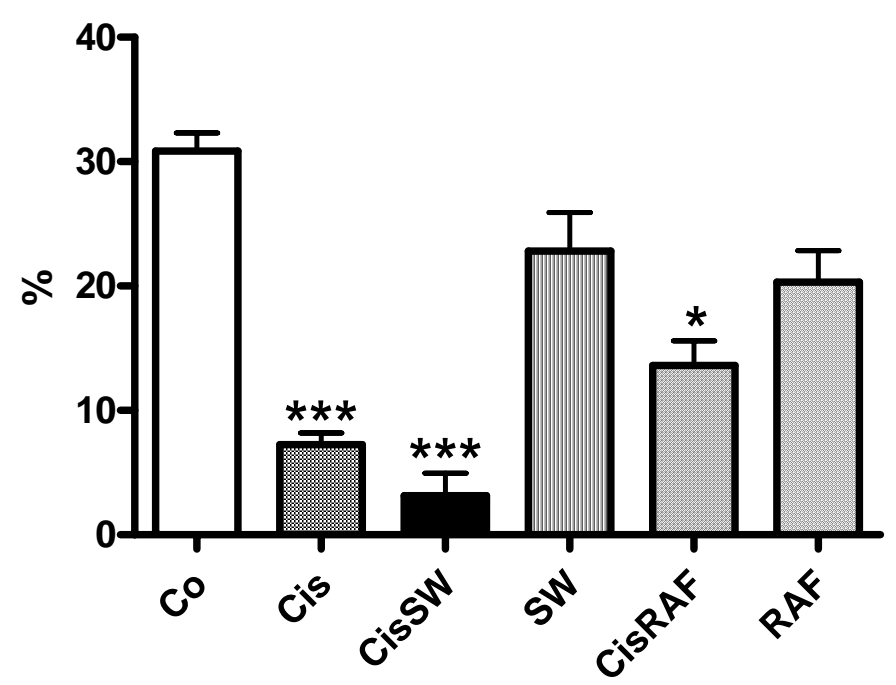

Figura 38: Porcentagem de células tumorais na fase G0/G1 obtidas de camundongos C57BL/6 inoculados com tumor ascítico de Ehrlich e submetidos a diferentes tratamentos: Co = controle; $\mathrm{Cis}=$ tratado com cisplatina; $\mathrm{CisSW}=$ tratado com cisplatina e suainsonina; $\mathrm{SW}=$ tratado com suainsonina; CisRAF = tratado com cisplatina e fração aquosa de $I$. carnea; RAF = tratado com fração aquosa de $I$. carnea. São apresentadas as médias e os respectivos erros padrões ( $\mathrm{n}=7-11$ por grupo). (Kruskal-Wallis - pós teste de Dunn's ${ }^{*} p<0,05 ;{ }^{* \star *} p<0,001$, quando comparado com o grupo controle)

\section{Porcentagem de células tumorais em fase $S$}

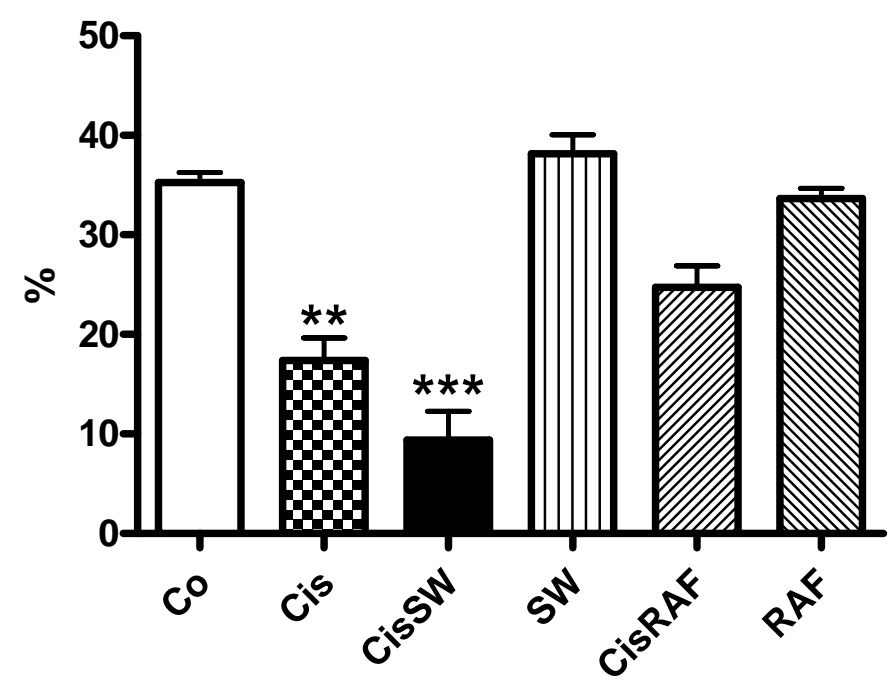

Figura 39: Porcentagem de células tumorais na fase $S$ obtidas de camundongos C57BL/6 inoculados com tumor ascítico de Ehrlich e submetidos a diferentes tratamentos: Co = controle; Cis = tratado com cisplatina; CisSW = tratado com cisplatina e suainsonina; SW = tratado com suainsonina; CisRAF = tratado com cisplatina e fração aquosa de $I$. carnea; RAF = tratado com fração aquosa de $I$. carnea. São apresentadas as médias e os respectivos erros padrões ( $n=7-11$ por grupo). Kruskal-Wallis - pós teste de Dunn's - ${ }^{\star \star} p<0,01 ;{ }^{* \star} p<0,001$, quando comparado com o grupo controle) 


\section{Porcentagem de células tumorais em fase G2/M}

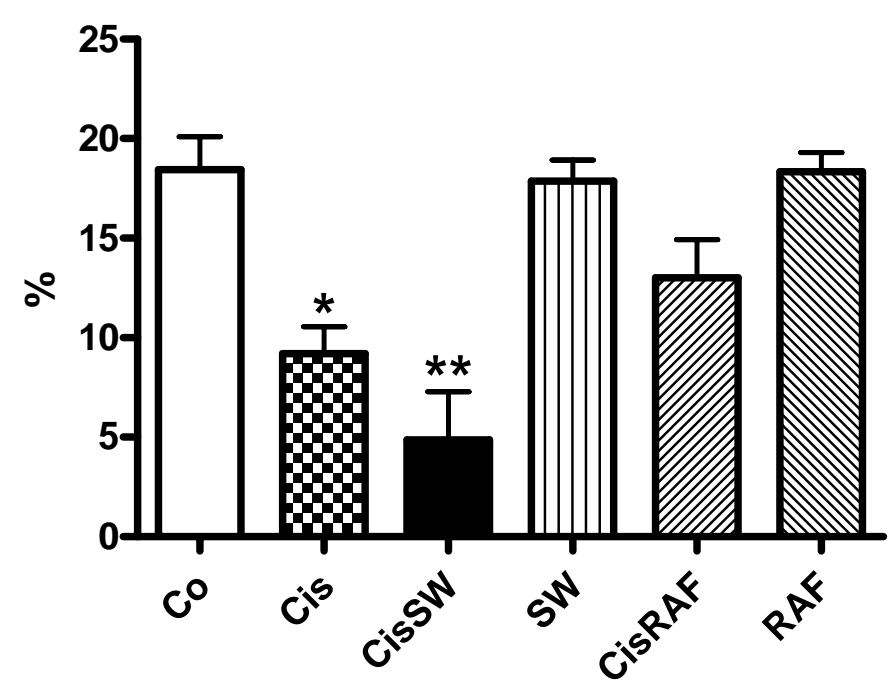

Figura 40: Porcentagem de céluas na fase G2/M do ciclo celular, células tumorais de camundongos C57BL/6 inoculados com tumor ascítico de Ehrlich e submetidos a diferentes tratamentos: $\mathrm{Co}=$ controle; $\mathrm{Cis}=$ tratado com cisplatina; CIS-SW = tratado com cisplatina $\mathrm{e}$ suainsonina; $\mathrm{SW}=$ tratado com suainsonina; $\mathrm{CIS}-\mathrm{AF}=$ tratado com cisplatina e fração aquosa de Ipomoea carnea; AF = tratado com fração aquosa de I. carnea. São apresentadas as medias e os respectivos erros padrões ( $\mathrm{n}=7-11$ por grupo). (KruskalWallis - pós teste de Dunn's - ${ }^{\star} p<0,05$; ${ }^{\star \star} p<0,01$, quando comparado com o grupo controle)

\subsubsection{Análise Sanguínea}

Em relação à análise bioquímica sérica, ao se avaliar as concentrações séricas da creatina não foi possível notar diferença estatística entre os grupos (ANOVA, $F=1,191 ; d f=6 / 58 ; p=0,3237$ - Tabela 13).

Notou-se diferença significante na avaliação da concentração sérica de uréia entre os grupos controle e CisSW. Os animais tratados com cisplatina e suainsonina (CisSW) apresentaram uma diminuição da concentração sérica de uréia quando comparado aos animais do grupo controle (ANOVA - F=2,583 df $=6 / 58 ; p=0,0275$ - pós teste de Dunnett's $-p<0,05)$ - Tabela 13 e Figura 41 . É importante ressaltar não há diferenças significantes entre o grupo Branco (os 
animais não receberam nem o tumor ascítico de Ehrlich nem qualquer tratamento) e os demais grupos (Controle e tratados).

Os animais tratados com cisplatina e suainsonina (CisSW) apresentaram uma diminuição da concentração na ALT sérica quando comparado aos animais do grupo Branco (ANOVA - F=4,991; df=6/58; $p=0,0004$ - pós teste de Dunnett's - $p<0,05)$ - Tabela 13 e Figura 42. É importante frisar que nenhum dos grupos experimentais quanto foram comparados aos animais do grupo Controle apresentou diferenças estatísticas.

A tabela 14 mostra os parâmetros hematológicos de camundongos C57BL/6 inoculados com tumor ascítico de Ehrlich e submetidos a diferentes tratamentos. A análise estatística não revelou diferenças significantes no número de leucócitos; número de hemácias; quantidade de hemoglobina; hematócrito; volume corpuscular médio - VCM; hemoglobina corpuscular média - HCM; concentração de hemoglobina corpuscular média - $\mathrm{CHCM}$; e plaquetas entre os diferentes grupos (branco, controle, Cis, CisSW, SW, CisRAF, e RAF). 


\section{RESULTADOS}

Tabela 13: Creatina, uréia e ALT sérica de camundongos C57BL/6 inoculados com tumor ascítico de Ehrlich e submetidos a diferentes tratamentos: branco (não inoculado); controle; $\mathrm{Cis}=$ tratado com cisplatina; CIS-SW = tratado com cisplatina e suainsonina; SW = tratado com suainsonina; CIS-RAF = tratado com cisplatina e fração aquosa de Ipomoea carnea; RAF = tratado com fração aquosa de l. carnea

\begin{tabular}{|c|c|c|c|c|c|c|c|}
\hline & $\begin{array}{c}\mathrm{Br} \\
(n=11)\end{array}$ & $\begin{array}{c}\text { Co } \\
(n=9)\end{array}$ & $\begin{array}{c}\text { Cis } \\
(n=11)\end{array}$ & $\begin{array}{c}\text { CissW } \\
(n=8)\end{array}$ & $\begin{array}{c}\text { Sw } \\
(n=8)\end{array}$ & $\begin{array}{c}\text { CisRAF } \\
(n=9)\end{array}$ & $\begin{array}{l}\text { RAF } \\
(n=9)\end{array}$ \\
\hline \multirow[t]{2}{*}{ Creatina (mg/dL) } & & & & $0,36 \pm$ & & & \\
\hline & 0,06 & 0,08 & 0,05 & 0,08 & 0,09 & 0,06 & 0,10 \\
\hline \multirow[t]{2}{*}{ Uréia (mg/dL) } & & $90,84 \pm$ & $71,21 \pm$ & $64,90 \pm$ & $80,32 \pm$ & $74,03 \pm$ & \\
\hline & 3,09 & 6,37 & 4,08 & $2,77^{*}$ & 3,95 & 3,23 & 12,29 \\
\hline \multirow[t]{2}{*}{ ALT (U/L) } & $15,33 \pm$ & $13,50 \pm$ & $9,48 \pm$ & $8,25 \pm$ & $19,25 \pm$ & $11,23 \pm$ & $17,57 \pm$ \\
\hline & 1,41 & 1,90 & 1,35 & $1,22^{\#}$ & 3,34 & 1,29 & 1,78 \\
\hline
\end{tabular}

São apresentadas as médias e os respectivos erros padrões (ANOVA, pós teste de Dunnett's - ${ }^{*} p<0,05$, quando comparado ao grupo controle - ${ }^{\#} p<0,05$, quando comparado ao grupo branco). 


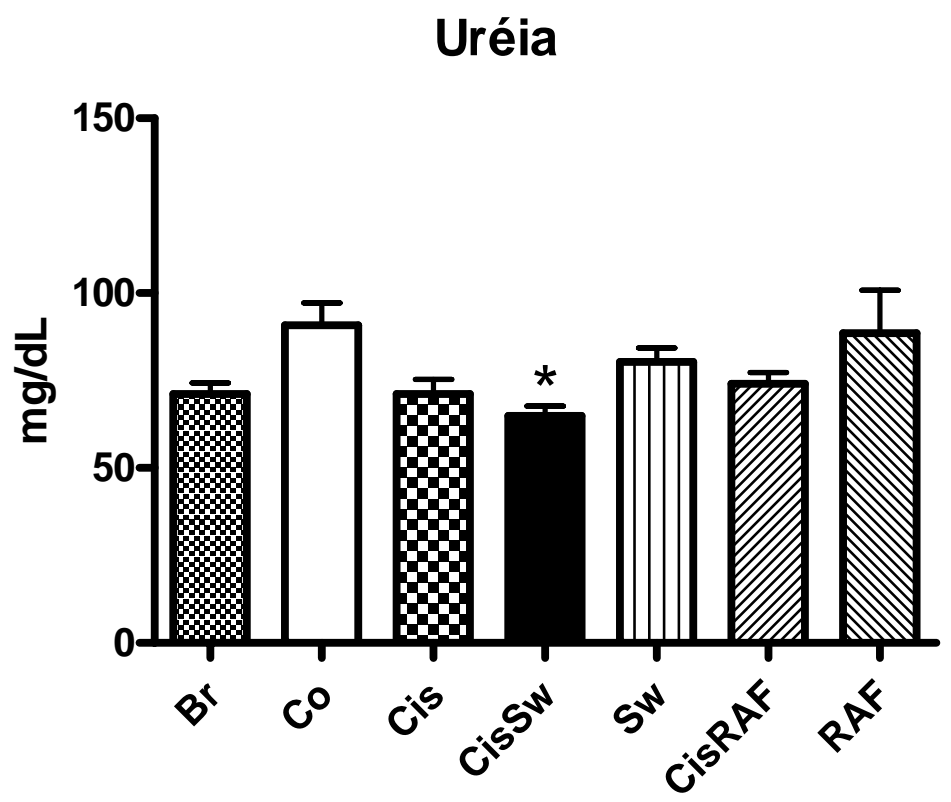

Figura 41: Uréia sérica de camundongos C57BL/6 inoculados com tumor ascítico de Ehrlich e submetidos a diferentes tratamentos: branco (não inoculado); controle; Cis = tratado com cisplatina; CIS-SW = tratado com cisplatina e swainsonina; SW = tratado com suainsonina; CIS-RAF = tratado com cisplatina e fração aquosa de Ipomoea carnea; RAF = tratado com fração aquosa de l. carnea. São apresentadas as medias e os respectivos erros padrões ( $n=8-11$ por grupo). (ANOVA - pós teste de Dunnett's - * $p<0,05$, quando comparado com 0 grupo controle)

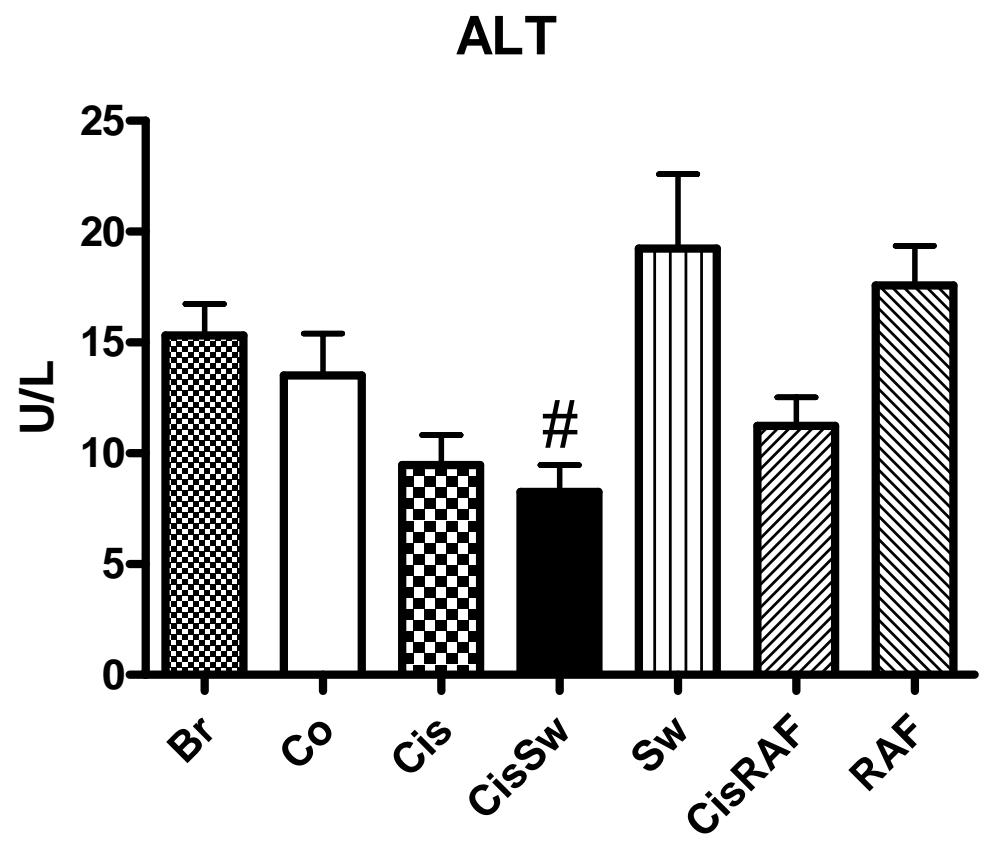

Figura 42: ALT sérica de camundongos C57BL/6 inoculados com tumor ascítico de Ehrlich e submetidos a diferentes tratamentos: branco (não inoculado); controle; $\mathrm{Cis}=$ tratado com cisplatina; CIS-SW = tratado com cisplatina e swainsonina; $\mathrm{SW}=$ tratado com suainsonina; CIS-RAF = tratado com cisplatina e fração aquosa de Ipomoea carnea; RAF = tratado com fração aquosa de $I$. carnea. São apresentadas as medias e os respectivos erros padrões ( $n=8-11$ por grupo). (ANOVA - pós teste de Dunnett's - " $p<0,05$, quando comparado com o grupo branco) 
Tabela 14: Parâmetros hematológicos de camundongos C57BL/6 inoculados com tumor ascítico de Ehrlich e submetidos a diferentes tratamentos: branco (não inoculado); controle; $\mathrm{Cis}=$ tratado com cisplatina; CIS-SW = tratado com cisplatina e suainsonina; SW = tratado com suainsonina; CIS-RAF = tratado com cisplatina e fração aquosa de Ipomoea carnea; RAF = tratado com fração aquosa de $I$. carnea

\begin{tabular}{|c|c|c|c|c|c|c|c|}
\hline & $\begin{array}{l}\text { Branco } \\
(n=11)\end{array}$ & $\begin{array}{c}\text { Controle } \\
(n=10)\end{array}$ & $\begin{array}{c}\text { Cis } \\
(n=11)\end{array}$ & $\begin{array}{l}\text { CisSW } \\
(n=12)\end{array}$ & $\begin{array}{c}\text { SW } \\
(n=12)\end{array}$ & $\begin{array}{l}\text { CisRAF } \\
(n=11)\end{array}$ & $\begin{array}{l}\text { RAF } \\
(n=11)\end{array}$ \\
\hline \multirow{2}{*}{$\begin{array}{c}\text { Hematócrito } \\
\text { (\%) }\end{array}$} & 30,20 & 27,76 & 27,27 & 27,33 & 28,31 & 28,20 & 27,94 \\
\hline & $\pm 1,14$ & $\pm 0,86$ & $\pm 1,34$ & $\pm 1,81$ & $\pm 1,29$ & $\pm 0,96$ & $\pm 1,01$ \\
\hline \multirow{2}{*}{$\begin{array}{l}\text { Hemoglo- } \\
\text { bina (g/dL) }\end{array}$} & 12,83 & 12,29 & 12,08 & 11,91 & 12,31 & 12,21 & 12,12 \\
\hline & $\pm 0,30$ & $\pm 0,29$ & $\pm 0,34$ & $\pm 0,64$ & $\pm 0,45$ & $\pm 0,32$ & $\pm 0,34$ \\
\hline \multirow[b]{2}{*}{$\begin{array}{l}\text { Hemácias } \\
\left(10^{6} / \mathrm{mm}^{3}\right)\end{array}$} & 8,33 & 7,72 & 7,57 & 7,51 & 7,90 & 7,90 & 7,83 \\
\hline & $\pm 0,27$ & $\pm 0,23$ & $\pm 0,36$ & $\pm 0,49$ & $\pm 0,33$ & $\pm 0,22$ & $\pm 0,24$ \\
\hline \multirow[b]{2}{*}{$\begin{array}{l}\text { Leucócitos } \\
\left(10^{3} / \mathrm{mm}^{3}\right)\end{array}$} & 12,37 & 10,67 & 10,48 & 8,90 & 8,08 & 10,98 & 9,59 \\
\hline & $\pm 1,57$ & $\pm 1,74$ & $\pm 0,94$ & $\pm 1,01$ & $\pm 1,24$ & $\pm 1,79$ & $\pm 2,24$ \\
\hline \multirow[b]{2}{*}{$\begin{array}{l}\text { Plaquetas } \\
\left(10^{3} / \mathrm{mm}^{3}\right)\end{array}$} & 364,5 & 438,2 & 391,5 & 317,7 & 456,8 & 404,0 & 414,3 \\
\hline & $\pm 52,73$ & $\pm 82,09$ & $\pm 58,41$ & $\pm 45,62$ & $\pm 41,93$ & $\pm 64,20$ & $\pm 55,81$ \\
\hline \multirow[b]{2}{*}{$\begin{array}{l}\text { VCM } \\
\left(\mathrm{fm}^{3}\right)\end{array}$} & 36,36 & 36,10 & 36,00 & 36,42 & 35,83 & 35,82 & 35,45 \\
\hline & $\pm 0,41$ & $\pm 0,31$ & $\pm 0,35$ & $\pm 0,43$ & $\pm 0,34$ & $\pm 0,26$ & $\pm 0,36$ \\
\hline \multirow{2}{*}{$\begin{array}{c}\mathrm{HCM} \\
(\mathrm{pg})\end{array}$} & 15,45 & 15,94 & 16,13 & 16,00 & 15,64 & 15,47 & 15,39 \\
\hline & $\pm 0,23$ & $\pm 0,24$ & $\pm 0,36$ & $\pm 0,29$ & $\pm 0,18$ & $\pm 0,19$ & $\pm 0,24$ \\
\hline \multirow{2}{*}{$\begin{array}{l}\text { CHCM } \\
\text { (g/dL) }\end{array}$} & 42,72 & 44,37 & 44,85 & 44,05 & 43,68 & 43,52 & 43,52 \\
\hline & $\pm 0,80$ & $\pm 0,58$ & $\pm 1,15$ & $\pm 0,92$ & $\pm 0,62$ & $\pm 0,72$ & $\pm 0,72$ \\
\hline
\end{tabular}

São apresentadas as médias e os respectivos erros padrões (Kruskal-Wallis - ANOVA - $p<0,05)$. 


\subsubsection{Análise histopatológica}

O quadro 8 e a figura 43 apresentam a compilação dos principais achados histopatológicos do tecido hepático dos grupos branco, controle e dos diferentes grupos experimentais. Os animais do grupo branco não apresentaram alterações dignas de nota, o quadro histológico estava dentro da normalidade. Os camundongos do grupo controle apresentaram raros hepatócitos binucleados, fato também observado nos animais do grupo branco, porém estavam dentro do padrão histopatológico da normalidade. Nestes animais foi observada, em algumas lâminas, a presença de células neoplásicas em torno da cápsula hepática.

Nos animais pertencentes ao grupo CIS (tratados apenas com cisplatina) e os do grupo CisSW (tratados com cisplatina e suainsonina) apresentaram lâminas histológicas semelhantes, nestas foi observada poliploidia, caracterizada pelo aumeto de células binucleadas e pela presença de células com cario e citomegalia. Outra alteração observada foi um aumento acentuado de células hepáticas em mitose, muitas destas apresentavam mitoses atípicas. Não foram notadas outras alterações dignas de nota.

Os camundongos do grupo SW (tratados com suainsonina) e CISRAF (cisplatina e RAF) além das alterações observadas nos grupos supracitados, foram observadas, em algumas lâminas, células neoplásicas em torno da cápsula hepática. Não foram observadas outras alterações dignas de nota.

Os animais do grupo RAF (tratados com o resíduo aquoso final da I.carnea) apresentaram um aumento discreto no número de células binucleadas, e em algumas lâminas, notaram-se células neoplásicas em torno da cápsula 
hepática. As demais relações histplógicas permaneceram sem alterações perceptíveis.

Em relação às alterações histopatológicas observadas no tecido renal destes animais (dados estão apresentados no quadro 9 e na figura 44); foi possível visualizar que os animais do grupo branco e aqueles pertencentes ao grupo controle tiveram preservação da arquitetura do parênquima renal, além disso, os glomérulos estavam livres de processos patológicos. Nos camundongos do grupo controle notou-se a presença, em algumas lâminas histopatológicas, de células neoplásicas em torno da cápsula renal.

Nos animais do grupo CIS, pode-se observar em alguns cortes histológicos a presença de proteinúria nos túbulos proximais. As demais relações histológicas estavam semelhantes às dos animais do grupo branco; este fato também foi observado em algumas lâminas do grupo CisSW. Outro quadro que pode ser notado foi a existência de uma discreta glomerulonefrite membranoproliferativa multifocal segmentar em alguns animais deste grupo.

Nas lâminas dos grupos SW, CISRAF, e RAF não foi possível observar alterações dignas de nota em nenhuma das lâminas hitológicas do tecido renal. Vale frisar que em algumas destas lâminas foi possível notar células neoplásicas em torno da cápsula renal, além disso, cabe a observação de que em alguns cortes histológicos de animais do grupo RAF foi perceptível um discreto espessamento da membrana basal.

A análise do material histopatológico esplênico, compilada no quadro 10 e na figura 45, mostrou que os camundongos do grupo branco apresentaram um quadro histológico dentro dos padrões de normalidade, com a presença de raros 
megacariócitos no parênquima do órgão. O mesmo foi observado nos animais do grupo controle (inoculados com o tumor ascítico de Ehrlich), porém, em alguns cortes histológicos, observou-se discreta hemossiderose e, em outros cortes, foi observada a existência de células neoplásicas em torno da cápsula do baço.

As lâminas histopatológicas do baço de animais dos diferentes grupos experimentais (Cis, CisSW, SW, CISRAF, e RAF) apresentaram hemossiderose (com uma variação entre discreta a moderada). Em alguns animais notou-se a existência de células neoplásicas em torno da cápsula esplênica. Além disso, ocorreu um discreto aumento do número de megacariócitos em todos os grupos experimentais.

\begin{tabular}{|c|c|}
\hline Grupos & Descrição histopatológica de tecido hepático \\
\hline Branco & $>$ Quadro histológico dentro do padrão da normalidade; \\
& $>$ Raros hepatócitos binucleados. \\
& $>$ Quadro histológico dentro do padrão da normalidade; \\
& $>$ Raros hepatócitos binucleados. \\
Controle & $>$ Demais relações histológicas semelhantes ao grupo branco \\
& $>$ Alguns animais apresentaram células neoplásicas em torno da \\
& cápsula hepática. \\
\hline CIS & Poliploidia observada por discreto a moderado aumento dos \\
& cariomegalia; \\
& $>$ Aumento acentuado do número de mitoses evidentes, das \\
& quais muitas apresentando mitoses atípicas; \\
$(\mathbf{0 , 2 5 m g / k g ) ~}$ & Foi possível notar a presença de êmbolos neoplásicos em \\
& vasos. \\
& $>$ Demais relações histológicas semelhantes ao grupo branco.
\end{tabular}

Quadro 8: Descrição histopatológica de tecido hepático de camundongos C57BL/6 inoculados com o tumor ascítico de Ehrlich e submetidos a diferentes tratamentos: branco (não inoculado); controle; Cis $=$ tratado com cisplatina 


\begin{tabular}{|c|c|}
\hline CIS-SW & $\begin{array}{l}\text { Poliploidia observada por aumento do número de hepatócitos } \\
\text { binucleados; } \\
\text { Aumento moderado do número de mitoses evidentes, das } \\
\text { quais muitas apresentando mitoses atípicas; } \\
>\text { Demais relações histológicas semelhantes ao grupo branco; } \\
>\text { Alguns animais apresentaram células neoplásicas em torno da } \\
\text { cápsula hepática. }\end{array}$ \\
\hline SW & $\begin{array}{l}\text { Poliploidia observada por discreto aumento do número de } \\
\text { hepatócitos binucleados; } \\
\text { Aumento discreto do número de mitoses evidentes, das quais } \\
\text { muitas apresentando mitoses atípicas; } \\
>\text { Demais relações histológicas semelhantes ao grupo branco; } \\
>\text { Alguns animais apresentaram células neoplásicas em torno da } \\
\text { cápsula hepática }\end{array}$ \\
\hline CIS-RAF & $\begin{array}{l}>\text { Poliploidia observada por aumento do número de hepatócitos } \\
\text { binucleados; } \\
\text { Aumento discreto do número de mitoses evidentes, das quais } \\
\text { muitas apresentando atípicas; } \\
>\text { Demais relações histológicas semelhantes ao grupo branco; } \\
>\text { Alguns animais apresentaram células neoplásicas em torno da } \\
\text { cápsula hepática }\end{array}$ \\
\hline RAF & $\begin{array}{l}\text { Notou-se poliploidia, observada por discretos hepatócitos } \\
\text { binucleados; } \\
>\text { Demais relações histológicas semelhantes ao grupo branco. }\end{array}$ \\
\hline
\end{tabular}

CONTINUAÇÃO do Quadro 8: Descrição histopatológica de tecido hepático de camundongos C57BL/6 inoculados com o tumor ascítico de Ehrlich e submetidos a diferentes tratamentos: CIS-SW = tratado com cisplatina e swainsonina; SW = tratado com suainsonina; CIS-RAF = tratado com cisplatina e fração aquosa de Ipomoea carnea; RAF = tratado com fração aquosa de $I$. carnea 


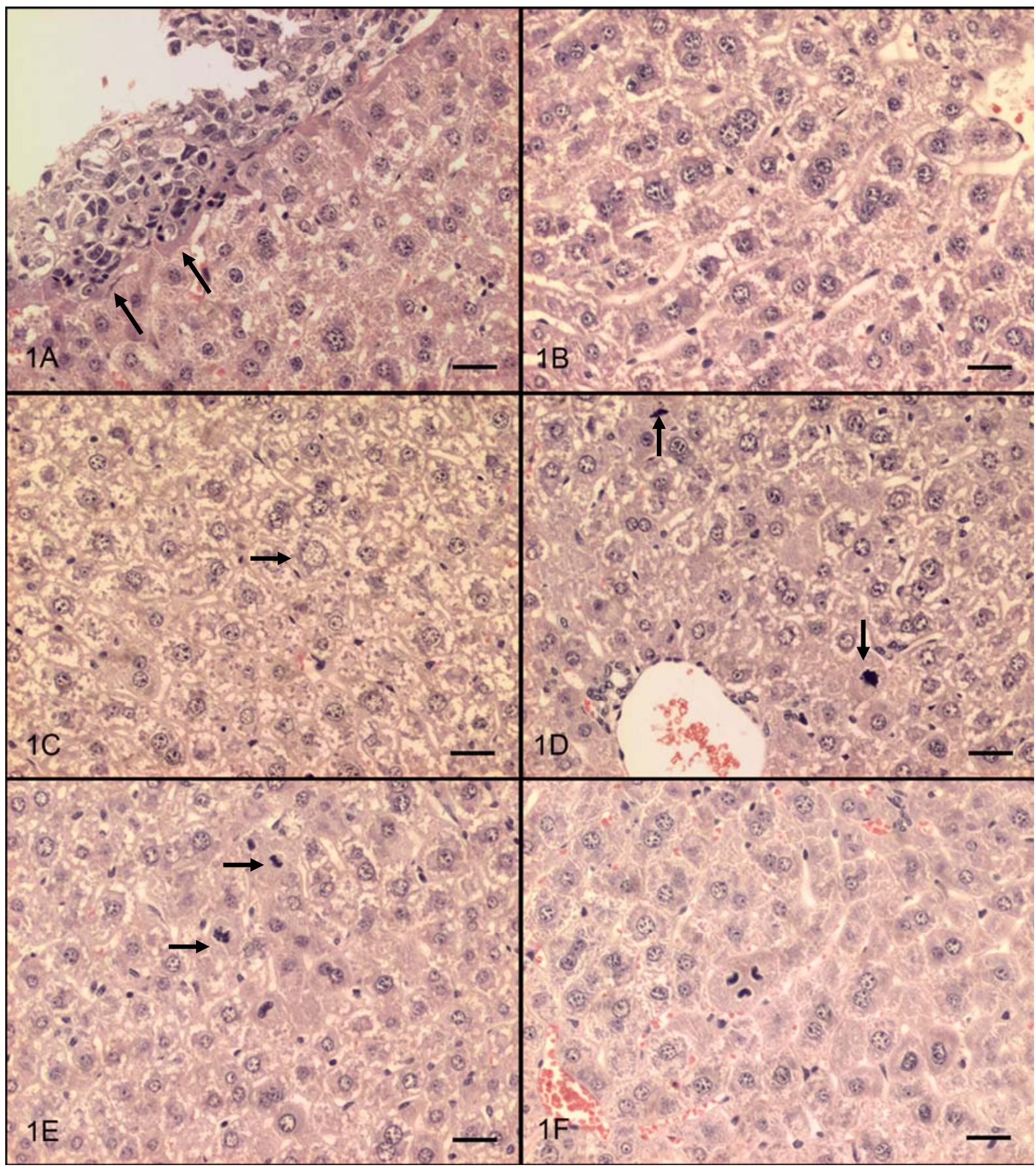

Figura 43: Fotomicrografias dos principais achados hepáticos de camundongos C57BL/6 inoculados com o tumor ascítico de Ehrlich e submetidos a diferentes tratamentos: branco (não inoculado); controle; Cis = tratado com cisplatina; CIS-SW = tratado com cisplatina e swainsonina; SW = tratado com suainsonina; CIS-RAF = tratado com cisplatina e fração aquosa de Ipomoea carnea; RAF = tratado com fração aquosa de $I$. carnea. $1 \mathrm{~A}$ células aderidas à cápsula hepática indicadas pelas setas, grupo controle (barra 20 $\mu \mathrm{m}$ ). 1B hepatócitos binucleados, grupo CIS (barra 20 $\mu \mathrm{m}$ ). 1C hepatócito apresentando cario e citomegalia indicado pela seta, grupo CIS-SW (barra 20 $\mu \mathrm{m}$ ). 1D figuras de mitoses atípicas indicadas pelas setas, grupo CISRAF (barra 20 $\mu \mathrm{m}$ ) 1E figuras de mitoses

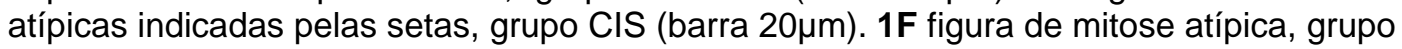

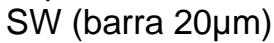




\begin{tabular}{|c|c|}
\hline Grupos & Descrição histopatológica de tecido renal \\
\hline Branco & $\begin{array}{l}\text { Preservação da arquitetura histológica e glomérulos livres } \\
\text { de processos patológicos. }\end{array}$ \\
\hline Controle & $\begin{array}{l}\text { Preservação da arquitetura histológica e glomérulos livres } \\
\text { de processos patológicos; } \\
\text { Presença de células neoplásicas aderidas na cápsula } \\
\text { renal. }\end{array}$ \\
\hline $\begin{array}{c}\text { CIS } \\
(0,25 \mathrm{mg} / \mathrm{kg})\end{array}$ & $\begin{array}{l}\text { Preservação da arquitetura histológica e glomérulos livres } \\
\text { de processos patológicos; } \\
\text { Presença de proteinúria em túbulos proximais. } \\
\text { Alguns animais apresentaram células neoplásicas em torno } \\
\text { da cápsula hepática, associado a infiltrado polimorfonuclear. }\end{array}$ \\
\hline CIS-SW & $\begin{array}{l}\text { Preservação da arquitetura histológica; } \\
\text { Discreto quadro de glomerulonefrite membranoproliferativa } \\
\text { multifocal segmentar; } \\
>\text { Presença de discreta proteinúria em túbulos proximais. } \\
>\text { Alguns animais apresentaram células neoplásicas em torno } \\
\text { da cápsula renal }\end{array}$ \\
\hline sw & $\begin{array}{l}\text { Preservação da arquitetura histológica. } \\
\text { Alguns animais apresentaram células neoplásicas em torno } \\
\text { da cápsula renal }\end{array}$ \\
\hline CIS-RAF & $\begin{array}{l}\text { Preservação da arquitetura histológica; } \\
>\text { Presença de discreta proteinúria em túbulos proximais. } \\
\text { Alguns animais apresentaram células neoplásicas em torno } \\
\text { da cápsula renal. }\end{array}$ \\
\hline RAF & $\begin{array}{l}>\text { Preservação da arquitetura histológica; } \\
>\text { Discreto espessamento de membrana basal. }\end{array}$ \\
\hline
\end{tabular}

Quadro 9: Descrição histopatológica de tecido renal de camundongos C57BL/6 inoculados com o tumor ascítico de Ehrlich e submetidos a diferentes tratamentos: branco (não inoculado); controle; $\mathrm{Cis}=$ tratado com cisplatina; $\mathrm{CIS}-\mathrm{SW}=$ tratado com cisplatina e swainsonina; SW = tratado com suainsonina; CIS-RAF = tratado com cisplatina e fração aquosa de Ipomoea carnea; RAF = tratado com fração aquosa de l. carnea 


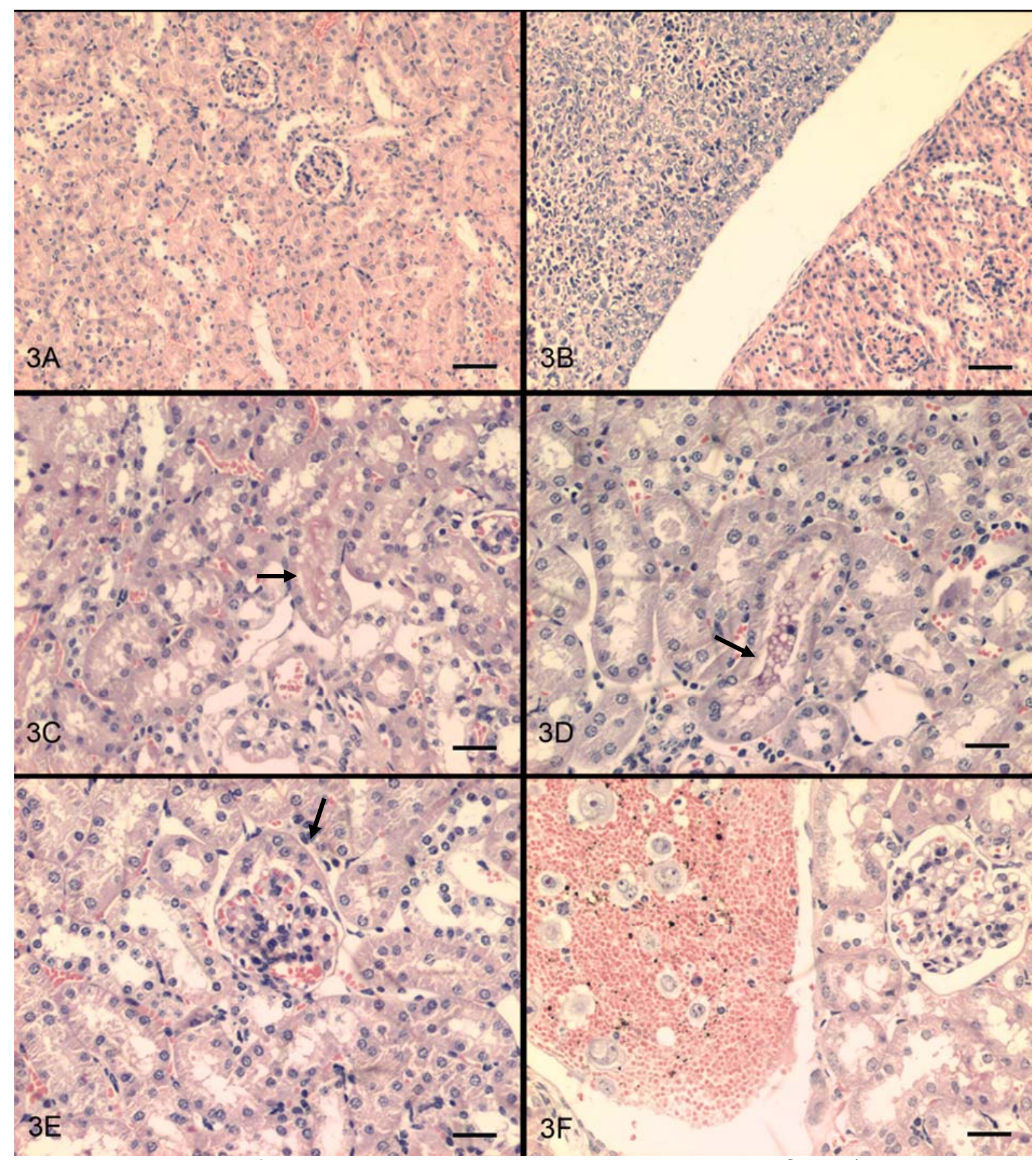

Figura 44: Fotomicrografias dos principais achados renais de camundongos C57BL/6 inoculados com o tumor ascítico de Ehrlich e submetidos a diferentes tratamentos: branco (não inoculado); controle; Cis = tratado com cisplatina; CIS-SW = tratado com cisplatina e swainsonina; SW = tratado com suainsonina; CIS-RAF = tratado com cisplatina e fração aquosa de Ipomoea carnea; RAF = tratado com fração aquosa de I. carnea. 3A características histológicas normais, grupo branco (barra 20 $\mu \mathrm{m}$ ). 3B células neoplásicas aderidas à cápsula renal, grupo controle (barra $40 \mu \mathrm{m})$. 3C presença de proteinúria em túbulos proximais indicada pela seta, grupo CIS-SW (barra 20 $\mu \mathrm{m}$ ). 3D presença de proteinúria em túbulos proximais indicada pela seta, grupo CIS (barra 20 $\mu \mathrm{m}$ ) 3E espessamento da cápsula de Bowman indicado pela seta, grupo CIS-SW (barra 20 $\mu m$ ). 3F presença de células neoplásicas no interior de vaso renal, grupo CIS (barra 20 $\mu \mathrm{m}$ ) 


\begin{tabular}{|c|c|}
\hline Grupos & Descrição histopatológica de tecido esplênico \\
\hline Branco & $\begin{array}{l}>\text { Quadro histológico dentro dos limites da normalidade; } \\
>\text { Raros megacariócitos. }\end{array}$ \\
\hline Controle & $\begin{array}{l}\text { Quadro histológico dentro dos limites da normalidade; } \\
>\text { Discreta hemossiderose. } \\
>\text { Raros megacariócitos. } \\
>\text { Presença de células neoplásicas aderidas na cápsula } \\
\text { esplênica. }\end{array}$ \\
\hline $\begin{array}{c}\text { CIS } \\
(0,25 \mathrm{mg} / \mathrm{kg})\end{array}$ & $\begin{array}{l}\text { Hemossiderose, variando de discreta à moderada; } \\
\text { Presença de discreto a moderado megacariócitos. }\end{array}$ \\
\hline CIS-SW & $\begin{array}{l}\text { Discreta hemossiderose; } \\
\text { Presença de discretos a moderado número de mega- } \\
\text { cariócitos. } \\
\text { Alguns animais apresentaram células neoplásicas na } \\
\text { cápsula esplênica. }\end{array}$ \\
\hline SW & $\begin{array}{l}\text { Observou-se discreta hemossiderose; } \\
\text { Presença de discreto a moderado número de mega- } \\
\text { cariócitos. } \\
\text { Alguns animais apresentaram células neoplásicas na } \\
\text { cápsula esplênica. }\end{array}$ \\
\hline CIS-RAF & $\begin{array}{l}\text { Presença de discreto a moderado número de mega- } \\
\text { cariócitos. } \\
\text { Alguns animais apresentaram células neoplásicas na } \\
\text { cápsula esplênica }\end{array}$ \\
\hline RAF & $\begin{array}{l}\text { Discreta hemossiderose; } \\
>\text { Presença de discreto número de megacariócitos. }\end{array}$ \\
\hline
\end{tabular}

Quadro 10: Descrição histopatológica de tecido esplênico de camundongos C57BL/6 inoculados com o tumor ascítico de Ehrlich e submetidos a diferentes tratamentos: branco (não inoculado); controle; Cis = tratado com cisplatina; CIS-SW = tratado com cisplatina e swainsonina; SW = tratado com suainsonina; CIS-RAF = tratado com cisplatina e fração aquosa de Ipomoea carnea; RAF = tratado com fração aquosa de $I$. carnea 


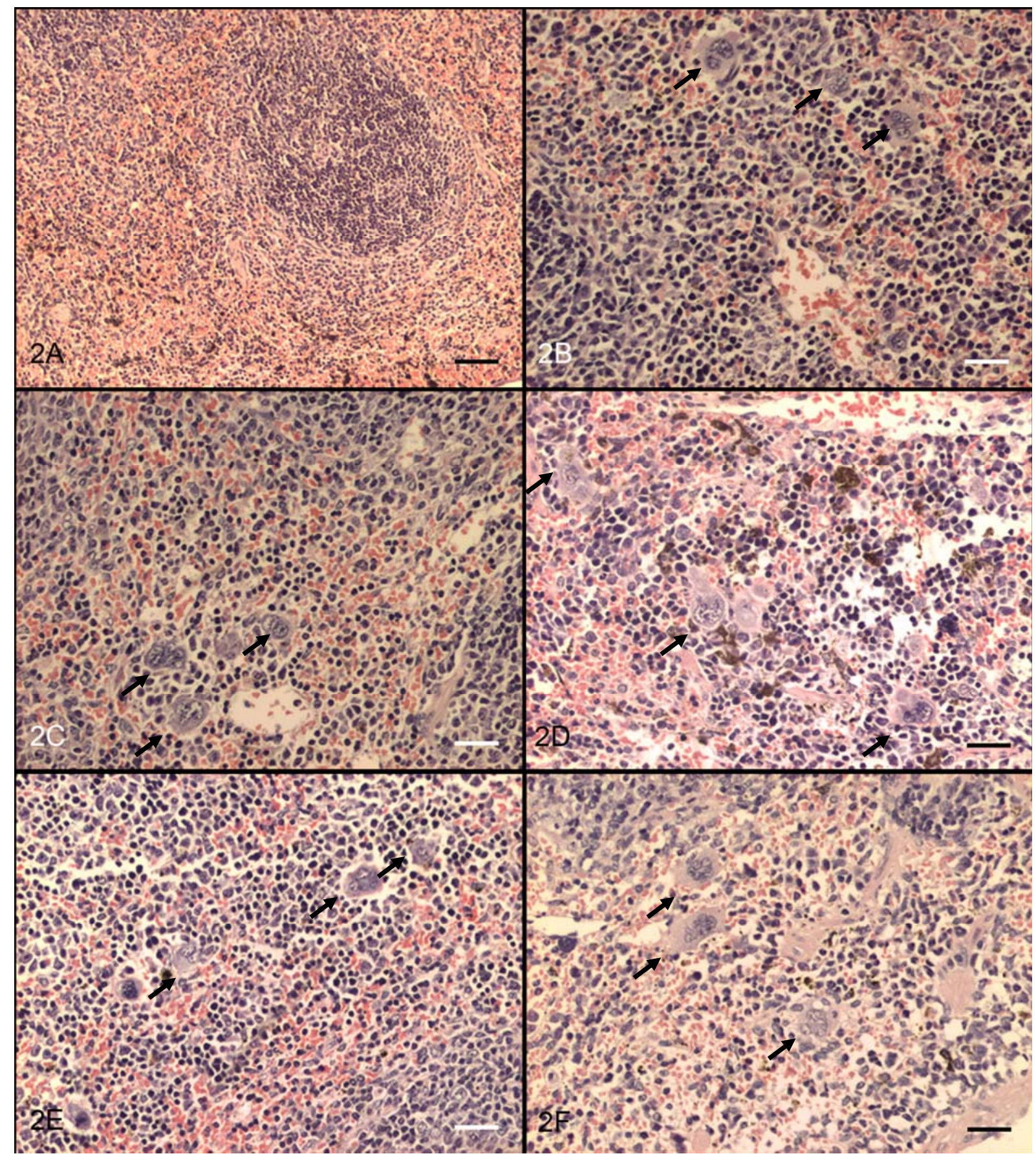

Figura 45: Fotomicrografias dos principais achados esplênicos de camundongos C57BL/6 inoculados com o tumor ascítico de Ehrlich e submetidos a diferentes tratamentos: branco (não inoculado); controle; Cis = tratado com cisplatina; CIS-SW = tratado com cisplatina e swainsonina; SW = tratado com suainsonina; CIS-RAF = tratado com cisplatina e fração aquosa de Ipomoea carnea; RAF = tratado com fração aquosa de I. carnea. 2A características histológicas normais com discreta hemossiderose, grupo branco (barra $100 \mu \mathrm{m})$. 2B megacariócitos indicados pelas setas, grupo controle (barra 20 $\mu \mathrm{m})$. 2C megacariócitos indicados pelas setas, grupo CIS (barra 20 $\mu \mathrm{m}$ ). 2D discreta hemossiderose e megacariócitos indicados pelas setas, grupo CIS (barra 20 $\mu \mathrm{m}$ ) 2E megacariócitos indicados pelas setas, grupo CIS-SW (barra 20 $\mu \mathrm{m}$ ). 2F megacariócitos indicados pelas setas, grupo SW (barra 20 $\mu \mathrm{m}$ ) 
4.7 Experimento 7: Avaliação da celularidade da medula óssea esplênica de camundongos C57BI/6 inoculados com tumor ascítico de Ehrlich tratados com suainsonina administrando, concomitantemente ou não, a dose de 5mg/kg de cisplatina

4.7.1 Teste preliminar: avaliação de celularidade da medula óssea de diferentes linhagens de camundongos

Em relação à celularidade total da medula óssea de camundongos de diferentes linhagens (Balb-c; Swiss, e C57BL/6), não houve diferenças estatísticas entre os grupos estudados (ANOVA, $F=1,073 ; d f=2 / 28 ; p=0,3557$ Tabela 15 e Figura 46).

Tabela 15: Celularidade de medula óssea de camundongos de diferentes linhagens

\begin{tabular}{|cccc|}
\hline & $\begin{array}{c}\text { Balb-c } \\
(\mathbf{n}=\mathbf{9})\end{array}$ & $\begin{array}{c}\text { Swiss } \\
(\mathbf{n}=\mathbf{1 2})\end{array}$ & $\begin{array}{c}\text { C57BI/6 } \\
(\mathbf{n}=\mathbf{1 0})\end{array}$ \\
\hline Número total de células da & 53,61 & 56,04 & 52,75 \\
medula óssea $\left(\mathbf{1 0}^{\mathbf{6}}\right)$ & $\pm 1,77$ & $\pm 1,58$ & $\pm 1,80$ \\
\hline
\end{tabular}

São apresentadas as médias e os respectivos erros padrões (ANOVA - $p<0,05)$. 


\section{Contagem total \\ de células medulares}

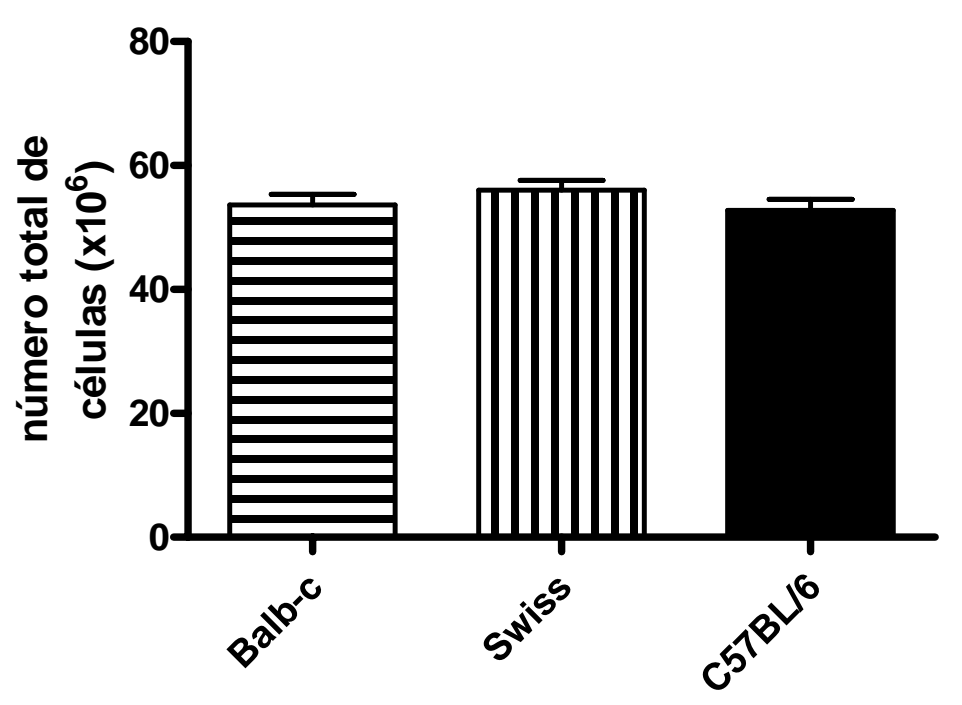

Figura 46: Celularidade de medula óssea de camundongos das linhagens Balb-c; Swiss e C57BL/6. $O$ traço horizontal indica a média do número de células ( $n=9-12$ por grupo). São apresentadas as medias e os respectivos erros padrões. (ANOVA, $p>0,05$ )

4.7.2 Avaliação da celularidade da medula óssea e esplênica de camundongos C57BI/6 inoculados com tumor ascítico de Ehrlich tratados com suainsonina administrando, concomitantemente, ou não, a dose de $5 \mathrm{mg} / \mathrm{kg}$ de cisplatina

\subsubsection{Crescimento tumoral (volume e celularidade):}

Apenas os animais dos grupos controle e do grupo tratado com a suainsonina (Sw) desenvolveram o tumor ascítico de Ehrlich; vale ressaltar que os animais do grupo Branco não foram inoculados com o tumor.

Após a retirada do tumor ascítico de Ehrlich dos animais, foi mensurado o volume tumoral obtido, sendo observado que os animais dos grupos Cis e CisSW não desenvolveram o tumor, e, portanto, quando foram comparados com os 
animais do grupo controle apresentaram uma redução significativa do volume tumoral (ANOVA - F=272,1; df=3/25; $\mathrm{p}<0,0001$ - pós teste de Dunnett's $p<0,001)$ - Tabela 16 e Figura 47.

Em relação à celulariedade tumoral, foi avaliada tanto a quantidade de células tumorais $/ \mathrm{mL}$ da amostra, como a celularidade tumoral total. Na contagem de células tumorais $/ \mathrm{mL}$ de cada amostra, foi possível observar redução significante deste parâmetro nos animais do grupo Cis e CisSW, quando comparados àqueles do grupo controle (ANOVA - $F=59,78$; $d f=3 / 25 ; p<0,0001$ pós teste de Dunnett's - $p<0,001)$ - Tabela 16 e Figura 48.

Em relação à celularidade tumoral total, observou-se diminuição do número total de células tumorais em animais dos grupos Cis e CisSW (ambos com valores de $p<0,001)$, quando comparados aos animais pertencentes ao grupo controle (ANOVA - F=58,85; df=3/25; $p<0,0001$ - pós teste de Dunnett's $p<0,001)$ - Tabela 16 e Figura 49. 


\section{RESULTADOS}

Tabela 16: Volume tumoral, número de células tumorais/mL, número total de células tumorais e peso esplênico relativo de camundongos C57BL/6 inoculados com tumor ascítico de Ehrlich e submetidos a diferentes tratamentos: branco (não inoculado); controle; Cis = tratado com $5 \mathrm{mg} / \mathrm{kg}$ de cisplatina; $\mathrm{CIS}-\mathrm{SW}=$ tratado com cisplatina e suainsonina; $\mathrm{SW}=$ tratado com suainsonina

\begin{tabular}{|c|c|c|c|c|c|}
\hline (2) & $\begin{array}{c}\mathrm{Br} \\
(\mathrm{n}=6)\end{array}$ & $\begin{array}{c}\text { Co } \\
(n=8)\end{array}$ & $\begin{array}{c}\text { Cis } \\
(n=8)\end{array}$ & $\begin{array}{c}\text { CisSW } \\
(n=8)\end{array}$ & $\begin{array}{c}\text { Sw } \\
(n=5)\end{array}$ \\
\hline $\begin{array}{c}\text { Volume } \\
\text { Tumoral (mL) }\end{array}$ & & $\begin{array}{r}14,35 \\
\pm 0,87\end{array}$ & $\begin{array}{c}0,0 \\
\pm 0,0 * * *\end{array}$ & $\begin{array}{c}0,0 \\
\pm 0,0^{* * *}\end{array}$ & $\begin{array}{r}13,80 \\
\pm 0,24\end{array}$ \\
\hline Número de células tumorais por $\mathrm{mL}\left(\times 10^{7}\right)$ & & $\begin{array}{r}13,22 \\
\pm 1,34\end{array}$ & $\begin{array}{c}0,0 \\
\pm 0,0 * \star \star\end{array}$ & $\begin{array}{c}0,0 \\
\pm 0,0 \star \star \star\end{array}$ & $\begin{array}{l}11,40 \\
\pm 1,70\end{array}$ \\
\hline Número total de células tumorais $\left(\times 10^{8}\right)$ & & $\begin{array}{r}18,87 \\
\pm 1,99\end{array}$ & $\begin{array}{c}0,0 \\
\pm 0,0 * * \star\end{array}$ & $\begin{array}{c}0,0 \\
\pm 0,0^{\star \star \star}\end{array}$ & $\begin{array}{l}15,65 \\
\pm 2,21\end{array}$ \\
\hline Peso Esplênico relativo (\%) & $\begin{array}{r}0,2940 \\
\pm 0,0097\end{array}$ & $\begin{array}{c}0,2422 \\
\pm 0,0183\end{array}$ & $\begin{array}{c}0,1967 \\
\pm 0,0130^{\#}\end{array}$ & $\begin{array}{r}0,2138 \\
\pm 0,0274\end{array}$ & $\begin{array}{r}0,2267 \\
\pm 0,0208\end{array}$ \\
\hline
\end{tabular}

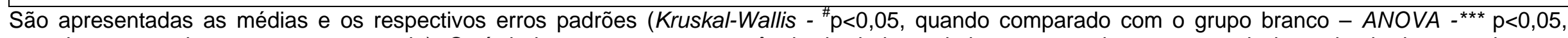
quando comparado com o grupo controle). O símbolo representa a ausência de dados, relativos ao crescimento tumoral, dos animais do grupo branco, uma vez que estes não foram inoculados com o tumor ascítico de Ehrlich. 


\section{Volume tumoral}

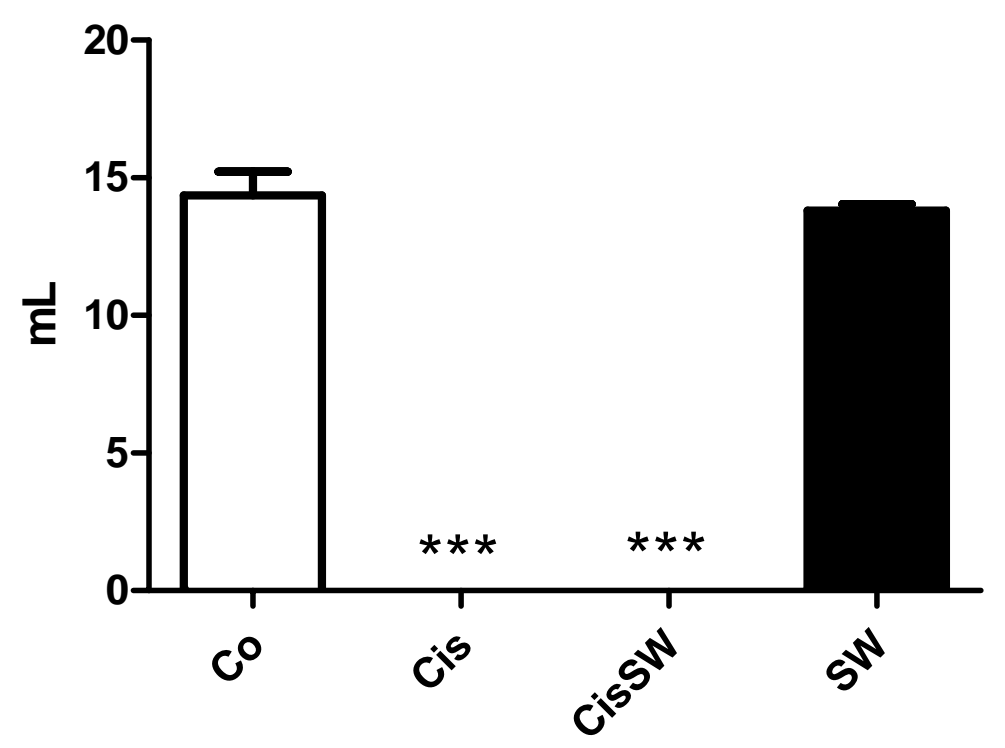

Figura 47: Volume tumoral de camundongos C57BL/6 inoculados com tumor ascítico de Ehrlich e submetidos a diferentes tratamentos: controle; Cis = tratado com $5 \mathrm{mg} / \mathrm{kg}$ de cisplatina; CIS-SW = tratado com cisplatina e suainsonina; SW = tratado com suainsonina. São apresentadas as medias e os respectivos erros padrões ( $n=5-8$ por grupo). (ANOVA pós teste de Dunnett's - ***p>0,05, quando comparado com o grupo controle)

\section{Número de células tumorais por $\mathrm{mL}$}

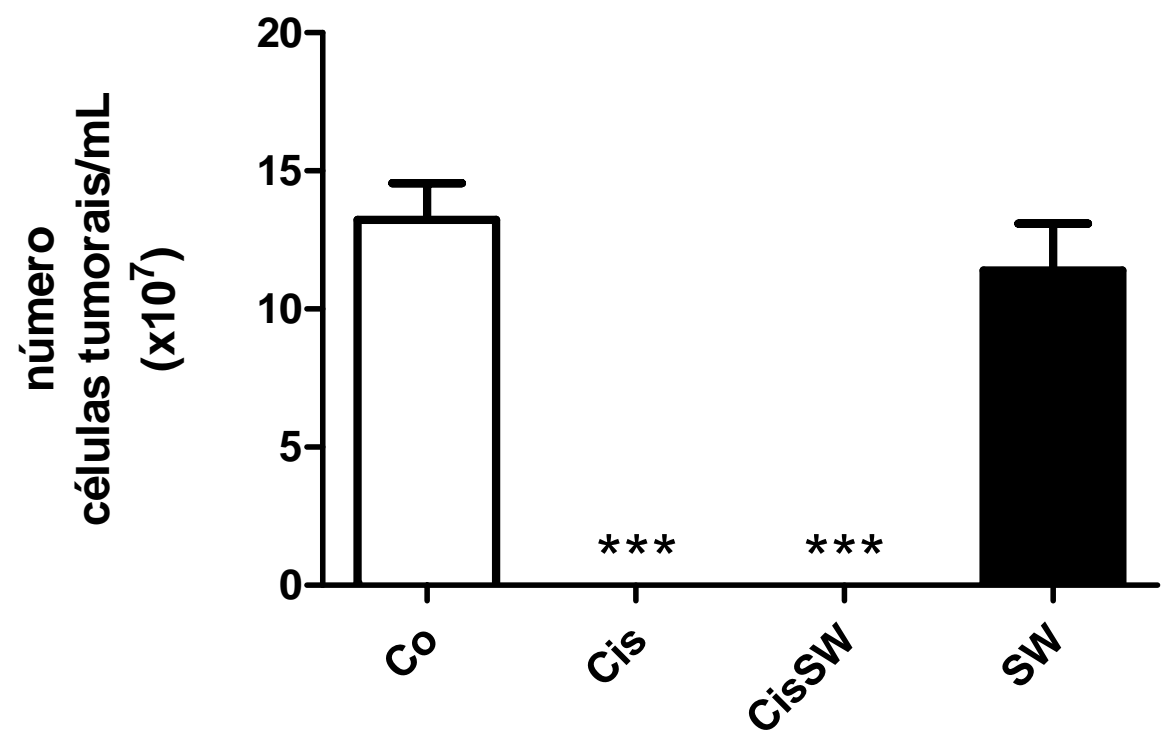

Figura 48: Número de células tumorais/mL de camundongos C57BL/6 inoculados com tumor ascítico de Ehrlich e submetidos a diferentes tratamentos: controle; Cis = tratado com $5 \mathrm{mg} / \mathrm{kg}$ de cisplatina; CIS-SW = tratado com cisplatina e suainsonina; $\mathrm{SW}=$ tratado com suainsonina. São apresentadas as medias e os respectivos erros padrões $(n=5-8$ por grupo). (ANOVA - pós teste de Dunnett's - *** $>0,05$, quando comparado com o grupo controle) 


\section{Número total de células tumorais de Ehrlich}

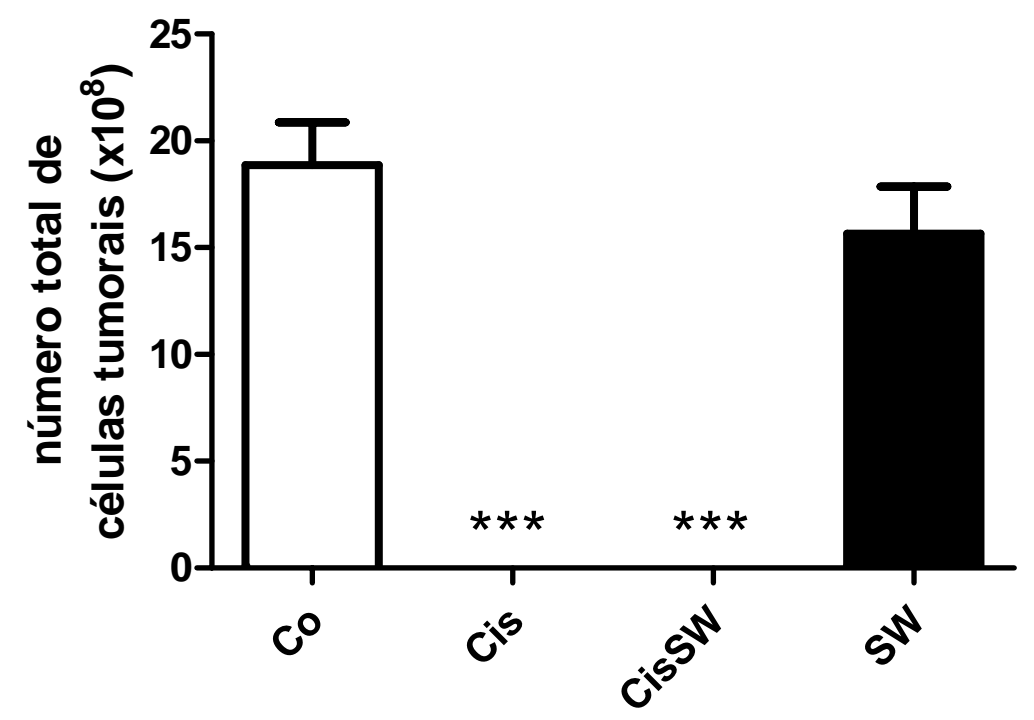

Figura 49: Número de células tumorais/mL de camundongos C57BL/6 inoculados com tumor ascítico de Ehrlich e submetidos a diferentes tratamentos: controle; Cis $=$ tratado com $5 \mathrm{mg} / \mathrm{kg}$ de cisplatina; CIS-SW = tratado com cisplatina e suainsonina; $\mathrm{SW}=$ tratado com suainsonina. São apresentadas as medias e os respectivos erros padrões $(n=5-8$ por grupo). (ANOVA, pós teste de Dunnett's - ${ }^{* \star} p>0,05$, quando comparado com o grupo controle)

4.7.2.2 Avaliação esplênica e da celularidade da medula óssea

Em relação à avaliação esplênica dos animais foi possível notar uma diminuição estatisticamente significante no peso relativo deste órgão nos animias pertencentes ao grupo tratado com cisplatina (Cis), quando comparado aos animais do grupo branco (Kruskal-Wallis - KW=10,96; $\mathrm{p}=0,0270$ - pós teste de Dunn's - $p<0,05$ ), ou seja, animais que não receberam qualquer tratamento (nem foram inoculados com o tumor ascítico de Ehrlich). Estes dados podem ser observados na tabela 17 e na figura 51. 
A análise da celularidade esplênica total mostrou a existência de uma redução significante destes valores entre os camundongos do grupo CisSW (tratados com a associação de suainsonia e cisplatina) quando comparados aos animais do grupo controle (ANOVA - $F=3,187 ; d f=4 / 31 ; p=0,0245$ - pós teste de Dunntt's $p<0,05)$ - Tabela 17 e Figura 52. Não foi possível evidenciar qualquer outra diferença significante entre os demais grupos.

A avaliação da celularidade total da meula óssea revelou que não existiu qualquer diferença estatística entre os grupos experimetnais quando comparados aos animais do grupo controle e branco. (ANOVA - $p=0,0763$ ) - Tabela 18.

Tabela 17: Número total de células esplênicas de camundongos C57BL/6 inoculados com tumor ascítico de Ehrlich e submetidos a diferentes tratamentos: branco (não inoculado); controle; Cis = tratado com $5 \mathrm{mg} / \mathrm{kg}$ de cisplatina; CIS-SW = tratado com cisplatina e suainsonina; $\mathrm{SW}=$ tratado com suainsonina

\begin{tabular}{|c|c|c|c|c|c|}
\hline & $\begin{array}{c}\mathrm{Br} \\
(\mathrm{n}=6)\end{array}$ & $\begin{array}{c}\text { Co } \\
(n=9)\end{array}$ & $\begin{array}{c}\text { CIS } \\
(n=9)\end{array}$ & $\begin{array}{c}\text { CisSW } \\
(n=9)\end{array}$ & $\begin{array}{c}\text { SW } \\
(n=6)\end{array}$ \\
\hline $\begin{array}{c}\text { Número total de células } \\
\text { esplênicas }\left(10^{8}\right)\end{array}$ & $\begin{array}{r}137,5 \\
\pm 17,07\end{array}$ & $\begin{array}{c}143,7 \\
\pm 23,94\end{array}$ & $\begin{array}{l}105,6 \\
\pm 6,86\end{array}$ & $\begin{array}{c}78,42 \\
\pm 9,46 \text { * }\end{array}$ & $\begin{array}{r}138,2 \\
\pm 17,68\end{array}$ \\
\hline
\end{tabular}

São apresentadas as médias e os respectivos erros padrões (ANOVA - *p<0,05 pós teste de Dunnett's, quando comparado com o grupo controle).

Tabela 18: Número total de células da medula óssea de camundongos C57BL/6 inoculados com tumor ascítico de Ehrlich e submetidos a diferentes tratamentos: branco (não inoculado); controle; Cis = tratado com $5 \mathrm{mg} / \mathrm{kg}$ de cisplatina; CIS-SW = tratado com cisplatina e suainsonina; $\mathrm{SW}=$ tratado com suainsonina

\begin{tabular}{|lccccc|}
\hline & $\begin{array}{c}\mathbf{B r} \\
(\mathbf{n}=\mathbf{6})\end{array}$ & $\begin{array}{c}\text { Co } \\
(\mathbf{n}=\mathbf{9})\end{array}$ & $\begin{array}{c}\text { CIS } \\
(\mathbf{n}=\mathbf{9})\end{array}$ & $\begin{array}{c}\text { CisSW } \\
(\mathbf{n}=\mathbf{8})\end{array}$ & $\begin{array}{c}\text { SW } \\
(\mathbf{n}=5)\end{array}$ \\
\hline Número total de células & 56,83 & 46,67 & 52,75 & 44,91 & 49,10 \\
da medula óssea $\left(\mathbf{1 0}^{\mathbf{6}}\right)$ & $\pm 3,62$ & $\pm 3,04$ & $\pm 2,45$ & $\pm 2,68$ & $\pm 6,41$ \\
\hline
\end{tabular}

São apresentadas as médias e os respectivos erros padrões (ANOVA - $p>0,05$ ). 


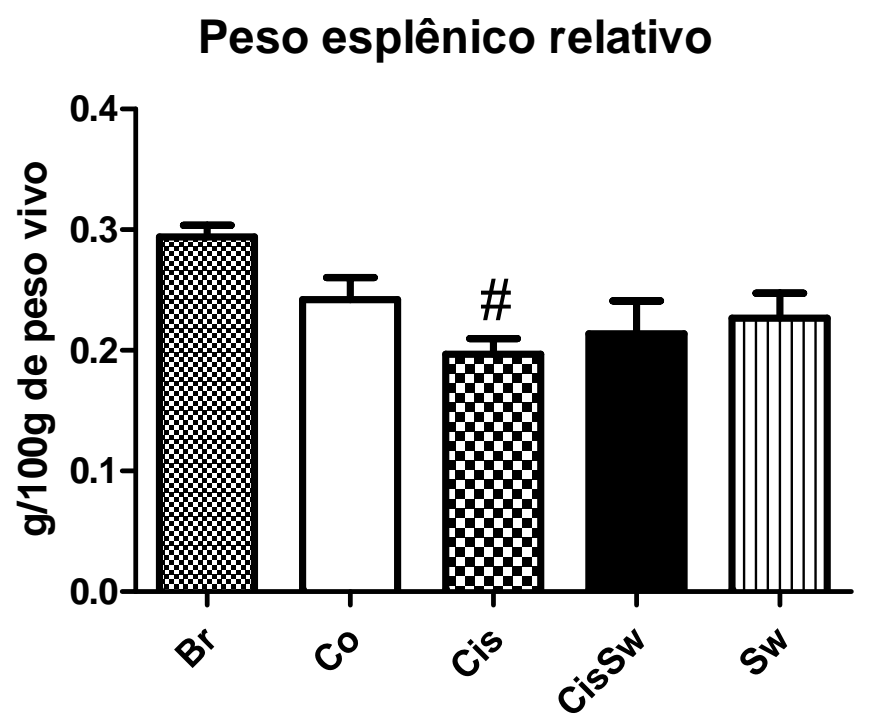

Figura 50: Peso esplênico relativo de camundongos C57BL/6 inoculados com tumor ascítico de Ehrlich e submetidos a diferentes tratamentos: controle; Cis $=$ tratado com $5 \mathrm{mg} / \mathrm{kg}$ de cisplatina; CIS-SW = tratado com cisplatina e suainsonina; $\mathrm{SW}=$ tratado com suainsonina. São apresentadas as medias e os respectivos erros padrões ( $n=5-8$ por grupo). (Kruskal-Wallis - pós teste de Dunn's - \#p>0,05, quando comparado com o grupo branco)

\section{Número total de células Esplênicas}

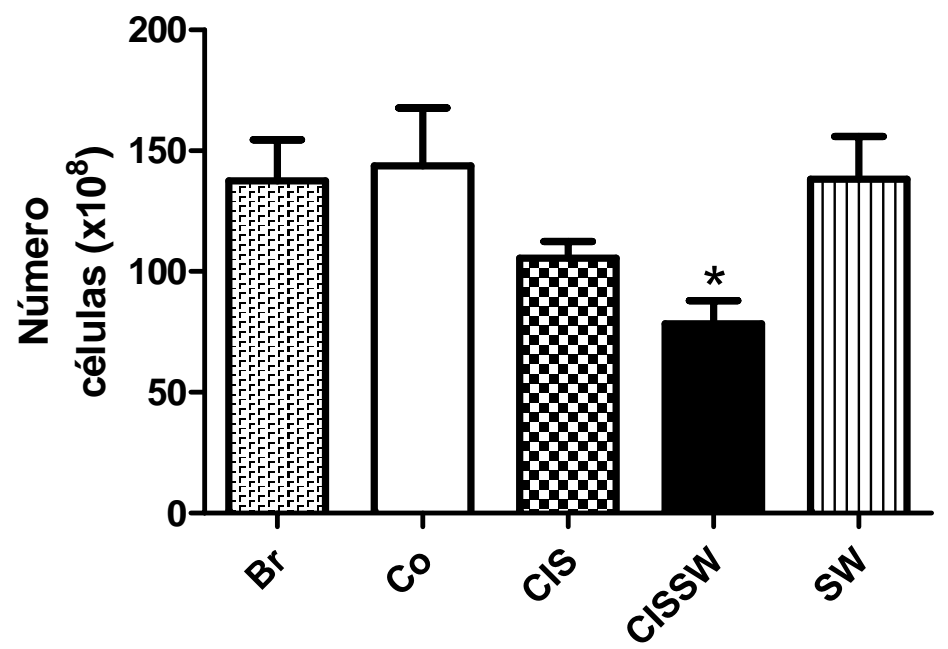

Figura 51: Número total de céluas esplênicas de camundongos C57BL/6 inoculados com tumor ascítico de Ehrlich e submetidos a diferentes tratamentos: controle; Cis = tratado com $5 \mathrm{mg} / \mathrm{kg}$ de cisplatina; CIS-SW = tratado com cisplatina e suainsonina; SW = tratado com suainsonina. São apresentadas as medias e os respectivos erros padrões $(n=5-8$ por grupo). (ANOVA - pós teste de Dunnett's - *p $>0,05$, quando comparado com o grupo controle) 


\subsubsection{Avaliação histopatológica}

O quadro 11 apresenta a compilação dos principais achados histopatológicos do tecido hepático dos grupos branco, controle e dos diferentes grupos experimentais ( $\mathrm{CIS}$, CisSW e SW). Os animais do grupo branco apresentaram um discreto número de hepatócitos binucleados e relações histopatológicas dentro dos padrões da normalidade. O mesmo foi observado nos animais do grupo controle, porém em alguns cortes foi possível observar a presença de células neoplásicas na cápsula hepática, em alguns casos foi evidenciada a existência de êmbolos neoplásicos nos vasos do sistema porta.

Nos animias pertencentes aos grupos tratados com cisplatina (CIS e CisSW), na dose de $5 \mathrm{mg} / \mathrm{kg}$, foi observado aumento no número de células hepáticas binucleadas, e no número de mitoses, muitas destas mitoses eram atípicas.

Nos animais do grupo SW (tratado apenas com a suainsonina) foi observado um quadro histológico semelhante ao do grupo branco, discreto número de hepatócitos binucleados e relações histopatológicas dentro dos padrões da normalidade, porém em algumas lâminas foram observadas céluas neoplásicas aderidas na cápsula hepática.

Os principais achados histopatológicos renais dos grupos: branco, controle e grupos experimentais (Cis, CisSW e SW) estão expostos no quadro 12. Os animais do grupo Cis apresentaram discreto espessamento da membrana basal e discreta proteinúria. Em alguns cortes histopatológicos foram observados 
aumento na cápsula de Bowman, associado a infiltrados de céluas mononuclerares.

Os demais grupos (branco, controle, CisW e SW) apresentaram quadros histológicos dentro da normalidade, com preservação da arquitetura do parênquima renal. Vale frisar que alguns animais do grupo controle e SW possuíam células neoplásicas aderidas na cápsula renal.

A análise do material histopatológico esplênico, compilada no quadro 13, mostrou que os camundongos do grupo branco apresentaram um quadro histológico dentro dos padrões de normalidade, com a presença de raros megacariócitos no parênquima do órgão. Estes achados também foram observados nos animais do grupo controle (inoculados com o tumor ascítico de Ehrlich) e CIS, porém observou-se nestes animais uma discreta hemossiderose. Em alguns dos animais pertencentes ao grupo controle foi observada a existência de células neoplásicas em torno da cápsula do baço.

Os animais do grupo CisSW apresentaram hemossiderose, variando de discreta a moderada, em algumas lâminas foi observado um discreto aumento de linfocitólise nos centros germinativos da polpa branca. Os animais do grupo SW apresentaram discreta hemossiderose, e em algumas lâminas foi observado um discreto aumento de linfocitólise nos centros germinativos da polpa branca, outras lâminas apresentaram células neoplásicas aderidas em torno da cápsula do órgão. Além disso, um camundongo deste grupo apresentou uma discreta presença de fibrose, atrofia e necrose do parênquima esplênico.

Os achados histológicos mais relevantes dos diferentes órgãos estão expostos na figura 52. 


\begin{tabular}{|c|c|}
\hline Grupos & Descrição histopatológica de tecido hepático \\
\hline Branco & $\begin{array}{l}\text { Poliploidia, observada pela presença de discretos hepatócitos } \\
\text { binucleados; } \\
>\text { Demais relações histológicas preservadas. }\end{array}$ \\
\hline Controle & $\begin{array}{l}\text { Observações histológicas semelhantes as do grupo branco. } \\
\text { Alguns animais apresentaram focos neutrofílicos, presença de } \\
\text { células neoplásicas na cápsula hepática e êmpulos neoplásicos } \\
\text { em vasos. }\end{array}$ \\
\hline $\begin{array}{c}\text { CIS } \\
(5 \mathrm{mg} / \mathrm{kg})\end{array}$ & $\begin{array}{l}\text { Poliploidia, observada por discreto aumento de hepatócitos } \\
\text { binucleados; } \\
>\text { Aumento do número de mitoses evidentes, algumas mitoses } \\
\text { atípicas; } \\
>\text { Demais relações histológicas semelhantes ao grupo branco. }\end{array}$ \\
\hline CIS-SW & $\begin{array}{l}\text { Poliploidia, observada por discreto aumento de hepatócitos } \\
\text { binucleados; } \\
\text { Aumento do número de mitoses evidentes, algumas mitoses } \\
\text { atípicas; } \\
>\text { Demais relações histológicas semelhantes ao grupo branco. }\end{array}$ \\
\hline SW & $\begin{array}{l}\text { Poliploidia observada por: discretos hepatócitos binucleados; } \\
\text { > Presença de células neoplásicas na cápsula hepática; } \\
\text { > Demais relações histológicas semelhantes ao grupo branco. }\end{array}$ \\
\hline
\end{tabular}

Quadro 11: Descrição histopatológica de tecido hepático de camundongos C57BL/6 inoculados com o tumor ascítico de Ehrlich e submetidos a diferentes tratamentos: branco (não inoculado); controle; Cis = tratado com cisplatina; CIS-SW = tratado com cisplatina e swainsonina; SW $=$ tratado com swainsonina 


\begin{tabular}{|cc|}
\hline Grupos & Descrição histopatológica de tecido renal \\
\hline Branco & $>$ Preservação da arquitetura histológica. \\
\hline Controle & $>$ Preservação da arquitetura histológica; \\
& $>$ Tumor aderido à superfície renal. \\
\hline CIS & $>$ Preservação da arquitetura histológica; \\
$(5 \mathbf{m g} / \mathbf{k g})$ & $>$ Discreto espessamento de membrana basal; \\
& $>$ associado com infiltrado mononuclear. \\
\hline CIS-SW & $>$ Preservação da arquitetura histológica. \\
\hline SW & $>$ Preservação da arquitetura histológica. \\
\hline
\end{tabular}

Quadro 12: Descrição histopatológica de tecido renal de camundongos C57BL/6 inoculados com o tumor ascítico de Ehrlich e submetidos a diferentes tratamentos: branco (não inoculado); controle; Cis = tratado com cisplatina; CIS-SW = tratado com cisplatina e swainsonina; $\mathrm{SW}=$ tratado com swainsonina 


\begin{tabular}{|ll|}
\hline Grupos & Descrição histopatológica de tecido esplênico \\
\hline Branco & $>$ Preservação da arquitetura histológica \\
& $>$ Presença de discreto número de megacariócitos. \\
\hline Controle & $>$ Discreta hemossiderose; \\
& $>$ Discreto a moderado número de megacariócitos. \\
\hline CIS & $>$ Discreta a moderada hemossiderose; \\
$\mathbf{( 5 m g / k g ) ~}$ & $>$ Presença de discreto número de megacariócitos \\
\hline & $>$ Discreta a moderada hemossiderose; \\
CIS-sw & $>$ Discreto aumento de linfocitólise em centro germinativo da polpa \\
& $>$ branca. \\
& $>$ Presença de discreto número de megacariócitos \\
& $>$ Discreto aumento de linfocitólise em centro germinativo da polpa \\
& branca; \\
& $>$ Discreta hemossiderose. \\
& $>$ Um animal apresentou discreta presença de fibrose, atrofia e \\
& necrose do parênquima.
\end{tabular}

Quadro 13: Descrição histopatológica de tecido esplênico de camundongos C57BL/6 inoculados com o tumor ascítico de Ehrlich e submetidos a diferentes tratamentos: branco (não inoculado); controle; Cis = tratado com cisplatina; $\mathrm{CIS}-\mathrm{SW}=$ tratado com cisplatina e swainsonina; SW = tratado com suainsonina 


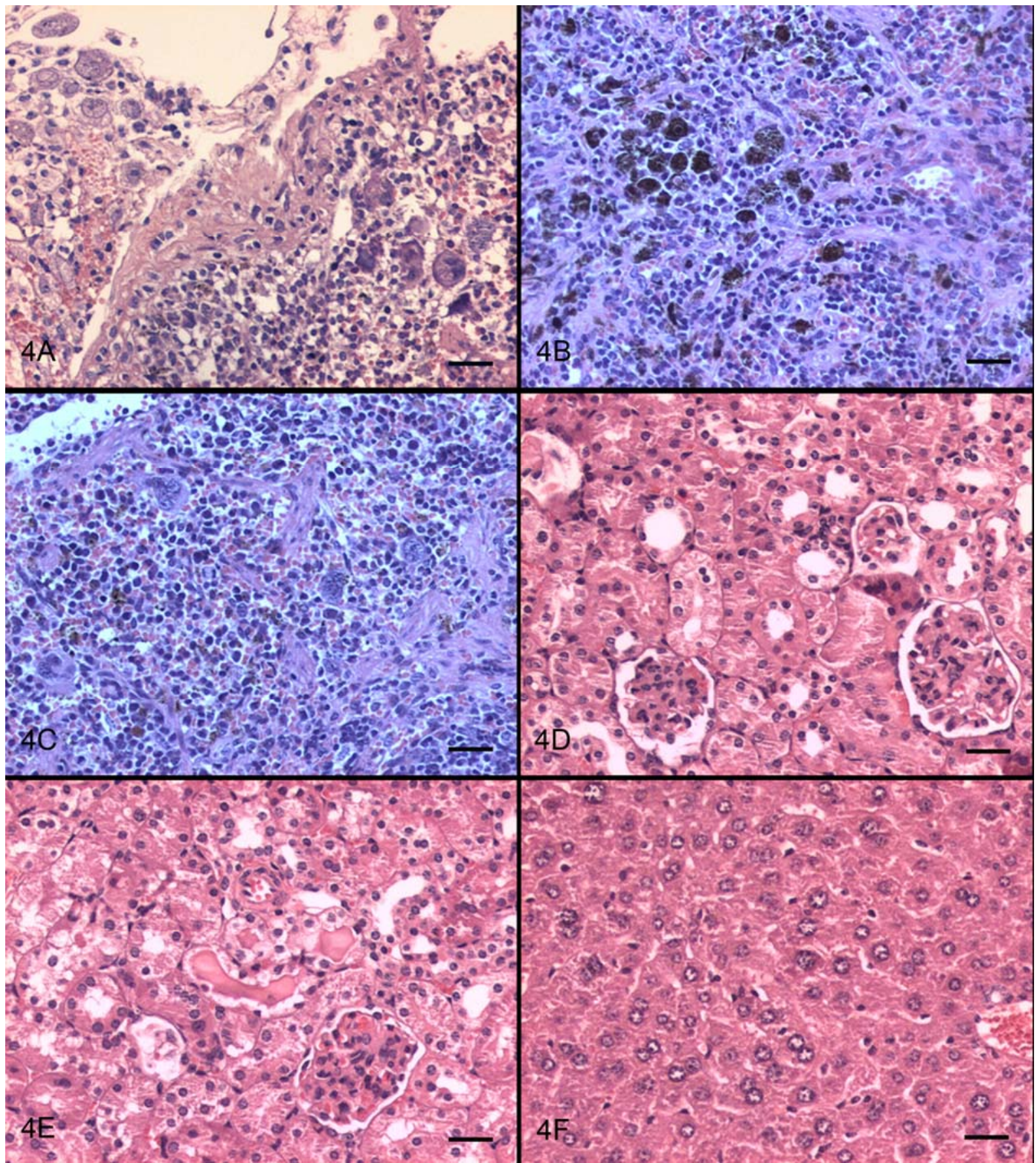

Figura 52: Fotomicrografias dos principais achados de camundongos C57BL/6 inoculados com o tumor ascítico de Ehrlich e submetidos a diferentes tratamentos: branco (não inoculado); controle; Cis = tratado com cisplatina; CIS-SW = tratado com cisplatina e swainsonina; $\mathrm{SW}=$ tratado com swainsonina. 4A tecido esplênico apresentando invasão de células

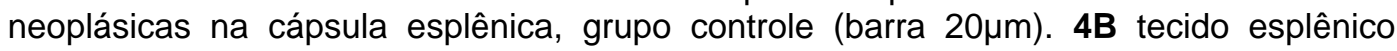
apresentando discreta hemossiderose e megacariócitos, grupo CIS (barra 20 $\mu \mathrm{m}$ ). 4C tecido esplênico apresentando megacariócitos, grupo SW (barra 20 $\mu \mathrm{m}$ ). 4D discreto

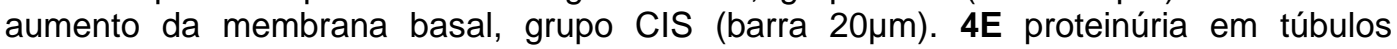
proximais, grupo CIS (barra $20 \mu \mathrm{m}$ ). $4 \mathbf{F}$ tecido hepático apresentando aumento no número de hepatócitos binucleados, grupo CIS (barra 20 $\mu \mathrm{m}$ ) 
DISCUSSÃO 


\section{DISCUSSÃO}

No presente trabalho, inicialmente, procurou-se estabelecer as condições laboratoriais mais adequadas para a inoculação e manutenção de um modelo tumoral adaptado aos objetivos propostos.

Em nossos laboratórios, a forma ascítica do tumor de Ehrlich é perpetuada por meio do transplante das células tumorais entre camundongos da linhagem Balb-c. Para a utilização destas células neoplásicas em camundongos de outras linhagens, é necessário que estas sejam transferidas para a linhagem desejada e perpetuadas nos camundongos para adquiririrem as características inerentes à linhagem de estudo. Assim, foi estabelecido em nossos laboratórios que o repique das células de Ehrlich por 12 vezes na linhagem de escolha seria suficiente para empregá-las experimentalmente.

Após a adaptação das células tumorais de Ehrlich em camundongos C57BL/6 e sabendo que estas células, quando inoculadas na musculatura, desenvolvem um tumor sólido (GUERRA, 1983), optou-se pela avaliação deste modelo, para posteriormente analisar os possíveis efeitos antineoplásicos e mieloprotetores da l. carnea e da suainsonina. Além disso, procurou-se avaliar qual dose de cisplatina deveria ser utilizada nos experimentos (Experimento 1).

Os resultados obtidos no Experimento 1 mostraram que tanto o tumor sólido de Ehrlich como as doses de cisplatina administradas não 
foram adequadas para os objetivos aqui propostos. De fato, foi observado que o tumor sólido de Ehrlich apresenta alguns aspectos negativos, como grande invasão do tecido adjacente (que dificulta a delimitação exata da margem do tumor e a retirada e mensuração da massa tumoral) e dificuldade de quantificação da viabilidade das células tumorais. Verçosa Junior et al. (2007), também relataram dificuldades na mensuração da massa neoplásica do tumor sólido de Ehrlich. Ainda, deve-se acrescentar que são necessários estudos morfométricos nas lâminas histopatológicas para conseguir diferenciar o crescimento tumoral de forma efetiva.

Optou-se pelo emprego da cisplatina como agente antineoplásico, devido ao fato desta possuir sabido efeito antitumoral (SRIGANTH; PREMALATHA, 1999) e, além disso, apresentar como um de seus efeitos adversos a mielossupressão (OGILVIE, 1998; GENTILE et al., 2001; McKNIGHT, 2003). Este último poderia ser útil para avaliar os efeitos mieloprotetores da suainsonina ou do resíduo aquoso final (RAF) da $l$. carnea nos camundongos.

Em relação às doses de cisplatina, foi possível observar uma relação dose-efeito (ou seja, correlacionar o aumento da dose administrada com a diminuição da massa tumoral), porém, nos testes preliminares da viabilidade da medula óssea, não foi possível notar efeito mielossupressor das doses de cisplatina empregadas neste experimento.

Por outro lado, é relevante ressaltar que o tumor sólido de Ehrlich, apesar de apresentar as dificuldades supracitadas, se mostrou uma ferramenta de estudo interessante, de relativa facilidade de padronização e 
quantificação do crescimento; além disso, foi possível notar a relativa acessibilidade de análise em relação à regressão do tecido tumoral.

Isso posto, optou-se pelo o uso da forma ascítica do tumor de Ehrlich, uma vez que este modelo experimental possui certas vantagens como: fácil manipulação, simplicidade na padronização do número de células tumorais a serem inoculadas em cada animal, quantificação do crescimento tumoral e, principalmente, facilidade de acesso à "massa" tumoral (uma vez que esta encontra-se no peritônio do animal).

No Experimento 2 buscou-se estabelecer a quantidade mais adequada de células tumorais ascíticas de Ehrlich a ser inoculada nos camundongos da linhagem C57BI/6, empregando-se para isto a análise da curva de sobrevida. Assim, procurou-se determinar uma quantidade de células tumorais inoculadas que não causasse a morte de forma aguda nos camundongos, ou que comprometesse as análises dos possíveis efeitos antineoplásicos do alcalóide ou do extrato da $I$. carnea. Ou seja, era necessário encontrar a quantidade de células tumorais inoculadas que apresentasse agressividade consistente, porém não levasse a óbito o hospedeiro durante o período experimental (12 dias experimentais, de acordo com o protocolo aqui proposto). Além disso, a quantidade de células tumorais inoculadas deveria permitir que, ao final do período experimental, houvesse um volume ascítico suficiente para posterior coleta e análise, para o estudo dos possíveis efeitos antineoplásicos das substâncias aqui estudadas. 
Os resultados do Experimento 2 mostraram que, para a indução do tumor ascítico de Ehrich em camundongos C57Bl/6, a concentração de $2 \times 10^{7}$ células/animal foi a mais adequada para a obtenção dos objetivos supracitados.

Com o intuito de dar continuidade aos objetivos inicialmente propostos, foi necessário estabelecer a dose de cisplatina mais adequada para a administração em camundongos C57BI/6 portadores do tumor ascítico de Ehrlich. Vale salientar que existem poucos trabalhos na literatura que estudam a relação deste antineoplásico com o tumor ascítico de Ehrlich.

Assim, no Experimento 3 foram empregadas as doses de 1,0; 2,0 e $3,0 \mathrm{mg} / \mathrm{kg}$, com objetivo de encontrar um ponto de equilíbrio entre 0 tratamento antineoplásico do tumor ascítico de Ehrlich e a mielossupressão dos animais tratados. Estas doses de cisplatina foram avaliadas em relação à sobrevida dos animais e às principais características tumorais.

Nesse experimento, considerando a viabilidade de medula óssea, foi possível notar que as doses de cisplatina utilizadas foram eficazes na promoção da mielossupressão desejada, porém estas mesmas doses também apresentaram grande atividade antineoplásica (evento não desejado). De fato, a maior dose da cisplatina $(3 \mathrm{mg} / \mathrm{kg})$ reduziu em $100 \%$ o número de células tumorais, a dose intermediária reduziu em $80 \%$ e a menor dose levou à redução da celularidade tumoral de cerca 75\% (Tabela 9 e Figura 8). 
Apesar destas doses de cisplatina apresentarem algumas características desejáveis, como promover a mielossupressão (desejável neste trabalho), concluiu-se que tais doses seriam impraticáveis para o protocolo proposto, pois apenas a administração da cisplatina, sem estar associada com a suainsonina ou com o RAF da I. carnea, manifestou muita atividade antineoplásica, o que dificultaria a percepção de prováveis efeitos sinérgicos entre a suainsonina ou o RAF. Portanto, seria desejável uma dose de cisplatina que causasse redução de, no máximo, 50\% das células tumorais.

Desta forma, foi realizado o Experimento 4, no qual foram empregadas doses menores de cisplatina $(0,25 ; 0,5$ e $0,75 \mathrm{mg} / \mathrm{kg})$. Estas doses foram capazes de promover moderado efeito antineoplásico, permitindo detectar, assim, possíveis efeitos antineoplásicos da suainsonina ou do RAF, quando administrados em associação com a cisplatina. A partir dos resultados obtidos neste experimento, optou-se pelo o uso da menor dose de cisplatina $(0,25 \mathrm{mg} / \mathrm{kg})$ nas próximas etapas experimentais, pois esta dose promoveu diminuição de aproximadamente $46 \%$ da celularidade total do tumor. Tal fato permitiria a observação dos possíveis efeitos antineoplásicos das substâncias aqui estudadas (suainsonina e RAF da $I$. carnea). No entanto, quando à celularidade da medula óssea analisada, foi observado que as três doses de cisplatina foram incapazes de promover mielossupressão. Sendo assim, decidiu-se pela realização de experimentos separados: um que avaliasse a atividade antineoplásica da suainsonina e 
do RAF da I. carnea; e outro que avaliasse as possíveis atividades mieloprotetoras destas substâncias.

No Experimento 5 foi estudada a curva de sobrevida de camundongos C57Bl/6 inoculados com o tumor ascítico de Ehrlich (na concentração de $2 \times 10^{7}$ células tumorais/animal) e tratados com a suainsonina ou o RAF da I. carnea, administrados isoladamente ou em associação com cisplatina, na dose de $0,25 \mathrm{mg} / \mathrm{kg}$.

Vale ressaltar, neste momento, que devido às particularidades da freqüência e das vias de administração (gavage e via intraperitoneal), todos os animais dos diferentes grupos foram submetidos às mesmas manipulações, a fim de excluir estas variáveis. É importante destacar que no Experimento 2 a média de sobrevida dos animais inoculados com $2 \times 10^{7}$ células do tumor ascítico de Ehrlich foi de 16 dias, enquanto no Experimento 5 a média de sobrevida nos animais do grupo controle foi de 12,5 dias, mesmo estes animiais sendo inoculados com uma concentração idêntica de células neoplásicas. Esse achado pode ser atribuído, ao menos em parte, ao estresse da manipulação e da administração diária sofrido por estes animais.

Os resultados do Experimento $\mathbf{5}$ mostraram que a administração associada de suainsonina com cisplatina aumentou a sobrevida dos camundongos portadores do tumor ascítico de Ehrlich $(p<0,01)$, quando comparados aos camundongos do grupo controle. Além disso, é importante mencionar que se observou tendência de aumento da sobrevida nos animais tratados apenas com cisplatina $(p=0,0573)$ e daqueles tratados com 
a associação de cisplatina com o RAF $(p=0,0595)$. Por outro lado, os animais tratados apenas com suainsonina ou o RAF da I. carnea não apresentaram qualquer efeito benéfico (estatisticamente perceptível) considerando a sobrevida, quando comparados aos animais do grupo controle.

Outro resultado relevante obtido neste experimento foi a presença de diferença estatística entre o grupo tratado apenas com o antineoplásico, a cisplatina (Cis), e o grupo tratado com a combinação deste com o princípio ativo da I. carnea, a suainsonina (CisSw). Os animais que receberam a associação apresentaram aumento estatiticamente significante na sobrevida $(p<0,05)$, quando comparados aos animais tratados apenas com o quimioterápico tradicional, a cisplatina.

Estes resultados apontam a existência de diferença entre os grupos supracitados, indicando que os animais tratados pela assossiação dos princípios ativos (suainsonina/cisplatina) apresentaram maior eficiência no combate ao crescimento tumoral, uma vez que estes camundongos tiveram aumento significante na sobrevida (não só quando comparados com os animais do grupo controle, mas também quando comparados aos camundongos pertencentes ao grupo tratado apenas com a cisplatina). Assim, pode-se sugerir que o alcalóide da l. carnea, a suainsonina, e a cisplatina, quando assossiadas, possuem alguma atividade sinérgica, agindo ambas de maneira deletéria sobre células neoplásicas, já que esta combinação aumentou a sobrevida dos animais. 
Hamaguchi et al. (2007) apresentaram dados que reforçam a atuação da suainsonina como uma droga sinérgica em tratamentos antitumorais, neste caso a droga estudada foi o 5-fluorouracil, mostrando que as células neoplásicas tratadas com a suainsonina apresentaram alterações nos $\mathrm{N}$ glicanos, as quais não permitiram a aquisição de resistência destas células tumorais ao antineoplásico. Estes resultados corroboram com aos achados de HISS, 2007, que mostrou que a tunicamicina (droga que possui como mecanismo de ação a alteração dos N-glicanos) também apresentou ação sinérgica ao impedir a resistência de células tumorais a antineoplásicos.

Deve-se salientar que os animais tratados apenas com o alcalóide (SW) não apresentaram nenhum aumento de sobrevida quando comparados aos animais do grupo controle. Isso indica que tal princípio ativo, por si só, não possui qualquer efeito antineoplásico, nas condições experimentais propostas. $\mathrm{O}$ mesmo foi observado nos animais tratados com o RAF da I. carnea (RAF).

Com o intuito de evidenciar os efeitos antineoplásicos da suainsonina foi realizado o Experimento 6, que avaliou os efeitos de diferentes tratamentos (branco, controle, cisplatina, cisplatina/suainsonina, suainsonina, cisplatina/RAF, e RAF da I. carnea ) no crescimento das células do tumor ascítico de Erhlich. Os parâmetros utilizados para a mensuração do crescimento tumoral foram o volume tumoral, o número de céluas tumorais $/ \mathrm{mL}$ de líquido tumoral e a contagem total de células tumorais. 
Os resultados mostraram redução do volume médio tumoral apenas nos camundongos tratados com cisplatina $(7,70 \mathrm{~mL})$ ou com a associação desta com a suainsonina $(5,18 \mathrm{~mL})$, quando comparados com os camundongos do grupo controle $(14,21 \mathrm{~mL})$, evidenciando a menor média de volume tumoral obtida pelos animais pertencentes ao grupo CisSw (Tabela 17 e Figura 28).

Em relação às células tumorais $/ \mathrm{mL}$, observou-se que apenas os animais tratados com cisplatina apresentaram redução significante deste parâmetro, quando comparados a camundongos do grupo controle (Tabela 17 e Figura 29). Contudo, esse achado não deve ser considerado isoladamente. Essa questão pode ser exemplificada da seguinte maneira: um baixo número de células $/ \mathrm{mL}$, quando avaliado separadamente do contexto, representaria uma pequena taxa de crescimento tumoral. Contudo, quando se analisa o todo, isso não significa que o animal esteja em condições privilegiadas, pois outros fatores influenciam no crescimento do tumor ascítico de Ehrlich, como o volume total do líquido ascítico e a viabilidade das células tumorais.

Um exemplo dessa situação, observada nesse experimento, foi a de um animal do grupo controle que apresentava $12,5 \times 10^{7}$ células $/ \mathrm{mL}$ (valor baixo de células $/ \mathrm{mL}$ ), porém este mesmo animal possuía um volume total de líquido tumoral ascítico em seu peritônio de 15,8mL. Nesta condição, o camundongo encontrava-se próximo do óbito, com dispnéia em função da grande quantidade de líquido em seu abdomen, dificultando sua respiração por diminuir a contração diafragmática. Por outro lado, analisando 
isoladamente outro animal, do grupo CisSw, que apresentava $38,5 \times 10^{7}$ células $/ \mathrm{mL}$, acreditaria-se que este possuia um crescimento tumoral muito mais elevado do que o do camundongo do grupo controle. Entretanto, o animal do grupo experimental apresentava-se clinicamente normal, com um volume tumoral de apenas $0,7 \mathrm{~mL}$. Esses exemplos mostram a importância de se avaliar a celularidade tumoral.

A celularidade tumoral total mostrou que os camundongos pertencentes aos grupos Cis e CisSw apresentaram redução significante deste parâmetro quando comparados aos animais do grupo controle (Tabela 17 e Figura 30). É importante salientar que os animais tratados com cisplatina associada ao RAF da I. carnea (grupo CisRAF) apresentaram tendência de diminuição do número total de células tumorais. Além disso, observou-se maior redução significante desse parâmetro nos animais tratados com a associação cisplatina/suainsonina (grupo CisSW - $p<0,001$ ) do que a redução observada nos camundongos tratados apenas com a cisplatina (grupo Cis - $p<0,01$ ), ambos comparados aos animais do grupo controle. Estes resultados corroboram os resultados anteriores, referentes ao Experimento 5, sugerindo, novamente, que a associação destes princípios combate de maneira mais eficaz o crescimento tumoral.

A análise do número de células viáveis é um importante parâmetro, relacionado ao crescimento tumoral, sendo que através desta análise podese indicar o "vigor" tumoral. Ou seja, quanto mais células viáveis em uma população tumoral, maior a capacidade de crescimento deste tumor. Quando o número total de células tumorais viáveis foi comparado entre os 
diferentes grupos experimentais e o grupo controle, notou-se que todos os grupos tratados com cisplatina (Cis, CisSW, e CisRAF) apresentaram redução deste parâmetro. Portanto, esses tratamentos tiveram a capacidade de reduzir o potencial de crescimento do tumor ascítico de Ehrlich. É conveniente destacar que em uma escala decrescente na redução das células viáveis, observou-se CisRAF>Cis>CisSW, indicando que os animais tratados com a associação da cisplatina/suainsonina apresentaram menor número de células viáveis. Isto sugere que este último tratamento apresenta maior eficácia na redução do "vigor" tumoral em relação aos outros.

O crescimento tumoral está relacionado a um balanço somatório resultante entre a proliferação e a morte das células tumorais (FARIAS et al, 2005). A porcentagem de células viáveis/inviáveis na população total de células tumorais nos diferentes grupos experimentais também foi estudada (Experimento 6). Comparou-se a porcentagem de células inviáveis dos grupos controle, Cis e CisSW (Tabela 18 e Figura 33), e foi possível observar que apenas os camundongos tratados com cisplatina apresentaram redução significativa deste parâmetro, quando comparados aos animais do grupo controle. Tal fato não foi observado no grupo CisSW.

Este resultado mostra que os camundongos do grupo CissW apresentaram maior número de células inviáveis e, portanto, uma maior redução do poder efetivo de crescimento tumoral, superando os animais do grupo Cis. Para esclarecer esta análise, é relevante comentar que quando os animais do grupo Cis apresentaram uma redução na porcentagem de 
células inviáveis (comparado aos camundongos do grupo controle), apresentaram um aumento na porcentagem de células tumorais vivas (viáveis). Ou seja, os animais tratados apenas com a cisplatina possuíam menor eficiência em reduzir o crescimento tumoral (percentualmente), quando comparados aos animais do grupo controle e do grupo CisSW.

É importante comentar a elevada proporção de células inviáveis $(15,88 \%)$ nos animais do grupo controle, fato que, a priori, seria estranho, uma vez que estes camundongos não foram expostos a qualquer tratamento. Na realidade, este fato pode ser atribuído ao elevado número de células tumorais presentes no líquido ascítico destes animais, com conseqüente aumento na competitividade entre estas células por nutrientes (oxigênio, carboidratos, aminoácidos e lipídios), aumentando, assim, a taxa de morte celular por "inanição". Estes achados corroboram com os estudos desenvolvidos por Silva et al. (2006).

Em posse destes resultados, empregou-se a citometria de fluxo para avaliar melhor tais achados. Esta técnica permitiu examinar quantativamente em qual fase do ciclo celular as células tumorais se encontravam, além de revelar quantas células tumorais estavam sofrendo apoptose.

De maneira simples, o ciclo celular pode ser dividido em três fases características: "G0/G1" - período de crescimento celular; "S" - fase de duplicação do material genético e "G2/M" - novo período de crescimento celular e a mitose propriamente dita (MALUMBRES; BARBACID, 2001). Já 
a apoptose pode ser definida como a morte celular não seguida de autólise (SARASTE; PULKKI, 2000).

A partir destas análises, pode-se observar que os animais do grupo controle apresentavam histogramas do ciclo celular caracterizados pela presença de um amplo pico de células na fase G0/G1 e picos relevantes de células tumorais na fase G2/M e em apoptose - Figura 34. Foi possível também observar efeitos deletérios evidentes sobre o ciclo celular nos grupos Cis (fato desejado, uma vez que este grupo tem um papel de controle positivo) e CisSW, com aumento do número de células em apoptose.

Os histogramas do ciclo celular dos camundongos tratados com a cisplatina foram caracterizados pela presença de um assentuado pico de células em apoptose e discretos picos nas fases G0/G1 e G2/M. Estes dados demonstram que a cisplatina teve a capacidade de causar morte celular, ou seja, teve uma função citotóxica, e não simplesmente cessou o ciclo celular; este mecanismo é comum a outros tipos de antineoplásicos empregados na terapia do câncer. O aumento de apoptose causado pela cisplatina também foi relatado por vários autores (EASTMAN, 1990; EASTMAN ; BARRY, 1992; LIANG; ULYATT, 1998; WANG et al., 2006).

Em particular, devem ser destacados os dados encontrados nos histogramas do ciclo celular dos camundongos tratados com a associação cisplatina/suainsonina (CisSW). Esses histogramas foram caracterizados pela presença de um grande pico de células em apoptose, quando 
comparado a todos os demais grupos, inclusive o grupo Cis, bem como picos muito pequenos nas demais fases do ciclo celular (G0/G1, S e G2/M).

Para averiguar melhor esta relação entre os tratamentos e os ciclos celulares, avaliou-se a porcentagem de células em apoptose em relação ao número total de células presentes no ciclo. Assim, notou-se que todos os animais que receberam cisplatina (grupos Cis, CisSW e CisRAF) apresentaram um aumento significante na porcetagem de células apoptóticas (Tabela 19 e Figura 36). Ressalte-se a existência de diferença estatística entre os grupos Cis e CisSW $(p<0,001)$ e do grupo CisRAF $(p<0,05)$, quando comparados aos grupo controle. É relevante salientar que a médias de células tumorais em apoptose do grupo CisSw (83,55\%) foi maior do que a dos animais tratados apenas com a cisplatina $(67,15 \%)$; os animais do grupo CisRAF apresentaram em média 45,93\% de células em apoptose. A título de comparação, a média de células tumorais em apoptose nos animais do grupo controle foi de 17,31\%. Estes dados são relevantes, uma vez que na última década ficou evidente que a apoptose tem um papel determinante na carcinogênese, no crescimento tumoral e na agressividade do câncer. A taxa de crescimento tumoral é resultado não apenas dos níveis de proliferação, mas também de morte celular (DE JONG et al., 2000).

Notou-se também que todos os animais que receberam cisplatina (grupos Cis, CisSw e CisRAF) apresentaram diminuição significante na porcetagem de células na fase G0/G1. Deve ser ressaltada a existência de diferença estatística entre os grupos Cis e CisSW $(p<0,001)$ em relação ao 
grupo CisRAF $(p<0,05)$, quando comparados aos grupo controle, mostrando que os camundongos pertencentes ao grupo CisSW e Cis apresentaram maior eficiência em diminuir o número de células no começo do ciclo celular do que aqueles tratados com a associação de cisplatina e o RAF da $I$. carnea.

Estes resultados também foram observados quando se avaliou a porcentagem de células na fase $\mathrm{S}$ do ciclo celular. Os animais pertencentes aos grupos Cis e CisSW apresentaram diminuição significante na porcetagem de células nesta fase do ciclo. Houve diferença estatística entre os grupos Cis $(p<0,01)$ e CisSW $(p<0,001)$, evidenciando que os camundongos tratados com a associação cisplatina/suainsonina apresentaram maior eficiência em diminuir o número de células na fase de duplicação de material genético do que àqueles tratados apenas com cisplatina.

A fase do ciclo G2/M também foi analisada, dada a importância desta fase para o crescimento tumoral, uma vez que durante esta etapa do ciclo ocorre a duplicação celular (mitose) propriamente dita. Esta análise revelou que tanto os animais pertencentes ao grupo Cis quanto os integrantes do grupo CisSW apresentaram diminuição significante na porcentagem de células em G2/M, ou seja, diminuíram o número de células que completariam a mitose. Novamente, houve diminuição mais significante na proporção das células em G2/M dos camundongos do grupo CisSW $(p<0,01)$, do que daquelas dos animais do grupo $\operatorname{Cis}(p<0,05)$, em relação ao grupo controle (Tabela 19 e Figura 39). 
O fato dos animais tratados com a associação da cisplatina com a suainsonina apresentarem resultados melhores (em relação à sobrevida e ao crescimento tumoral) do que os camundongos tratados com estes princípios isoladamente apontam para um possível sinergismo estre estas drogas. Por isso, é importante discutir os mecanismos de ação da cisplatina.

Este fármaco liga-se ao DNA, formando adutos, o que causa alterações na topologia da dupla hélice do DNA, atraindo grupos de alta mobilidade e outras proteínas (JORDAN; CARMO-FONSECA, 2000). Apesar de o DNA ser, aparentemente, o alvo principal da cisplatina, apenas 1\% da droga intracelular reage com o DNA nuclear (MANDIC et al., 2003; WANG; LIPPARD, 2005). Os precisos mecanismos de ação da cisplatina continuam incertos, uma vez que a maior parte da droga fica livre no ambiente celular, interagindo com componentes nucleares e com outras moléculas, como proteínas (CULLEN et al., 2007). Estes dados sugerem que efeitos farmacológicos e toxicológicos podem estar envolvidos com a inibição de certas enzimas celulares pela cisplatina; algumas enzimas já foram identificadas com alvos desta droga, entre elas a DNA polimerase (DUMAN et al., 1999), as caspases 3 e 8 (SHIN et al., 2005) e a topoisomerase II (HASINOFF et al., 2005). Além disso, Carminati (2005), observou que a cisplatina atua em genes relacionados com o metabolismo de importantes organelas celulares como o retículo endoplasmático e o complexo de Golgi.

Os achados sangüíneos (análise do hemograma e a avaliação bioquímica) avaliados no presente estudo, não apresentaram resultados 
estatisticamente relevantes. Em relação às lâminas histológicas, foi possível observar achados interesssantes em todos os órgãos avaliados. No fígado, foi observado aumento no número de hepatócitos binucleados (principalmente nos animais tratados com cisplatina) e de células em mitose (muitas atípicas), e a presença de alguns hepatócitos com cario/citomegalia. Além disso, em alguns cortes histológicos foi possível notar a presença de células neoplásicas aderidas à cápsula do órgão e, em determinados casos, notou-se a existência de êmbolos neoplásicos em vasos do sitema portahepático.

Os animais do grupo branco e controle apresentaram lâminas renais dentro dos padrões da normalidade, porém os camundongos do grupo controle, em alguns cortes, apresentaram células neoplásicas aderidas à cápsula do órgão. Os animais tratados com cisplatina (Cis, CisSW e CisRAF) apresentaram discreta proteinúria em túbulos proximais, em algumas lâminas foi possível notar um discreto quadro de glomerulonefrite membranoproliferativa multifocal; estas lesões já foram descritas em estudos anteriores (KOPF-MAIER, 1986, 1988). Nos camundongos tratados apenas com a suainsonina não foi possível notar qualquer tipo de alteração histopatológica; já nos animais tratados apenas com o RAF da l. carnea, a única alteração observada foi um discreto espessamento na membrana basal.

Os baços dos camundongos do grupo branco apresentaram-se dentro dos padrões de normalidade (com a presença de raros megacariócitos), diferentemente daqueles dos animais do grupo controle, 
que mostraram quadros de discreta hemossiderose; já os animais tratados com cisplatina apresentaram aumento do quadro de hemossiderose e do número de megacariócitos.

Os dados obtidos no Experimento 6, tomados em conjunto, mostraram que a associação de cisplatina com suainsonina afetou significativamente o crescimento do tumor ascítico de Ehrlich, uma vez que houve redução do volume tumoral, do número total de células presentes no líquido ascítico e da proporção de células viáveis (aumentanto a porcentagem de células inviáveis), bem como aumento do número de células em apoptose. Além disso, ocorreu uma diminuição muito significante do número de células no ciclo celular. Estes dados sugerem a existência de sinergismo entre cisplatina e suainsonina, uma vez que quando a cisplatina foi administrada isoladamente estes efeitos foram menores, e quando os animais tratados foram tratados apenas com a suainsonina não houve qualquer melhora nos índices aqui analisados.

Trabalhos relatam que a administração de suainsonina a camundongos expostos ou não a agentes mielossupressores, como radiação e antineoplásicos (OREDIPE et al., 1991, 2003a,b), proporciona um aumento na atividade proliferativa de células da medula óssea, devolvendo a esse órgão sua celularidade característica, sendo sugerido por estes autores seu uso futuro como medicamento naqueles pacientes sob terapia antineoplásica

Com o objetivo de vislumbrar os possíveis efeitos mieloprotetores da suainsonina e tendo em vista a impossibilidade de realizar lesão medular 
com a dose de 0,25mg/kg (Experimento 4) optou-se por usar uma dose de cisplatina superior às anteriores testadas neste estudo: $5 \mathrm{mg} / \mathrm{kg}$.

Foi avaliado também se haveria diferenças na celularidade de medula óssea das principais linhagens de camundongos existentes em nosso biotério (Experimento 7). Os resultados obtidos nesta primeira etapa do experimento constataram que não existem diferenças de celularidade da medula óssea entre as linhagens estudadas. Sendo assim, optou-se pelo uso dos camundongos da linhagem C57BI/6, uma vez que esta linhagem tem sido utilizada em outros experimentos e também devido à facilidade de manejo.

A segunda etapa deste experimento avaliou a celularidade da medula óssea e esplênica de camundongos C57BI/6 inoculados com o tumor ascítico de Ehrlich tratados com suainsonina, concomitantemente ou não com a cisplatina, na dose de $5 \mathrm{mg} / \mathrm{kg}$. Em relação ao crescimeto tumoral, todos os animais tratados com a cisplatina (grupos Cis e CisSW) não desenvolveram o tumor ascítico de Ehrlich, corroborando com os dados obtidos no Experimento 3, que mostrou que doses superiores a $3 \mathrm{mg} / \mathrm{kg}$ são capazes de reduzir $100 \%$ das células tumorais. Os camundongos do grupo controle e os tratados apenas com a suainsonina desenvolveram o tumor sem qualquer alteração perceptível, concordando com os experimentos anteriores.

A celularidade da medula óssea, neste experimento não revelou qualquer diferença estatítica entre os grupos experimetais (Cis, CisSW e 
SW) quando comparados aos grupos controle e branco, contrário a estudos anteriores (OREDIPE, 1991, 2003a,b; OLDEN, 1991; KLEIN, 1999).

A análise esplênica mostrou uma redução significante do peso deste órgão nos animais tratados apenas com o antineoplásico (Cis) quando comparados aos animais do grupo branco. Porém, quando a celularidae total deste órgão foi estudada, observou-se que os animais pertencentes ao CisSW apresentaram uma redução significante da celularidade esplênica ao serem comparados aos animais do grupo controle. Estes dados corroboram com estudos que avaliavam a toxicidade da suainsoninade feitos por outros autores (DE BALOGH, 1999; STEGELMEIER, 1998b), porém os resultados encontrados neste experimento foram mais moderados, fato explicado principalmente pelas diferenças relacionadas ao tempo de exposição, doses, modelo experimental e via de administração.

Finalizando, os resultados tomados em conjunto mostraram que a suainsonia possui, nas condições experimetais propostas, sinergismo com a cisplatina, aumentando a ação antineoplásica desta droga. De fato, quando administrada isoladamente, a suainsonina não apressentou qualquer efeito sobre o crescimento tumoral; no entanto, a associação suainsonina/cisplatina apresentou resultados mais expressivos do que quando os animais foram tratados apenas com o antineoplásico. Além disso, os animais tratados por via oral (gavage) com o resíduo aquoso final da $I$. carnea não apresentaram qualquer melhora em relação ao desenvolvimento tumoral, mesmo quando tratados simultaneamente com a cisplatina. Ainda, os experimentos realizados não foram capazes de revelar 
a existência de mieloproteção por parte da suainsonina frente à agressão causada pela cisplatina. 


\section{CONCLUSÕES}




\section{CONCLUSÕES}

$\checkmark$ A avaliação do crescimento tumoral foi realizada de maneira mais simples e eficiente nos animais inoculados com a forma ascítica do tumor de Ehrlich, quando comparados aos animias inoculados com a forma sólida do mesmo tumor.

$\checkmark$ A dose de inoculação ideal do tumor ascítico de Ehrlich em camundongos da linhagem C57Bl/6, nas condições experimentais propostas, foi a de $2 \times 10^{7}$ células tumorais.

$\checkmark$ A dose de $0,25 \mathrm{mg} / \mathrm{kg}$ de cisplatina mostrou-se a mais adequada para o protocolo aqui proposto, causando uma diminuição no crescimento do tumor ascítico de Ehrlich, porém, permitindo a análise do efeito de outras substâncias administradas em associação com este antineoplásico.

$\checkmark$ Os animais tratados concomitantemente com cisplatina $(0,25 \mathrm{mg} / \mathrm{kg})$ e suainsonina $(1 \mathrm{mg} / \mathrm{kg})$ apresentaram aumento significante na sobrevida, quando comparados aos camundongos dos grupo controle $(p<0,01)$ e àqueles tratados apenas com a cisplatina $(p<0,05)$. Os animais tratados com o resíduo aquoso final da $I$. carnea não apresentaram resultados significantes, nem quando o tratamento foi associado à cisplatina. $\mathrm{O}$ grupo tratado apenas com a suainsonina também não apresentou aumento na sobrevida. 
$\checkmark$ O tratamento de maior sucesso no combate ao crescimento do tumor ascítico de Ehrlich foi a associação entre cisplatina $(0,25 \mathrm{mg} / \mathrm{kg})$ e suainsonina (1mg/kg). Estes animais obtiveram reduções significantes em diversos parâmetros analisados: volume tumoral, número total de células tumorais, número total de células tumorais viáveis e porcentagem de células tumorais no ciclo celular. Os camundongos de outros grupos tratados com cisplatina (apenas cisplatina, ou cisplatina e resíduo aquoso final da I. carnea) também apresentaram redução no crescimento tumoral, porém com menor significância. Novamente, o tratamento com o resíduo aquoso final da I. carnea não apresentou resultados significantes (nem quando associado à cisplatina). O grupo tratado apenas com a suainsonina também não apresentou redução no crescimento tumoral.

$\checkmark$ A possível mieloproteção por parte do princípio ativo da I. carnea, a suainsonina, não foi observada nos experimentos deste trabalho, seguindo os protocolos aqui propostos. 


\section{REFERÊNCIAS}




\section{REFERÊNCIAS}

AUSTIN, D. F.; HUAMAN, Z. A synopsis of Ipomea (Convolvulaceae) in the Americas. Taxon, v. 45, p. 3-38,1996.

CARMINATI, P. O. Respostas celulares aos danos causado pelo antitumoral cisplatina em linhagens de fibroblastos humanos normais (MRC-5) e astrocítica (U343-MG-a). 2005. Dissertação (mestrado) Faculdade de Medicina de Ribeirão Preto. Ribeirão Preto, 2005.

CULLEN, K. J.; YANG, Z.; SCHUMAKER, L.; GUO, Z. Mitochondria as a critical target of the chemotherapeutic agent cisplatin in head and neck cancer. Journal of Bioenergetics and Biomembranes, v.39, p.43-50, 2007.

DAGLI, M. L. Z. Disseminação linfática do tumor de Ehrlich: estudo experimental. 1989. 148 f. Dissertação (mestrado em medicina veterinária) Faculdade de Medicina Veterinária e Zootecnia, Universidade de São Paulo, São Paulo, 1989.

DE BALOGH, K. I. M.; DIMANDE, A. P.; VAN DER LUGT, J. J.; MOLYNEUX, R. J.; NAUDÉ, T. W.; WELMAN, W. G. A lysossomal storage disease induced by Ipomoea carnea in goats in Mozambique. Journal of Veterinary Diagnostic Investigation, v. 11, p. 266-273, 1999.

DE JONG, J. S.; VAN DIEST; P. J.; BAAK, J. P. Number of apoptotic cells as a prognostic marker in invasive breast cancer. British Journal of Cancer. v. 82, n. 2, p. 368-373, 2000.

DENNIS, J. W.; KOCH, K.; YOUSEFI, S.; VANDERELST, I. Growth inhibition of human melanoma tumor xenografts in athymic nude mice by swainsonine. Cancer Research, v. 50, p. 1867-1872, 1990.

DNA CELL CYCLE ANALYSIS. DNA Cell Cycle Analysis on BD FACSCanto II Cytometers Online Course. Disponível no site:

http://www.bdbiosciences.com/immunocytometry_systems/support/training/d na_canto2_course/> 
DORLING, P. R.; HUXTABLE, C. R.; VOGUEL, P. Lysossomal storage in Swainsona spp. toxicosis: an induced mannosidosis. Neuropathology and Applied Neurobiology, v. 4, p. 285-295, 1978.

DUMAN, R. K.; HEATH, R. T.; BOSE, R. N. Inhibition of Escherichia coli DNA polymerase I by the anticancer drug cis-diaminedichloroplatinum(II): what roles do polymerases play in cisplatin-induced cytotoxicity? FEBS Letters, v. 455, p. 49-54, 1999.

EHRLICH, P. Experimentelle carcinomstudien an Mäusen. Arb Inst Exp Ther Frankfurt, v. 1, p. 78-80, 1906.

ELBEIN, A. D. The effects of plant indolizidine alkaloids and related compounds in glycoprotein processing. In: JAMES, L. F.; ELBEIN, A. D.; MOLYNEUX, R. J.; WARREN, C. D. (Ed.) Swainsonine and related glycosidase inhibitors. Ames: lowa University Press,1989. p. 155-187.

FARIAS, R. E.; SOUZA, A. R.; AARESTRUP, F. M. Avaliação da apoptose no carcinoma ductal da mama: associação com graus histológicos e fatores prognósticos. Revista Brasileira de Cancerologia, v. 51, n. 3, p. 209-218, 2005.

GANDARA, D. R.; MANSOUR, R.; WOLD, H.; GEORGE, C. Dose-limiting myelosuppression associated with high-dose cisplatin $(200 \mathrm{mg} / \mathrm{m} 2)$ in hyper tonic saline. Cancer treatment reports, v. 70, p. 820-821, 1986.

GARDINER, M. R.; ROYCE, R.; OLDROY, B. Ipomoea muelleri intoxication of sheep in Western Australia. British Veterinary Journal, v. 121, p. 272277, 1965.

GENTILE, J. M.; LOHMAN, P. H. M.; FERGUSON, L. R.

Antimutagenesis/Anticarcinogenesis 2001: mechanistic studies. Mutation Research, v. 480, p. 1-7, 2001.

GHOSH, S.; MAITY, P. Vascular endothelial growth factor immunoneutralization in combination with cisplatin reduces EAC tumor growth, International Immunopharmacology, v. 6, p. 1550-1559, 2006. 
GONÇALVES, M. L. Convolvulaceae-Custaceae. In: LAUNERT, E. (Ed.). Flora zambesiaca. London: Flora Zambesiaca Managing Committee, 1987. v. 8, p. 117-118.

GÓRNIAK, S. L. Hipnoanalgésicos e Neuroleptoanalgesia; In SPINOSA, H. S.; GÓRNIAK, S. L.; BERNARDI, M. M.; Farmacologia aplicada à medicina veterinária. Rio de Janeiro: Guanabara Koogan; 2007. p. 177184.

GRINGERI, A.; KENG, P. C.; HORCH R. F.; Diethyldithiocarbamate Inhibition of Murine Bone Marrow Toxicity Caused by cw-

Diamminedichloroplatinum(II) or Diammine-(I,Icyclobutanedicarboxylato)platinum(II). Cancer Research, v. 48, p.57085712, 1988.

\section{GUERRA, J. L. Aspecto do processo inflamátorio em camundongos} portadores de tumor de Ehrlich. 1983. Tese (Doutorado) - Faculdade de Medicina Veterinária e Zootecnia, Universidade de São Paulo, São Paulo,1983.

HAMAGUCHI, J.; NAKAGAWA, H.; TAKAHASHI, M.; KUDO, T.; KAMIYAMA, N.; SUN, B.; OSHIMA, T.; SATO, Y.; DEGUCHI, K.; TODO, S.; NISHIMURA, S. I. Swainsonine reduces 5-fluorouracil tolerance in the multistage resistance of colorectal cancer cells lines. Molecular Cancer, v. 6, n. 58, 2007.

HARRAP, K. R.; JONES, M.; WILKINSON, C. R.; CLINK, H. M.; SPARROW, S.; MITCHLEY, B. C. V.; CLARKE, S.; VEASEY, A. Antitumor, toxic, and biochemical properties of cisplatin and eight other platinum complexes.

In:Cisplatin: Current status and New Developments, PRESTAYKO, A. W.; CROOKE, S. T.; CARTER, S. K, Eds Academic Press, New York, 1980, p.193.

HASINOFF, B. B.; WU, X.; KROKHIN, O. V.; ENS, W.; STANDING, K. G; NITISS, J. L.; SIVARAM, T.; GIORGIANNI, A.; YANG, S.; JIANG, Y.

Biochemical and proteomics approaches to characterize topoisomerase Ila cysteines and DNA as targets responsible for for cisplatin-induced inhibition of topoisomerase Ila. Molecular Pharmacology, v. 67, p. 937-947, 2005. 
HISS, D. C.; GABRIELS, G. A.; FOLB, P. I. Combination of tunicamycin with anticancer drugs synergistically enhaces theis toxicity in multidrug-resistant human ovarian cystadenocarcinoma cells. Cancer Cell International, v.7, n 5, 2007.

HOCKING, D. C.; SOTTILE, J.; MCKEOWN-LONGO, P. J. Activation of distinct $\alpha_{5} \beta_{1}$-mediated signaling pathways by fibronectin's cell adhesion and matrix assemble domains. The Journal of Cell Biology, v. 141, p. 241-253, 1998.

HOHENE, F. C. Plantas e substâncias vegetais tóxicas e medicinais. $\mathbf{O}$ Estado de São Paulo, São Paulo, p. 32, 1939.

HUEZA, I. M.; DAGLI, M. L. Z.; GÓRNIAK, S. L. Toxic effects of prenatal Ipomoea carnea administration to rats. Veterinary and Human

Toxicology,. v. 45, p. 298-302, 2003.

HUEZA, I. M.; FONSECA, E. S. M.; PAULINO, C. P.; HARAGUCHI, M.; GÓRNIAK, S. L. Evaluation of immunomodulatory activity of Ipomoea carnea on peritoneal cells of rats. Journal of Ethnopharmacology, v. 87, p. 181186, 2003.

HUEZA, I. M.; GUERRA, J. L.; HARAGUCHI, M.; ASANO, N.; GÓRNIAK, S. $\mathrm{L}$. The role of alkaloids in Ipomoea carnea toxicosis: A study in rats.

Experimental and Toxicologic Pathology, v. 57, n. 1, p. 53-58, 2005.

HUMPHRIES, M. J.; MATSUMOTO, K.; WHITE, S. L.; OLDEN, K. Inhibition of experimental metastasis by castanospermine in mice: Blockage of two distinct stages of tumor colonization by oligosaccharide processing inhibitors. Cancer Research, v.46, p. 5215-5222, 1986b.

HUMPHRIES, M. J.; MATSUMOTO, K.; WHITE, S. L.; OLDEN, K. Oligosaccharide modification by swainsonine treatment inhibits pulmonary colonization by B16-F10 murine melanoma cells. Proceedings of the National Academy of Sciences of the United States of America, v. 83, p. 1752-1756, 1986a.

JORDAN, P.; CARMO-FONSECA M. Molecular machanisms involved in cisplatin cytotoxity. Cellular and Molecular Life Sciences, v. 57, n. 8-9, p. 1229-1239, 2000. 
KOPF-MAIER, P. Histologic and ultrastructural alterations of xenografted human colon adenocarcinoma after treatment with titanocene dichoride. Journal of Cancer Research and Clinical Oncology, v. 144, p. 250-258, 1988.

KOPF-MAIER, P.; FUNKE-KAISER, P. Organ toxicity of metallocene dichlorides. The effect of $\left(\mathrm{C}_{5} \mathrm{H}_{5}\right)_{2} \mathrm{Ti} \mathrm{Cl}_{2}$ and $\left(\mathrm{C}_{5} \mathrm{H}_{5}\right)_{2} \mathrm{Cl}_{2}$ on renal structure. Toxicology, v. 38, p. 81-90, 1986.

LATORRE, A. O.; HUEZA, I. M.; GÓRNIAK, S. L. Association of Ipomoea carnea and BCG reduces birth defects caused by cyclophosphamide in rats. Life Sciences, v. 80, n. 5, p. 430-435, 2007.

LORENZI, H. Plantas daninhas do Brasil: terrestres, aquáticas, parasitas, tóxicas e medicinais. 2. ed. Nova Odessa: Platarum. 1991. p. 125.

LUCCAS, S. R. R.; DAGLI, Z. M. L. Agentes antineoplásicos; In SPINOSA, H. S; GÓRNIAK, S. L.; BERNARDI, M. M.; Farmacologia aplicada à medicina veterinária. Rio de Janeiro: Guanabara Koogan, 2007. p. 177184.

MADY, E. A. Antitumor and biochemical effects of Echis coloratus crude venon on Ehrlich ascite carcinoma cells in vivo. Journal of Venomous Animals and Toxins, v. 8, p. 283-296, 2002.

MALUMBRES, M.; BARBACID, M. To cycle or not to cycle: a critical decision in cancer. Nature Reviews Cancer, v. 1, n. 3, p. 222-231, 2001.

MANDIC, A.; HANSSON, J.; LINDER, S.; SHOSHAN, M. C. Cisplatin induces endoplasmic reticulum stress and nucleus-independent apoptotic signaling. Journal of Biological Chemistry, v. 278, n. 11, p. 9100-9106, 2003.

MATOS, F. J. A. Efeitos psicotrópicos de plantas brasileiras. Ciência e Cultura, v. 35, p. 432-434, 1983.

MCKNIGHT, J. A. Principles of chemotherapy. Clinical Techniques in Small Animal Practice, v. 18, n. 2, p. 67-72, 2003. 
MOREMEN, K. W.; ROBBINS, P. W. Isolation, characterization, and expression of cDNA encoding murine $\alpha$-mannosidase II, a golgi enzyme that controls conversion of high mannose to complex N-glycans. Journal of Cell Biology, v. 115, p. 1521-1534, 1991.

OGILVIE, G. K. Chemotherapy and the surgery patient: Principles and recent advances. Clinical Techniques in Small Animal Practice, v. 13, n. 1, p. 22-32, 1998.

OLDEN, K.; BRETON, P.; GRZEGORZEWSKI, K.; YASUDA, Y.; GAUSE, B. L.; OREDIPE O. A.; NEWTON, S. A.; WHITE, S. L. The potential importance of swainsonine in therapy for cancers and immunology. Pharmacology \& Therapeutics, v. 50, n. 3, p. 285-290, 1991.

OREDIPE, O. A.; FURBERT-HARRIS, P. M.; GREEN, W. R.; WHITE, S. L.; OLDEN, K.; LANIYAN, I.; PARISH-GAUSE, D.; VAUGHN, T.; GRIFFIN, W. M.; SRIDHAR, R. Swainsonine stimulates bone marrow cell proliferation and differentiation in different strains of inbred mice. Pharmacological Research, v. 47, n. 1, p. 69-74, 2003.

OREDIPE, O. A.; FURBERT-HARRIS, P. M.; LANIYAN, I.; GREEN, W. R.; WHITE, S. L.; OLDEN, K.; PARISH-GAUSE, D.; VAUGHN, T.; GRIFFIN, W. M.; SRIDHAR, R. Enhanced proliferation of functionally competent bone marrow cells in different strains of mice treated with swainsonine.

International Immunopharmacology, v. 3, n. 3, p. 445-455, 2003.

OREDIPE, O. A.; WHITE, S. L.; GRZEGORZEWSKI, K.; GAUSE, B. L.; CHA, J. K.; MILES, V. A.; OLDEN, K. Protective effects of swainsonine on murine survival and bone marrow proliferation during cytotoxic chemotherapy. Journal of the National Cancer Institute, v. 83, n. 16, p. 1149-1156, 1991.

OZOLS, R. F.; CORDEN, B. J.; JACOB, J.; WESLEY, M. N.; OSTCHEGA, Y.; YOUNG, R. C. High-dose cisplatin in hypertonic saline. Annals of Internal Medicine, v. 100, p. 19-24, 1984.

PALERMO-NETO, J.; MASSOCO, C. O.; SOUZA, W. R. Effects of physical and psychological stressors on behavior, macrophage activity, and Ehrlich tumor growth. Brain, Behavior and Immunity, v. 17, p. 43-54, 2003. 
PANKOV, R.; YAMADA, K. M. Fibronectin at glance. Journal of Cell Science, v. 115, p. 3861-3863, 2002.

PRESTAYKO, A. W.; CROOKE S. T.; CARTER, S. K. Cisplatin: current status and new developments. New York: Academic Press, 1980. p. 193212.

ROSE, W. C.; SCHURIG, J. E.; HUFTALEN, J. B.; BRADNER, W. T. Antitumor activity and toxicity of cisplatin analogs. Cancer Treatment Reports, v. 66, p. 135-146, 1982.

SARASTE, A.; PULKKI, K. Morphologic and biochemical hallmarcks of apoptosis. Cardiovascular Research, v. 45, n. 3, p. 528-537, 2000.

SCHNEIDER, M. J.; UNGMACH, F. S.; BROQUIST, H. P.; HARRIS, T. M. (1S2R8R8aR)-1,2,8-trihydroxy-octahidroindolizidine (swainsonine), an $\alpha$ mannosidase inhibitor from rhizoctonia lebuminicola. Tetrahedron, v. 39, p. 29-32, 1983.

SCHWARZ, A.; GÓRNIAK, S. L.; BERNARDI, M. M.; DALGLI, M. L. Z.; SPINOSA, H. S. Effects of Ipomoea carnaea aqueous fraction intake by dams during pregnancy on the physical and neurobehavioral development rat offspring. Neurotoxicology and Teratology, v. 25, p. 615-626, 2003.

SEGURA, J. A.; BARBERO, L. G.; MARQUEZ, J. Ehrlich ascites tumour unbalances splanic cells populations and reduces responsiveness of $T$ cells to Staphylococcus aureus enterotoxin B stimulation. Immunology Letters, v. 74, p. 111-115, 2000.

SHIN, J. N.; SEO, Y. W.; KIM, M.; PARK, S. Y.; LEE, M. J.; LEE, B. R.; OH, J. W.; SEOL, D. W.; KIM, T. H. Cisplatin inactivation of caspases inhibits death ligand-induced cell death in vitro and fulminant liver damage in mice. Journal of Biological Chemistry, v. 280, p. 10509-10515, 2005.

SHUMAHER-HENRIQUE, B.; GÓRNIAK, S. L.; DALGLI, M. L. Z.; SPINOSA, H. S. Toxicity of Long- term Administrati of Ipomoea carnea to Growing Goats: Clinical, Biochemical, Haematological and Pathological Alterations. Veterinary Research Communications, v. 27, p. 311-319, 2003. 
SILVA, A. E. Efeito do hipotireoidismo no tumor de Ehrlich na deficiência ou suficiência dos esteróides sexuais femininos, 2003. Dissertação (mestrado em patologia) - Escola de Veterinária, Universidade Federal de Minas Gerais, Belo Horizonte, 2003.

SILVA, A. E.; SANTOS, F. G. A.; CASSALI, G. D. Marcadores de proliferação celular na avaliação do crescimento do tumor sólido e ascítico de Ehrlich. Arquivo Brasileiro de Medicina Veterinária e Zootecnia, v. 58, n. 4, p. 658-661, 2006.

SPECTOR, D. L; GOLDMAN, R. D; LEINWAND, L. A. Apoptosis assays. In: SPECTOR, D. L; GOLDMAN, R. D; LEINWAND, L Cells, a laboratory manual culture and biochemical analysis of cells. New York Cold Spring, 1998. v. 1, Chap. 15, p.24.

SRIGANTH, I. N. P.; PREMALATHA, B. Dietary curcumin with cisplatin administration modulates tumour marker indices in experimental librosarcoma. Pharmacological Research, v. 39, n. 3, p. 175-179, 1999.

SRILATHA, C. H.; GOPAL-NAIDU, N. R.; RAMA-RAO, P. Pathology of Ipomoea carnea toxicity in goats. Indian Journal of Animal Sciences, $v$. 67, p. 253-254, 1997.

STEGELMEIER, B. L.; JAMES, L. F.; PANTER, K. E.; GARDNER, D. R.; RALPHS, M. H.; PFISTER, J. A. Tissue swainsonine clearance in sheep chronically poisoned with locoweed (Oxytropis sericea), Journal of Animal Science, v. 76, p. 1140-1144, 1998.

STEGELMEIER, B. L.; SNYDER, P. D.; JAMES, L. F. PANTER, K. E.; MOLYNEUX, R. J., RALPHS, M. H.; PFISTER, J. A. The immunologic and toxic effects of locoweed (Astragalus lentiginosu) intoxiction in cattle. In: GARLAND, T. R.; BEILEY, M. R.; PANTER, K. E.; DORLING, P. R. (Ed.). Toxic plants and other natural toxicants. Wallingford Oxon: $C A B$ International, Oxon, 1998. p. 285-290.

STEWART, H. L. (Ed.). Transplantable and transmissible tumors of animals. Washington, D.C: Armed Fource Institute of Pathology, 1959. 378 p. 
TIRKEY, K.; YADAVA, K. P.; MANDAL, T. K. Effect of aqueus fraction of Ipomoea carnea on the haematological and biochemical parameters in goats. Indian Journal of Animal Sciences, v. 57, p. 1019-23, 1987

TOKARNIA, C. H.; DOBEREINER, J.; CANELLA, C. F. C. Estudo experimental sobre a toxidez do "canudo" (Ipomoea carnea Mart.) em ruminantes. Arquivos do Instituto de Biologia Animal, v. 3, p. 59-71, 1960.

TOKARNIA, C. H.; DOBEREINER, J.; PEIXOTO, P. V. Plantas que causam perturbações nervosas. In TOKARNIA, C. H. Plantas tóxicas do Brasil. Rio de Janeiro: Helianthus, 2000. p. 120-123.

TULLOCH, M. The genus Metarhizium. Transaction British Mycology Society, v. 66, p. 407-411, 1976.

TULSIANI, D. R.; BROQUIST, H. P.; JAMES, L. F.; TOUSTER, O. Production of hybrid glycoproteins and accumulation of oligosaccharides in the brain of sheep and pigs administered swaisonine or locoweed. Archives of Biochemistry Biophisics, v. 264, p. 607-617, 1988.

VAN KAMPEN, K. R.; JAMES, L. F. Sequencial development of cytoplasmatic vacuolation in tissues. Pathology Veterinary, v. 7, p. 503508, 1970.

VERÇOSA JUNIOR, D.; MELO, M. M.; CASSALI, G. D.; DANTAS-BARROS, A. M.; SILVA JUNIOR, P. G. P. Influência de Agaricus blazei Murril sobre o tumor sólido de Ehrlich e linfonodos poplíteos de camundongos. Arquivo Brasileiro de Medicina Veterinária e Zootecnia, v. 59, n. 1, p. 150-154, 2007.

VON HOFF, D. D.; SHILSKY, R.; REICHERT, C. M.; REDDICK R. L.; ROZENCWEIG, M.; YOUNG, R. C.; MUGGIA, F. M. Toxic effects of ci.vdichlorodiammineplatinum(II) in man. Cancer Treatment Reports, v. 63, p. 1527-1531, 1979.

WANG, D.; LIPPARD, S. J.; Cellular processing of platinum anticancer drugs. Nature Reviews Drug Discovery, v. 4, n. 4, p. 307-320, 2005. 
YAMADA K. M. Fibronectin peptides in cell migration and wound healing, The Journal of Clinical Investigation, v. 105, p. 1507-1509, 2000. 